PENGARUH LINGKUNGAN KERJA DAN MOTIVASI KERJA, TERHADAP KEPUASAN KERJA GURU DAN DAMPAKNYA PADA KINERJA GURU

TESIS

\title{
OLEH:
}

MOH. NASIR

NIM: 16710016

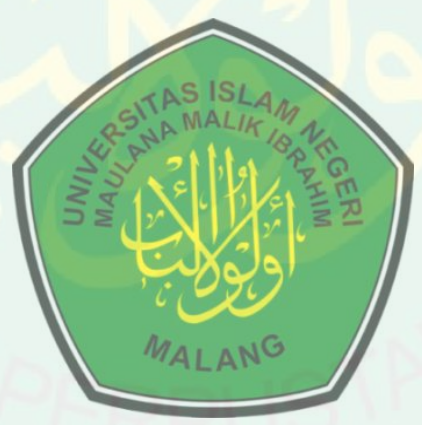

PROGRAM MAGISTER MANAJEMEN PENDIDIKAN ISLAM PASCASARJANA

UNIVERSITAS ISLAM NEGERI MAULANA MALIK IBRAHIM MALANG 


\section{PENGARUH LINGKUNGAN KERJA DAN MOTIVASI KERJA TERHADAP KEPUASAN KERJA DAN DAMPAKNYA PADA KINERJA GURU MADRASAH ALIYAH DI PULAU BAWEAN}

\section{TESIS}

\section{Diajukan Kepada :}

Pascasarjana

Universitas Islam Negeri Maulana Malik Ibrahim Malang

Untuk Memenuhi Beban Studi Pada

Program Magister Manajemen Pendidikan Islam

Pembimbing I

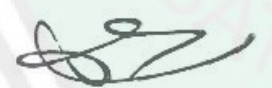

Dr. H. Munirul Abidin, M.Ag

NIP.19720420 2002121003
Oleh:

MOH. NASIR

NIM. 16710016

\section{PROGRAM MAGISTER MANAJEMEN PENDIDIKAN ISLAM PASCASARJANA \\ UNIVERSITAS ISLAM NEGERI MAULANA MALIK IBRAHIM \\ MALANG \\ 2018}




\section{LEMBAR PERSETUJUAN TESIS}

Nama

NIM

Program Studi

Judul Tesis

Pembimbing I

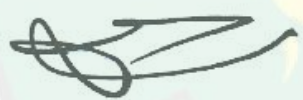

Dr. H. Munirul Abidin, M.Ag

NIP.19720420 2002121003
: Moh. Nasir

$: 16710016$

: Manajemen Pendidikan Islam

:Pengaruh Lingkungan Kerja, Dan Motivasi Kerja

Terhadap Kepuasan Kerja Guru Dan Dampaknya Pada

Kinerja Guru Madrasah Aliyah Di Pulau Bawean

Setelah diperiksa dan dilakukan perbaikan seperlunya, Tesis dengan judul sebagaimana di atas disetujui untuk diajukan ke sidang Ujian Tesis.

Pembimbing II

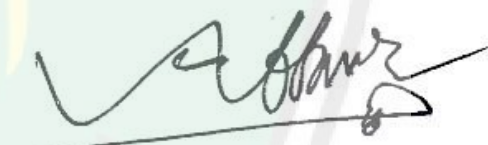

Dr. H. Abdul Bashith, M.Si

NIP.19761002 2003121003

Mengetahui,

Ketua Program Studi

Magister Manajemen Pendidikan Islam

Dr. H. Wahid Murni, M.Pd. Ak

NIP. 196903032000031002 


\section{LEMBAR PENGESAHAN TESIS}

Tesis dengan judul "Pengaruh Lingkungan Kerja Dan Motivasi Kerja Terhadap Kepuasan Kerja Guru Dan Dampaknya Pada Kinerja Guru Madrasah Aliyah Di Pulau Bawean" ini telah diuji dan dipertahankan di depan sidang dewan penguji pada tanggal 24 September 2018.

Dewan Penguji,

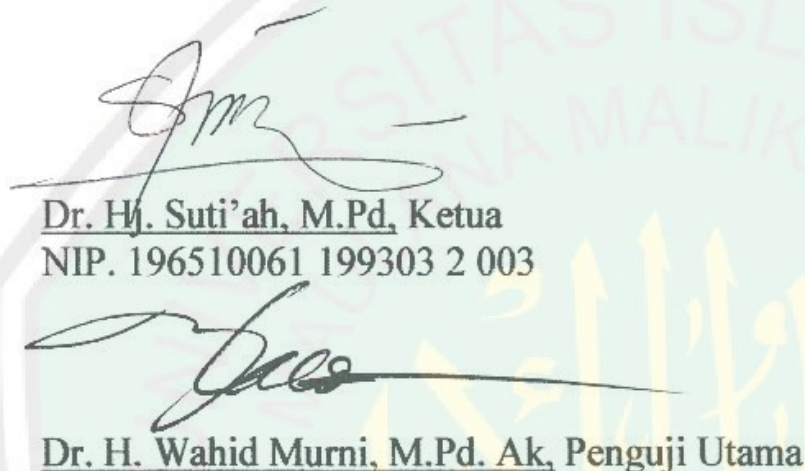

NIP. 196903032000031002

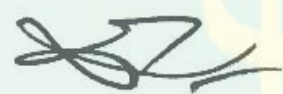

Dr. H. Munirul Abidin, M. Ag. Anggota

NIP. 197204202002121003

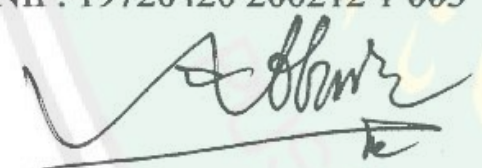

Dr. H. Abdul Bashith, M. Si. Anggota

NIP. 197610022003121003

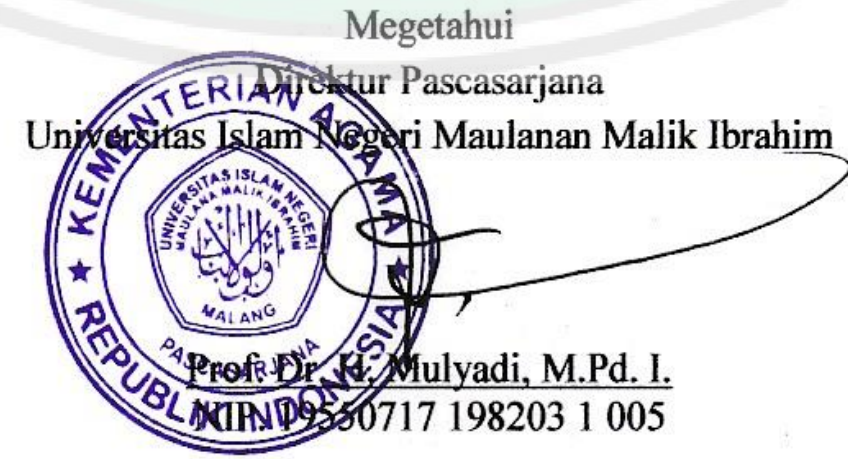




\section{PERNYATAAN KEASLIAN TULISAN}

Saya yang bertanda tangan dibawah ini:

$\begin{array}{ll}\text { Nama } & : \text { Moh. Nasir } \\ \text { NIM } & : 16710016\end{array}$

Program Studi : Manajemen Pendidikan Islam

Judul Penelitian : Pengaruh Lingkungan Kerja Dan Motivasi Kerja Terhadap Kepuasan Kerja Dan Dampaknya Pada Kinerja Guru Madrasah Aliyah Di Pulau Bawean

Menyatakan dengan sebenar-benarnya bahwa hasil penelitian saya ini tidak terdapat unsur-unsur penjiplakan karya penelitian atau karya ilmiah yang pernah dilakukan atau dibuat oleh orang lain, kecuali yang tertulis dikutip dalam naskah ini dan disebutkan dalam sumber kutipan dan daftar pustaka.

Apabila ternyata hasil penelitian ini terbukti terdapat unsur-unsur jiplakan maka saya bersedia untuk mempertanggung jawabkan, serta diproses sesuai peraturan yang berlaku.

Batu, 03 September 2018 Hormat Saya,

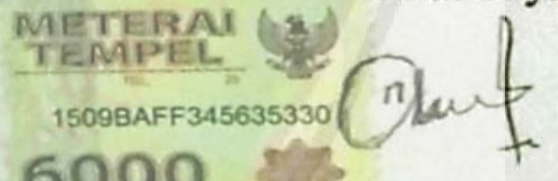

Moh. Nasir 16710016 


\section{HALAMAN MOTTO}

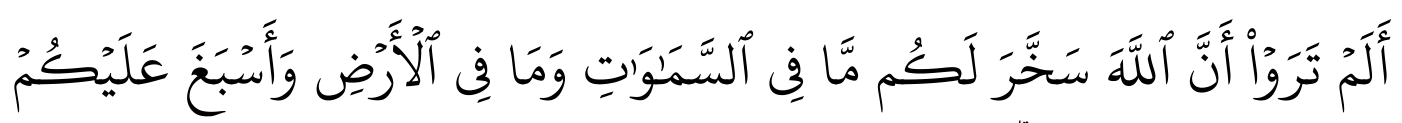

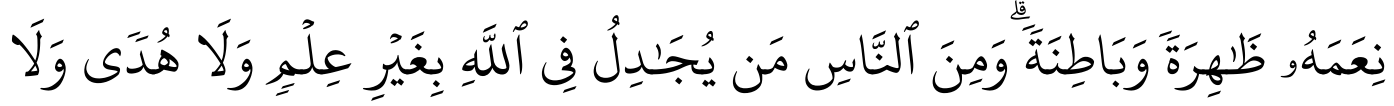

$$
\text { كِتَّب مِنِ }
$$

Tidakkah kamu perhatikan sesungguhnya Allah telah menundukkan untuk (kepentingan)mu apa yang di langit dan apa yang di bumi dan menyempurnakan untukmu nikmat-Nya lahir dan batin. Dan di antara manusia ada yang membantah tentang (keesaan) Allah tanpa ilmu pengetahuan atau petunjuk dan tanpa Kitab yang memberi penerangan. (Qs. Luqman: 20). ${ }^{1}$

\section{" wark hard in silence, let success make the naise"}

\footnotetext{
${ }^{1}$ Departemen agama Republik Indonesia, Al Qur'an Terjemah, Bandung: CV Penerbit
} Diponegoro,2009 


\section{HALAMAN PERSEMBAHAN}

Bismillahirrahmanirrahim.

Ya Allah.....

Terimah kasih atas nikmat dan rahmat-Mu yang agung ini, hari ini hamba bahagia, sebuah perjalanan yang panjang dan gelap ini perlahan-lahan telah engkau berikan secercah cahaya terang. Walupun hari esok masih penuh dengan teka-teki dan tanda tanya yang cukup besar, bahkan hamba sendiripun belum tahu jawabannya. Namun hamba tidak takut, ataupun menyerah, hamba akan terus berusaha dan berdoa pada-Mu.

Syukur Alhamdulillah..

Kini hamba tersenyum dalam iradat-Mu Kini hamba mengerti arti kesabaran dalam penantian, Kau menyimpan sejuta makna dan rahasia, sungguh berarti rahmat dan hikmah yang Kau beri.

Dengan kerendahan hati, beserta ridho Allah Swt, kupersembahkan salah satu karya terbesarku ini kepada.....

"Kakek dan Almarhumah nenek (H. Anwar \& Hj. Ainamah (Alm))"

Terima kasih atas do'a, bimbingan dan motivasi, kasih sayang selama ini yang tak pernah putus. Kerendahan hatinya dalam membimbingku, ketulusannya mengingatkan ku dalam kebaikan, Segalanya yang tak mungkin cukup ku ungkapkan hanya dalam tulisan sederhana ini".

“Bapak dan Mamak (Maidi \& Nasiyah)”

inilah kata-kata yang mewakili seluruh rasa, tiada yang dapat kuberi kan agar setara dengan pengorbananmu padaku, kasih sayangmu tak pernah bertepi, cintamu tiada berujung.

Kini.... sambutlah aku anakmu ini di depan pintu tempat dimana dulu anakmu mencium tanganmu dan terimalah keberhasilan berwujud gelar persembahanku ini sebagai bukti cinta dan tanda baktiku.....

"Adik-adikku (Moh. Rifki \& Khairul Anam)"

Terimah kasih atas dukungan, do 'a, dan semangatnya yang tiada putus"'

"Haslinda, Hasan, Hajri, Umi, Nafi, Habib, Liya, Bayu, Nindya, Najib, Nizara, Hadi,dan Ilul"

Terima kasih atas sumbangsih kalian selama proses penulisan Tesis ini”.

\section{Irfan S.Si, Zainal S.Si, Jauhar S.Farm, Bagus S.T, Iqbal S.Si,Muslim S.Kom Yusuf, serta teman-teman MPI angkatan 2016 dan teman-teman kos Nur Farma.}

Terima kasih telah menjadi sahabat sekaligus keluarga keduaku selama menuntut ilmu di kota ini 


\section{KATA PENGANTAR}

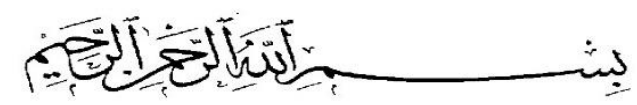

Segala puji bagi Allah SWT yang telah melimpahkan rahmat serta karuniaNya kepada penulis sehingga bisa menyelesaikan penulisan tesis dengan judul "Pengaruh Lingkungan Kerja Dan Motivasi Kerja Terhadap Kepuasan Kerja Guru Dan Dampaknya Pada Kinerja Guru Madrasah Aliyah Di Pulau Bawean”.

Shalawat serta salam semoga tercurah kepada Nabi Agung Muhammad SAW yang telah membimbing umatnya dari gelapnya kekufuran menuju cahaya Islam yang terang benderang.

Selanjutnya, penulis ungkapkan rasa terima kasih dan penghargaan yang tak terhingga kepada orang tua ,adik dan segenap keluarga yang senantiasa mengiringi setiap jengkal langkah kaki penulis dengan untaian doa.

Penulis menyadari keterbatasan pengetahuan yang penulis miliki, karena itu tanpa keterlibatan dan sumbangsih dari berbagai pihak, sulit bagi penulis untuk menyelesaikan Tesis ini. Maka dari itu dengan segenap kerendahan hati penulis ucapkan terima kasih kepada :

1. Prof. Dr. Abdul Haris, M.Ag selaku rektor Universitas Islam Negeri Maulana Malik Ibrahim Malang yang selalu memberikan pengetahuan dan pengalaman yang berharga.

2. Prof. Dr. H Mulyadi, M.Pd.I selaku Direktur Pascasarjana Universitas Islam Negeri Maulana Malik Ibrahim Malang dan para Asisten Direktur atas segala layanan dan fasilitas yang telah diberikan selama penulis menempuh studi 
3. Ketua Program Studi Manajemen Pendidikan Islam, Bapak Dr. H. Wahid Murni, M.Pd.Ak dan Dr. Isti'anah Abubakar, M.Ag selaku sekretaris Program Studi atas motivasi, koreksi dan kemudahan pelayanan selama studi.

4. Dr. H. Munirul Abidin, M.Ag selaku dosen pembimbing I yang telah meluangkan waktu untuk membimbing, mengarahkan, memberi masukan, kemudahan serta memberikan kepercayaan kepada penulis dalam pengerjaan tesis.

5. Dr. H. Abdul Basith, M.Si selaku dosen pembimbing II yang selalu memberikan masukan, bimbingan dan memberi kemudahan dan melancarkan proses penyelesaian tesis ini..

6. Semua staff pengajar atau dosen dan semua staff TU Sekolah Pascasarjana Universitas Islam Negeri Maulana Malik Ibrahim Malang yang telah memberikan bimbingan, mengalirkan ilmu, pengetahuan, pengalaman dan wawasan sebagai pedoman dan kemudahan-kemudahan selama menyelesaikan studi.

7. Bapak kepala sekolah, Seluruh dewan guru dan para pegawai lainnya di Madrasah Aliyah Hasan Jufri, Madrasah Aliyah Mambaul Falah, Madrasah Aliyah Umar Mas’ud, Madrasah Aliyah DarusSalam, Madrasah Aliyah Miftahul Huda yang telah memberikan dukungan, serta partisipasinya selama penulis menyelesaikan tesis sehingga penelitian tesis ini berjalan dengan lancar.

8. rekan dan rekanita senasib seperjuangan di program Studi Manajemen Pendidikan Islam (MPI) angkatan 2016. Sahabat-sahabat Kos Nur Farma 
Sebagai penutup, penulis menyadari dalam tesis ini masih banyak kekurangan dan jauh dari sempurna. Semoga apa yang menjadi kekurangan bisa disempurnakan oleh peneliti selanjutnya. Harapan penulis, semoga karya ini bermanfaat dan menambah khasanah ilmu pengetahuan bagi kita semua, Amin.

Malang, 2018

Penulis 


\section{DAFTAR ISI}

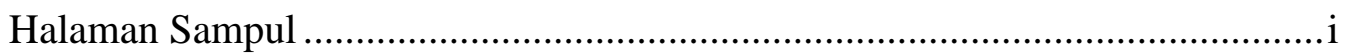

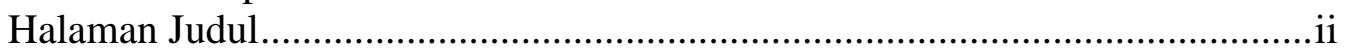

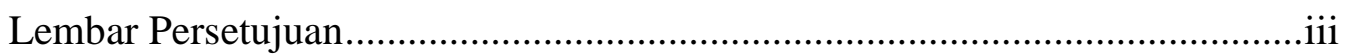

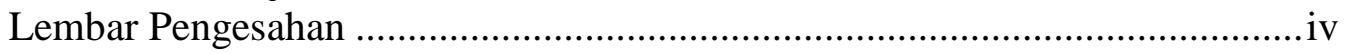

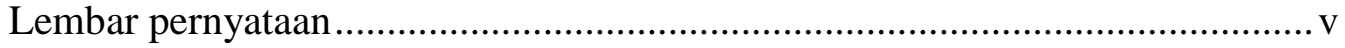

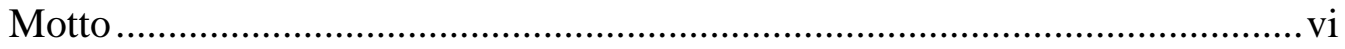

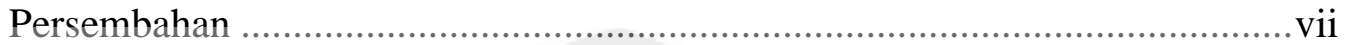

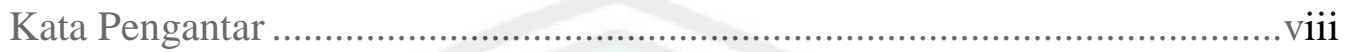

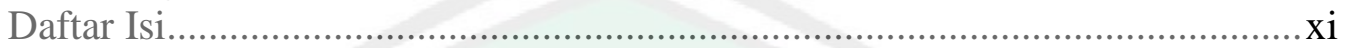

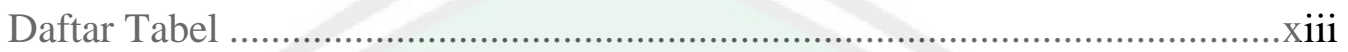

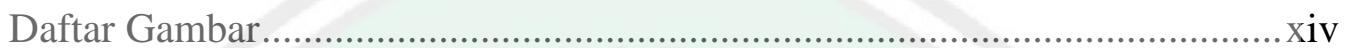

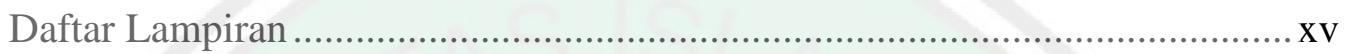

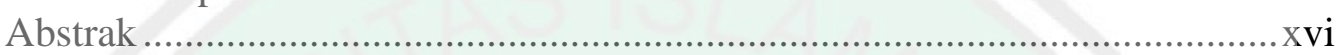

\section{BAB I Pendahuluan}

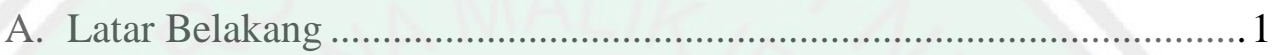

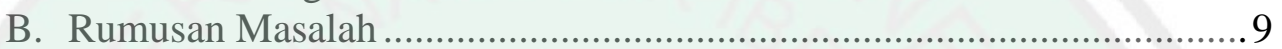

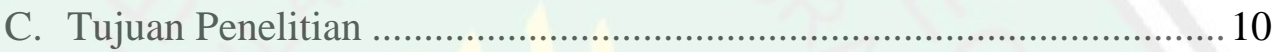

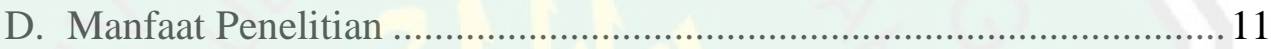

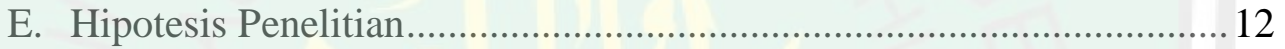

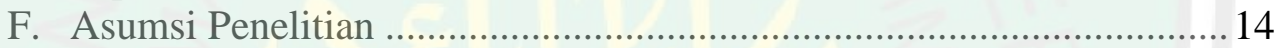

G. Ruang Lingkup penelitian ................................................................ 15

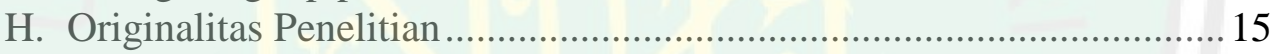

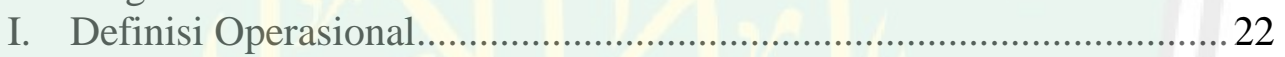

\section{BAB II KAJIAN PUSTAKA}

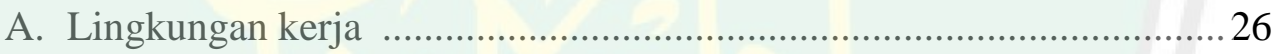

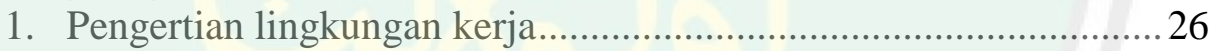

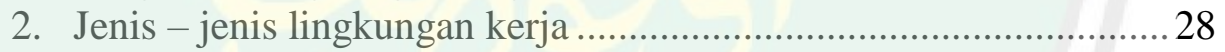

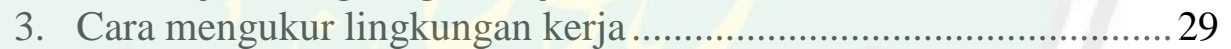

4. Lingkungan kerja dalam perspektif Islam ........................................ 30

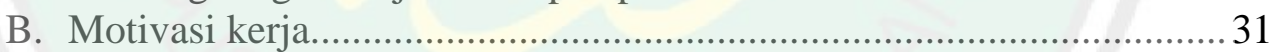

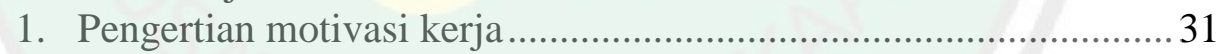

2. Teori kebutuhan Mc clelland .................................................... 32

3. Faktor yang mempengaruhi tinggi rendahnya motivasi kerja..........34

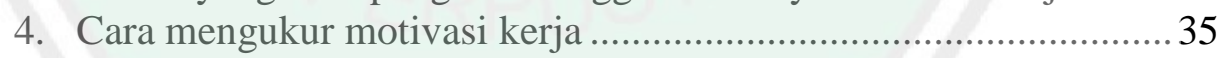

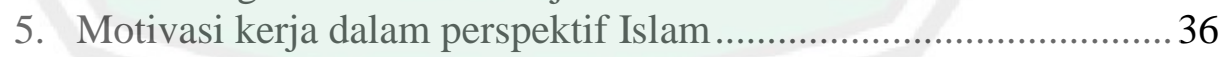

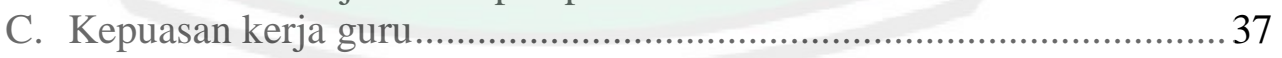

1. Pengertian kepuasan kerja guru .................................................... 37

2. Faktor yang mempengaruhi kepuasan kerja ...................................39

3. Cara mengukur kepuasan kerja .................................................... 41

4. Kepuasan kerja dalam perspektif Islam ........................................42

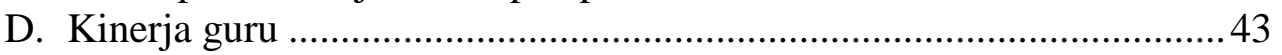

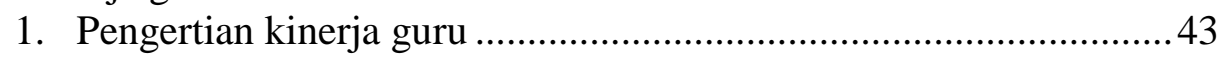

2. Faktor-faktor yang mempengaruhi kinerja guru .............................46

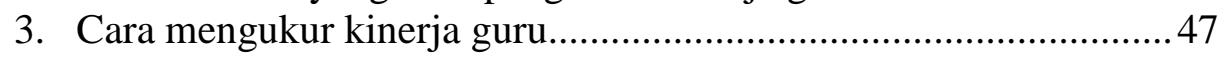

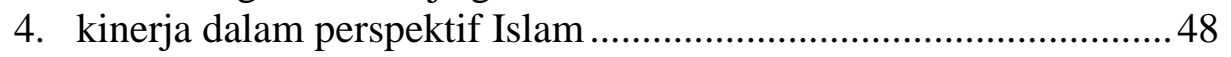

E. Pengaruh antar variabel.......................................................................49 
BAB III METODE PENELITIAN
A. Pendekatan dan Jenis Penelitian .58

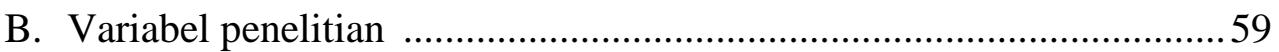

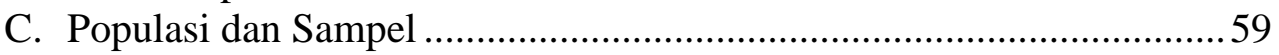

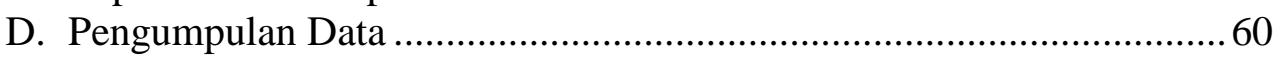

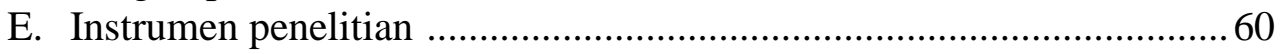

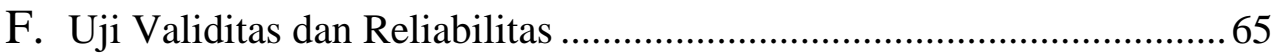

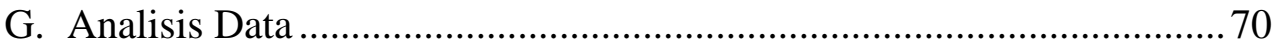
BAB IV HASIL PENELITIAN

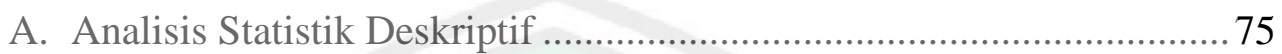

B. Uji Prasyarat Regresi …............................................................ 92

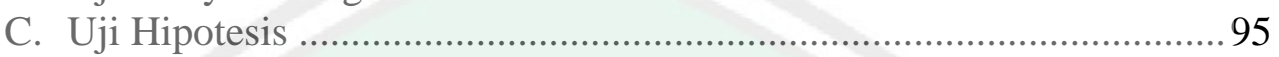

\section{BAB V PEMBAHASAN}

A. Pengaruh Lingkungan Kerja Terhadap Kepuasan Kerja.....................116

B. Pengaruh Motivasi Kerja Terhadap Kepuasan Kerja..........................118

C. Pengaruh Lingkungan Kerja Terhadap Kinerja Guru ........................ 119

D. Pengaruh Motivasi Kerja Terhadap Kinerja Guru ............................. 121

E. Pengaruh Kepuasan Kerja Terhadap Kinerja Guru........................... 122

F. Pengaruh Tidak Langsung Lingkungan Kerja Terhadap Kinerja Guru Melalui Kepuasan Kerja .......................................................... 124

G. Pengaruh Tidak Langsung Motivasi Kerja Terhadap Kinerja Guru Melalui Kepuasan Kerja.

BAB VI PENUTUP
A. Kesimpulan

B. Implikasi Teoritis dan praktik 


\section{DAFTAR TABEL}

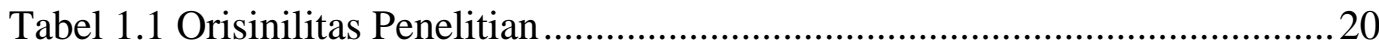

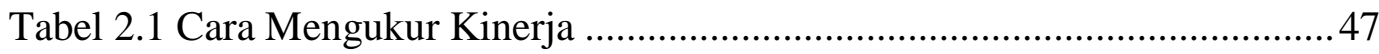

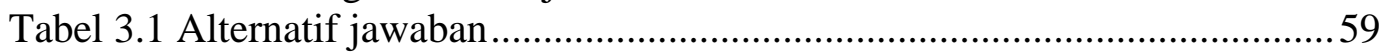

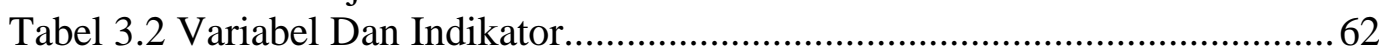

Tabel 3.3 Hasil Uji Coba Validitas Angket Lingkungan Kerja $\left(\mathrm{X}_{1}\right)$.....................66

Tabel 3.4 Hasil Uji Coba Validitas Angket Motivasi Kerja $\left(\mathrm{X}_{2}\right)$.........................66

Tabel 3.5 Hasil Uji Coba Validitas Angket Kepuasan Kerja Guru (Z) .................6 67

Tabel 3.6 Hasil Uji Coba Validitas Angket Kinerja Guru (Y) .............................6 67

Tabel 3.7 Hasil Uji Coba Reliabilitas Instrumen .................................................69

Tabel 4.1 Deskripsi Tanggapan Responden Terhadap Variabel $\mathrm{X}_{1} \ldots \ldots \ldots \ldots \ldots \ldots . . . . . . .75$

Tabel 4.2 Tabulasi Hasil Jawaban Kuesioner Variabel $X_{1}$.................................. 76

Tabel 4.3 Deskripsi Tanggapan Responden Terhadap Variabel $\mathrm{X}_{2}$.....................78

Tabel 4.4 Tabulasi Hasil Jawaban Kuesioner Variabel $X_{2}$................................. 79

Tabel 4.5 Deskripsi Tanggapan Responden Terhadap Variabel Z ......................8 83

Tabel 4.6 Tabulasi Hasil Jawaban Kuesioner Variabel Z ....................................8 84

Tabel 4.7 Deskripsi Tanggapan Responden Terhadap Variabel Y ......................86 86

Tabel 4.8 Tabulasi Hasil Jawaban Kuesioner Variabel Y...................................8 87

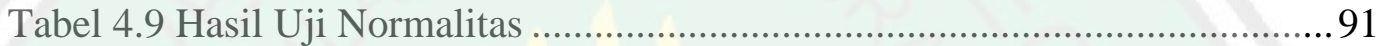

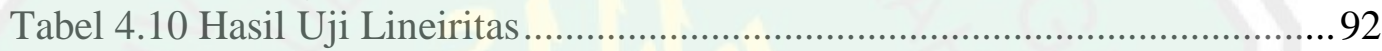

Tabel 4.11 Hasil Uji Multikolineiritas ........................................................... 93

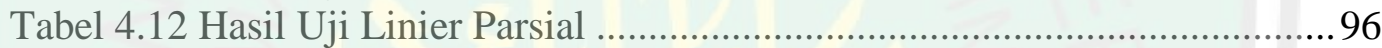

Tabel 4.10 Hasil Uji Linier Secara Simultan ....................................................107 


\section{DAFTAR GAMBAR}

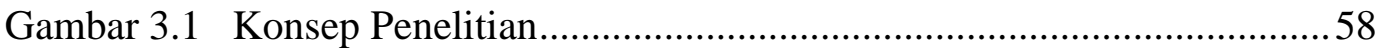

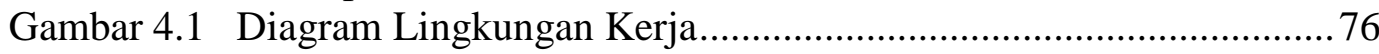

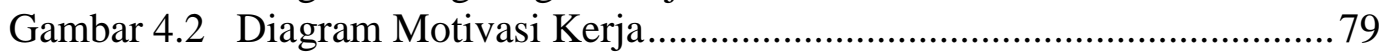

Gambar 4.3 Diagram Kepuasan Kerja Guru ................................................ 84

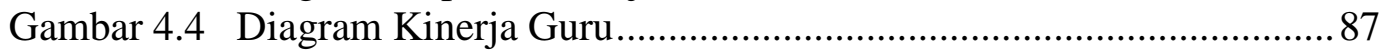

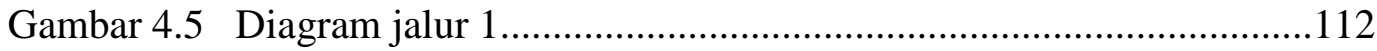

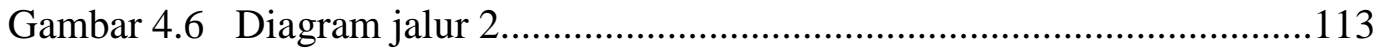




\section{DAFTAR LAMPIRAN}

Lampiran 1 Angket Penelitian

Lampiran 2 Data Uji Coba Angket

Lampiran 3 Uji Normalitas Dan Lineiritas Angket

Lampiran 4 Uji validitas dan reliabilitas Angket

Lampiran 5 Data Penelitian

Lampiran 6 Uji Normalitas Data Penelitian

Lampiran 7 Uji Linieritas Data Penelitian

Lampiran 8 Uji Regresi Data Penelitian

Lampiran 9 Surat Keterangan Telah Melakukan Penelitian 


\begin{abstract}
ABSTRAK
Nasir, Moh. 2018. Pengaruh Lingkungan Kerja Dan Motivasi kerja Terhadap Kepuasan Kerja Guru Dan Dampaknya Pada Kinerja Guru Madrasah aliyah Di Pulau Bawean. Tesis Program Pascasarjana. Program Magister Manajemen Pendidikan Islam, Universitas Islam Negeri Maulana Malik Ibrahim, Malang. Pembimbing: (I) Dr. H. Munirul Abidin, M.Ag. (II) Dr. H. Abdul Basith, M.Si.
\end{abstract}

Kata Kunci: Lingkungan Kerja, Motivasi Kerja, Kepuasan Kerja, Kinerja Guru

Guru merupakan salah satu pilar yang menentukan keberhasilan aktivitas pendidikan di sekolah . Keberadaan guru harus senantiasa diberikan perhatian yang serius, mengingat keberhasilan proses pembelajaran sangat sulit tercapai apabila peran guru tidak maksimal. Sebagai komponen yang mendukung keberhasilan proses pembelajaran, kinerja seorang guru harus senantiasa dipelihara dan ditingkatkan. Namun realita yang ada di lapangan guru kurang memperhatikan kinerjanya, kebanyakan para guru bekerja hanya sekedar melaksanakan tugas dan kewajiban sehari-hari. Kinerja guru dapat dipengaruhi lingkungan kerja, Motiasi kerja dan kepuasan kerja.

Tujuan dari penelitian ini adalah: (1) Menjelaskan pengaruh lingkungan kerja terhadap kepuasan kerja guru Madrasah Aliyah di Pulau Bawean (2) Menjelaskan pengaruh Motivasi kerja terhadap kepuasan kerja guru Madrasah Aliyah di Pulau Bawean (3) Menjelaskan pengaruh lingkungan kerja terhadap kinerja guru Madrasah Aliyah di Pulau Bawean (4) menjelaskan pengaruh motivasi kerja terhadap kinerja guru Madrasah Aliyah di Pulau Bawean (5) Menjelaskan pengaruh kepuasan kerja terhadap kinerja guru Madrasah Aliyah di Pulau Bawean (6) menjelaskan pengaruh tidak langsung antara lingkungan kerja terhadap kinerja guru melalui kepuasan kerja guru (7) Menjelaskan pengaruh tidak langsung antara motivasi kerja terhadap kinerja guru melalui kepuasan kerja guru. Penelitian ini menggunakan pendekatan kuantitatif, dengan jumlah sample sebanyak 100 orang guru, sedangkan analisis data pada penelitian ini dengan menggunakan tekhnik analisis jalur (Path Analisys) dengan bantuan softwere spss.

Hasil penelitian ini menunjukkan bahwa: (1) Ada pengaruh positif dan signifikan antara lingkungan kerja dengan kepuasan kerja guru Madrasah Aliyah di Pulau Bawean, (2) Ada pengaruh positif dan signifikan antara Motivasi kerja dengan kepuasan kerja guru Madrasah Aliyah di Pulau Bawean, (3) Ada pengaruh positif dan signifikan antara lingkungan kerja dengan kinerja guru Madrasah Aliyah di Pulau Bawean, (4) Ada pengaruh positif dan signifikan antara Motivasi kerja dengan kinerja guru Madrasah Aliyah di Pulau Bawean. (5) Ada pengaruh positif dan signifikan antara kepuasan kerja guru dengan kinerja guru Madrasah Aliyah di Pulau Bawean (6) Ada pengaruh tidak langsung antara lingkungan kerja dengan kinerja guru melalui Kepuasan kerja guru Madrasah Aliyah di Pulau Bawean.(7) Ada pengaruh tidak langsung antara lingkungan kerja dengan kinerja guru melalui Kepuasan kerja guru Madrasah Aliyah di Pulau Bawean. 


\begin{abstract}
Nasir, Moh. 2018. Analysis of the Effect of Work Environment and Work Motivation on Teacher Job Satisfaction and Its Impact on Teacher Performance in Islamic Senior High School on Bawean Island. Thesis Graduate program. Master of Management Program in Islamic Education, State Islamic University of Maulana Malik Ibrahim, Malang. Advisors: (I) Dr. H. Munirul Abidin, M.Ag. (II) Dr. H. Abdul Basith, M.Si.
\end{abstract}

Key Words: Work Environment, Work Motivation, Work Satisfaction, Teacher Performance

The teacher is one of the pillars that determine the success of educational activities in schools. The existence of teachers must always be given serious attention, given the success of the learning process is very difficult to achieve if the teacher's role is not optimal. As a component that supports the success of the learning process, the performance of a teacher must always be maintained and improved. But the reality that is in the field of the teacher is not paying attention to its performance, most teachers work only to carry out their daily tasks and obligations. Teacher performance can be influenced by the work environment, work motivation, and job satisfaction.

The purpose of this study are: (1) Explain the influence of the work environment on the job satisfaction of Islamic Senior High School teachers on Bawean Island (2) Explain the effect of work motivation on job satisfaction of Islamic Senior High School teachers on Bawean Island (3) Explain the influence of the work environment on the performance of Islamic Senior High School in Bawean Island (4) explain the effect of work motivation on the performance of Islamic Senior High School teachers in Bawean Island (5) Explain the effect of job satisfaction on the performance of Islamic Senior High School teachers on Bawean Island (6) explain the indirect effect between work environment on teacher performance through teacher job satisfaction (7) Explain the indirect effect of work motivation on teacher performance through teacher job satisfaction. This study uses a quantitative approach, and path analysis techniques using multiple regression analysis techniques.

The results of this study indicate that: (1) There is a positive and significant influence between the work environment and job satisfaction of Islamic Senior High School teachers on Bawean Island, (2) There is a positive and significant influence between work motivation and job satisfaction of Islamic Senior High School teachers on Bawean Island, (3) There is a positive and significant influence between the work environment and the performance of Islamic Senior High School teachers on Bawean Island, (4) There is a positive and significant influence between work motivation and the performance of Madrasah Aliyah teachers on Bawean Island. (5) There is a positive and significant influence between teacher job satisfaction and the performance of Islamic Senior High School teachers on Bawean Island (6) There is an indirect influence between the work environment and teacher performance through job satisfaction of Islamic Senior High School teachers on Bawean Island. (7) There is an indirect influence between the work environment and the teacher's performance through job satisfaction of Islamic Senior High School teachers in Bawean Island. 


\section{مستخلص البحث}

ناصر، محمد 1 | • ب . تحليل تأثير بيئة العمل ودافع العمل على اكتفاء عمل المدرسين وأسباها على

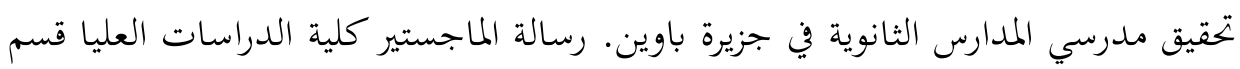

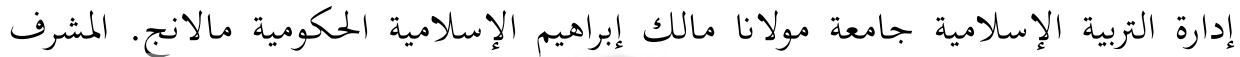

$$
\text { الأول: د. الحاج منير العابدين، المشرف الثاني: د. الجاج عبد البسيط. }
$$

الكلمات الأساسية: بيئة العمل، دافع العمل، اكتفاء العمل و تحقيق العمل.

المدرس هو واحد من الركائز التي تحدد نجاح الأنشطة التعليمية في المدرسة. يجب أن يولي وجود

المعلم اهتماما جديا حيث أن نجاح عملية التعليم صعب في تحقيقها إذا كان دور المدرس لم يكمل. المدرس كعنصر في نجاح عملية التعليم، يجب على تحقيق المدرس أن يحفظ ويزيد في تحقيقها. والواقع أن المدرس لم يهتم تحقيقه. ومعظم المدرسين يعملون بجردا بالواجبات والتزامات اليومية.تحقيق المدرس المؤثر على بيئة العمل ودافعه واكتفاؤه.

ويهدف هذا البحث إلى: ا ـ البيان في تأثير بيئة العمل على اكتفاء عمل المدرسين في المدارس الثانوية بجزيرة وابيان، ب . البيان في تأثير دافع العمل على اكتفاء المدرسين في المدارس الثانوية بجزيرة وابيان، r. البيان في تأثير بيئة العمل على تحقيق المدرسين في المدارس الثانوية بجزيرة وابيان، عـ ـ البيان في تأثير دافع العمل على تحقيق المدرسين في المدارس الثانوية بجزيرة وابيان، ه. البيان في تأثير اكتفاء العمل على تحقيق المدرسين في المدارس الثانوية بجزيرة وابيان، 7 ـ البيان في التأثير غير المباشر بين بيئة العمل على تحقيق المدرسين باكتفاء عمل المدرسين، V. البيان في التأثير غير المباشر بين دافع العمل على تحقيق المدرسين باكتفاء عمل المدرسين. ومدخل هذا البحث هو المدخل الكمي وطريقة تحليل البيانات هي باستخدام أسلوب تحليل الانحدار الخطي المتعدد (Multiple Regression). نتائج هذا البحث تدل على: الـ وجود التأثير الإيجابي بين بيئة العمل واكتفاء عمل المدرسين

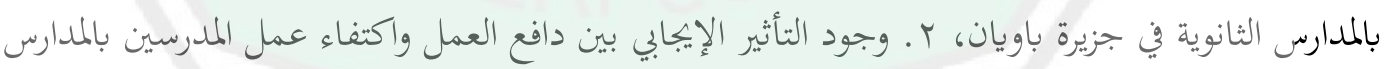
الثانوية في جزيرة باويان، جـ وجوب التأثير الإيجابي بين بيئة العمل وتحقيق المدرسين في المدارس الثانوية بجزيرة وابيان، ــ وجود التأثير الإيجابي بين دافع العمل وتحقيق عمل المدرسين في المدارس الثانوية بجزيرة وابيان، ه. وجود التأثير الإيجابي بين اكتفاء عمل المدرسين وتتقيق المدرسين في المدارس الثانوية بجزيرة وابيان، 7. التأثير غير المباشر بين بيئة العمل وتحقيق المدرسين على اكتفاء عمل المدرسين في المدارس الثانوية بجزيرة

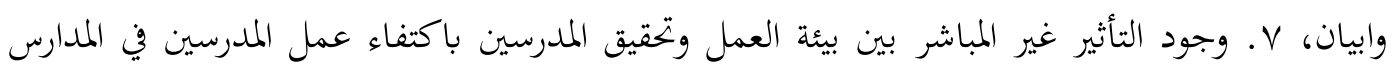




\section{BAB I}

\section{PENDAHULUAN}

\section{A. Latar Belakang}

Keberhasilan suatu organisasi sangat ditentukan oleh kualitas SDM yang berada di dalamnya. Oleh karena itu, peran SDM yang mumpuni sangat diperlukan untuk kemajuan teknologi dan perkembangan informasi, dengan adanya Sumber Daya Manusia (SDM) yang mumpuni, maka akan mempermudah organisasi untuk mencapai tujuannya. Salah satu komponen SDM yang ada di organisasi pendidikan adalah guru.

Guru merupakan salah satu pilar yang menentukan keberhasilan aktivitas pendidikan di sekolah. Keberadaan guru harus senantiasa diberikan perhatian yang serius, mengingat keberhasilan proses pembelajaran sangat sulit tercapai apabila peran guru tidak maksimal. Sebagai komponen yang mendukung keberhasilan proses pembelajaran, kinerja seorang guru harus senantiasa dipelihara dan ditingkatkan. Tujuan pendidikan akan sulit tercapai apabila kinerja guru rendah.

Agar menciptakan guru yang profesional, pemerintah telah membuat aturan persyaratan untuk menjadi guru. Dalam pasal 8 undang-undang No.14 tahun 2005 tentang guru dan dosen menyebutkan bahwa guru wajib memiliki kualifikasi akademik, kompetensi, sertifikat pendidik, sehat jasmani dan rohani, serta memiliki kemampuan untuk mewujudkan tujuan pendidikan nasional.

UU No.14 Tahun 2005 Bab IV pasal 20 (a) tentang guru dan dosen menyatakan bahwa standar prestasi kerja guru dalam melaksanakan tugas 
keprofesionalannya, guru berkewajiban merencanakan pembelajaran, melaksanakan proses pembelajaran yang bermutu serta menilai dan mengevaluasi hasil pembelajaran. Tugas pokok guru tersebut yang diwujudkan dalam kegiatan belajar mengajar merupakan bentuk kinerja guru. ${ }^{2}$

Ukuran kinerja guru terlihat dari rasa tanggung jawabnya dalam menjalankan amanah. Profesi yang diembannya, rasa tanggung jawab moral di pundaknya semua akan tampak pada kepatuhan dan loyalitasnya dalam menjalankan tugasnya sebagai guru di dalam kelas maupun di luar kelas.

Menurut Muhaimin seorang guru yang profesional harus mempunyai karakteristik yakni: (1) komitmen terhadap profesionalitas, yang melekat pada dirinya sikap dedikatif, komitmen terhadap mutu proses dan hasil kerja serta sikap untuk terus berkembang dan maju, (2) menguasai ilmu dan mampu mengembangkan serta menjelaskan fungsinya dalam kehidupan, menjelaskan dimensi teoritis dan praktisnya dalam kehidupan, menjelaskan dimensi teoritis dan praktisnya atau sekaligus melakukan "transfer ilmu pengetahuan, internalisasi serta amaliyah (implementasi)" (3) memiliki kepekaan intelektual dan informasi serta memperbaharui pengetahuan dan keahliannya secara berkelanjutan dan berusaha mencerdaskan peserta didiknya, memberantas kebodohan mereka serta melatih keterampilan sesuai dengan bakat, minat dan kemampuannya. ${ }^{3}$

\footnotetext{
${ }^{2}$ Undang-undang Tentang Guru dan Dosen (Undang-Undang Republik Indonesia No. 14 Tahun 2005 serta UU No.20 Tahun 2003 Tentang SISDIKNAS), (Bandung: Penerbit Citra Umbara, 2006), Hlm.. 26

3 Muhaimin, Wacana Pengembangan Pendidikan Islam, (Yogyakarta: Pustaka Pelajar, 2003), hlm. 217
} 
Untuk menjadikan guru yang profesional maka perlu diadakan pembinaan secara terus menerus dan berkesinambungan, dan menjadikan guru sebagai tenaga kerja yang perlu diperhatikan, dihargai dan diakui keprofesionalannya. Untuk membuat mereka menjadi profesional tidak semata-mata hanya meningkatkan kompetensinya baik melalui pemberian penataran, pelatihan maupun memperoleh kesempatan untuk belajar lagi, namun perlu juga memperhatikan guru dari segi yang lain seperti peningkatan disiplin, pemberian motivasi, pemberian bimbingan melalui supervisi, pemberian insentif, gaji yang layak sehingga memungkinkan guru menjadi puas dalam bekerja sebagai pendidik.

Namun realita yang ada di lapangan guru kurang dalam memperhatikan kinerjanya, kebanyakan para guru bekerja hanya sekedar melaksanakan tugas dan kewajiban sehari-hari. Keadaan ini akan menyebabkan etos kerja para guru menjadi rendah, dengan begitu akan berdampak pada mutu pendidikan dan sumberdaya manusia yang rendah pula. Hal ini sejalan dengan laporan yang dikeluarkan oleh The United Nations Development Programme (UNDP) pada tahun 2011-2012, Indeks Pembangunan Manusia (IPM) atau Human Development Indeks (HDI) peringkat 124 di tahun 2011 dan ke 121 di tahun 2012. Pada tahun yang sama, The United Nationals Educational, Scientific And Curtural Organization (UNESCO) merilis laporan hasil survei Education For All Development Indeks (EDI), yang menempatkan Indonesia berada di peringkat ke 64 dari 120 negara yang disurvei, dengan nilai EDI sebesar 0,938 dari skala 1,000; nilai kemampuan baca dan literasi pada usia 15 tahun ke atas 
sebesar 0,926 dari skala 1,000. Ironisnya dengan skala sebesar itu kualitas pendidikan Indonesia dikategorikan dalam kategori menengah dan setara dengan negara berkembang yang ada di benua Afrika. ${ }^{4}$

Kinerja dan kompetensi guru yang rendah di Indonesia pernah disampaikan oleh menteri pendidikan dan kebudayaan, Muhammad Nuh, yang di buktikan dengan nilai hasil UKG di seluruh Indonesia, dengan nilai rata-rata sebesar 4,25 dari skala 10 .

"Nilai rata-rata uji kompetensi awal guru di 337 kabupaten/kota di bawah rata-rata nasional 42,25. Hannya 154 kabupaten / kota yang nilai rataratanya di atas rata-rata nasional. Nilai tertinggi 97,0 dan terendah 1,0 menunjukkan kesenjangan kualitas guru antar daerah amat lebar. Provinsi dengan nilai rata-rata tertinggi diperoleh Yogyakarta, DKI Jakarta, Bali, Jawa Timur, dan Jawa Tengah. Nilai rata-rata terendah di Maluku, Maluku Utara, Kalimantan Barat, Kalimantan Barat, Kalimantan Tengah, dan Jambi. Untuk tingkat kabupaten/kota, nilai rata-rata uji kompetensi awal (UKA) tertinggi di Blitar, Sukabumi, Gresik, Malang, dan Jembrana. Nilai rata-rata terendah di kabupaten Mentawai, Dogiyai, Barito Utara, Morotai, dan Lampung Barat. Hasil UKA guru itu dipaparkan Menteri Pendidikan dan Kebudayaan Mohammad Nuh, Jumat (16/13), di Jakarta."5

Hasil uji kompetensi tersebut merupakan cerminan dari rendahnya kinerja guru di Indonesia dan tentunya sangat berkaitan dengan IMP dan EDI Indonesia yang rendah berdasarkan riset UNDP dan UNESCO. Kinerja guru yang rendah dapat di pengaruhi oleh banyak hal, salah satu diantaranya adalah kepuasan kerja.

Kepuasan kerja (job satisfaction) guru dan karyawan merupakan faktor yang harus diperhatikan oleh pihak manajemen sebagai upaya memelihara

\footnotetext{
${ }^{4}$ The United Nationals educational, Scientific and curtural organization, education development indeks, (UNESCO, 2013)

${ }^{5}$ Kompas.com Oline. Rata-rata Hasil Uji Kompetensi guru Masih Rendah, (jumat, 12 Maret 2012) di akses pada tanggal 12 desember 2017. Tersedia
} 
tingkat kinerja guru dan karyawan yang diinginkan. Salah satu trend manajemen sumber daya manusia era global ini adalah kemampuan manajer dalam membangun komitmen karyawan dengan mendapatkan lebih banyak orang yang terlibat dan senang dengan pekerjaannya. ${ }^{6}$

Menurut Sinambela dalam Barnawi dan Mohammad arifin, mengemukakan bahwa kepuasan kerja pegawai berhubungan erat dengan kinerja pegawai. Kepuasan kerja guru dapat meningkatkan produktivitas kerja dan disiplin kerja, selain itu, kepuasan kerja dapat menekan tingkat keluarnya guru dan banyaknya respon ketidakpuasan. Guru yang terpuaskan ia akan memiliki semangat kerja dan disiplin kerja yang tinggi, dan tentunya akan berdampak pada tingginya kinerja. Sebaliknya jika kepuasan kerja tidak terpenuhi maka akan banyak melahirkan respon-respon negatif yang berakibat pada terhambatnya upaya pencapaian tujuan organisasi. ${ }^{7}$

Handoko dalam Sutrisno mengemukakan kepuasan kerja adalah keadaan emosional yang menyenangkan atau tidak menyenangkan bagi para karyawan memandang pekerjaan mereka. Kepuasan kerja mencerminkan perasaan seseorang terhadap pekerjaannya. Ini tampak pada sikap positif karyawan terhadap pekerjaan dan segala sesuatu yang dihadapi di lingkungan kerjanya. ${ }^{8}$

Karyawan yang tidak memperoleh kepuasan kerja tidak akan pernah mencapai kepuasan psikologis dan akhirnya akan timbul sikap atau tingkah laku

\footnotetext{
${ }^{6}$ Dessler Gary, Manajemen Sumber Daya Manusia (Jakarta: PT. Prenhallindo, 1997), Hlm. 28. ${ }^{7}$ Barnawi \& Mohammad Arifin, Kinerja guru profesional (Yogyakarta, Ar-Ruzz media:2012)Hlm.133-134.

${ }^{8}$ Sutrisno. Manajemen Sumber Daya Manusia..( Jakarta: Kencana Prenata Media Group: 2008.) Hlm.79
} 
negatif dan pada gilirannya akan menimbulkan frustasi, sebaliknya karyawan yang terpuaskan akan dapat bekerja dengan baik, penuh semangat, aktif dan dapat berprestasi lebih baik dari karyawan yang tidak memperoleh kepuasan kerja $^{9}$

Penelitian yang dilakukan oleh Riduan Zain, dkk, menunjukkan ada korelasi positif antara kepuasan kerja dengan kinerja dosen, sekalipun tingkat hubungan kedua variabel tersebut adalah sedang. ${ }^{10}$ Penelitian yang sama dilakukan oleh Rosita Restiana yang menemukan bahwa kepuasan kerja menjadi faktor penting dalam penentuan kinerja guru di SMP Negeri 1 Rantau selatan. ${ }^{11}$ Dari kedua penelitian di atas menunjukkan bahwa terdapat hubungan antara kepuasan kerja dengan kinerja.

Kepuasan kerja dipengaruhi oleh banyak faktor, hasil penelitian Didik Adi mengatakan bahwa kepuasan kerja pegawai perlu diperhatikan karena pegawai yang merasakan puas dalam bekerja akan mempunyai kinerja yang lebih baik dibandingkan dengan pegawai yang merasakan ketidak puasan di dalam bekerja. Kepuasan kerja dipengaruhi oleh banyak faktor di antaranya adalah kompensasi, lingkungan kerja, kondisi kerja. Sedangkan beberapa penelitian lainnya menemukan bahwa gaji, lingkungan kerja dan fasilitas kerja mempengaruhi kepuasan kerja. ${ }^{12}$ As'ad menyatakan bahwa kepuasan kerja dipengaruhi oleh

\footnotetext{
${ }^{9}$ Ibid Hlm.. 79

${ }^{10}$ Riduan Zain, pengaruh kompensasi dan kepuasan kerja terhadap kinerja dosen di fakultas ilmu tarbiyah dan keguruan uin sunan kalijaga yogyakarta. Manageria: Jurnal Manajemen Pendidikan Islam Volume 2, Nomor 1, Mei 2017/1438

${ }^{11}$ Bestiana, Rsita (2012) hubungan kepuasan kerja, motivasi dan komitmen normatif dengan kinerja guru smpn 1 rantau selatan - labuhan batu. jurnal tabularasa, 9 (2)

${ }^{12}$ Farid Firmansyah. Pengaruh lingkungan kerja, kompensasi dan kepemimpinan, terhadap kepuasan kerja guru dan karyawan di SMA Wachid Hasyim Surabaya, Tadris. 94 Volume 3. Nomor 1. 2008 Hlm.. 95
} 
faktor individu, sosial, fisik dan finansial. Sedangkan Winarno mengemukakan bahwa faktor yang mempengaruhi kepuasan kerja adalah karakteristik individu, karakteristik pekerjaan dan karakteristik organisasi ${ }^{13}$

Kepuasan kerja akan bisa dicapai dengan adanya motivasi kerja yang baik. Motivasi kerja merupakan kondisi yang mendorong seseorang untuk melaksanakan pekerjaannya untuk mencapai tujuan organisasi maupun tujuan individual. Dorongan atau keinginan tiap individu berbeda-beda, hal ini dapat dipengaruhi oleh faktor- faktor dari dalam diri karyawan itu sendiri maupun dari luar. Faktor yang mempengaruhi tinggi rendahnya motivasi kerja seseorang adalah minat/perhatian terhadap pekerjaan, upah/gaji, status sosial dari pekerjaan, pekerjaan yang mengandung pengabdian dan faktor suasana kerja serta hubungan kemanusiaan yang baik. Tinggi rendahnya motivasi kerja sangat berpengaruh terhadap kepuasan kerja yang dapat dicapai karyawan. Motivasi kerja yang tinggi akan mendorong semangat kerja karyawan untuk menyelesaikan tugas-tugasnya.

Penelitian yang dilakukan Edi Siregar, menunjukkan bahwa motivasi kerja berpengaruh positif terhadap kepuasan kerja. ${ }^{14}$ Hasil penelitian Brahmasari menunjukkan bawa terdapat pengaruh positif signifikansi motivasi kerja, kepemimpinan dan budaya organisasi terhadap kepuasan staf pada kinerja

\footnotetext{
${ }^{13}$ As'ad, Moh., Psikologi Industri (Yogyakarta: Liberty, 1999), Hlm.. 195.

${ }^{14}$ Edi Siregar, kinerja individual dan sistem kompensasi finansial terhadap kepuasan kerja, Jurnal Pendidikan Penabur - No.16/Tahun ke-10/Juni 2011. Hlm.. 90
} 
perusahaan. ${ }^{15}$ Dari penelitian di atas bisa diambil kesimpulan bahwa motivasi mempunyai hubungan terhadap kepuasan kerja

Kepuasan kerja juga dipengaruhi oleh lingkungan kerja yaitu tempat di mana para pegawai melaksanakan pekerjaan sehari-hari meliputi keadaan penerangan, pewarnaan, suara, udara, kebersihan, keamanan, serta tata ruang. ${ }^{16}$ Kenyamanan tempat kerja secara fisik dan non fisik (psikis) merupakan harapan bagi tiap karyawan. Upaya mencapai kenyamanan tempat kerja antara lain dapat dilakukan dengan jalan memelihara prasarana fisik seperti kebersihan yang selalu terjaga, penerangan, warna dinding dan perabotan kantor, suara dan tata ruang serta yang berkaitan dengan kondisi psikis. Hal ini memberikan rasa nyaman pada karyawan dalam menyelesaikan pekerjaan sehingga pada akhirnya kondisi kerja akan lebih baik dan membantu mengurangi kejenuhan dan kelelahan.

Pegawai selalu menuntut adanya lingkungan tempat mereka bekerja lebih nyaman sehingga optimalisasi kerja pegawai dapat tercapai dengan baik. Pegawai tidak akan bekerja secara optimal apabila kondisi lingkungan tempat ia bekerja seperti penerangan tidak terpenuhi, suara gaduh, suhu udara terlalu lembap, panas. Selain itu juga perlu diperhatikan tata ruang yaitu penentuan mengenai kebutuhan-kebutuhan ruang, tentang penggunaan secara terperinci dari ruang ini untuk menyiapkan suara susunan yang praktis dari faktor fisik

\footnotetext{
${ }^{15}$ Ida Ayu Brahmasari, pengaruh variabel budaya perusahaan terhadap komitmen karyawan dan kinerja perusahaan kelompok penerbitan Pers jawa pos, disertasi (surabaya: Universitas Airlangga Surabay,2004)

${ }^{16}$ Moekijat.. Tata Laksana Kantor.( Bandung : Alumni. 1995). Hlm.. 155
} 
yang dianggap perlu bagi pelaksanaan kerja perkantoran dengan biaya yang layak. $^{17}$

Dari penelitian yang dilakukan oleh fajar maya sari dapat diketahui bahwa lingkungan kerja berpengaruh signifikan terhadap kepuasan kerja. Lingkungan kerja berpengaruh terhadap kepuasan kerja karena pada dasanya lingkungan kerja merupakan faktor eksternal yang dibutuhkan untuk mencapai kondisi yang nyaman dalam bekerja. ${ }^{18}$

Berdasarkan beberapa uraian yang telah dijelaskan di atas, maka peneliti berkeinginan untuk meneliti lebih jauh konsep-konsep kinerja guru di Madrasah Aliyah, yang berkaitan dengan lingkungan kerja, motivasi kerja, kompensasi serta kepuasan kerja guru dan dampaknya terhadap kinerja guru yang ada Madrasah Aliyah di Pulau Bawean . Oleh karena itu, penelitian ini mengambil judul "Pengaruh Lingkungan Kerja, Dan Motivasi Kerja, Terhadap Kepuasan Kerja Guru dan Dampaknya Pada Kinerja Guru Madrasah Aliyah di Pulau Bawean"

\section{B. Rumusan Masalah}

Berdasarkan penjelasan latar belakang, maka dapat dirumuskan permasalahan yang diperoleh sebagai berikut:

\footnotetext{
${ }^{17}$ The Liang Gie. Efisiensi Kerja Bagi Pembangunan Negara.( Jakarta :Erlangga. 1992). Hlm.. 186 ${ }^{18}$ Fajar Maya Sari, Pengaruh Kompetensi Dan Lingkungan Kerja Terhadap Kepuasan Kerja Dan Kinerja Guru Di SD Negeri Kecamatan Gondang Mojokerto. DIE, Jurnal Ilmu Ekonomi \& Manajemen April 2013, Vol. 9 No.2. Hlm. 150
} 
1. Apakah ada pengaruh yang signifikan antara lingkungan kerja terhadap kepuasan kerja guru Madrasah Aliyah di Pulau Bawean?

2. Apakah ada pengaruh yang signifikan antara motivasi kerja terhadap kepuasan kerja guru Madrasah Aliyah di Pulau Bawean?

3. Apakah ada pengaruh yang signifikan antara lingkungan kerja terhadap kinerja guru Madrasah Aliyah di Pulau Bawean?

4. Apakah ada pengaruh yang signifikan antara motivasi kerja terhadap kinerja guru Madrasah Aliyah di Pulau Bawean?

5. Apakah ada pengaruh yang signifikan antara kepuasan kerja terhadap kinerja guru Madrasah Aliyah di Pulau Bawean?

6. Apakah ada pengaruh tidak langsung antara lingkungan kerja terhadap kinerja guru melalui kepuasan kerja guru ?

7. Apakah ada pengaruh tidak langsung antara motivasi kerja terhadap kinerja guru melalui kepuasan kerja guru ?

\section{Tujuan Penelitian}

Berdasarkan rumusan masalah penelitian sebagaimana diuraikan di atas, maka tujuan penelitian ini, adalah:

1. Untuk menjelaskan pengaruh lingkungan kerja terhadap kepuasan kerja guru Madrasah Aliyah di Pulau Bawean

2. Untuk menjelaskan pengaruh Motivasi kerja terhadap kepuasan kerja guru Madrasah Aliyah di Pulau Bawean

3. Untuk menjelaskan pengaruh lingkungan kerja terhadap kinerja guru Madrasah Aliyah di Pulau Bawean 
4. Untuk menjelaskan pengaruh motivasi kerja terhadap kinerja guru Madrasah Aliyah di Pulau Bawean

5. Untuk menjelaskan pengaruh kepuasan kerja terhadap kinerja guru Madrasah Aliyah di Pulau Bawean

6. Untuk menjelaskan pengaruh tidak langsung antara lingkungan kerja terhadap kinerja guru melalui kepuasan kerja guru

7. Untuk menjelaskan pengaruh tidak langsung antara motivasi kerja terhadap kinerja guru melalui kepuasan kerja guru

\section{Manfaat Penelitian}

Hasil penelitian ini diharapkan dapat digunakan dan bermanfaat baik secara teoritis dan praktis bagi berbagai pihak antara lain:

1. Manfaat Teoritis

Secara teoritis hasil penelitian ini diharapkan bermanfaat bagi pengembangan

ilmu pengetahuan terutama dalam implementasi teoritis peningkatan kepuasan kerja dan kinerja guru.

2. Manfaat praktis

a. Bagi sekolah

Penelitian ini diharapkan bisa digunakan sebagai bahan informasi bagi lembaga pendidikan sekolah, mengenai faktor-faktor yang dapat meningkatkan kepuasan kerja dan kinerja guru.

b. Bagi Guru

Penelitian ini diharapkan dapat digunakan sebagai bahan masukan dan informasi bagi guru agar selalu berupaya komitmen dalam melaksanakan 
tugas dan kewajibannya sebagai pendidik dan pengajar, serta menambah wawasan dan pengetahuan guru tentang bagaimana mengoptimalkan kinerja dalam upaya meningkatkan kualitas pembelajaran di sekolah.

c. Bagi peneliti selanjutnya

Hasil penelitian ini di harapkan dapat menambah perbendaharaan dan memperkaya informasi empiris dalam hal lingkungan kerja, motivasi kerja, kompensasi dan kepuasan kerja sehingga bermanfaat bagi peningkatan kinerja guru yang dapat dipakai sebagai data banding atau rujukan dengan mengubah atau menambah variabel lain sekaligus dapat menyempurnakan penelitian ini.

\section{E. Hipotesis Penelitian}

Hipotesis penelitian ini berdasarkan kajian teori yang mengupas tentang lingkungan kerja motivasi kerja, kompensasi, kepuasan kerja dan kinerja guru. Sehingga hipotesis dalam penelitian ini merupakan rangkuman dari kesimpulan teori-teori tersebut.

Hipotesis merupakan dugaan sementara terkait dengan hasil dari penelitian yang akan dilaksanakan. Secara umum hipotesis di bagi menjadi dua bagian yaitu hipotesis alternatif dan hipotesis nol. Suatu hipotesis sangat diperlukan mengingat keberadaannya yang akan dapat mengarahkan penelitian. Dalam hal ini, peneliti akan berupaya melakukan pembuktian terhadap suatu hipotesis 
untuk di uji kebenarannya. ${ }^{19}$ Berdasarkan pembagian hipotesis tersebut maka hipotesis alternatif dalam penelitian ini dapat di rumuskan sebagai berikut:

1. Ada pengaruh signifikan lingkungan kerja terhadap kepuasan kerja guru Madrasah Aliyah di Pulau Bawean

2. Ada pengaruh signifikan motivasi kerja terhadap kepuasan kerja guru Madrasah Aliyah di Pulau Bawean

3. Ada pengaruh signifikan lingkungan kerja terhadap kinerja guru Madrasah Aliyah di Pulau Bawean

4. Ada pengaruh signifikan motivasi kerja terhadap kinerja guru Madrasah Aliyah di Pulau Bawean

5. Ada pengaruh signifikan kepuasan kerja terhadap kinerja guru Madrasah Aliyah di Pulau Bawean

6. Ada pengaruh tidak langsung lingkungan kerja dengan kinerja guru melalui kepuasan kerja guru

7. Ada pengaruh tidak langsung motivasi kerja dengan kinerja guru melalui kepuasan kerja guru

Sedangkan hipotesis nol dalam penelitian ini dapat dirumuskan sebagai berikut:

1. Tidak ada pengaruh signifikan lingkungan kerja terhadap kepuasan kerja guru Madrasah Aliyah di Pulau Bawean

${ }^{19}$ Muhammad Nisfiannoor, Pendekatan Statistika Modern Untuk Ilmu Sosial (Jakarta: Salemba Humanika, 2009), Hlm.. 8. 
2. Tidak ada pengaruh signifikan motivasi kerja terhadap kepuasan kerja guru Madrasah Aliyah di Pulau Bawean

3. Tidak ada pengaruh signifikan lingkungan kerja terhadap kinerja guru Madrasah Aliyah di Pulau Bawean

4. Tidak ada pengaruh signifikan motivasi kerja terhadap kinerja guru Madrasah Aliyah di Pulau Bawean

5. Tidak ada pengaruh signifikan kepuasan kerja terhadap kinerja guru Madrasah Aliyah di Pulau Bawean

6. Tidak ada pengaruh tidak langsung lingkungan kerja dengan kinerja guru melalui kepuasan kerja guru

7. Tidak ada pengaruh tidak langsung motivasi kerja dengan kinerja guru melalui kepuasan kerja guru

\section{F. Asumsi Penelitian}

Asumsi penelitian merupakan anggapan dasar yang dijadikan sebagai kerangka berpikir pada penelitian yang sedang dilakukan. Asumsi yang pada umumnya dipegang atau dipercaya tentang hubungan sebab akibat harus juga diperhitungkan. Untuk mengetahui asumsi penelitian yang dilakukan ini, dapat dijabarkan dengan beberapa kerangka yang akan dikemukakan diantaranya:

1. Faktor - faktor yang mempengaruhi kinerja guru diluar variabel penelitian dianggap konstan

2. Gambaran tentang lingkungan kerja, motivasi kerja, kepuasan kerja dan kinerja guru pada obyek penelitian merupakan kondisi yang dapat diamati, dialami dan dirasakan guru pada lokasi penelitian. Dengan demikian 
responden mampu memberikan jawaban yang obyektif terhadap situasi dan kondisi yang ada di tempat kerjanya sehingga hasil penelitian ini bisa menggambarkan keadaan yang sebenarnya.

3. Pada saat pengisian angket atau kuesioner para responden dalam keadaan tidak ada perasaan tertekan sehingga obyektif dalam pengisian angket.

\section{G. Ruang Lingkup Penelitian}

Agar penelitian ini dapat dilakukan secara maksimal dan terfokus, maka ruang lingkup penelitian ini dibatasi pada: (1) lokasi penelitian, (2) variabel penelitian.

1. Penelitian ini dilaksanakan di 5 Madrasah Aliyah yang ada di Bawean, yaitu: MA Hasan Jufri, MA Umar Mas’ud, MA Mambaul Falah, MA Darussalam , dan MA Miftahul Huda

2. Penelitian ini menggunakan dua variabel bebas, satu variabel intervening dan satu variabel terikat. variabel bebas terdiri dari: lingkungan kerja dengan sub variabel lingkungan kerja fisik dan lingkungan kerja non fisik dan motivasi kerja dengan sub variabel kebutuhan akan prestasi, kebutuhan akan kekuasaan dan kebutuhan akan afiliasi. Sedangkan variabel intervening dalam penelitian ini adalah kepuasan kerja dengan sub variabel upah, pekerjaan, kesempatan promosi dan rekan kerja. Untuk variabel bebasnya dalam penelitian ini yaitu: kinerja guru dengan sub variabel perencanaan pembelajaran, pelaksanaan pembelajaran dan penilaian pembelajaran.

\section{H. Originalitas Penelitian}


Pada bagian ini, peneliti menyajikan perbedaan dan persamaan bidang kajian yang diteliti antara peneliti dengan peneliti-peneliti sebelumnya. Hal ini perlu peneliti kemukakan untuk menghindari adanya pengulangan kajian terhadap hal-hal sama. Dengan demikian akan diketahui sisi-sisi apa yang membedakan antara penelitian yang akan dilakukan dengan penelitian terdahulu. Penelitian-penelitian ini adalah:

Dalam penelitiannya Anita Anggreini Batubara yang berjudul pengaruh lingkungan kerja, kompensasi dan komitmen terhadap kinerja guru MAN di Medan. Penelitian ini bertujuan untuk menganalisis pengaruh Penelitian ini bertujuan untuk (1) menjelaskan tingkat lingkungan kerja, kompensasi, komitmen, dan kinerja guru, (2) menjelaskan pengaruh lingkungan kerja terhadap kinerja guru, (3) menjelaskan pengaruh kompensasi terhadap kinerja (4) menjelaskan komitmen terhadap kinerja guru, dan (5) menjelaskan pengaruh secara bersama-sama lingkungan kerja, kompensasi, dan komitmen terhadap kinerja guru MAN di Kota Medan. Penelitian ini dirancang dengan menggunakan pendekatan kuantitatif, rancangan berjenis korelasi. Pengumpulan data menggunakan empat jenis angket tentang lingkungan kerja, kompensasi, komitmen, dan kinerja guru. Jumlah responden dalam penelitian ini adalah 89 orang. Data dianalisis dengan menggunakan statistik deskriptif dan teknik analisis regresi linear berganda.

Dari hasil pengolahan data diketahui bahwa (1) lingkungan kerja dan kompensasi tergolong kategori tinggi, sedangkan gambaran komitmen dan kinerja guru tergolong sangat tinggi. (2) ada pengaruh positif dan signifikan 
lingkungan kerja terhadap kinerja guru. (3) ada pengaruh positif dan signifikansi kompensasi terhadap kinerja guru, (4) ada pengaruh positif dan signifikansi komitmen terhadap kinerja guru, (5) ada pengaruh positif dan signifikan secara simultan lingkungan kerja, kompensasi, dan komitmen terhadap kinerja guru MAN di Kota Medan. ${ }^{20}$

Penelitian lain berkaitan dengan kinerja guru dilakukan juga dalam penelitian Fayruzah El-Faradis yang berjudul Pengaruh Kompetensi Manajerial Kepala Sekolah dan Motivasi Kerja terhadap Kinerja Guru di Tarbiyatul Muallimin Al-Islamiyah (TMI) Putri Al-Amien Prenduan Sumenep Madura. Penelitian ini bertujuan untuk menjelaskan: (1) menjelaskan pengaruh kompetensi manajerial kepala sekolah terhadap kinerja guru pada TMI Putri AlAmien Prenduan, (2) menjelaskan pengaruh motivasi kerja guru terhadap kinerja guru pada TMI Putri Al-Amien Prenduan, (3) menjelaskan pengaruh kompetensi manajerial kepala sekolah dan motivasi kerja guru terhadap kinerja guru pada TMI Putri Al-Amien Prenduan.

Rancangan yang digunakan dalam penelitian ini adalah dengan menggunakan pendekatan kuantitatif. Pengumpulan data dalam penelitian ini menggunakan angket yang terdiri dari variabel kompetensi manajerial kepala sekolah, motivasi kerja, dan kinerja guru. Jumlah responden dalam penelitian ini adalah 85 orang. Sementara untuk uji hipotesis digunakan teknik analisis jalur

${ }^{20}$ Anita Anggreini Batubara ,pengaruh lingkungan kerja, kompensasi dan komitmen terhadap kinerja guru MAN di medan (Malang: PPS Universitas Islam Negeri Malang 2016): Tesis tidak diterbitkan 
(path analysis) dengan menggunakan teknik analisis regresi linier berganda (multiple regression).

Hasil analisis data membuktikan bahwa (1) ada pengaruh kompetensi manajerial terhadap kinerja guru, 2) ada pengaruh motivasi kerja terhadap kinerja guru, (3) ada pengaruh kompetensi manajerial kepala sekolah dan motivasi kerja terhadap kinerja guru. ${ }^{21}$

Penelitian lain berkaitan dengan kinerja guru dilakukan juga dalam penelitian Fajar Maya Sari yang berjudul Pengaruh Kompetensi Dan Lingkungan Kerja Terhadap Kepuasan Kerja Dan Kinerja Guru Di SD Negeri Kecamatan Gondang Mojokerto. Tujuan dalam penelitian ini adalah untuk mengetahui pengaruh kompetensi dan lingkungan kerja terhadap kepuasan kerja dan kinerja guru di SD Negeri di Kecamatan Gondang Mojokerto.

Populasi dalam penelitian ini adalah seluruh guru Sekolah Dasar Negeri (SDN) di 23 SDN yang ada di Kecamatan Gondang, yang berjumlah 182 orang. Alat untuk instrumen pengumpulan data yang digunakan adalah daftar pertanyaan atau kuisioner. penelitian ini menggunakan teknik analisis SEM (Structural Equation Modelling). Metode Persamaan Struktural (Structural Equation Modelling = SEM). Hasil penelitian (1)Kompetensi dan lingkungan kerja berpengaruh signifikan dan positif terhadap kepuasan kerja guru SD Negeri di Kecamatan Gondang, namun lingkungan kerja mempunyai pengaruh yang lebih besar dari pada kompetensi. (2)Kompetensi mempunyai pengaruh yang

${ }^{21}$ Fayruzah El-Faradis, Pengaruh Kompetensi Manajerial Kepala Sekolah dan Motivasi Kerja terhadap Kinerja Guru di Tarbiyatul Muallimin Al-Islamiyah (TMI) Putri Al-Amien Prenduan Sumenep Madura. (Malang: PPS Universitas Islam Negeri Malang 2016): Tesis tidak diterbitkan 
tidak signifikan dan positif terhadap kinerja guru SD Neger di Kecamatan Gondang.(3)Lingkungan kerja mempunyai pengaruh yang tidak signifikan dan negatif terhadap kinerja guru SD Negeri di Kecamatan Gondang. (4) Kepuasan kerja mempunyai pengaruh yang signifikan dan positif terhadap kinerja guru SD Negeri di Kecamatan Gondang. ${ }^{22}$

Penelitian tentang kepuasan kerja dan kinerja guru juga dilakukan oleh M. Kharis Fadillah, membuktikan ada pengaruh antara motivasi kerja guru dengan kepuasan kerja, yang pada akhirnya dapat meningkatkan kualitas kinerja guru. ${ }^{23}$

Dengan adanya dorongan dalam diri guru untuk berprestasi membuat guru dapat menggerak kan siswa untuk belajar dan kepuasan kerja akan memberikan rasa kesesuaian akan pekerjaan dengan kepribadian guru yang membuat guru akan senang dalam bekerja dan tentunya hal tersebut akan berdampak pada meningkatnya kinerja guru.

Penelitian yang dilakukan oleh I Gusti Ayu Dewi Adnyani tentang Pengaruh Kompensasi Dan Motivasi Terhadap Kinerja Karyawan Dengan Kepuasan Kerja Sebagai Variabel Intervening, menemukan bahwa kompensasi berpengaruh positif terhadap kepuasan kerja, motivasi berpengaruh positif dan signifikan terhadap kepuasan kerja, kompensasi berpengaruh positif dan signifikan terhadap kinerja karyawan, motivasi berpengaruh positif dan signifikan terhadap kinerja karyawan, kepuasan kerja berpengaruh positif dan

${ }^{22}$ Fajar Maya Sari.Pengaruh Kompetensi Dan Lingkungan Kerja Terhadap Kepuasan Kerja Dan Kinerja Guru Di Sd Negeri Kecamatan Gondang Mojokerto. DIE, Jurnal Ilmu Ekonomi \& Manajemen April 2013, Vol. 9 No.2

${ }^{23}$ M. Kharis Fadillah, Pengaruh Keefektifan kepemimpinan, Budaya Organisasi, Motivasi Kerja, Komitmen Organisasi Dan Kepuasan Kerja Terhadap Kinerja Guru Madrasah Aliyah Negeri Di Malang Raya. (Malang: PPS Universitas Islam Negeri Malang 2016): Disertasi tidak diterbitkan 
signifikan terhadap kinerja karyawan dan kepuasan kerja memediasi pengaruh kompensasi dan motivasi terhadap kinerja karyawan. ${ }^{24}$

Dari penelitian I Gusti Ayu Dewi Adnyani dapat diambil kesimpulan bahwa semakin baik kompensasi dan motivasi yang diterima oleh karyawan maka kepuasan kerja akan meningkat, dan tentunya akan berdampak pada meningkatnya kinerja karyawan

Tabel 1.1 perbedaan dan persamaan antara peneliti dengan peneliti sebelumnya

\begin{tabular}{|c|c|c|c|c|}
\hline No & $\begin{array}{l}\text { Nama peneliti, judul } \\
\text { dan tahun penelitian }\end{array}$ & Persamaan & Perbedaan & Originalitas \\
\hline 1 & $\begin{array}{l}\text { Anita Anggreini } \\
\text { Batubara, Tesis (2016) } \\
\text { pengaruh lingkungan } \\
\text { kerja, kompensasi dan } \\
\text { komitmen terhadap } \\
\text { kinerja guru MAN di } \\
\text { medan. }\end{array}$ & $\begin{array}{l}\text {-Meneliti } \\
\text { Lingkunga } \\
\text { n kerja, } \\
\text { kompensasi } \\
\text { sebagai } \\
\text { variabel } \\
\text { bebas } \\
\text {-Kinerja } \\
\text { guru } \\
\text { sebagai } \\
\text { variabel } \\
\text { terikat }\end{array}$ & $\begin{array}{l}\text {-pengaruh } \\
\text { komitmen } \\
\text { sebagai } \\
\text { variabel bebas }\end{array}$ & $\begin{array}{l}\text { - } \\
\text { menggunaka } \\
\mathrm{n} \text { kepuasan } \\
\text { kerja sebagai } \\
\text { penghubung } \\
\text {-Analisis } \\
\text { data } \\
\text { menggunaka } \\
\mathrm{n} \quad \text { metode } \\
\text { SEM } \\
\text { (Structural } \\
\text { Equation } \\
\text { Modelling) } \\
\text {-Lokasi } \\
\text { penelitian } \\
\text { Madrasah } \\
\text { Aliyah di } \\
\text { Pulau } \\
\text { Bawean }\end{array}$ \\
\hline 2 & $\begin{array}{l}\text { Fayruzah El-Faradis } \\
\text { Tesis (2016) Pengaruh } \\
\text { Kompetensi Manajerial } \\
\text { Kepala Sekolah dan } \\
\text { Motivasi Kerja } \\
\text { Terhadap Kinerja Guru }\end{array}$ & $\begin{array}{l}\text {-Meneliti } \\
\text { motivasi } \\
\text { kerja } \\
\text { sebagai } \\
\text { variabel } \\
\text { bebas }\end{array}$ & $\begin{array}{l}\text {-Pengaruh } \\
\text { Kompetensi } \\
\text { Manajerial } \\
\text { Kepala } \\
\text { Sekolah }\end{array}$ & $\begin{array}{l}\text { - } \\
\text { menggunaka } \\
\text { n kepuasan } \\
\text { kerja sebagai } \\
\text { penghubung }\end{array}$ \\
\hline
\end{tabular}

${ }^{24}$ I Gusti Ayu Dewi Adnyani, Pengaruh Kompensasi Dan Motivasi Terhadap Kinerja Karyawan Dengan Kepuasan Kerja Sebagai Variabel Intervening. E Jurnal Manajemen Unud, 5, 2016. ISSN 2302-8912 


\begin{tabular}{|c|c|c|c|c|}
\hline & $\begin{array}{lr}\text { di Tarbiyatul Muallimin } \\
\text { Al-Islamiyah } & \text { (TMI) } \\
\text { Putri } & \text { Al-Amien } \\
\text { Prenduan } & \text { Sumenep } \\
\text { Madura } & \end{array}$ & $\begin{array}{l}\text {-Kinerja } \\
\text { guru } \\
\text { sebagai } \\
\text { variabel } \\
\text { terikat }\end{array}$ & & $\begin{array}{l}\text { - tiga variabel } \\
\text { independen } \\
\text { yaitu } \\
\text { lingkungan } \\
\text { kerja, } \\
\text { motivasi } \\
\text { kerja, dan } \\
\text { kompensasi } \\
\text { guru. } \\
\text { Penggunaan } \\
\text { satu } \\
\text { variabel } \\
\text { dependen } \\
\text { yaitu kinerja } \\
\text { guru } \\
\text { - Lokasi } \\
\text { penelitian } \\
\text { Madrasah } \\
\text { Aliyah di } \\
\text { Pulau } \\
\text { Bawean }\end{array}$ \\
\hline 3 & $\begin{array}{lr}\text { Fajar Maya Sari, Jurnal } \\
\text { (2013) Kompetensi Dan } \\
\text { Lingkungan } & \text { Kerja } \\
\text { Terhadap } & \text { Kepuasan } \\
\text { Kerja Dan Kinerja Guru } \\
\text { Di SD } r \text { Negeri } \\
\text { Kecamatan } & \text { Gondang } \\
\text { Mojokerto. }\end{array}$ & $\begin{array}{l}\text {-Meneliti } \\
\text { Lingkunga } \\
\mathrm{n} \quad \text { kerja, } \\
\text { sebagai } \\
\text { variabel } \\
\text { bebas } \\
\text {-Kinerja } \\
\text { guru } \\
\text { sebagai } \\
\text { variabel } \\
\text { terikat } \\
\text {-kepuasan } \\
\text { kerja } \\
\text { sebagai } \\
\text { variabel } \\
\text { penghubun } \\
\text { g }\end{array}$ & $\begin{array}{l}\text {-kompetensi } \\
\text { sebagai } \\
\text { variabel bebas }\end{array}$ & $\begin{array}{l}\text { - tiga variabel } \\
\text { independen } \\
\text { yaitu } \\
\text { lingkungan } \\
\text { kerja, } \\
\text { motivasi } \\
\text { kerja, dan } \\
\text { kompensasi } \\
\text { guru. } \\
\text { Penggunaan } \\
\text { satu } \\
\text { variabel } \\
\text { dependen } \\
\text { yaitu kinerja } \\
\text { guru } \\
\quad \text { - Lokasi } \\
\text { penelitian } \\
\text { Madrasah } \\
\text { Aliyah di } \\
\quad \text { Pulau } \\
\quad \text { Bawean } \\
\end{array}$ \\
\hline 4. & $\begin{array}{lr}\text { M. Kharis } & \text { Fadlillah, } \\
\text { Disertasi, } & (2016) \\
\text { Pengaruh } & \text { Keefektifan } \\
\text { kepemimpinan, Budaya }\end{array}$ & $\begin{array}{l}\text { Meneliti } \\
\text { Motivasi } \\
\text { kerja, } \\
\text { sebagai }\end{array}$ & $\begin{array}{l}\text { Keefektifan } \\
\text { kepemimpinan } \\
\text { Organisasi }\end{array}$ & $\begin{array}{l}\text { - tiga variabel } \\
\text { independen } \\
\text { yaitu } \\
\text { lingkungan }\end{array}$ \\
\hline
\end{tabular}




\begin{tabular}{|c|c|c|c|c|}
\hline & $\begin{array}{lr}\text { Organisasi, } & \text { Motivasi } \\
\text { Kerja, } & \text { Komitmen } \\
\text { Organisasi } & \text { Dan } \\
\text { Kepuasan } & \text { Kerja } \\
\text { Terhadap Kinerja Guru } \\
\text { Madrasah } & \text { Aliyah } \\
\text { Negeri Di Malang Raya }\end{array}$ & $\begin{array}{l}\text { variabel } \\
\text { bebas } \\
\text {-Kinerja } \\
\text { guru } \\
\text { sebagai } \\
\text { variabel } \\
\text { terikat } \\
\text {-kepuasan } \\
\text { kerja } \\
\text { sebagai } \\
\text { variabel } \\
\text { penghubun } \\
\text { g }\end{array}$ & $\begin{array}{l}\text { sebagai } \\
\text { variabel bebas }\end{array}$ & $\begin{array}{l}\text { kerja, } \\
\text { motivasi } \\
\text { kerja, dan } \\
\text { kompensasi } \\
\text { guru. } \\
\text { - Lokasi } \\
\text { penelitian } \\
\text { Madrasah } \\
\text { Aliyah di } \\
\text { Pulau } \\
\text { Bawean }\end{array}$ \\
\hline 5 & $\begin{array}{lr}\text { I Gusti Ayu Dewi } \\
\text { Adnyani, } \\
\text { Kinerja (2016) Pengaru } \\
\text { h Kompensasi Dan } \\
\text { Motivasi } r \text { Terhadap } \\
\text { Kinerja } & \text { Karyawan } \\
\text { Dengan Kepuasan Kerja } \\
\text { Sebagai r } \\
\text { Intervening. }\end{array}$ & $\begin{array}{l}\text {-Meneliti } \\
\text { Motivasi } \\
\text { kerja, dan } \\
\text { kompensasi } \\
\text { sebagai } \\
\text { variabel } \\
\text { bebas } \\
\text {-Kinerja } \\
\text { guru } \\
\text { sebagai } \\
\text { variabel } \\
\text { terikat } \\
\text {-kepuasan } \\
\text { kerja } \\
\text { sebagai } \\
\text { variabel } \\
\text { penghubun } \\
\text { g }\end{array}$ & $\begin{array}{l}\text {-Memakai dua } \\
\text { variabel bebas } \\
\text {-Sample } \\
\text { karyawan pada } \\
\text { PT. Sinar } \\
\text { Sosro Pabrik } \\
\text { Bali }\end{array}$ & $\begin{array}{l}\text { - tiga variabel } \\
\text { independen } \\
\text { yaitu } \\
\text { lingkungan } \\
\text { kerja, } \\
\text { motivasi } \\
\text { kerja, dan } \\
\text { kompensasi } \\
\text { guru. } \\
\text { - Lokasi } \\
\text { penelitian } \\
\text { Madrasah } \\
\text { Aliyah di } \\
\text { Pulau } \\
\text { Bawean }\end{array}$ \\
\hline
\end{tabular}

\section{Definisi Operasional}

Agar memudahkan pemahaman tentang variabel yang akan dikaji dalam penelitian ini, berikut dirumuskan definisi operasional dari variabel penelitian ini, yaitu:

\section{Lingkungan kerja}


Lingkungan kerja adalah segala sesuatu yang ada di sekitar guru dan dapat mempengaruhi dirinya dalam melaksanakan tugas-tugasnya sebagai guru. Dalam penelitian ini lingkungan kerja diukur melalui indikator:

a. Lingkungan kerja fisik

- Sarana dan prasarana

- Kondisi lingkungan

- Keamanan

b. Lingkungan kerja non fisik

- Hubungan kerja dengan atasan

- Hubungan kerja dengan sesama guru

- Hubungan kerja dengan karyawan madrasah

\section{Motivasi kerja}

Motivasi kerja adalah dorongan internal ataupun eksternal yang menambah semangat kerja guru dalam melaksanakan tugas-tugasnya. dalam penelitian ini motivasi kerja diukur melalui:

a. Kebutuhan akan berprestasi

- Mengatur tugas dengan baik

- Meiliki figur

- Menjaga citra

- Berpikir realistis untuk mencapai tujuan

b. Kebutuhan akan kekuasaan

- Mempunyai pengaruh 
- Mengendalikan orang lain

- Suka memberi saran

c. Kebutuhan akan afiliasi

- Ingin diterima orang lain

- Menjaga persahabatan

- Bekerja sama

\section{Kepuasan kerja}

Kepuasan kerja adalah perasaan nyaman dan senang dari guru yang ditunjukkan dalam sikap atau pola perilaku positif yang timbul dari pemenuhan kebutuhan dan pekerjaan yang diharapkan oleh guru. Indikator kepuasan kerja yang dipakai dalam penelitian ini adalah:

a. Upah / gaji

- Wajar dan proporsional

b. Pekerjaan

- Menarik atau menyenangkan

c. Kesempatan promosi

- Kesempatan untuk maju

d. Rekan kerja

- Bersahabat dan mendorong untuk maju

\section{Kinerja Guru}

kinerja guru (performance teacher) ialah keberhasilan guru dalam proses pembelajaran dengan menampilkan kompetensi-kompetensi dimana guru sebagai pendidik dan sekaligus sebagai pengajar. Dalam penelitian ini kinerja 
guru diukur menggunakan instrumen penilaian kinerja guru yang telah ditetapkan.

\section{a. Perencanaan pembelajaran}

- Memformulasikan tujuan pembelajaran dalam RPP dengan memperhatikan karakter peserta didik

- Menyusun bahan ajar secara runut, logis, kontekstual dan mutakhir

- Merencanakan kegiatan pembelajaran yang efektif

- Memilih sumber belajar/ media pembelajaran sesuai dengan materi dan strategi

b. Pelaksanaan kegiatan pembelajaran yang aktif dan efektif

- Memulai pembelajaran dengan efektif

- Menguasai materi pelajaran

- Menerapkan strategi pembelajaran yang efektif

- Memanfaatkan sumber belajar/media

- Memelihara keterlibatan siswa dalam pembelajaran

- Menggunakan bahasa yang benar dan tepat

- Mengakhiri pembelajaran dengan efektif

c. Penilaian pembelajaran

- Merancang alat evaluasi

- Menggunakan berbagai strategi dan metode penilaian

- Memanfaatkan berbagai hasil penilaian untuk memberikan umpan balik bagi peserta didik tentang kemajuan belajarnya. 


\section{BAB II}

\section{KAJIAN PUSTAKA}

\section{A. Lingkungan Kerja}

\section{Pengertian Lingkungan Kerja}

Lingkungan adalah keseluruhan atau setiap aspek dan gejala fisik dan sosial kultural yang mempengaruhi individu. Kerja adalah aktivitas manusia baik fisik maupun mental yang didasarkan adalah bawaan dan mempunyai tujuan yaitu mendapatkan kepuasan ${ }^{25}$. Dengan demikian dapat disimpulkan bahwa lingkungan kerja adalah segala sesuatu yang ada di sekitar para pekerjaan dan yang dapat mempengaruhi dirinya dalam menjalankan tugas-tugas yang dibebankan ${ }^{26}$.

Menurut Serdamayati lingkungan kerja adalah keseluruhan alat perkakas dan bahan yang dihadapi, lingkungan sekitarnya dimana seseorang bekerja, metode kerjanya, serta pengaturan kerjanya baik sebagai perseorangan maupun sebagai kelompok. ${ }^{27}$ Kondisi lingkungan kerja dikatakan baik atau sesuai jika manusia dapat melaksanakan kegiatan secara optimal ,sehat dan nyaman. Kesesuaian lingkungan kerja dapat dilihat akibatnya dalam jangka waktu yang lama, lebih jauh lagi lingkungan kerja yang kurang baik dapat menuntut tenaga kerja dan waktu yang lebih banyak dan tidak mendukung adanya sistem kerja yang efisien.

\footnotetext{
${ }^{25}$ Moh As'ad. Psikologi Industri. (Liberty : Yogyakarta 1995) Hlm. 47

${ }^{26}$ Niti Seminto, S. Alex. 1992. Manajemen Personalia. (Jakarta : Ghalia Indonesia) Hlm. 183

${ }^{27}$ Agni Prasetya, Pengaruh Lingkungan Kerja dan kepuasan kerja terhadap kinerja guru pada SMP Pasundan 6 Bandung dan SMK Pasundan 3 Bandung. Universitas Komputer Indonesia, Hlm. 3
} 
Pendapat lain mengatakan lingkungan kerja adalah keadaan fisik dimana seseorang melakukan tugas kewajiban sehari hari termaksud kondisi ruang yaitu baik dari kantor maupun pabrik. ${ }^{28}$

Lingkungan kerja adalah segala sesuatu yang berada di sekitar para pekerja dan yang dapat mempengaruhi dirinya dalam menjalankan tugastugas yang dibebankan kepadanya. Perusahaan hendaknya dapat mencerminkan kondisi yang mendukung kerja sama antar tingkat atasan, bawahan maupun yang memiliki status jabatan yang sama di perusahaan. Kondisi yang hendaknya diciptakan asalah suasana kekeluargaan, komunikasi yang baik dan pengendalian diri. ${ }^{29}$

Berdasarkan pengertian di atas, dapat di ambil kesimpulan bahwa , lingkungan kerja adalah keadaan fisik seseorang dalam suatu pekerjaannya dapat mempengaruhi pegawai saat menjalankan tugasnya. Lingkungan kerja sebagai sumber informasi dan tempat melakukan aktivitas, maka kondisi lingkungan kerja yang baik harus dicapai agar karyawan merasa betah dan nyaman di dalam ruangan untuk menyelesaikan pekerjaan sehingga dapat efisiensi yang tinggi. Lingkungan kerja yang baik akan membawa dampak pada meningkatnya kualitas pekerjaan, mengurangi ketenangan pada mata dan keinginan rohaniah, serta yang terpenting semangat kerja lebih baik dan prestise yang lebih baik untuk instansi yang bersangkutan.lz

28 Sondang P. Siagian, Kiat Meningkatkan Produktivitas Kerja, (Jakarta: Rineka Jaya, 2002). Hlm. 15

${ }^{29}$ Nitisemito, Alex S. Manajemen Personalia, (Jakarta: Ghalaia Indonesia.2002) 


\section{Jenis - Jenis Lingkungan Kerja}

Sedarmayanti menyatakan bahwa secara garis besarnya, jenis lingkungan kerja terbagi 2 yaitu: lingkungan kerja fisik dan, lingkungan kerja non fisik. ${ }^{30}$

1) Lingkungan kerja fisik

Lingkungan kerja fisik, adalah semua keadaan berbentuk fisik yang terdapat di sekitar tempat kerja yang dapat mempengaruhi karyawan secara langsung maupun tidak langsung. Lingkungan kerja fisik dibagi menjadi 2 kategori yaitu :

a. Lingkungan yang langsung berhubungan dengan karyawan (kursi, meja, dan sebagainya )

b. Lingkungan perantara atau lingkungan umum dapat juga disebut lingkungan kerja yang mempengaruhi kondisi pekerja, misal; temperatur, sirkulasi udara, pencahayaan, kebisingan, getaran mekanis, bau tidak sedap, tata warna, keamanan, dan sebagainya

2) Lingkungan Kerja Non Fisik

Lingkungan Kerja Non Fisik, adalah semua keadaan yang terjadi yang berkaitan dengan hubungan kerja, baik hubungan dengan atasan maupun hubungan sesama rekan kerja ataupun hubungan dengan bawahan.

\footnotetext{
${ }^{30}$ Sedarmayanti, Sumberdaya Manusia dan Produktivitas kerja. (Jakarta: Ilham Jaya, 2001),Hlm.54
} 
Kedua lingkungan kerja tersebut sangat menentukan kinerja dari para karyawan/ karyawati/ guru dan dapat meningkatkan kinerja mereka.. lingkungan fisik terdapat dalam ruangan kerja guru ataupun fasilitas yang di berikan kepada guru dalam mengajar, sedangkan non fisik yaitu lingkungan dengan kerabat guru atau rekan guru dalam mengajar.

\section{Cara Mengukur Lingkungan Kerja}

Kondisi lingkungan yang baik akan menunjang manusia untuk melaksanakan tugas dengan baik pula sehingga dapat mencapai hasil kerja yang optimal. Suatu kondisi lingkungan dikatakan baik atau sesuai apabila manusia dapat melaksanakan kegiatannya secara optimal, sehat, aman, dan nyaman. Dampak dari ketidaksesuaian lingkungan kerja dapat dilihat akibatnya dalam jangka waktu yang relatif lama. Keadaan lingkungan kerja yang kurang baik dapat menuntut tenaga dan waktu yang lebih banyak dan akan berdampak pada sistem kerja yang tidak efektif dan tidak efisien. Banyak faktor yang mempengaruhi terbentuknya suatu kondisi lingkungan kerja.

Berikut ini beberapa faktor yang diuraikan Sedarmayanti yang dapat mempengaruhi terbentuknya suatu kondisi lingkungan kerja dikaitkan dengan kemampuan karyawan, diantaranya adalah: Penerangan/cahaya di tempat kerja, Temperatur/suhu udara di tempat kerja, Kelembaban di tempat kerja, Sirkulasi udara di tempat kerja, Kebisingan di tempat kerja, Getaran mekanis di tempat kerja, Bau tidak sedap di tempat kerja, Tata warna di 
tempat kerja, Dekorasi di tempat kerja, Musik di tempat kerja, Keamanan di tempat kerja. ${ }^{31}$

Sedangkan indikator-indikator yang bisa digunakan dalam mengukur lingkungan kerja menurut Sedarmayanti, adalah: Penerangan, Suhu udara, Suara bising, Penggunaan warna, Ruang gerak yang diperlukan, Keamanan kerja dan hubungan karyawan. ${ }^{32}$

\section{Lingkungan Kerja Dalam Perspektif Islam}

Islam memandang bahwa fasilitas kerja merupakan pemenuhan hakhak dan kebutuhan yang diberikan pemimpin untuk meningkatkan kesejahteraan para pekerjanya. Dengan adanya fasilitas memungkinkan untuk meningkatkan kinerja karyawan guna mencapai tujuan yang telah ditentukan oleh manajemen dengan segala potensi secara efektif dan efisien. Hal tersebut merupakan bentuk penghargaan dan penempatan posisi manusia dalam kemuliaan yang melebihi makhluk yang lainnya. Allah SWT. Berfirman dalam surat Al-Israa' ayat 70:
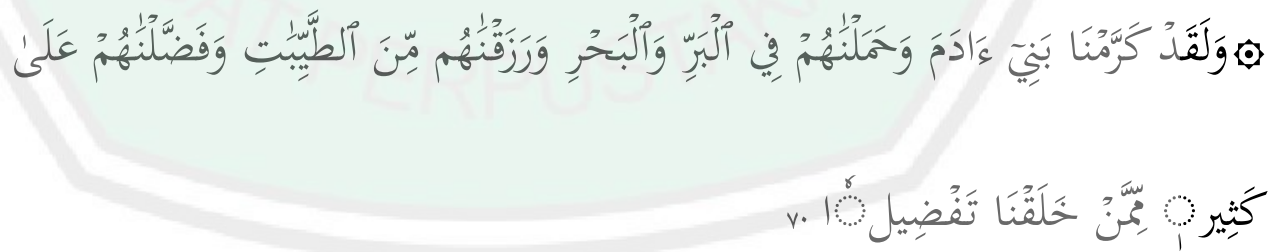

Dan sesungguhnya telah Kami muliakan anak-anak Adam, Kami angkut mereka di daratan dan di lautan, Kami beri mereka rezeki dari yang baikbaik dan Kami lebihkan mereka dengan kelebihan yang sempurna atas kebanyakan makhluk yang telah Kami ciptakan

\footnotetext{
${ }^{31}$ Sedarmayanti, Sumberdaya Manusia dan Produktivitas kerja. (Jakarta: Ilham Jaya, 2001),Hlm.21
}

${ }^{32}$ Sedarmayanti, ,.......Hlm.46 
Ayat di atas menjelaskan bahwa Allah SWT sudah memberi kehidupan pada manusia dengan lingkungan yang indah. Begitu pula bagi para guru, hendaknya di beri fasilitas yang mendukung kinerjanya.

\section{B. Motivasi Kerja}

\section{Pengertian Motivasi Kerja}

Gito Sudarmo dalam Sutrisno menjelaskan, motivasi adalah faktor yang mendorong seseorang untuk melakukan suatu aktivitas, oleh karena itu motivasi sering disebut juga sebagai faktor pendorong perilaku seseorang. Setiap aktivitas yang dilakukan oleh seseorang pasti memiliki suatu faktor yang mendorong aktivitas tersebut. ${ }^{33}$.

Hasibuan dalam Sutrisno juga menjelaskan bahwa motivasi adalah pemberian daya penggerak yang menciptakan gairah kerja bagi seseorang, agar mereka mau bekerja sama, bekerja efektif dan terintegrasi dengan segala daya upayanya untuk mencapai kepuasan. ${ }^{34}$

Motivasi kerja adalah sesuatu yang menimbulkan semangat atau dorongan dan kerja. oleh sebab itu , motivasi kerja dalam psikologi sebagai pendorong semangat kerja. ${ }^{35}$

Menurut motivasi kerja adalah sesuatu yang menimbulkan semangat atau dorongan kerja. Motivasi merupakan pemberian atau penggerak yang menciptakan kegairahan kerja seseorang agar mau bekerja sama bekerja

\footnotetext{
${ }^{33}$ Sutrisno, Edy, “Manajemen Sumber Daya Manusia”, (Jakarta: Kencana,2009)Hlm. 115

${ }^{34}$ Ibid Hlm. 117

${ }^{35}$ Pandji. Anoraga, Psikologi Kerja. (Jakarta.: Rineka Cipta1998) Hlm 35.
} 
secara efektif dan terintegrasi dan segala daya upaya untuk mencapai kepuasan. $^{36}$

Manusia merupakan makhluk sosial yang memiliki kebutuhan, perasaan, pikiran dan motivasi. setiap manusia yang melakukan sesuatu pada dasarnya didorong oleh suatu motivasi. Adanya berbagai kebutuhan akan menimbulkan motivasi seseorang untuk berusaha memenuhi berbagai kebutuhan tersebut dengan bekerja.

Motivasi kerja merupakan kondisi psikologis yang mendorong seseorang atau pegawai untuk melaksanakan usaha atau kegiatan untuk mencapai tujuan organisasi maupun tujuan individual. Dengan demikian disimpulkan bahwa motivasi adalah dorongan yang timbul pada diri seseorang yang menyebabkan ia melakukan sesuatu tindakan tertentu untuk memenuhi kebutuhannya. Jadi motivasi kerja merupakan kondisi psikologis yang mendorong pekerja yang melakukan usaha menghasilkan barang atau jasa sehingga dapat tercapai suatu tujuan.

\section{Teori Kebutuhan McClelland}

Teori motivasi yang dikemukakan oleh McClelland memfokuskan pada tiga kebutuhan dasar manusia, yaitu: (1) kebutuhan akan prestasi, adalah dorongan untuk mengungguli, berprestasi sehubungan dengan seperangkat standar, bergulat untuk sukses, (2) kebutuhan akan kekuasaan, adalah kebutuhan untuk membuat orang lain berperilaku dalam suatu cara yang

\footnotetext{
${ }^{36}$,Moh As'ad. Psikologi Industri. (Liberty : Yogyakarta 1995) Hlm. 45
} 
orang itu (tanpa dipaksa) tidak akan berperilaku demikian, (3) kebutuhan afiliasi, adalah hasrat untuk berinteraksi antar pribadi yang ramah dan akrab. ${ }^{37}$ Pembahasan tentang motivasi kerja guru kiranya lebih tepat bila menggunakan teori kebutuhan yang dikembangkan oleh McClelland

Dari riset mengenai kebutuhan akan prestasi, McClelland mendapatkan bahwa peraih prestasi tinggi membedakan diri mereka dari orang lain oleh hasrat mereka untuk menyelesaikan hal-hal dengan lebih baik. Mereka mencari situasi di mana mereka dapat mencapai tanggung jawab pribadi untuk menemukan pemecahan terhadap problem-problem, di mana mereka dapat menerima umpan balik yang cepat atas kinerja mereka sehingga mereka dapat mengetahui dengan mudah apakah mereka menjadi lebih baik atau tidak, dan di mana mereka dapat menentukan tujuan-tujuan yang cukup menantang ${ }^{38}$

Kebutuhan akan kekuasaan (nPow - need for power) adalah hasrat untuk mempunyai dampak, berpengaruh, dan mengendalikan orang lain. Individu-individu dengan nPow yang tinggi menikmati untuk dibebani, berusaha untuk dapat mempengaruhi orang lain, lebih menyukai ditempatkan di dalam situasi kompetitif dan berorientasi status, dan cenderung lebih peduli akan prestise (gengsi) dan memperoleh pengaruh terhadap orang lain daripada kinerja yang efektif. Lebih lanjut Robbins menjelaskan tentang kebutuhan yang ketiga dari teori McClelland, yaitu

${ }^{37}$ D.C. Mc Clelland, The Achieving Society, (New Jersey: Princeton, D Van Nostrand, 1961), Hlm.. 26.

${ }^{38}$ Robbins, P. Stephen, "Perilaku Organisasi: Konsep, Kontroversi, Aplikasi”, Jilid 1, Edisi Kedelapan, (Jakarta, :PT Prenhallindo, 2001) Hlm. 173 
kebutuhan akan pertalian atau afiliasi ( $n A f f-$ need for affiliation) bahwa individu dengan motif afiliasi yang tinggi berjuang keras untuk persahabatan, lebih menyuai situasi kooperatif daripada situasi kompetitif, dan sangat menginginkan hubungan yang melibatkan derajat pemahaman timbal-balik yang tinggi. ${ }^{39}$

McClelland mengemukakan teori motivasi berhubungan erat dengan konsep belajar. Ia berpendapat bahwa banyak kebutuhan diperoleh dari kebudayaan. Menurutnya, terdapat tiga jenis kebutuhan yaitu: kebutuhan untuk berprestasi, kebutuhan untuk berkuasa, kebutuhan untuk berafiliasi. Kebutuhan akan prestasi, membuat orang mempunyai dorongan yang kuat untuk berhasil. Berprestasi bukan untuk ganjaran.

\section{Faktor Yang Mempengaruhi Tinggi Rendahnya Motivasi Kerja}

Dalam kegiatan administrasi pendidikan motivasi kerja yang tinggi dari setiap personal yang terlibat di dalamnya merupakan faktor yang memuaskan bagi tercapainya tujuan-tujuan pendidikan diantaranya:

a. Minat atau perhatian terhadap pekerjaan berpengaruh terhadap motivasi seseorang merasa bahwa minat atau perhatiannya sesuai dengan jelas sifat dan pekerjaan yang dilakukan maka akan meningkatkan motivasi kerjanya.

b. Faktor upah / gaji yang tinggi dipandang sebagai faktor yang dapat mempertinggi motivasi kerja.

39 Robbins, P. Stephen, "Perilaku Organisasi: Konsep, Kontroversi, Aplikasi”, Jilid 1, Edisi Kedelapan, (Jakarta, :PT Prenhallindo, 2001) Hlm. 174 
c. Faktor status sosial dari pekerjaan dapat mempengaruhi motivasi kerja. Pekerjaan yang mendapat status sosial/posisi yang tinggi atau baik.

d. Faktor suasana kerja dan hubungan kemanusiaan yang lebih sehingga setiap orang merasa diterima dan dihargai dalam kelompoknya dapat mempertinggi motivasi kerja.

\section{Cara Mengukur Motivasi kerja}

Cara-cara pengukuran motivasi kerja telah banyak dikembangkan, diantaranya oleh McClelland yang mengemukakan 6 (enam) karakteristik orang yang mempunyai motivasi berprestasi tinggi yang bisa dijadikan indikator dalam mengukur motivasi kerja, yaitu : (1) Memiliki tingkat tanggung jawab pribadi yang tinggi, (2) Berani mengambil dan memikul resiko, (3) Memiliki tujuan realistik, (4) Memiliki rencana kerja yang menyeluruh dan berjuang untuk merealisasikan tujuan, (5) Memanfaatkan umpan balik yang konkrit dalam semua kegiatan yang dilakukan, dan (6) Mencari kesempatan untuk merealisasikan rencana yang telah diprogramkan. ${ }^{40}$

Sedangkan Edward Murray berpendapat bahwa karakteristik orang yang mempunyai motivasi berprestasi tinggi adalah sebagai berikut: (1) Melakukan sesuatu dengan sebaik-baiknya, (2) Melakukan sesuatu dengan mencapai kesuksesan, (3) Menyelesaikan tugas-tugas yang memerlukan

${ }^{40}$ Anwar Prabu Mangkunegara.. Evaluasi Kinerja. (Bandung : Refika Aditama,2005) Hlm 67 
usaha dan keterampilan, (4) Berkeinginan menjadi orang terkenal dan menguasai bidang tertentu, (5) Melakukan hal yang sukar dengan hasil yang memuaskan, (6) Mengerjakan sesuatu yang sangat berarti, dan (7) Melakukan sesuatu yang lebih baik dari orang lain. ${ }^{41}$

\section{Motivasi Kerja Dalam Perspektif Islam}

Dorongan yang ada pada diri seseorang untuk berprestasi akan menjadikan diri seorang guru untuk mengerjakan tugas dengan baik, dan menjadikan dirinya teladan bagi guru-guru yang lain. Dorongan ini akan memberikan kepuasan bagi diri seorang guru, sehingga guru tersebut dapat merasakan keserasian antara apa yang telah dia kerjakan dengan apa yang telah diharapkan. Dalam Al-Quran disebutkan dalam surah Al-Ankabut ayat 6:

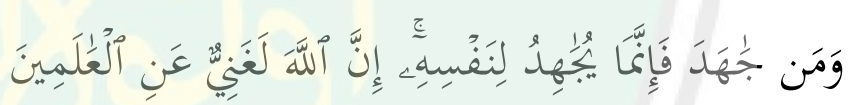

Dan barangsiapa yang berjihad, maka sesungguhnya jihadnya itu adalah untuk dirinya sendiri. Sesungguhnya Allah benar-benar Maha Kaya (tidak memerlukan sesuatu) dari semesta alam

Motivasi dalam diri seorang guru akan menguntungkan guru tersebut dalam melaksanakan tugasnya. Ketika guru termotivasi maka guru akan semakin dekat dengan target pembelajaran, dan tentunya guru akan mampu menggerakkan dan memotivasi siswa dalam belajar. dan hal ini akan menuntun pada terpenuhinya kepuasan guru yang akan berdampak pada

\footnotetext{
${ }^{41}$ Anwar Prabu Mangkunegara......., Hlm 68
} 
meningkatnya kinerja guru dalam mewujudkan pembelajaran yang efektif. Dalam Al-Quran disebutkan dalam surah An-Najm ayat 53:

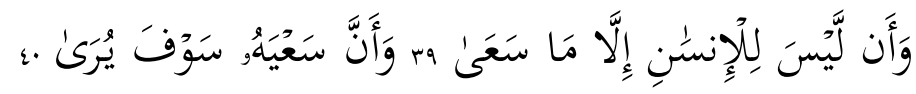

dan bahwasanya seorang manusia tiada memperoleh selain apa yang telah diusahakannya. dan bahwasanya usaha itu kelak akan diperlihatkan (kepadanya)

\section{Kepuasan Kerja Guru}

\section{Pengertian Kepuasan Kerja Guru}

Kepuasan kerja merupakan sifat individual seseorang sehingga seseorang mempunyai tingkat kepuasan berbeda-beda sesuai dengan sistem nilai-nilai yang berlaku pada dirinya. Hal ini disebabkan oleh adanya perbedaan pada masing-masing individu. Semakin banyak aspek-aspek dalam pekerjaan sesuai dengan keinginan individu tersebut. Maka semakin tinggi tingkat kepuasan yang dirasakan dan begitu pula sebaliknya.

Biasanya seseorang akan merasa puas atas kerja yang telah atau sedang dilakukan, apabila apa yang dikerjakan itu dianggapnya telah memenuhi harapannya, sesuai dengan tujuan seseorang tersebut bekerja. Apabila seseorang mendambakan sesuatu maka itu berarti seseorang tersebut memiliki suatu harapan dan dengan demikian ia termotivasi untuk melakukan tindakan ke arah pencapaian harapan tersebut, maka seseorang tersebut akan merasa puas.

Pendapat Wexley dan Yuki mendefinisikan kepuasan kerja is the way an employee fuels about his or her job artinya kurang lebih cara pegawai 
merasakan dirinya atau pekerjaannya. ${ }^{42}$ Berdasarkan pendapat Keith Davis, Wekley dan Yuki tersebut di atas, kepuasan kerja adalah suatu perasaan yang menyokong atau tidak menyokong diri pegawai yang berhubungan dengan pekerjaannya maupun dengan kondisinya.

Menurut Gibson, et. al. kepuasan ,Kepuasan kerja adalah sikap yang dikembangkan para karyawan sepanjang waktu mengenai berbagai segi pekerjaannya, seperti upah, pekerjaan, kesempatan promosi dan rekan kerja. $^{43}$

Menurut Kumar, kepuasan kerja guru merupakan gejala kompleks yang memiliki berbagai faktor yang berhubungan, yaitu personal, sosial, budaya dan ekonomi. ${ }^{44}$ Kepuasan kerja guru juga merupakan hasil dari berbagai sikap seorang guru terhadap pekerjaannya dan terhadap faktor-faktor yang berhubungan dengan pekerjaannya. Kepuasan kerja guru adalah perasaan guru tentang menyenangkan atau tidak mengenai pekerjaan berdasarkan atas harapan guru dengan imbalan yang diberikan oleh sekolah. Kepuasan kerja guru ditunjukkan oleh sikapnya dalam bekerja atau mengajar. Jika guru puas akan keadaan yang mempengaruhi dia, maka dia akan bekerja atau mengajar dengan baik

Kepuasan kerja guru merupakan kondisi emosional guru terhadap aspek-aspek pekerjaannya, yang mana terjadi atau tidak titik temu antara batas jasa guru dengan tingkat nilai balas jasa, baik finansial maupun non

\footnotetext{
${ }^{42}$ Moh As'ad. Psikologi Industri. (Liberty : Yogyakarta 1995) Hlm. 45

${ }^{43}$ Gibson, James L, et. all., “Organisasi: Perilaku Struktur Proses”, Jilid 1, Edisi Kelima, Erlangga, Jakarta, 1985. Hlm. 67

${ }^{44}$ Kumar, Jalaja., Rao, B. D. (2007). Job Satisfaction of Teacher. New Delhi Sachin Printers.
} 
finansial. Kondisi emosional ini dipengaruhi oleh faktor internal dan eksternal dan diwujudkan dalam sikap dan perilaku terhadap pekerjaannya. $^{45}$

Dari pengertian di atas, dapat disimpulkan bahwa kepuasan kerja guru adalah perasaan guru tentang menyenangkan atau tidak mengenai pekerjaannya dan sejauh mana penerimaan dan nilai-nilai seorang guru terhadap aspek-aspek yang ada dalam suatu pekerjaan, dan dapat diambil suatu batasan yang sederhana tentang kepuasan kerja yaitu perasaan seorang karyawan atau guru terhadap pekerjaan. Apabila kepuasan diperoleh melalui pekerjaannya semakin tinggi kepuasan yang dirasakannya, sehingga diharapkan ia akan meningkatkan kemampuannya untuk melaksanakan pekerjaannya.

\section{Faktor yang Mempengaruhi Kepuasan Kerja}

Faktor-faktor yang dapat menentukan kepuasan kerja menurut Harold E. Burt: ${ }^{46}$

a. Faktor hubungan antara karyawan antara lain

1) Hubungan langsung antara pimpinan dan karyawan

2) Faktor psikis dan kondisi kerja

3) Hubungan sosial diantara karyawan

4) Sugesti dari teman bekerja

5) Emosi dan situasi kerja

${ }^{45}$ Barnawi.... Hlm. 136

${ }^{46}$ Pandji.Anoraga, Psikologi Kerja. (Jakarta: Rineka Cipta1998) Hlm. 82 
b. Faktor-faktor individual yaitu yang berhubungan dengan

1) Sikap orang terhadap pekerjaannya

2) Umur atau usia pada saat bekerja

3) Jenis kelamin

c. Faktor-faktor dari luar (ekstern) yaitu hal-hal yang berhubungan dengan

1) Keadaan keluarga karyawan

2) Rekreasi

3) Pendidikan

Sedangkan menurut pendapat Gilmer tentang faktor-faktor yang mempengaruhi kepuasan kerja ${ }^{47}$ adalah sebagai berikut:

a. Kesempatan untuk maju

Dalam masalah ini ada tidaknya kesempatan untuk memperoleh pengalaman dan peningkatan kemampuan selama kerja.

b. Keamanan kerja

Faktor ini sering disebut sebagai penunjang kepuasan kerja, baik bagi karyawan laki-laki maupun perempuan keadaan yang sama sangat mempengaruhi perasaan karyawan selama kerja.

c. Gaji

Gaji atau bisa disebut dengan upah lebih banyak menyebabkan ketidakpuasan, dan jarang orang

${ }^{47}$ Moh As'ad. Psikologi Industri. (Liberty : Yogyakarta 1995) Hlm. 144 
mengekspresikan kepuasan kerjanya dengan jumlah uang yang diperoleh.

\section{d. Perusahaan dan Manajemen}

Perusahaan dan manajemen yang baik adalah yang mampu memberikan situasi dan kondisi kerja yang stabil, faktor ini yang menentukan kepuasan kerja karyawan.

e. Pengawasan (Supervisi)

Bagi bawahan pimpinan dianggap sebagai figur ayah dan sekaligus atasannya. Supervisi yang buruk dapat berakhir obsersi dan furnofer .

Sedangkan menurut Celluci, Anthony J dan David L. De Vries dalam Mas'ud yang meliputi antara lain:

1) Kepuasan terhadap gaji, yaitu senang atau tidak senang karyawan akan gaji yang diterima.

2) Kepuasan dengan promosi, yaitu sikap senang atau tidak senang karyawan akan promosi yang dilakukan perusahaan.

3) Kepuasan terhadap rekan kerja, yaitu sikap senang atau tidak senang karyawan akan dukungan dari rekan kerjanya.

4) Kepuasan terhadap supervisor, yaitu sikap senang atau tidak senang karyawan akan perlakuan dari pimpinan

\section{Cara Mengukur Kepuasan Kerja}

Terdapat berbagai metode dalam pengukuran kepuasan kerja. bisa melalui tanya jawab secara perorangan, dengan angket ataupun dengan 
pertemuan suatu kelompok kerja. Apabila menggunakan tanya jawab sebagai alatnya, maka guru diminta untuk merumuskan tentang perasaannya terhadap aspek-aspek pekerjaan. Cara lain adalah dengan mengamati sikap dan tingkah laku orang tersebut. Apabila metode yang menggunakan metode kuesioner atau angket, maka guru diminta untuk mengisi kuesioner yang berhubungan dengan masalah kepuasan kerja yang meliputi faktor finansial, faktor fisik, faktor sosial dan faktor psikologi, yang dijawab atau diisi sesuai keadaan yang sebenarnya. ${ }^{48}$

Menurut Gibson, terdapat lima hal yang penting berkaitan dengan pengukuran kepuasan kerja yaitu: (1) pembayaran: suatu jumlah yang diterima dan keadaan yang dirasakan dari pembayaran; (2) pekerjaan: sampai sejauh mana tugas kerja dianggap menarik dan memberikan kesempatan untuk belajar dan untuk menerima tanggung jawab; (3) kesempatan promosi: adanya kesempatan untuk maju; (4) penyelia: kemampuan penyelia untuk memperlihatkan ketertarikan dan perhatian kepada pekerja.; (5) rekan sekerja: sampai sejauh mana rekan sekerja bersahabat, kompeten dan mendukung. ${ }^{49}$

\section{Kepuasan Kerja Dalam Perspektif Islam}

Dalam Islam bekerja merupakan salah satu hal yang sangat dianjurkan, karena bekerja merupakan hal mulia dalam pandangan Allah

\footnotetext{
${ }^{48}$ Moh. As'ad . Psikologi Industri. (Liberty : Yogyakarta 1995) Hlm. 111

${ }^{49}$ Gibson, James,L. Organisasi, Perilaku, Struktur dan Proses. Edisi ke-5. Cetakan ke-3.( Penerbit Erlangga: Jakarta. 2000) Hlm 110
} 
SWT. Dalam Al-Quran terdapat banyak ayat yang menganjurkan untuk bekerja yang merupakan dari sumber rezeki untuk dirinya dan keluarga.

Keserasian antara kepribadian dan pekerjaan akan menimbulkan kepuasan kerja. Kepuasan kerja tersebut akan menumbuhkan semangat kerja guru dalam menjalankan tugasnya.

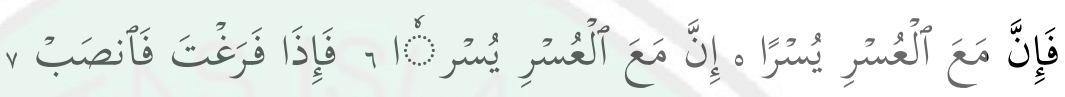

Karena sesungguhnya sesudah kesulitan itu ada kemudahan, sesungguhnya sesudah kesulitan itu ada kemudahan,Maka apabila kamu telah selesai (dari sesuatu urusan), kerjakanlah dengan sungguh-sungguh (urusan) yang lain

ketika pekerjaan yang kita lakukan dengan baik maka akan menimbulkan kepuasan kerja. Kepuasan kerja dalam Islam menekankan pada keseimbangan antara kepuasan jasmani dan rohani.

\section{Kinerja Guru}

\section{Pengertian Kinerja Guru}

Kinerja merupakan tolak ukur keberhasilan individu dalam melakukan suatu pekerjaan atau dalam melaksanakan tugas-tugas yang menjadi tanggung jawabnya. Banyak batasan yang diberikan oleh para ahli mengenai istilah kinerja. Secara prinsip para ahli sepakat bahwa kinerja mengarah pada suatu upaya dalam rangka mencapai prestasi kerja yang lebih baik. Maier sebagaimana dikutip oleh As'ad menjelaskan bahwa 
kinerja merupakan kesuksesan seseorang dalam melaksanakan suatu pekerjaan. $^{50}$

Galton dan Simon mengartikan kinerja atau performance sebagai hasil interaksi atau berfungsinya unsur-unsur motivasi (m), kemampuan (k), dan persepsi (p) pada diri seseorang. Pengertian kinerja ini cenderung melihat kinerja dari sudut pandang faktor-faktor yang mempengaruhinya. Faktorfaktor yang mempengaruhi memiliki sifat perbandingan lurus dalam bentuk perkalian, yaitu antara motivasi, kemampuan dan persepsi. Oleh karena itu, secara matematik semakin besar nilai faktor-faktor yang mempengaruhi, maka semakin tinggi kinerja. ${ }^{51}$

Suprihanto juga menyatakan hal yang sama bahwa kinerja atau prestasi kerja merupakan hasil kerja seorang pegawai selama periode tertentu dibandingkan dengan kemungkinan, misalnya standar, target/sasaran atau kinerja yang telah ditentukan terlebih dahulu dan telah di sepakati bersama. Menurut pandangan ini, kinerja dilihat sebagai hasil kerja dan menghubungkannya dengan standar-standar yang berlaku. Jadi, sebagai tolok ukur kinerja adalah standar kinerja, sehingga kinerja dikatakan baik apabila hasil kerja yang dihasilkan minimal sama atau lebih besar dari standar kinerja yang ditetapkan. ${ }^{52}$

${ }^{50}$ Muhammad As'ad, Psikologi Industri (Yogyakarta: Liberty, 1995), Hlm.. 47

51 Galton, Maurice dan Brian Simon, Progress and Performance in The Primary Classroom, (London: Roultledge dan Kegan Paul, 1994), Hlm. 15

${ }^{52}$ Suprihanto, John, Perilaku Organisasional,( Yogyakarta: Sekolah Tinggi Ilmu Ekonomi YKPN, 2003).Hlm. 33 
Menurut Rashidpoor dalam Digzah et al, Job Performance is a set of behavior wich person show in relation to his job or, in other word, amount of efficiency gained due to the person job type (training, producing or servicing) yang artinya kinerja adalah serangkaian sikap yang ditunjukkan seseorang berkaitan dengan pekerjaannya, atau dengan kata lain kinerja adalah sejumlah efisiensi yang diperoleh karena tipe pekerjaan seseorang (latihan, memproduksi atau melayani). ${ }^{53}$ Demikian ini menjelaskan bahwa kinerja adalah hasil yang dicapai seseorang menurut ukuran yang berlaku untuk pekerjaan yang bersangkutan.

Kinerja guru dapat diartikan sebagai suatu kondisi yang menunjukkan kemampuan seorang guru dalam melaksanakan tugasnya di sekolah dan menggambarkan adanya suatu pembuatan yang di tampilkan guru dalam atau selama melakukan aktivitas pembelajaran. ${ }^{54}$

Menurut Muwahid Sulhan kinerja guru ialah rasa tangungjawab yang dimiliki oleh seorang guru dalam melaksanakan tugas yang diembannya dan juga rasa tangungjawab moral di pundaknya. Hal tersebut dapat dilihat dari kepatuhan dan loyalitas dalam menjalankan tugasnya baik dikelas maupun di luar kelas. Sikap itu diiringi juga dengan rasa tangung jawabnya mempersiapkan perlengkapan pengajaran sebelum melaksanakan proses belajar mengajar, memikirkan strategi dan metodologi yang tepat untuk

\footnotetext{
${ }^{53}$ Morad Razaiei Dizgah. et al, Realetionship between job satisfaction and empoyee job performance in guilan Public sector, Jurnal of Basic and Applied Scientific Research 2(2) 1735- 1741, ISSN 2090-4304, 2012

54 Kompri, Manajemen Pendidikan: Komponen-komponen elementer Kemajuan Sekolah.(Yogyakarta:Ar-Ruzz Media,2015), Hlm..131
} 
digunakan dalam proses belajar mengajar, termasuk juga pemanfaatan media pendidikan serta alat penilaian yang digunakan dalam pelaksanaan evaluasi pembelajaran. ${ }^{55}$

Dapat diambil kesimpulan, kinerja guru (performance teacher) ialah hasil yang dicapai oleh guru dalam melaksanakan tugas-tugas yang dibebankan kepadanya dengan penuh tanggung jawab baik di dalam maupun di luar kelas. Kinerja guru akan baik jika guru melaksanakan tugas dengan penuh tanggung jawab, menguasai dan mengembangkan bahan pelajaran, dan kedisiplinan dalam mengajar.

\section{Faktor-Faktor Yang Mempengaruhi Kinerja Guru}

Kinerja guru dapat dipengaruhi oleh beberapa faktor-faktor tertentu, baik faktor internal maupun eksternal. Faktor internal adalah faktor yang datang dari dalam diri seorang guru, misalnya kemampuan, keterampilan, kepribadian, persepsi, motivasi menjadi guru, pengalaman lapangan dan latar belakang keluarga. Faktor eksternal adalah faktor yang datang dari luar, misalnya gaji, sarana prasarana, lingkungan kerja fisik, dan kepemimpinan. ${ }^{56}$

Pendapat lain yang dikemukakan oleh Surya tentang faktor yang mempengaruhi kinerja guru. ${ }^{57}$ "faktor mendasar yang terkait erat dengan

\footnotetext{
${ }^{55}$ Muwahid Shulhan, Gaya Kepemimpinan Kepala Madrasah Dalam Meningkatkan Kinerja Guru, (Disertasi UIN MALANG.2012), Hlm..102

56 Barnawi \& Mohammad Arifin, Instrumen Pembinaan, Peningkatan, \& penilaian Kinerja Guru Profesional, ( Bandung: Alfabeta, 2011), Hlm..179

57 Surya, M. Psikologi Pembelajaran dan Pengajaran. (Bandung, Pustaka Bani Quraisy: 2004),Hlm.. 10
} 
kinerja profesional guru adalah kepuasan kerja yang berkaitan erat dengan kesejahteraan guru. Kepuasan ini dilatar belakangi oleh faktor-faktor. (1) imbalan, jasa (2) rasa aman, (3) hubungan antar pribadi (4) kondisi lingkungan kerja (5) kesempatan untuk pengembangan dan peningkatan diri."

Berdasarkan faktor-faktor tersebut di atas, faktor yang mempengaruhi kinerja seseorang dapat berasal dari dalam individu itu sendiri maupun dari luar individu itu sendiri, seperti kemampuan, kepuasan kerja, motivasi lingkungan kerja dan gaji.

\section{Cara Mengukur Kinerja}

Penilaian kinerja guru dilaksanakan dengan mengacu kepada tugas utama guru yang meliputi kegiatan merencanakan dan melaksanakan pembelajaran, mengevaluasi dan menilai termasuk di dalamnya menganalisis hasil penilaian dan melaksanakan tindak lanjut hasil penilaian. Berdasarkan tugas utama di atas kemudian dibuat indikator-indikator penilaian kinerja yang dapat terukur sebagai bentuk unjuk kerja guru dalam melaksanakan tugas utamanya tersebut. ${ }^{58}$

Berdasarkan peraturan Menteri Pendidikan Nasional Nomor 16 tahun 2007 tentang standar dan kualifikasi akademik dan kompetensi guru, terdapat 4 (empat) kompetensi yang dinilai dalam penilaian kinerja guru yaitu, kompetensi pedagogik, kepribadian, sosial, dan profesional dengan 14

58 Badan Standar Nasional Pendidikan (BSNP), pedoman pelaksanaan penilaian kinerja guru, (kementerian dan kebudayaan RI, 2012) hlm 5 
(empat belas) subkompetensi sebagaimana yang telah dirumuskan oleh Badan Standar Nasional Pendidikan (BSNP). Berikut ini adalah kisi-kisi penilaian guru yang dikeluarkan oleh Badan Standar Nasional Pendidikan $(\mathrm{BSNP})^{59}$ :

\begin{tabular}{|c|c|}
\hline No. & $\begin{array}{l}\text { DIMENSI TUGAS UTAMA / INDIKATOR KINERJA } \\
\text { GURU }\end{array}$ \\
\hline $\mathrm{I}$ & PERENCANAAN PEMBELAJARAN \\
\hline 1. & $\begin{array}{l}\text { Guru memformulasikan tujuan pembelajaran dalam RPP } \\
\text { sesuai dengan kurikulum/silabus dan memperhatikan } \\
\text { karakteristik peserta didik. }\end{array}$ \\
\hline 2. & $\begin{array}{l}\text { Guru menyusun bahan ajar secara runut, logis, kontekstual } \\
\text { dan mutakhir }\end{array}$ \\
\hline 3. & Guru merencanakan kegiatan pembelajaran yang efektif \\
\hline 4. & $\begin{array}{l}\text { Guru memilih sumber belajar/ media pembelajaran sesuai } \\
\text { dengan materi dan strategi pembelajaran }\end{array}$ \\
\hline II & $\begin{array}{l}\text { PELAKSANAAN KEGIATAN PEMBELAJARAN YANG } \\
\text { AKTIF DAN EFEKTIF }\end{array}$ \\
\hline \multicolumn{2}{|c|}{ A. Kegiatan Pendahuluan } \\
\hline 5. & Guru memulai pembelajaran dengan efektif \\
\hline \multicolumn{2}{|c|}{ B. Kegiatan Inti } \\
\hline 6. & Guru menguasai materi pelajaran. \\
\hline 7. & $\begin{array}{l}\text { Guru menerapkan pendekatan/strategi pembelajaran yang } \\
\text { efektif }\end{array}$ \\
\hline 8. & $\begin{array}{l}\text { Guru memanfaatkan sumber belajar/media dalam } \\
\text { pembelajaran. }\end{array}$ \\
\hline 9. & $\begin{array}{l}\text { Guru memicu dan/atau memelihara keterlibatan siswa dalam } \\
\text { pembelajaran }\end{array}$ \\
\hline 10. & $\begin{array}{l}\text { Guru menggunakan bahasa yang benar dan tepat dalam } \\
\text { pembelajaran }\end{array}$ \\
\hline
\end{tabular}

${ }^{59}$ Badan Standar Nasional Pendidikan (BSNP),.... hlm 6 


\begin{tabular}{|c|l|}
\hline \multicolumn{2}{|l|}{ C. Kegiatan Penutup } \\
\hline 11. & Guru mengakhiri pembelajaran dengan efektif \\
\hline III & PENILAIAN PEMBELAJARAN \\
\hline 12. & $\begin{array}{l}\text { Guru merancang alat evaluasi untuk mengukur kemajuan } \\
\text { dan keberhasilan belajar peserta didik }\end{array}$ \\
\hline 13. & $\begin{array}{l}\text { Guru menggunakan berbagai strategi dan metode penilaian } \\
\text { untuk memantau kemajuan dan hasil belajar peserta didik } \\
\text { dalam mencapai kompetensi tertentu sebagaimana yang } \\
\text { tertulis dalam RPP }\end{array}$ \\
\hline 14. & $\begin{array}{l}\text { Guru memanfaatkan berbagai hasil penilaian untuk } \\
\text { memberikan umpan balik bagi peserta didik tentang } \\
\text { kemajuan belajarnya dan bahan penyusunan rancangan } \\
\text { pembelajaran selanjutnya. }\end{array}$ \\
\hline
\end{tabular}

\section{Kinerja Dalam Perspektif Islam}

Makna kinerja ditinjau dari perspektif Islam, memiliki arti kemauan dan kesungguhan dalam melaksanakan tugas yang dibebankan. Dalam Al-Quran terdapat ayat dan surah yang bisa dijadikan sebagai rujukan atau dalil bagi seorang guru dalam melakukan kinerjanya, salah satunya dalam Al-Quran surah At-Taubah ayat 105, Allah SWT berfirman:

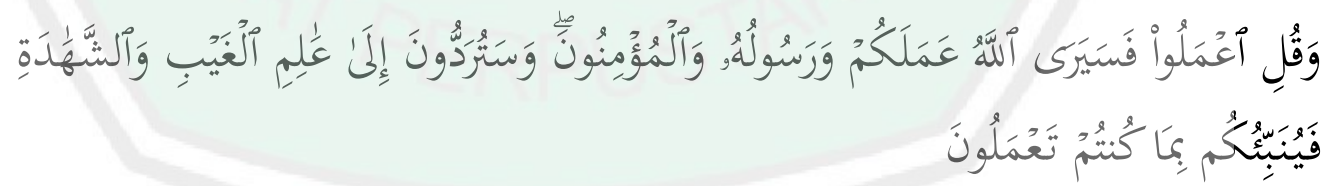

Dan Katakanlah: "Bekerjalah kamu, maka Allah dan Rasul-Nya serta orangorang mukmin akan melihat pekerjaanmu itu, dan kamu akan dikembalikan kepada (Allah) Yang Mengetahui akan yang ghaib dan yang nyata, lalu diberitakan-Nya kepada kamu apa yang telah kamu kerjakan ${ }^{60}$

Selanjutnya dalam surah al-Maidah ayat 35 dijelaskan:

60 Departemen Agama RI, Al-Hidayah: Al-Quran Tafsir Per kata Tajwid Kode Angka (Banten:Kalim) 


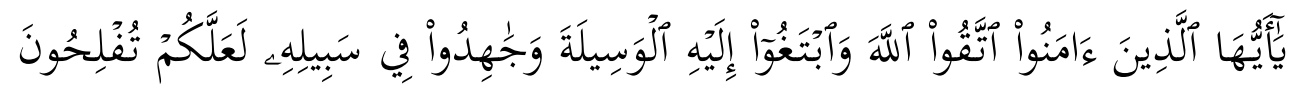

Hai orang-orang yang beriman, bertakwalah kepada Allah dan carilah jalan yang mendekatkan diri kepada-Nya, dan berjihadlah pada jalan-Nya, supaya kamu mendapat keberuntungan

Berdasarkan dua ayat di atas hendaklah guru dalam bekerja dengan ikhlas dan mendidik siswa sesuai dengan kemampuannya. Dalam Islam dianjurkan dalam bekerja untuk bersungguh-sungguh, dan kesungguhan itu dinilai sebagai jihad. Balasan dari kesungguhan ini tidak hanya padangan dan penilaian dari manusia saja namun Allah SWT juga memberikan apresiasi tinggi sebagai orang yang mulia atas kinerjanya dan akan dibalas dengan kemuliaan. Kinerja guru yang baik juga bisa tergambar dari penampilan dan kompetensi yang baik juga.

\section{E. Pengaruh Antar Variabel}

\section{Hubungan Lingkungan Kerja Terhadap Kepuasan Kerja Guru}

Selain kompensasi dan motivasi, lingkungan juga menjadi salah satu hal yang mempengaruhi kepuasan kerja adalah lingkungan kerja. Menurut Samdal dan kawan-kawan dalam Fajar Mayasari juga telah mengidentifikasi tiga aspek lingkungan psikososial organisasi yang menentukan kinerja pegawai. Ketiga aspek tersebut adalah tingkat kepuasan kerja terhadap kinerja, terhadap keinginan pegawai, serta hubungan yang baik dengan sesama pegawai. Mereka juga menyarankan bahwa intervensi organisasi yang meningkatkan rasa kepuasan organisasi akan dapat meningkatkan kinerja organisasi. ${ }^{61}$

\footnotetext{
${ }^{61}$ Fajar mayasari, Pengaruh Kompetensi Dan Lingkungan Kerja Terhadap Kepuasan Kerja Dan Kinerja Guru Di Sd Negeri Kecamatan Gondang Mojokerto, DIE, Jurnal Ilmu Ekonomi \& Manajemen April 2013, Vol. 9 No.2. hal. 137 - 153
} 
Penelitian yang dilakukan oleh Fajar Mayasari menyatakan bahwa ada pengaruh antar variabel dengan hasil estimasi parameter variabel lingkungan kerja terhadap kepuasan kerja berdasarkan indikator - indikatornya menunjukkan hasil yang signifikan 62

$H_{1}=$ Ada pengaruh signifikan lingkungan kerja terhadap kepuasan kerja guru madrasah aliyah di pulau Bawean

\section{Pengaruh Motivasi Terhadap Kepuasan Kerja Guru}

Menurut Radig, dalam Ida Ayu Brahmasari dan Agus Suprayetno, mengatakan bahwa salah satu bentuk motivasi adalah pemberian dorongan, hal itu perlu dilakukan untuk meningkatkan gairah kerja karyawan sehingga dapat mencapai hasil yang diharapkan. Pemberian motivasi kerja yang baik, maka gairah kerja karyawan akan meningkat dan hasil kerja akan optimal sesuai dengan standar kinerja yang ditetapkan. ${ }^{63}$

Penelitian yang dilakukan oleh Sorni Paskah Daeli tentang hubungan kepemimpinan dan motivasi kerja dengan kepuasan kerja menyatakan bahwa Pengaruh kepemimpinan dan motivasi, baik secara parsial maupun secara jamak turut memberikan kontribusi bagi terbentuknya kepuasan kerja pegawai. Dengan kata lain, ada pengaruh positif gaya kepemimpinan terhadap kepuasan

\footnotetext{
${ }^{62}$ Fajar mayasari, Pengaruh Kompetensi Dan Lingkungan Kerja Terhadap Kepuasan Kerja Dan Kinerja Guru Di Sd Negeri Kecamatan Gondang Mojokerto, DIE, Jurnal Ilmu Ekonomi \& Manajemen April 2013, Vol. 9 No.2. hal. 137 - 153

${ }^{63}$ Ida Ayu Brahmasari dan Agus Suprayetno, Pengaruh Motivasi Kerja, Kepemimpinan dan Budaya Organisasi, Terhadap Kepuasan Kerja Karyawan serta Dampaknya pada Kinerja Perusahaan (Studi kasus pada PT. Pei Hai International Wiratama Indonesia) jurnal manajemen dan kewirausahaan, vol.10, no. 2, september 2008: 124-135
} 
kerja pegawai, demikian juga ada pengaruh positif dari pemberian motivasi kerja terhadap kepuasan kerja pegawai. ${ }^{64}$

Hasil penelitian Brahmasari menunjukkan bawa terdapat pengaruh positif signifikansi motivasi kerja, kepemimpinan dan budaya organisasi terhadap kepuasan staf pada kinerja perusahaan. ${ }^{65}$

$H_{2}=$ Ada pengaruh signifikan motivasi kerja terhadap kinerja guru madrasah aliyah di pulau Bawean

\section{Pengaruh Lingkungan Kerja Terhadap Kinerja Guru}

Barry Render \& Jay Heizer menjelaskan bahwa, lingkungan kerja merupakan lingkungan fisik yang berhubungan dengan tempat karyawan bekerja dan dapat mempengaruhi kinerja, keamanan dan mutu kehidupan kerja mereka. Lingkungan kerja yang baik akan memberikan rasa aman dan membuat karyawan bekerja secara optimal yang akan berdampak pada kinerja pegawai akan tinggi. ${ }^{66}$

Penelitian Fajar Maya Sari yang berjudul pengaruh kompetensi dan lingkungan kerja terhadap kepuasan kerja dan kinerja guru juga telah mengidentifikasi tiga aspek lingkungan psikososial organisasi yang menentukan kinerja pegawai. Ketiga aspek tersebut adalah tingkat kepuasan kerja terhadap kinerja, terhadap keinginan pegawai, serta hubungan yang baik

\footnotetext{
${ }^{64}$ Sornih paskah daeli, hubungan kepemiminan dan motivasi kerja dengan kepuasan kerja. Badan penelitian dan pengembangan kementerian dalam negeri

${ }^{65}$ Ida Ayu Brahmasari, pengaruh variabel budaya perusahaan terhadap komitmen karyawan dan kinerja perusahaan kelompok penerbitan Pers jawa pos , disertasi (surabaya: Universitas Airlangga Surabay, 2004)

${ }^{66}$ Barry, Render dan Jay Heizer. Prinsip-prinsip Manajemen Operasi :Operations Management. (Jakarta : Salemba Empat. 2001.) hlm 239
} 
dengan sesama pegawai. Mereka juga menyarankan bahwa intervensi organisasi yang meningkatkan rasa kepuasan organisasi akan dapat meningkatkan kinerja organisasi. ${ }^{67}$

Seperti telah diuraikan di atas bahwa lingkungan kerja sebagai tempat bekerja yang merupakan segala sesuatu yang berada disekitar para pekerja/ karyawan/ pegawai pada saat mereka bekerja tentulah sangat berpengaruh kepada kinerja mereka Lingkungan kerja, baik yang bersifat fisik seperti lingkungan yang langsung kepada guru (kursi, meja, dan sebagainya) dan lingkungan perantara (temperatur, sirkulasi udara, kebisingan, tata warna, bau, keamanan, dan sebagainya), maupun lingkungan yang non fisik atau semua keadaan yang terjadi yang berkaitan dengan hubungan kerja, baik hubungan dengan atasan maupun hubungan dengan sesama rekan kerja atau hubungan kerja dengan bawahan, sangat menentukan kinerja.

$H_{3}=$ Ada pengaruh signifikan lingkungan kerja terhadap kepuasan kerja guru madrasah aliyah di pulau bawean

\section{Pengaruh Motivasi Terhadap Kinerja Guru}

Sujak dalam Ida Ayu Brahmasari dan Agus Suprayetno,, menjelaskan bahwa motivasi bisa berasal dari dalam diri karyawan maupun yang berasal dari lingkungan sekitar, yang akan berdampak pada peningkatan kinerja. Dalam hal ini seorang manajer perlu mengarahkan motivasi dengan menciptakan iklim organisasi yang baik melalui pembentukan budaya kerja

${ }^{67}$ Fajar Maya Sari, Pengaruh Kompetensi Dan Lingkungan Kerja Terhadap Kepuasan Kerja Dan Kinerja Guru DIE, Jurnal Ilmu Ekonomi \& Manajemen. Vol. 9 No.2. 
yang baik, sehingga para karyawan merasa terpacu untuk bekerja lebih keras agar kinerja yang dicapai juga tinggi. ${ }^{68}$

Penelitian tentang motivasi berprestasi dengan kinerja yang dilakukan oleh Kristian terhadap dosen IKIP Negeri menunjukkan bahwa motivasi mempunyai pengaruh yang berarti terhadap sikap mengajar. ${ }^{69}$

Motivasi kerja mempunyai hubungan yang erat dengan kinerja, hal tersebut sesuai dengan yang diungkapkan Maslow dalam Patricia Buhler, bahwa individu yang mempunyai motivasi yang tinggi akan melaksanakan pekerjaannya dengan maksimal, dan hal tersebut menunjukkan bahwa tingkat kinerjanya tinggi sehingga mempengaruhi hasil yang ingin dituju. ${ }^{70}$

Seorang guru yang memiliki motivasi kerja akan mampu mempengaruhi siswa sebagaimana yang diungkap oleh Elliot dalam M. Kharis Fadillah yang menjelaskan bahwa seorang guru yang berperilaku positif cenderung mempunyai siswa yang berprestasi tinggi dan memiliki keterampilan yang positif dalam mengerjakan tugas. ${ }^{71}$

$H_{4}=$ Ada pengaruh signifikan Motivasi kerja terhadap kepuasan kerja guru madrasah aliyah di pulau Bawean

\footnotetext{
${ }^{68}$ Ida Ayu Brahmasari dan Agus Suprayetno, Pengaruh Motivasi Kerja, Kepemimpinan dan Budaya Organisasi, Terhadap Kepuasan Kerja Karyawan serta Dampaknya pada Kinerja Perusahaan (Studi kasus pada PT. Pei Hai International Wiratama Indonesia) jurnal manajemen dan kewirausahaan, vol.10, no. 2, september 2008: 124-135

${ }^{69}$ Kristian, Pengaruh Metode Mengajar dan Motivasi Berprestasi terhadap Perolehan Ilmu Ukur Tanah Mahasiswa FPTK IKIP. (Malang: PPs IKIP Malang, 1995), tesis tidak dipublikasikan, hlm 173.

${ }^{70}$ Patricia Bahler, Alpha Teach Your Self; Management skills dalam 24 jam. Penerjemah Sugeng Haryanto dkk, (Jakarta: Prenada media gruop, 2004), hlm. 192

${ }^{71}$ M. Kharis Fadillah, Pengaruh Keefektifan kepemimpinan, Budaya Organisasi, Motivasi Kerja, Komitmen Organisasi Dan Kepuasan Kerja Terhadap Kinerja Guru Madrasah Aliyah Negeri Di Malang Raya. (Malang: PPS Universitas Islam Negeri Malang 2016): Disertasi tidak diterbitkan
} 


\section{Pengaruh Kepuasan Kerja Terhadap Kinerja Guru}

Menurut Gibson, terdapat dua sisi dalam hubungan timbal balik antara kepuasan dan kinerja. Di satu sisi dikatakan kepuasan kerja ids menyebabkan peningkatan kinerja sehingga pekerja yang puas akan lebih produktif. Pada sisi yang lain kepuasan kerja dapat terjadi karena disebabkan oleh adanya kinerja atau prestasi kerja sehingga pekerja yang lebih produktif akan mendapatkan kepuasan. $^{72}$

Kepuasan kerja dengan kinerja mempunyai hubungan yang emperis, dalam kinerja secara organisasional bukan kinerja secara individual,. Meskipun kinerja secara individual dapat meningkatkan kinerja organisasional, tidak menutup kemungkinan keduanya bertentangan. ${ }^{73}$ Sementara penelitian yang dilakukan Masrukhin dan Waridin menunjukkan ada hubungan yang signifikan antara kepuasan kerja dan kinerja karyawan. ${ }^{74}$

Penelitian yang dilakukan oleh Rinduan Zain, dkk yang berjudul "Pengaruh Kompensasi dan Kepuasan Kerja terhadap Kinerja Dosen Fakultas Ilmu Tarbiyah dan Keguruan UIN Sunan Kalijaga” . adapun Hasil dari analisis korelasi bivariat, variabel kepuasan kerja berkorelasi secara signifikan terhadap kinerja dosen pada angka kepercayaan 95\%, maka ada korelasi positif antara

kepuasan kerja dengan kinerja dosen, sekalipun tingkat hubungan kedua

\footnotetext{
${ }^{72}$ Gibson, James,L. Organisasi, Perilaku, Struktur dan Proses. Edisi ke-5. Cetakan ke-3.( Penerbit Erlangga: Jakarta. 2000) Hlm 110

${ }^{73}$ C. Ostroff, The relationship between satisfiction, attitudes, and performance: an organizational level analysis journal of appliyed psychology,77(6): 1992) hlm 963-974

74 Masrukhin dan Waridin, pengaruh motivasi kerja, kepuasan kerja, budaya organisasi dan kepemimpinan terhadap kinerja pegawa, jurnal ekonomi \& bisnis , vol 7, No.2,(2006)
} 
variabel tersebut adalah sedang. Artinya, semakin tinggi kepuasan kerja dosen maka semakin tinggi pula kinerja dosen. ${ }^{75}$

$H_{5=}$ Ada pengaruh signifikan kepuasan kerja terhadap kinerja guru madrasah aliyah di pulau Bawean

\section{Pengaruh Tidak Langsung Lingkungan Kerja Terhadap Kinerja Guru}

\section{Melalui Kepuasan Kerja Guru}

Menurut Samdal dan kawan-kawan, dalam Fajar Mayasari, menjelaskan bahwa ada tiga aspek lingkungan psikososial organisasi yang menentukan kinerja pegawai. Ketiga aspek tersebut adalah tingkat kepuasan kerja terhadap kinerja, terhadap keinginan pegawai, serta hubungan yang baik dengan sesama pegawai. Mereka juga menyarankan bahwa intervensi organisasi yang meningkatkan rasa kepuasan organisasi akan dapat meningkatkan kinerja organisasi.

Hasil penelitian Hesti Ruscahyono menunjukkan ada pengaruh tidak langsung dari lingkungan kerja terhadap kinerja melalui kepuasan kerja, relatif kecil jika dibandingkan dengan hubungan langsung antar kedua variabel tersebut. $^{76}$

$H_{6=}$ Ada pengaruh tidak langsung lingkungan kerja terhadap kinerja guru melalui kepuasan kerja guru madrasah aliyah di pulau Bawean

\footnotetext{
${ }^{75}$ Riduan, zain. pengaruh kompensasi dan kepuasan kerja terhadap kinerja dosen di fakultas ilmu tarbiyah dan keguruan uin sunan kalijaga yogyakarta. Manageria: Jurnal Manajemen Pendidikan Islam Volume 2, Nomor 1, Mei 2017/1438

${ }^{76}$ Hesthi Ruscahyono, pengaruh locus of control dan lingkungan kerja terhadap kinerja guru smkn 4 klaten dengan kepuasan kerja sebagai intervening, Aktual edisi Pebruari 2014. Vol.1. No.2
} 


\section{Pengaruh Tidak Langsung Motivasi Kerja Terhadap Kinerja Guru}

\section{Melalui Kepuasan Kerja Guru}

Menciptakan kepuasan kerja karyawan bukanlah perkara mudah karena kepuasan kerja dapat tercipta jika variabel-variabel yang mempengaruhinya antara lain motivasi kerja dilakukan dengan baik dan diterima oleh semua karyawan di dalam suatu organisasi/perusahaan. Gibson dalam Ida Ayu Brahmasari dan Agus Suprayetno, mengatakan bahwa kinerja individu akan memberikan kontribusi pada kinerja organisasi, artinya bahwa perilaku anggota organisasi baik secara individu maupun kelompok memberikan kekuatan atas kinerja organisasi sebab motivasinya akan mempengaruhi pada kinerja organisasi. $^{77}$

Hasil penelitian Ida Ayu Brahmasari dan Agus Suprayetno menjelaskan bahwa ada pengaruh antara motivasi kerja terhadap kinerja karyawan, namun tidak signifikan

$$
H_{7}=\text { ada pengaruh tidak langsung motivasi kerja terhadap kinerja guru }
$$
melalui kepuasan kerja guru madrasah aliyah di pulau bawean

\footnotetext{
${ }^{77}$ Ida Ayu Brahmasari dan Agus Suprayetno, Pengaruh Motivasi Kerja, Kepemimpinan dan Budaya Organisasi, Terhadap Kepuasan Kerja Karyawan serta Dampaknya pada Kinerja Perusahaan (Studi kasus pada PT. Pei Hai International Wiratama Indonesia) JURNAL MANAJEMEN DAN KEWIRAUSAHAAN, VOL.10, NO. 2, SEPTEMBER 2008: 124-135
} 


\section{BAB III}

\section{METODE PENELITIAN}

\section{H.Pendekatan Dan Jenis Penelitian}

Pendekatan yang digunakan dalam penelitian ini adalah pendekatan kuantitatif. Penelitian kuantitatif merupakan proses menemukan pengetahuan menggunakan data berupa angka sebagai alat menganalisa dan bertujuan untuk menyusun ilmu pengetahuan dan hukum-hukum dari generalisasinya ${ }^{78}$.

Sifat penelitian ini adalah bersifat korelasi yaitu penelitian yang dilakukan untuk mengetahui hubungan antara dua variabel atau lebih, tanpa ada tambahan atau manipulasi terhadap data yang telah ada. ${ }^{79}$

Tujuan teknik korelasional ini adalah: (1) mencari bukti sesuai hasil pengumpulan data, terdapat pengaruh antar variabel atau tidak, (2) menjawab pertanyaan apakah pengaruh antar variabel kuat, sedang atau lemah, dan (3) untuk memperoleh kepastian secara matematis apakah pengaruh antar variabel signifikan atau tidak. ${ }^{80}$

Penelitian ini menganalisis pengaruh lingkungan kerja $\left(\mathrm{X}_{1}\right)$ dan Motivasi $\left(\mathrm{X}_{2}\right)$ terhadap Kepuasan kerja (Z) serta dampaknya terhadap kinerja guru (Y), keempat variabel tersebut selanjutnya dijabarkan dalam beberapa sub variabel dan dari sub variabel dijabarkan berapa indikator berdasarkan teori yang

\footnotetext{
${ }^{78}$ Moh. Kasiram , Metodelogi Penelitian Kualitatif-Kuantitatif(Malang: Uin Malang Press, 2008),Hlm 149

${ }^{79}$ Suharsimi Arikunto, Prosedur penelitian: Suatu Pendekatan Praktek (Jakarta: Rineka cipta 2006),Hlm 11

${ }^{80}$ Anas Sudijono , pengantar statistik Pendidikan,( Jakarta : Raja Grafindo Persada:2004) Hlm 188
} 
dikemukakan para ahli. Secara ringkas, model konseptual yang digunakan dalam penelitian ini dapat dilihat pada Gambar 3.1 berikut ini:

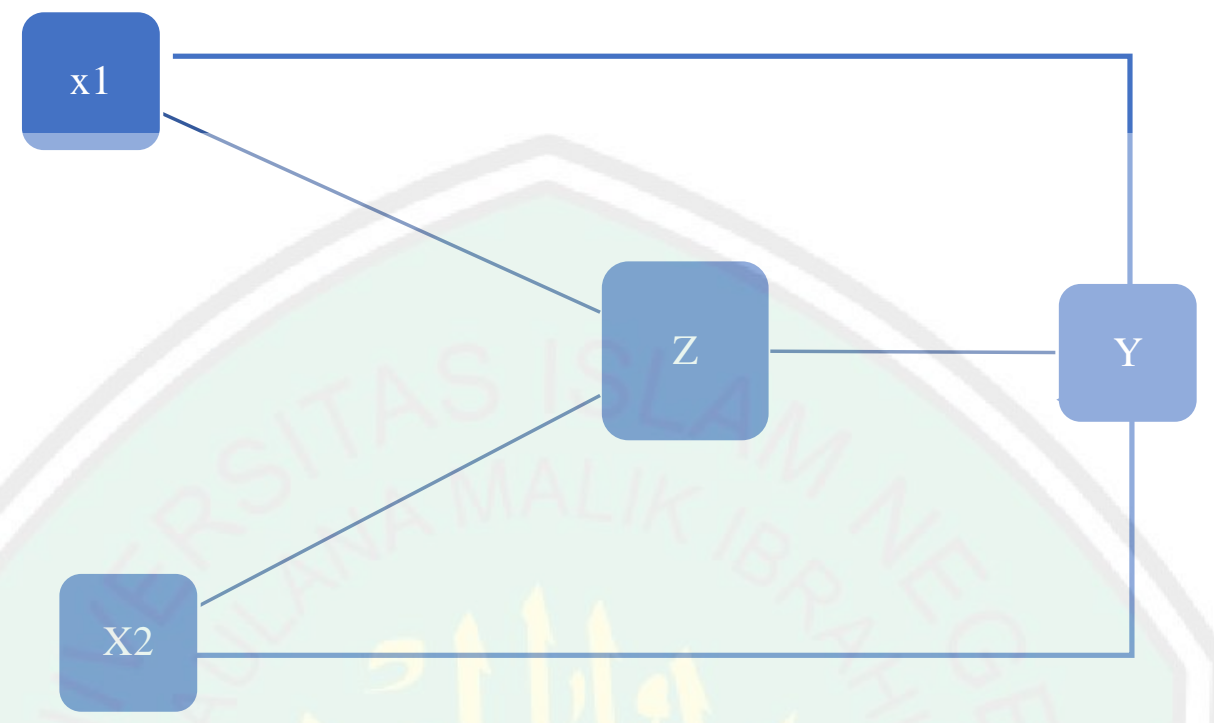

Gambar 3.1 konsep penelitian

\section{Variabel Penelitian}

Penelitian ini terdiri dari empat variabel, dengan rincian: dua variabel independent $(\mathrm{X})$, satu variabel dependent $(\mathrm{Y})$, dan satu variabel intervening $(\mathrm{Z})$. Dari keempat variabel tersebut selanjutnya dijabarkan dalam beberapa sub variabel dan dijabarkan dalam beberapa indikator sesuai dengan teori yang dikemukakan para ahli.

\section{J. Populasi Dan Sampel}

Populasi dalam penelitian ini adalah semua guru madrasah aliyah yang ada di Pulau Bawean, sehingga bisa dikatakan subjek penelitian seluruh guru MA di Pulau Bawean.

Agar mempermudah dalam pengambilan data maka sampel yang akan kita ambil nanti berasal dari lima madrasah aliyah yang merupakan sekolah-sekolah 
unggulan di Pulau Bawean. jumlah sampel yang akan diambil oleh peneliti di sini berjumlah 100 sampel.

\section{K. Pengumpulan Data}

Data yang akan diambil dalam penelitian ini adalah berupa data primer sedangkan metode pengumpulan data dilakukan dengan kuisioner yang diberikan kepada responden secara langsung. Penyebaran angket selaras dengan tujuan mencari infomasi yang detail mengenai suatu masalah dari responden, tanpa adanya rasa khawatir apabila responden memberikan jawaban yang tidak sesuai dengan kenyataan dalam pengisian daftar pernyataan.$^{81}$

Pengumpulan data ini menggunakan angket dengan skala likert berupa butirbutir pernyataan positif dan negatif. Pengumpulan data berupa daftar pernyataan yang disodorkan kepada penulis. ${ }^{82}$

\section{Instrumen penelitian}

Instrumen penelitian ini berupa angket yang diberikan langsung kepada responden untuk dijawab sesuai karakteristik dirinya, sedangkan pengambilan data dilakukan dengan memilih salah satu dari lima alternatif jawaban:

Tabel 3.1: Alternatif jawaban

\begin{tabular}{|c|l|c|}
\hline No. & Alternatif jawaban & Nilai \\
\hline 1 & Sangat setuju & 5 \\
\hline 2 & Setuju & 4 \\
\hline 3 & Ragu-Ragu & 3 \\
\hline
\end{tabular}

${ }^{81}$ Riduwan, skala pengukuran variabel-variabel penelitian (Bandung: Alfabeta, 2008 ), hal 25

${ }^{82}$ Moh. Kasiram , Metodelogi Penelitian Kualitatif-Kuantitatif(Malang: Uin Malang Press,2008),Hlm 149 


\begin{tabular}{|c|l|l|}
\hline 4 & Tidak setuju & 2 \\
\hline 5 & Sangat tidak setuju & 1 \\
\hline
\end{tabular}

\section{Adapun langkah penyusunan angket dilakukan sebagai berikut:}

1. Penyusunan kisi-kisi angket

Kisi-kisi disusun dalam bentuk matrik yang di dalamnya terdapat konsep lingkungan kerja, motivasi kerja, kompensasi, kepuasan kerja dan kinerja guru. Konsep tersebut dijabarkan melalui variabel dan indikator. Masing-masing indikator terwakili oleh item-item angket sebagai alat ukur. Setelah kisi-kisi dibuat barulah menyusun item-item angket .

2. Penyusunan item angket

Item angket disusun berdasarkan kisi-kisi yang telah dibuat mengacu pada lima variabel yang digunakan yaitu lingkungan kerja, motivasi kerja, kompensasi, kepuasan kerja dan kinerja.

Cara yang digunakan untuk menentukan skor dalam penelitian ini dengan menggunakan skala likert yaitu skala yang digunakan untuk mengukur sikap, pendapat, persepsi seseorang atau kelompok tentang fenomena sosial. Jawaban dar setiap item instrumen memiliki gradasi dari positif sampai negatif. Yang berupa kata-kata seperti: selalu, sering, kadang-kadang, jarang, dan tidak pernah dalam skala satu sampai lima.

Adapun pengembangan instrumen untuk masing-masing variabel penelitian adalah sebagai berikut:

a. Angket tentang variabel lingkungan kerja, sub variabel yaitu: (1)lingkungan fisik, (2) lingkungan non fisik 
b. Angket tentang variabel motivasi, sub variabel (1)kebutuhan akan berprestasi (2) kebutuhan akan kekuasaan, (3) kebutuhan akan afiliasi

c. Angket tentang variabel kepuasan kerja, sub variabelnya sebagai berikut: (1)Upah,(2) Pekerjaan (3)kesempatan kerja(4)rekan kerja

d. Angket tentang variabel kinerja guru sub variabel yaitu:(1) perencanaan pembelajaran, (2) pelaksanaan kegiatan pembelajaran yang aktif dan efektif, (3) penilaian pembelajaran

3. Pemberian skor

Pemberian skor angket diawali dengan pemberian kode terhadap jawaban responden. Pemberian kode atas jawaban responden dengan menggunakan kriteria berikut: selalu, sering, jarang, kadang-kadang, dan tidak pernah. Besar skor masing-masing adalah selalu dengan nilai 5, sering dengan nilai 4, kadang-kadang dengan nilai 3, jarang dengan nilai 2, dan tidak pernah dengan nilai 1. Dalam menentukan pilihannya responden dengan alternatif jawaban terhadap item yang bersangkutan yaitu: (1) selalu, artinya pernyataan yang digambarkan selalu terjadi dengan presentase 100\% terjadi, (2) sering, artinya pernyataan yang digambarkan sering terjadi dengan presentase $75 \%$ terjadi, (3) kadang-kadang, artinya pernyataan yang digambarkan kadangkadang terjadi dengan presentase 50\% terjadi, (4) jarang, artinya pernyataan yang digambarkan jarang terjadi dengan presentase $25 \%$ terjadi, (5) tidak pernah, artinya pernyataan yang digambarkan jarang terjadi dengan presentase $0 \%$ terjadi. 
Instrumen yang digunakan untuk mengambil data penelitian ini harus memenuhi dua syarat yaitu valid dan reliabel. Oleh karena itu, sebelum instrumen tersebut digunakan untuk mengambil data maka terlebih dahulu instrumen harus diuji coba. Uji coba ini bertujuan untuk menentukan validitas dan realibilitasnya serta mengetahui tingkat pemahaman responden.

Tabel 3.2: Variabel dan indikator

\begin{tabular}{|c|c|c|c|c|c|}
\hline $\begin{array}{l}\text { No } \\
\cdot\end{array}$ & Variabel & $\begin{array}{l}\text { Sub } \\
\text { variabe } \\
\text { l }\end{array}$ & indikator & $\begin{array}{l}\text { No. butir } \\
\text { instrumen }\end{array}$ & $\begin{array}{l}\text { Jum } \\
\text { lah }\end{array}$ \\
\hline \multirow[t]{2}{*}{1} & \multirow[t]{2}{*}{$\begin{array}{l}\text { Lingkunga } \\
\mathrm{n} \text { kerja } \\
\text { (sedarmay } \\
\text { anti, 2001) }\end{array}$} & $\begin{array}{l}\text { Lingku } \\
\text { ngan } \\
\text { Fisik }\end{array}$ & $\begin{array}{l}\text { - Sarana } \\
\text { prasarana } \\
\text { - Kondisi } \\
\text { lingkungan } \\
\text { - Keamanan }\end{array}$ & $1,2,3$ & 3 \\
\hline & & $\begin{array}{l}\text { Lingku } \\
\text { ngan } \\
\text { non } \\
\text { fisik }\end{array}$ & $\begin{array}{l}\text { - Hubungan } \\
\text { kerja } \\
\text { dengan atasan } \\
\text { - Hubungan } \\
\text { kerja } \\
\text { dengan sesama } \\
\text { guru } \\
\text { - Hubungan } \\
\text { kerja } \\
\text { dengan } \\
\text { karyawan }\end{array}$ & $4,5,6$ & 3 \\
\hline \multirow[t]{3}{*}{2} & \multirow[t]{3}{*}{$\begin{array}{l}\text { Motivasi } \\
\text { kerja } \\
\text { (McClellan } \\
\text { d,1961) }\end{array}$} & $\begin{array}{l}\text { Kebutuh } \\
\text { an akan } \\
\text { berprest } \\
\text { asi }\end{array}$ & $\begin{array}{l}\text {-Mengatur tugas } \\
\text { dengan baik } \\
\text { - Memiliki figur } \\
\text { - Menjaga citra } \\
\text {-Berpikir } \\
\text { realistis untuk } \\
\text { mencapai tujuan }\end{array}$ & $7,8,9,10$ & 4 \\
\hline & & $\begin{array}{l}\text { Kebutuh } \\
\text { an akan } \\
\text { kekuasa } \\
\text { an }\end{array}$ & $\begin{array}{l}\text {-Mempunyai } \\
\text { pengaruh } \\
\text {-Mengendalikan } \\
\text { orang lain } \\
\text { - Suka memberi } \\
\text { saran }\end{array}$ & $11,12,13$ & 3 \\
\hline & & $\begin{array}{l}\text { Kebutuh } \\
\text { an akan } \\
\text { afiliasi }\end{array}$ & $\begin{array}{l}\text {-Ingin diterima } \\
\text { orang lain } \\
\text {-Menjaga } \\
\text { persahabatan }\end{array}$ & $14,15,16$ & 3 \\
\hline
\end{tabular}




\begin{tabular}{|c|c|c|c|c|c|}
\hline & & & - Bekerjasama & & \\
\hline \multirow[t]{4}{*}{3} & \multirow{4}{*}{$\begin{array}{l}\text { Kepuasan } \\
\text { kerja } \\
\text { (Gibson,et } \\
\text {,al, 1985) }\end{array}$} & Upah & $\begin{array}{l}\text {-wajar dan } \\
\text { proporsional }\end{array}$ & 17 & 1 \\
\hline & & $\begin{array}{l}\text { Pekerja } \\
\text { an }\end{array}$ & $\begin{array}{l}\text {-menarik atau } \\
\text { menyenangkan }\end{array}$ & 18 & 1 \\
\hline & & $\begin{array}{l}\text { Kesem } \\
\text { patan } \\
\text { Promos } \\
\text { i }\end{array}$ & $\begin{array}{l}\text {-Kesempatan } \\
\text { maju }\end{array}$ & 19 & 1 \\
\hline & & $\begin{array}{l}\text { Rekan } \\
\text { kerja }\end{array}$ & $\begin{array}{l}\text {-bersahabat } \\
\text { dan } \\
\text { mendorong }\end{array}$ & 20 & 1 \\
\hline 4 & \multirow[t]{2}{*}{$\begin{array}{l}\text { Kinerja } \\
\text { (Pedoman } \\
\text { Pelaksanaa } \\
\text { n Penilaian } \\
\text { Kinerja } \\
\text { Guru (Tim } \\
\text { Badan } \\
\text { PSDMP } \\
\text { dan PMP, } \\
\text { Tim } \\
\text { Direktorat } \\
\text { Profesi } \\
\text { Pendidik } \\
\text { Dirjen } \\
\text { PMPTK } \\
\text { Kementrian } \\
\text { Pendidikan } \\
\text { dan } \\
\text { Kebudayaa } \\
\text { n 2012) ) }\end{array}$} & $\begin{array}{l}\text { Perenca } \\
\text { naan } \\
\text { pembel } \\
\text { ajaran }\end{array}$ & $\begin{array}{l}\text { - } \\
\text { memformulasi } \\
\text { kan tujuan } \\
\text { pembelajaran } \\
\text { dalam RPP } \\
\text { dengan } \\
\text { memperhatikan } \\
\text { karakter peserta } \\
\text { didik } \\
\text {-Menyusun ajar } \\
\text { bahan runut, } \\
\text { secara ro } \\
\text { logis, } \\
\text { kontekstual dan } \\
\text { mutakhir } \\
\text {-Merencanakan } \\
\text { kegiatan } \\
\text { pembelajaran } \\
\text { yang efektif } \\
\text {-Memilih } \\
\text { sumber belajar/ } \\
\text { media } \\
\text { pembelajaran } \\
\text { sesuai dengan }\end{array}$ & $\begin{array}{l}21,22,23,2 \\
4\end{array}$ & 4 \\
\hline & & $\begin{array}{l}\text { Pelaksa } \\
\text { naan } \\
\text { kegiata } \\
\text { n } \\
\text { pembel } \\
\text { ajaran }\end{array}$ & $\begin{array}{l}\text {-Memulai } \\
\text { pembelajaran } \\
\text { dengan efektif } \\
\text {-Menguasai } \\
\text { materi pelajaran } \\
\text {-Menerapkan } \\
\text { strategi } \\
\text { pembelajaran } \\
\text { yang efektif }\end{array}$ & $\begin{array}{l}25,26,27,2 \\
8,29,30,31\end{array}$ & 7 \\
\hline
\end{tabular}




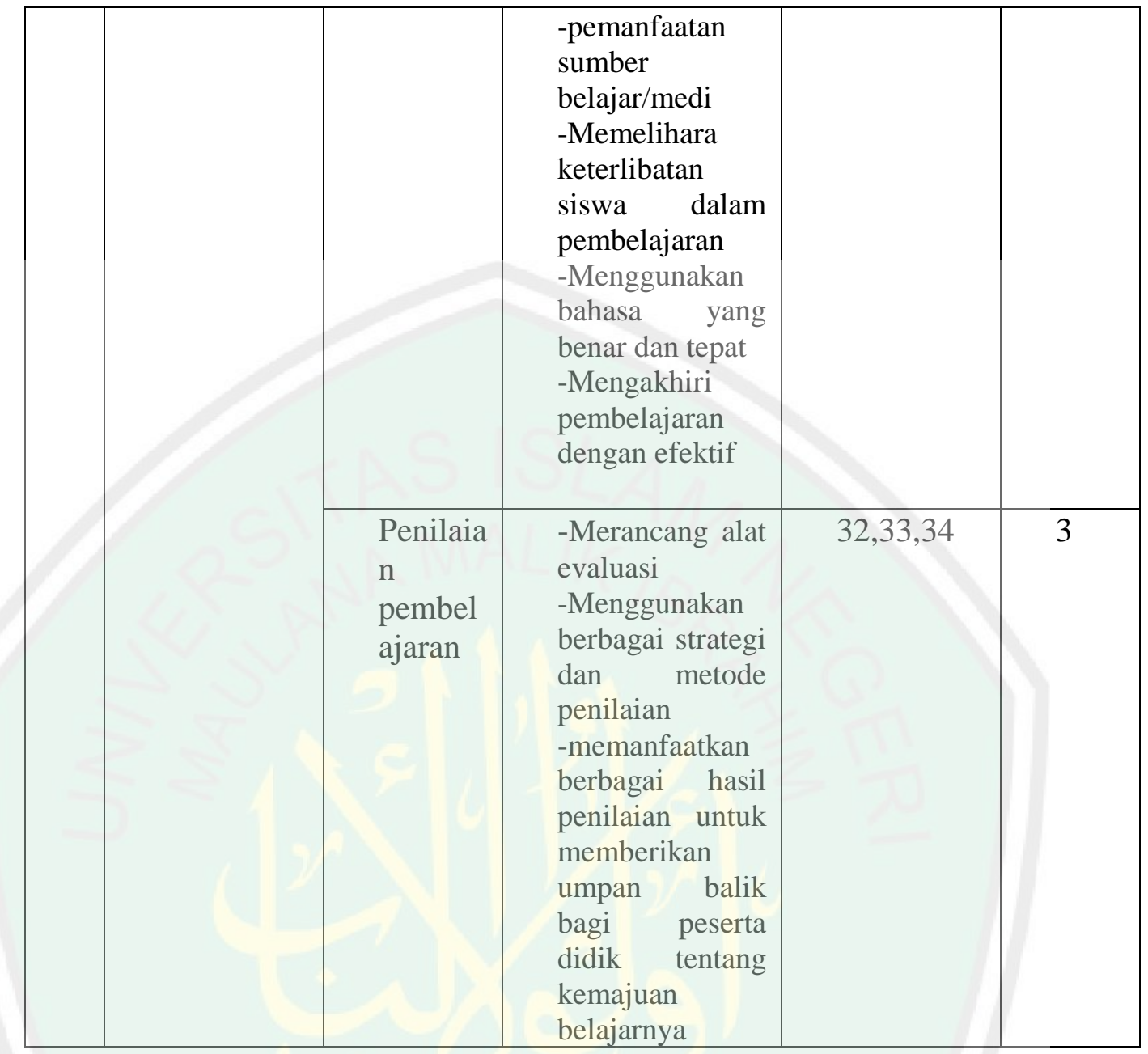

\section{Uji Validitas dan Reliabilitas}

Setelah variabel instrumen terkait dengan lingkungan kerja, motivasi kerja, kompensasi dan kinerja guru disusun maka instrumen tersebut terlebih dahulu diuji cobakan untuk mengetahui tingkat validitas dan reliabilitasnya.

\section{Validitas}

Instrumen yang telah disusun dalam penelitian ini disusun berdasarkan teori tentang variabel-variabel yang diteliti dalam penelitian ini. Oleh karenanya, sebuah instrumen harus memenuhi syarat validitas. Maka, sebelum digunakan untuk mengambil data penelitian maka instrumen tersebut harus diujicoba 
terlebih dahulu. Suatu instrumen dapat dikatakan valid apabila mampu mengungkap secara tepat data atau informasi dari suatu variabel yang akan diteliti dan mampu mengukur sebagaimana yang diinginkan. ${ }^{83}$

Dalam penelitian ini, uji coba dilakukan kepada guru selain sampel penelitian yang termasuk dalam populasi penelitian. Angket diuji cobakan kepada 30 responden guru Madrasah Aliyah. Jika hasil perhitungan terjadi thitung lebih besar dari tabel maka butir soal dinyatakan valid. Tetapi bila sebaliknya maka butir soal tersebut dinyatakan drop dan selanjutnya tidak digunakan dalam instrument penelitian.

Selanjutnya mengukur validitas instrument ini digunakan korelasi product moment correlation pada taraf signifikan dengan nilai probabilitas yang telah ditetapkan yaitu 0,05. Penggunaan perhitungan product moment karena skala data dalam penelitian ini termasuk interval dan pengukuran statistikanya adalah mean, deviasi standar, koefisien korelasi pearson (product moment).

Adapun rumus Product moment yang digunakan sebagai berikut:

$$
r_{x y}=\frac{N \sum X Y-\left(\sum X\right)\left(\sum Y\right)}{\sqrt{\left.\left\{N \sum x^{2}-\left(\sum x\right)^{2}\right\}\left\{N \sum Y^{2}-\sum Y\right)^{2}\right\}}}
$$

\section{Keterangan :}

$\mathrm{r}_{\mathrm{xy}}$ : Korelasi product moment

$\mathrm{N}$ : Jumlah responden atau sampel

$\mathrm{X}$ : Jumlah jawaban variabel $\mathrm{X}$

${ }^{83}$ Suharsimi Arikunto, Prosedur Penelitian; Suatu Pendekatan Praktek (Jakarta: Rineka Cipta, 2002), Hlm. 145. 
Y : Jumlah jawaban variabel Y

Uji validitas dalam penelitian ini menggunakan bantuan program SPSS(Statistical Product and Service Solutions) for Windows 23.0. Kriteria validitas adalah dengan membandingkan nilai signifikansi dengan nilai probabilitas sebagaimana yang telah ditetapkan yaitu 0,05 . Item dalam angket dinyatakan valid apabila nilai $\mathrm{r}_{\text {hitung }}$ yang merupakan nilai dari Corrected itemtotal Correation besar dari (>) $r_{\text {tabel. }}$

Berdasarkan hasil uji coba angket yang telah dilakukan peneliti terhadap 30 responden guru, maka diketahui bahwa kuesioner skala lingkungan kerja yang disebarkan oleh peneliti yang berjumlah total 6 item yang dinyatakan valid 6 item. Untuk lebih jelasnya mengenai hasil uji coba instrumen lingkungan kerja adalah sebagai berikut:

Tabel 3.3 : Ringkasan Hasil Uji Coba Validitas Variabel Lingkungan Kerja (X1)

\begin{tabular}{|c|c|c|c|c|}
\hline Item & rtabel & rhitung & Status & Keterangan \\
\hline Item 1 & \multirow{6}{*}{0,367} & 0,721 & Valid & $\mathrm{r}_{\text {hitung }}>\mathrm{r}_{\text {tabel }}$ \\
\hline Item 2 & & 0,472 & Valid & $r_{\text {hitung }}>r_{\text {tabel }}$ \\
\hline Item 3 & & 0,681 & Valid & $r_{\text {hitung }}>r_{\text {tabel }}$ \\
\hline Item 4 & & 0,384 & Valid & $r$ hitung $>r$ tabel \\
\hline Item 5 & & 0,688 & Valid & $r_{\text {hitung }}>r_{\text {tabel }}$ \\
\hline Item 6 & & 0,443 & Valid & $r$ hitung $>r$ tabel \\
\hline
\end{tabular}

Sedangkan hasil uji coba untuk variabel motivasi kerja yang telah dilakukan kepada 30 responden diperoleh data sebagai berikut:

Tabel 3.4: Ringkasan Hasil Uji Coba Validitas Variabel Motivasi Kerja $\left(\mathbf{X}_{2}\right)$

\begin{tabular}{|c|c|c|c|l|}
\hline Item & $\mathbf{r}_{\text {tabel }}$ & $\mathbf{r}_{\text {hitung }}$ & Status & \multicolumn{1}{|c|}{ Keterangan } \\
\cline { 1 - 3 } Item 1 & \multirow{2}{*}{0,367} & 0,712 & Valid & $\mathrm{r}_{\text {hitung }}>\mathrm{r}_{\text {tabel }}$ \\
\cline { 1 - 3 } Item 2 & 0,636 & Valid & $\mathrm{r}_{\text {hitung }}>\mathrm{r}_{\text {tabel }}$ \\
\hline Item 3 & & 0,732 & Valid & $\mathrm{r}_{\text {hitung }}>\mathrm{r}_{\text {tabel }}$ \\
\hline
\end{tabular}




\begin{tabular}{|c|c|c|c|c|}
\hline Item 4 & & 0,705 & Valid & $r_{\text {hitung }}>r_{\text {tabel }}$ \\
\hline Item 5 & \multirow{6}{*}{0,367} & 0,648 & Valid & $r_{\text {hitung }}>r_{\text {tabel }}$ \\
\hline Item 6 & & 0,533 & Valid & $r_{\text {hitung }}>r_{\text {tabel }}$ \\
\hline Item 7 & & 0,671 & Valid & $r_{\text {hitung }}>r_{\text {tabel }}$ \\
\hline Item 8 & & 0,533 & Valid & $r_{\text {hitung }}>r_{\text {tabel }}$ \\
\hline Item 9 & & 0,614 & Valid & $r_{\text {hitung }}>r_{\text {tabel }}$ \\
\hline Item 10 & & 0,463 & Valid & $r_{\text {hitung }}>r_{\text {tabel }}$ \\
\hline
\end{tabular}

Berdasarkan hasil uji coba angket di atas, maka diketahui bahwa kuesioner skala Motivasi kerja yang disebarkan oleh peneliti yang berjumlah total 10 item yang dinyatakan valid 10 item.

Sedangkan hasil uji coba kuesioner item kepuasan kerja yang disebarkan oleh peneliti yang berjumlah total 4 item, dinyatakan valid 4 item. Untuk lebih jelasnya mengenai hasil uji coba instrumen lingkungan kerja adalah sebagai berikut:

Tabel 3.5: Ringkasan Hasil Uji Coba Validitas Variabel Kepuasan Kerja (Z)

\begin{tabular}{|c|c|c|c|c|}
\hline Item & $\mathbf{r}_{\text {tabel }}$ & rhitung & Status & Keterangan \\
\hline Item 1 & \multirow{4}{*}{0,367} & 0,725 & Valid & $r_{\text {hitung }}>r_{\text {tabel }}$ \\
\hline Item 2 & & 0,850 & Valid & $\mathrm{r}_{\text {hitung }}>\mathrm{r}_{\text {tabel }}$ \\
\hline Item 3 & & 0,826 & Valid & $\mathrm{r}_{\text {hitung }}>\mathrm{r}_{\text {tabel }}$ \\
\hline Item 4 & & 0,546 & Valid & $\mathrm{r}_{\text {hitung }}>\mathrm{r}_{\text {tabel }}$ \\
\hline
\end{tabular}

Sedangkan hasil uji coba kuesioner item kinerja yang disebarkan oleh peneliti yang berjumlah total 14 item, dinyatakan valid 14 item. Untuk lebih jelasnya mengenai hasil uji coba instrumen lingkungan kerja adalah sebagai berikut:

Tabel 3.6: Ringkasan Hasil Uji Coba Validitas Variabel Kinerja (Y)

\begin{tabular}{|c|c|c|c|c|}
\hline Item & $\mathbf{r}_{\text {tabel }}$ & rhitung & Status & Keterangan \\
\hline Item 1 & & 0,644 & Valid & $\mathrm{r}_{\text {hitung }}>\mathrm{r}_{\text {tabel }}$ \\
\cline { 1 - 4 } Item 2 & 0,367 & 0,778 & Valid & $\mathrm{r}_{\text {hitung }}>\mathrm{r}_{\text {tabel }}$ \\
\cline { 3 - 5 }
\end{tabular}




\begin{tabular}{|c|c|c|c|c|}
\hline Item 3 & \multirow{12}{*}{0,367} & 0,597 & Valid & $\mathrm{r}_{\text {hitung }}>\mathrm{r}_{\text {tabel }}$ \\
\hline Item 4 & & 0,451 & Valid & $\mathrm{r}_{\text {hitung }}>\mathrm{r}_{\text {tabel }}$ \\
\hline Item 5 & & 0,727 & Valid & $\mathrm{r}_{\text {hitung }}>\mathrm{r}_{\text {tabel }}$ \\
\hline Item 6 & & 0,578 & Valid & $\mathrm{r}_{\text {hitung }}>\mathrm{r}_{\text {tabel }}$ \\
\hline Item 7 & & 0,904 & Valid & $\mathrm{r}_{\text {hitung }}>\mathrm{r}_{\text {tabel }}$ \\
\hline Item 8 & & 0,792 & Valid & $\mathrm{r}_{\text {hitung }}>\mathrm{r}_{\text {tabel }}$ \\
\hline Item 9 & & 0,823 & Valid & $\mathrm{r}_{\text {hitung }}>\mathrm{r}_{\text {tabel }}$ \\
\hline Item 10 & & 0,766 & Valid & $\mathrm{r}_{\text {hitung }}>\mathrm{r}_{\text {tabel }}$ \\
\hline Item 11 & & 0,731 & Valid & $\mathrm{r}_{\text {hitung }}>\mathrm{r}_{\text {tabel }}$ \\
\hline Item 12 & & 0,737 & Valid & $\mathrm{r}_{\text {hitung }}>\mathrm{r}_{\text {tabel }}$ \\
\hline Item 13 & & 0,735 & Valid & $\mathrm{r}_{\text {hitung }}>\mathrm{r}_{\text {tabel }}$ \\
\hline Item 14 & & 0,880 & Valid & $\mathrm{r}_{\text {hitung }}>\mathrm{r}_{\text {tabel }}$ \\
\hline
\end{tabular}

\section{Reliabilitas}

Reliabilitas pada suatu instrumen merujuk pada adanya kepercayaan pada instrumen untuk bisa digunakan sebagai alat pengumpul data karena instrumen sudah dinyatakan sudah baik. Sebagaimana yang diungkap oleh Arikunto bahwa instrumen yang dinyatakan baik dan reliabel dapat menghasilkan data yang dapat dipercaya juga. ${ }^{84}$

Koefisien reliabilitas digunakan untuk melihat konsistensi jawaban yang diberikan responden. Reliabilitas instrumen supervisi dengan skala kiraan frekuensi verbal menggunakan rumus Alpha Cronbach. Koefisien reliabilitas instrumen yang dihasilkan merupakan nilai tingkatan reliabilitas instrumen penelitian tersebut, atau disebut presentase tingkat keterhandalan instrumen. Adapun rumus perhitungan dengan menggunakan koefisien Alpha Cronbach adalah sebagai berikut:

$$
r=\left(\frac{k}{k-1}\right)\left(1-\frac{\sum \sigma_{b}^{2}}{\sigma_{t}^{2}}\right)
$$

\footnotetext{
${ }^{84}$ Suharsimi Arikunto, Prosedur Penelitian; Suatu Pendekatan Praktik, Hlm. 178.
} 


\section{Keterangan :}

\section{$r:$ Reliabilitas Instrumen}

\section{$\mathrm{k}$ : Jumlah item kuesioner}

$\sigma_{t}^{2}:$ Varian total

$\sum \sigma_{b}^{2}:$ Jumlah varian item

Pengujian reliabilitas angket yang dilakukan secara bersama-sama dengan validitas melalui SPSS versi 23.0 dengan metode Alpha Cronbachs. Berikut ini besaran alpha cronbachs yang diperoleh dari uji coba instrumen

\section{Tabel 3.6: Ringkasan Hasil Uji Coba Reliabilitas Instrumen}

\begin{tabular}{|l|l|c|}
\hline No. & \multicolumn{1}{|c|}{ Variabel } & Cronbach Alpha \\
\hline 1 & Lingkungan Kerja & 0,582 \\
\hline 2 & Motivasi kerja & 0,825 \\
\hline 3 & Kepuasan Kerja & 0,734 \\
\hline 4 & Kinerja Guru & 0,926 \\
\hline
\end{tabular}

Berdasarkan hasil uji coba instrumen di atas diperoleh nilai $r$ alpha yang dihasilkan bernilai positif dan lebih besar dari $\mathrm{r}$ tabel $(0,367)$ sehingga dapat dinyatakan bahwa instrumen variabel mempunyai tingkat keterhandalan dan bisa digunakan sebagai alat ukur.

\section{N. Analisis Data}

Analisis data merupakan langkah yang sangat penting dalam penelitian karena peranannya untuk menjawab hipotesis yang telah dirumuskan. Analisis 
data adalah proses pengorganisasian dan mengurutkan data dalam pola, kategori, dan satuan dasar agar dapat menjawab hipotesis yang sesuai dengan data. ${ }^{85}$

Untuk mengukur variabel yang digunakan dalam penelitian ini dilakukan kuesioner kepada responden. Kepada setiap jawaban diberi skor dengan tingkat pengukuran ordinal. Nilai yang digunakan adalah dari lima sampai satu, dengan catatan bahwa pernyataan bersifat positif, dan pemberian nilai dari satu sampai dengan lima apabila pernyataan-pernyataan yang terdapat di dalam kuesioner bersifat negatif.

Data-data yang diperoleh dari penelitian ini kemudian diolah dan dianalisa untuk menjawab rumusan masalah dan hipotesis penelitian yang telah di rancang. Diharapkan dengan dilakukannya analisis statistik dapat memberikan keputusan untuk menerima atau menolak suatu hipotesis. Langkah selanjutnya adalah menyajikan hasil analisis dalam bentuk angka yang kemudian dijelaskan dan dipresentasikan

Adapun data dalam penelitian ini dianalisis menggunakan metode analisis statistik sebagai berikut :

\section{Uji Asumsi Klasik}

Uji asumsi dilakukan untuk mengetahui apakah data yang telah diperoleh telah memenuhi syarat untuk dianalisis dengan menggunakan analisa korelasi dan regresi. Persyaratan awal untuk menggunakan regresi sebagai salah satu alat

\footnotetext{
${ }^{85}$ M. Iqbal Hasan, Metode Peneltian dan Aplikasinya (Jakarta: Ghalian Indonesia, 2002), hlm. 97
} 
analisis yaitu variabel penelitian harus diukur paling rendah dalam bentuk skala interval. ${ }^{86}$

Dalam analisis data dengan menggunakan teknik analisis regresi ganda (multiple Regression) adalah dengan melakukan uji asumsi terkait dengan linieritas dan normalitas. Apabila uji asumsi terpenuhi, maka analisis regresi yang telah dilakukan dapat tetap digunakan sebagai hasil akhir uji hipotesis penelitian. Adapun perincian uji linieritas, normalitas, multikolinieritas adalah sebagai berikut :

a. Uji Normalitas

Untuk mengetahui normal atau tidaknya data yang diperoleh, maka perlu dilakukan uji normalitas. Salah satu cara yang dipakai untuk mengetahui normalitas adalah dengan plot probabilitas normal, dengan menggunakan plot ini masing-masing nilai pengamatan dipasangkan dengan nilai harapan pada distribusi normal.

Apabila data-data atau titik-titik terkumpul disekitar garis lurus, maka normalitas data terpenuhi. Apabila data menyebar disekitar garis diagonal dan mengikutinya maka memenuhi asumsi normalitas. Sedangkan apabila menyebar jauh dari garis diagonal maka sebaliknya tidak memenuhi asumsi normalitas. Apabila uji normalitas yang dilakukan menggunakan One-sampel Kolmogrov-Smirnov maka dasar pengambilan keputusan adalah apabila nilai Asyimp. Sig. (2-tailed) $\geq$ dari

${ }^{86}$ R. Gunawan Sudarmanto, Analisis Regresi Linier Ganda dengan SPSS (Yogyakarta: Graha Ilmu, 2008), hlm. 101. 
nilai alpha (5\%), maka data berasal dari populasi yang mempunyai distribusi yang normal, sebaliknya apabila $\geq$ dari nilai alpha maka data berasal dari populasi yang tidak normal. ${ }^{87}$ Uji normalitas dalam penelitian menggunakan bantuan program SPSS (Statistical Product and Service Solution)23 for Windows.

\section{b. Uji Lineiritas}

Uji linieritas bertujuan untuk mengetahui linier atau tidaknya hubungan masing-masing variabel. Linieritas terpenuhi apabila grafik antara nilai prediksi dan nilai residual tidak membentuk pola tertentu yang dalam hal ini bisa berupa parabola, kubik atau yang lainnya.

Maksud dilakukannya uji linieritas, untuk mengetahui apakah hubungan antara variabel independen dengan variabel dependen bersifat linier (garis lurus).

\section{c. Uji Multikolinieritas}

Uji multikolinieritas dilakukan dengan tujuan untuk mengetahui ada tidaknya penyimpangan asumsi klasik, yaitu adanya hubungan linier antara variabel independen. Jika nilai VIF $<10$ maka tidak terjadi multikolinieritas, dan jika VIF > 10 maka terjadi multikolinieritas. ${ }^{88}$

\section{Uji Hipotesis}

Analisa dalam uji hipotesis didasarkan pada data yang diperoleh dari responden melalui angket yang telah disebarkan dalam penelitian ini. Pengujian

\footnotetext{
${ }^{87}$ R. Gunawan Sudarmanto, Analisis Regresi Linier Ganda dengan SPSS, hlm. 108.

${ }^{88}$ Fayruzah El-Faradis, Pengaruh Kompetensi Manajerial Kepala Sekolah dan Motivasi Kerja terhadap Kinerja Guru di Tarbiyatul Muallimin Al-Islamiyah (TMI) Putri Al-Amien Prenduan Sumenep Madura. (Malang: PPS Universitas Islam Negeri Malang 2016): Tesis tidak diterbitkan
} 
dalam penelitian ini menggunakan metode Structural Equation Model (SEM), dengan bantuan software PLS/ software spss 22.0.

Model Persamaan Struktural atau Structural Equation Model (SEM) adalah teknik-teknik statistika yang memungkinkan pengujian suatu rangkaian hubungan yang relatif kompleks secara simultan. Hubungan yang kompleks dapat dibangun antara satu atau beberapa variabel dependen dengan satu atau beberapa variabel independen. Mungkin juga terdapat suatu variabel yang berperan ganda yaitu sebagai variabel independen pada suatu hubungan, namun menjadi variabel dependen pada hubungan lain mengingat adanya hubungan kausalitas yang berjenjang. Masing-masing variabel dependen dan independen dapat berbentuk faktor atau konstruksi yang dibangun dari beberapa variabel indikator. Demikian pula diantara variabel-variabel itu dapat berbentuk sebuah variabel tunggal yang diobservasi atau yang diukur langsung dalam sebuah proses penelitian.

Model Persamaan Struktural semacam itu telah luas dikenal dalam penelitianpenelitian sosial melalui berbagai nama antara lain: causal modeling, causal analysis, simultaneous equation modeling atau analisis struktur kovarians. Seringkali SEM juga disebut sebagai Path Analysis . 


\section{BAB IV}

\section{HASIL PENELITIAN}

\section{A. Analisis Statistik Deskriptif}

Analisis statistik deskriptif dalam penelitian ini dijadikan bahan acuan dalam proses penguraian kecenderungan jawaban dari responden untuk setiap variabel, baik mengenai lingkungan kerja, motivasi kerja, kepuasan kerja, maupun kinerja guru Madrasah Aliyah di Pulau Bawean.

Penelitian ini mengambil sampel 125 orang guru dari lima madrasah aliyah yang ada di pulau Bawean, namun dikarenakan adanya beberapa guru yang tidak mengisi instrumen dan beberapa lagi tidak mengembalikan instrmen di karenakan hilang, maka jumlah sampel yang tersisa tinggal 100 orang guru.

\section{Lingkungan Kerja}

Instrumen yang digunakan untuk mengukur lingkungan kerja guru Madrasah Aliyah di Pulau Bawean berupa angket yang terdiri dari 6 item pertanyaan. Setiap item yang ada dalam angket diberi skor dengan skala 1-5, maka bisa ditarik kesimpulan bahwa skor tertinggi adalah 5 dan skor terendah adalah 1.

Cara untuk melihat skor harapan tertinggi adalah dengan cara mengalikan skor tertinggi dengan jumlah item pertanyaan, sehingga untuk variabel lingkungan kerja skor tertinggi adalah 5 x $6=30$. Sedangkan untuk skor harapan terendah dengan cara mengalikan skor terendah dengan jumlah item, dan skor terendah dalam instrumen yaitu 1. Jadi skor terendah untuk 
variabel lingkungan kerja adalah 1 x $6=6$. Berdasarkan hasil perhitungan di atas dapat kita tentukan interval antar kelas yang menggambarkan lingkungan kerja, yaitu: sangat setuju, setuju, kurang setuju, tidak setuju dan sangat tidak setuju.

Cara untuk menghitung panjang kelas interval adalah skor tertinggi dikurangi skor terendah ditambah 1 dan hasilnya dibagi 5. Jadi interval antar kelas untuk variabel lingkungan kerja guru adalah sebagai berikut: ((30 - 6) $+1): 5=5$.

Tabel 4.1

Deskripsi Tanggapan Responden Terhadap Variabel Lingkungan Kerja Guru Madrasah Aliyah di Pulau Bawean

\begin{tabular}{|l|l|c|c|c|}
\hline No. & \multicolumn{1}{|c|}{ Klasifikasi } & $\begin{array}{c}\text { Rentang } \\
\text { Skor }\end{array}$ & Frekuensi & Persentase \\
\hline 1 & Sangat baik & $26-30$ & 64 & $64 \%$ \\
\hline 2 & Baik & $21-25$ & 34 & $34 \%$ \\
\hline 3 & Sedang & $16-20$ & 2 & $2 \%$ \\
\hline 4 & Buruk & $11-15$ & 0 & $0 \%$ \\
\hline 5 & Sangat buruk & $6-10$ & 0 & $0 \%$ \\
\hline \multicolumn{2}{|c|}{ Jumlah } & 100 & $100 \%$ \\
\hline
\end{tabular}

Berdasarkan tabel di atas, dapat dijelaskan bahwa 64 responden (64\%) mengatakan bahwa lingkungan kerja guru Madrasah Aliyah di Pulau Bawean kategori sangat baik, sedangkan 34 responden (34\%) menyatakan lingkungan kerja guru Madrasah Aliyah di Pulau Bawean dalam kategori baik, dan 2 responden (2\%) menyatakan dalam kategori sedang.

Distribusi di atas dapat digambarkan dalam bentuk diagram sebagai berikut: 
Gambar 4.1: Diagram Lingkungan Kerja

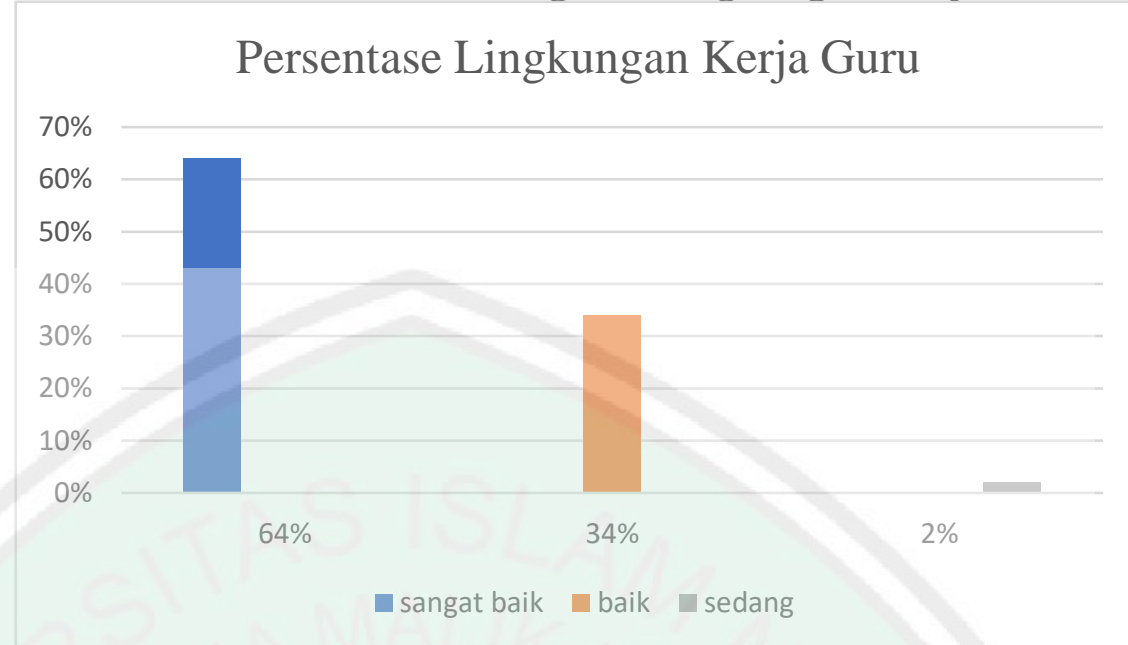

Sedangkan persentase tabulasi jawaban dari variabel lingkungan kerja guru dapat dilihat pada tabel berikut ini:

Tabel 4.2:

Tabulasi Hasil Jawaban Kuesioner Lingkungan Kerja

\begin{tabular}{|c|c|c|c|c|r|r|r|r|r|r|}
\hline Indikator & \multicolumn{2}{|c|}{ Skor 5 } & \multicolumn{2}{c|}{ Skor 4 } & \multicolumn{2}{c|}{ Skor 3 } & \multicolumn{2}{|c|}{ Skor 2 } & \multicolumn{2}{|c|}{ Skor 1 } \\
\hline & F & \% & F & \% & F & \% & F & \% & F & \% \\
\hline Q1 & 57 & $57 \%$ & 41 & $41 \%$ & 2 & $2 \%$ & 0 & $0 \%$ & 0 & $0 \%$ \\
\hline Q2 & 63 & $63 \%$ & 29 & $29 \%$ & 8 & $8 \%$ & 0 & $0 \%$ & 0 & $0 \%$ \\
\hline Q3 & 43 & $43 \%$ & 46 & $46 \%$ & 2 & $2 \%$ & 0 & $0 \%$ & 9 & $9 \%$ \\
\hline Q4 & 45 & $45 \%$ & 18 & $18 \%$ & 18 & $18 \%$ & 0 & $0 \%$ & 0 & $0 \%$ \\
\hline Q5 & 68 & $68 \%$ & 32 & $32 \%$ & 0 & $0 \%$ & 0 & $0 \%$ & 0 & $0 \%$ \\
\hline Q6 & 70 & $70 \%$ & 27 & $27 \%$ & 3 & $3 \%$ & 0 & $0 \%$ & 0 & $0 \%$ \\
\hline
\end{tabular}

Berdasarkan tabel di atas, maka dapat dijelaskan tanggapan responden terhadap kuesioner variabel lingkungan kerja guru Madrasah Aliyah di pulau Bawean sebagai berikut:

a) Pertanyaan nomor 1, tanggapan dari 100 guru, sebanyak 57 guru (57\%) mengatakan sangat setuju bahwa ruangan tempat mereka bekerja dan beraktivitas kebersihan dan kerapiannya terjaga, sebanyak $41(41 \%)$ guru mengatakan setuju dan $2(2 \%)$ guru mengatakan kurang setuju. 
b) Pertanyaan nomor 2, tanggapan dari 100 guru, sebanyak 63 guru (63\%) mengatakan sangat setuju bahwa lingkungan mereka bekerja baik dan nyaman, sebanyak 29 (29\%) guru mengatakan setuju dan $8(8 \%)$ guru mengatakan kurang setuju.

c) Pertanyaan nomor 3, jawaban dari 100 guru, 43 guru (43\%) menyatakan sangat setuju bahwa tenaga keamanan terjadwal dan bekerja dengan baik, sebanyak 29 (29\%) guru mengatakan setuju dan $2(2 \%)$ guru mengatakan kurang setuju, dan 9 guru mengatakan sangat tidak setuju.

d) Pertanyaan nomor 4, jawaban dari 100 guru menyatakan bahwa pimpinan sering memberi pengarahan dan perhatian pada bawahan, dengan kriteria sangat setuju sebanyak 45 guru (45\%), setuju sebanyak 18 guru (18\%), kurang setuju sebanyak 18 guru (18\%),

e) Pertanyaan nomor 5, jawaban dari 100 guru menyatakan bahwa terjalin komunikasi yang baik antar sesama guru dan mendapat dukungan dari teman ketika dapat masalah, dimulai dengan kriteria sangat setuju sebanyak 68 guru (68\%), dan setuju sebanyak guru 32 $(32 \%)$.

f) Pertanyaan nomor 6, jawaban dari 100 guru menyatakan bahwa komunikasi antar guru dengan karyawan yang terjalin dengan baik, dimulai dengan kriteria sangat setuju sebanyak 70 guru (70\%), setuju sebanyak 27 guru (27\%), dan kurang setuju sebanyak 3 guru (3\%). 


\section{Motivasi Kerja Guru}

Instrumen yang digunakan untuk mengukur variabel motivasi kerja guru Madrasah Aliyah di Pulau Bawean berupa angket yang terdiri dari 10 item pertanyaan. Setiap item yang ada dalam angket diberi skor dengan skala 1-5, maka bisa ditarik kesimpulan bahwa skor tertinggi adalah 5 dan skor terendah adalah 1.

Cara untuk melihat skor harapan tertinggi adalah dengan cara mengalikan skor tertinggi dengan jumlah item pertanyaan, sehingga untuk variabel lingkungan kerja skor tertinggi adalah 5 x $10=50$. Sedangkan untuk skor harapan terendah dengan cara mengalikan skor terendah dengan jumlah item, dan skor terendah dalam instrumen yaitu 1. Jadi skor terendah untuk variabel lingkungan kerja adalah 1 x $10=10$. Berdasarkan hasil perhitungan di atas dapat kita tentukan interval antar kelas yang menggambarkan lingkungan kerja, yaitu: sangat setuju, setuju, kurang setuju, tidak setuju dan sangat tidak setuju.

Cara untuk menghitung panjang kelas interval adalah skor tertinggi dikurangi skor terendah ditambah 1 dan hasilnya dibagi 5. Jadi interval antar kelas untuk variabel lingkungan kerja guru adalah sebagai berikut: ((50 - 10) $+1): 5=8,2$ (dibulatkan menjadi 8).

Tabel 4.3: Deskripsi Motivasi Kerja

\begin{tabular}{|l|c|c|c|c|}
\hline No. & Klasifikasi & Interval & Frekuensi & Persentase \\
\hline
\end{tabular}




\begin{tabular}{|c|l|c|c|c|}
\hline 1 & Sangat tinggi & $42-50$ & 76 & $76 \%$ \\
\hline 2 & Tinggi & $34-41$ & 24 & $24 \%$ \\
\hline 3 & Sedang & $26-33$ & 0 & $0 \%$ \\
\hline 4 & Rendah & $18-25$ & 0 & $0 \%$ \\
\hline 5 & Sangat rendah & $10-17$ & 0 & $0 \%$ \\
\hline \multicolumn{3}{|c|}{ Jumlah } & 100 & $100 \%$ \\
\hline
\end{tabular}

Berdasarkan tabel di atas dapat dijelaskan bahwa sebanyak 76 responden (76\%) berada dalam kategori mempunyai motivasi kerja yang sangat tinggi, dan sisanya 24 responden (24\%) berada dalam kategori tinggi. Melalui hasil perhitungan di atas bisa diambil kesimpulan bahwa motivasi kerja guru Madrasah Aliyah di Pulau Bawean dalam kondisi yang baik, hal ini bisa dilihat dari kecenderungan responden berada di kategori sangat tinggi.

Distribusi di atas dapat digambarkan dalam bentuk diagram sebagai berikut

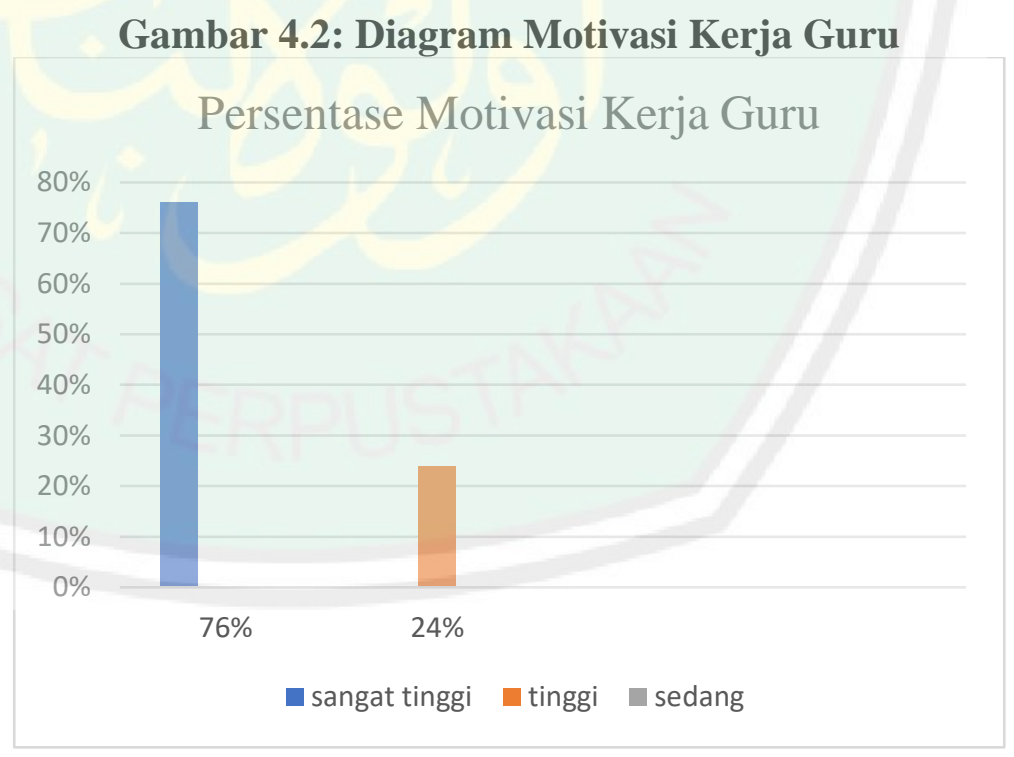

Sedangkan persentase tabulasi jawaban dari variabel lingkungan kerja guru dapat dilihat pada tabel berikut ini: 
Tabel 4.4:

Tabulasi Hasil Jawaban Kuesioner Motivasi Kerja Guru

\begin{tabular}{|c|c|c|c|c|c|c|c|c|c|c|}
\hline Indikator & \multicolumn{2}{|c|}{ Skor 1} & \multicolumn{2}{|c|}{ Skor 2} & \multicolumn{2}{|c|}{ Skor 3} & \multicolumn{2}{|c|}{ Skor 4} & \multicolumn{2}{|c|}{ Skor 5} \\
\hline & $\mathbf{F}$ & $\%$ & $\mathbf{F}$ & $\%$ & $\mathbf{F}$ & $\%$ & $\mathbf{F}$ & $\%$ & $\mathbf{F}$ & $\%$ \\
\hline Q1 & 0 & $0 \%$ & 0 & $0 \%$ & 0 & $0 \%$ & 40 & $40 \%$ & 60 & $60 \%$ \\
\hline Q2 & & $1 \%$ & 2 & $2 \%$ & 8 & $8 \%$ & 46 & $46 \%$ & 43 & $43 \%$ \\
\hline Q3 & 0 & $0 \%$ & 0 & $0 \%$ & 7 & $7 \%$ & 54 & $54 \%$ & 39 & $39 \%$ \\
\hline Q4 & 0 & $0 \%$ & 0 & $0 \%$ & 2 & $2 \%$ & 45 & $45 \%$ & 53 & $53 \%$ \\
\hline Q5 & 0 & $0 \%$ & 0 & $0 \%$ & 14 & $14 \%$ & 47 & $47 \%$ & 39 & $39 \%$ \\
\hline Q6 & 0 & $0 \%$ & 0 & $0 \%$ & 0 & $0 \%$ & 31 & $31 \%$ & 69 & $69 \%$ \\
\hline Q7 & 0 & $0 \%$ & 0 & $0 \%$ & 9 & $9 \%$ & 53 & $53 \%$ & 38 & $38 \%$ \\
\hline Q8 & 0 & $0 \%$ & 2 & $2 \%$ & 1 & $1 \%$ & 29 & $29 \%$ & 68 & $68 \%$ \\
\hline Q9 & 0 & $0 \%$ & 0 & $0 \%$ & 0 & $0 \%$ & 20 & $20 \%$ & 80 & $80 \%$ \\
\hline Q10 & 0 & $0 \%$ & 0 & $0 \%$ & 0 & $0 \%$ & 35 & $35 \%$ & 65 & $65 \%$ \\
\hline
\end{tabular}

Berdasarkan tabel di atas, maka dapat dijelaskan tanggapan responden terhadap kuesioner variabel lingkungan kerja guru Madrasah Aliyah di pulau Bawean sebagai berikut:

a) Pertanyaan nomor 1, tanggapan dari 100 guru, sebanyak 60 guru (60\%) mengatakan sangat setuju bahwa mereka mengatur dan mengerjakan tugas dengan baik, sebanyak 40 (40\%) guru mengatakan setuju.

b) Pertanyaan nomor 2, tanggapan dari 100 guru, sebanyak 43 guru (43\%) mengatakan sangat setuju bahwa mereka memiliki sosok figur yang jadi panutan, sebanyak 46 guru (46\%) mengatakan setuju dan 8 guru (8\%) mengatakan kurang setuju, 2 guru (2\%) mengatakan tidak setuju dan 1 guru (1\%) mengatakan sangat tidak setuju.

c) Pertanyaan nomor 3, tanggapan dari 100 guru, sebanyak 39 guru (39\%) mengatakan sangat setuju bahwa mereka menjaga citra mereka di tempat kerja dengan mengerjakan tugas dengan baik, 
sebanyak 54 guru (54\%) mengatakan setuju, dan 7 orang (7\%) mengatakan kurang setuju.

d) Pertanyaan nomor 4, tanggapan dari 100 guru, sebanyak 53 guru (53\%) mengatakan sangat setuju bahwa mereka berpikir realistis dalam mengerjakan tugas dengan baik, sebanyak 45 guru (45\%) mengatakan setuju, dan 2 orang (2\%) mengatakan kurang setuju.

e) Pertanyaan nomor 5, tanggapan dari 100 guru, sebanyak 39 guru (39\%) mengatakan sangat setuju bahwa mereka mempunyai pengaruh dalam mengerjakan tugas, sebanyak 47 guru (47\%) mengatakan setuju, dan 14 orang (14\%) mengatakan kurang setuju.

f) Pertanyaan nomor 6, tanggapan dari 100 guru, sebanyak 69 guru $(69 \%)$ mengatakan sangat setuju bahwa mereka bekerja sama dalam mengerjakan tugas dengan baik, sebanyak 31 guru (31\%) mengatakan setuju.

g) Pertanyaan nomor 7, tanggapan dari 100 guru, sebanyak 38 guru (38\%) mengatakan sangat setuju bahwa mereka memberikan saran dan diikuti oleh rekan kerja, sebanyak 53 guru (53\%) mengatakan setuju, dan 9 orang (9\%) mengatakan kurang setuju.

h) Pertanyaan nomor 8, tanggapan dari 100 guru, sebanyak 68 guru (68\%) mengatakan sangat setuju bahwa mereka menjaga hubungan image sebagai guru, sebanyak 45 guru (45\%) mengatakan setuju, dan 2 orang (2\%) mengatakan kurang setuju. 
i) Pertanyaan nomor 9, tanggapan dari 100 guru, sebanyak 80 guru (80\%) mengatakan sangat setuju bahwa mereka menjaga hubungan pertemanan dengan rekan kerja, sebanyak 20 guru (45\%) mengatakan setuju.

j) Pertanyaan nomor 10, tanggapan dari 100 guru, sebanyak 64 guru (64\%) mengatakan sangat setuju bahwa mereka bekerja sama dalam melaksanakan tugas yang sulit, sebanyak 35 guru (35\%) mengatakan setuju, dan 1 orang (1\%) mengatakan kurang setuju.

\section{Kepuasan Kerja Guru}

Instrumen yang digunakan untuk mengukur kepuasan kerja guru Madrasah Aliyah di Pulau Bawean berupa angket yang terdiri dari 4 item pertanyaan. Setiap item yang ada dalam angket diberi skor dengan skala 1-5, maka bisa ditarik kesimpulan bahwa skor tertinggi adalah 5 dan skor terendah adalah 1.

Cara untuk melihat skor harapan tertinggi adalah dengan cara mengalikan skor tertinggi dengan jumlah item pertanyaan, sehingga untuk variabel kepuasan kerja guru skor tertinggi adalah 5 x $4=20$. Sedangkan untuk skor harapan terendah dengan cara mengalikan skor terendah dengan jumlah item, dan skor terendah dalam instrumen yaitu 1. Jadi skor terendah untuk variabel lingkungan kerja adalah 1 x $4=4$. Berdasarkan hasil perhitungan di atas dapat kita tentukan interval antar kelas yang menggambarkan kepuasan kerja guru, yaitu: sangat tinggi, tinggi, sedang, rendah dan sangat rendah. 
Cara untuk menghitung panjang kelas interval adalah skor tertinggi dikurangi skor terendah ditambah 1 dan hasilnya dibagi 5. Jadi interval antar kelas untuk variabel lingkungan kerja guru adalah sebagai berikut: ((20 - 4) $+1): 5=3,2($ dibulatkan jadi 3).

Tabel 4.5: Deskripsi Kepuasan Kerja Guru

\begin{tabular}{|c|l|c|c|c|}
\hline No. & \multicolumn{1}{|c|}{ Klasifikasi } & Interval & Frekuensi & Persentase \\
\hline 1 & Sangat tinggi & $17-20$ & 66 & $66 \%$ \\
\hline 2 & Tinggi & $14-16$ & 34 & $34 \%$ \\
\hline 3 & sedang & $11-13$ & 0 & $0 \%$ \\
\hline 4 & Rendah & $7-10$ & 0 & $0 \%$ \\
\hline 5 & Sangat rendah & $4-6$ & 0 & $0 \%$ \\
\hline \multicolumn{3}{|c|}{ Jumlah } & 100 & $100 \%$ \\
\hline
\end{tabular}

Berdasarkan tabel 4.5 dapat dijelaskan bahwa sebanyak 66 responden $(66 \%)$ berada dalam kategori mempunyai kepuasan kerja yang sangat tinggi, dan sisanya 34 responden (34\%) berada dalam kategori tinggi. Melalui hasil perhitungan di atas bisa diambil kesimpulan bahwa kepuasan kerja guru Madrasah Aliyah di Pulau Bawean dalam kondisi yang baik, hal ini bisa dilihat dari kecenderungan responden berada di kategori sangat tinggi.

Distribusi di atas dapat digambarkan dalam bentuk diagram sebagai berikut:

\section{Gambar 4.3: Diagram Kepuasan Kerja Guru}

Persentase kepuasan kerja guru

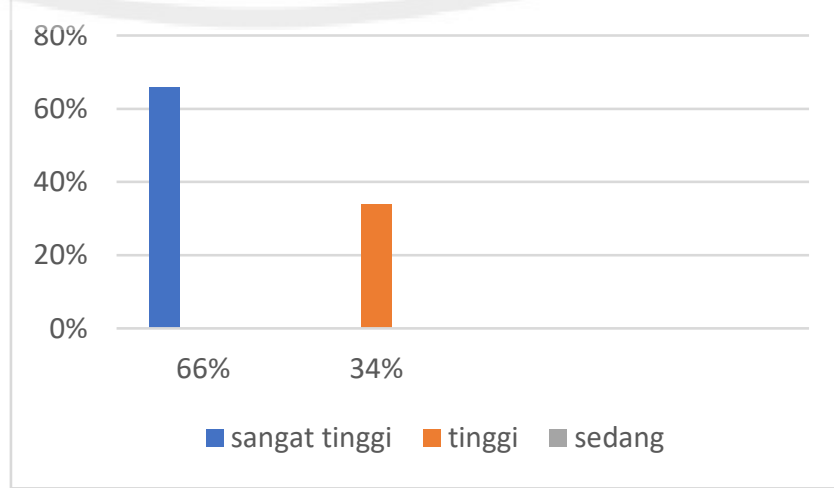


Sedangkan persentase tabulasi jawaban dari variabel kepuasan kerja guru dapat dilihat pada tabel berikut ini:

Tabel 4.6:

Tabulasi Hasil Jawaban Kuesioner Kepuasan Kerja Guru

\begin{tabular}{|c|r|r|r|r|r|r|r|r|r|r|}
\hline Indikator & \multicolumn{2}{|c|}{ Skor 1 } & \multicolumn{2}{c|}{ Skor 2 } & \multicolumn{2}{c|}{ Skor 3 } & \multicolumn{2}{c|}{ Skor 4 } & \multicolumn{2}{c|}{ Skor 5 } \\
\hline & F & \% & F & \multicolumn{1}{c|}{$\%$} & F & \% & F & \% & F & \% \\
\hline Q1 & 0 & $0 \%$ & 0 & $0 \%$ & 0 & $0 \%$ & 36 & $36 \%$ & 64 & $64 \%$ \\
\hline Q2 & 0 & $0 \%$ & 0 & $0 \%$ & 2 & $2 \%$ & 43 & $43 \%$ & 55 & $55 \%$ \\
\hline Q3 & 3 & $3 \%$ & 1 & $1 \%$ & 25 & $25 \%$ & 42 & $42 \%$ & 29 & $29 \%$ \\
\hline Q4 & 0 & $0 \%$ & 3 & $3 \%$ & 16 & $16 \%$ & 37 & $37 \%$ & 44 & $44 \%$ \\
\hline
\end{tabular}

Berdasarkan tabel di atas, maka dapat dijelaskan tanggapan responden terhadap kuesioner variabel Kepuasan kerja guru Madrasah Aliyah di Pulau Bawean sebagai berikut:

a) Pertanyaan nomor 1, tanggapan dari 100 guru, sebanyak 64 guru (64\%) mengatakan sangat setuju bahwa Upah yang mereka terima wajar dan proporsional, sebanyak 36 (36\%) guru mengatakan setuju.

b) Pertanyaan nomor 2, tanggapan dari 100 guru, sebanyak 55 guru $(55 \%)$ mengatakan sangat setuju bahwa pekerjaan mereka menarik dan menyenangkan, sebanyak 43 (43\%) guru mengatakan setuju dan $2(2 \%)$ guru mengatakan kurang setuju.

c) Pertanyaan nomor 3, jawaban dari 100 guru, 29 guru (29\%) menyatakan sangat setuju bahwa ada kesempatan promosi bila bekerja dengan baik, sebanyak 42 guru (42\%) mengatakan setuju dan $25(25 \%)$ guru mengatakan kurang setuju, dan 1 guru (1\%) mengatakan tidak setuju. 
d) Pertanyaan nomor 3, jawaban dari 100 guru, 44 guru (44\%) menyatakan sangat setuju bahwa rekan kerja dan atasan bersifat bersahabat dan mendorong, sebanyak 37 guru (37\%) mengatakan setuju dan $16(16 \%)$ guru mengatakan kurang setuju, dan 3 guru $(3 \%)$ mengatakan tidak setuju.

\section{4. kinerja guru}

Instrumen yang digunakan untuk mengukur kinerja guru Madrasah Aliyah di Pulau Bawean berupa angket yang terdiri dari 14 item pertanyaan. Setiap item yang ada dalam angket diberi skor dengan skala 1-5, maka bisa ditarik kesimpulan bahwa skor tertinggi adalah 5 dan skor terendah adalah 1 .

Cara untuk melihat skor harapan tertinggi adalah dengan cara mengalikan skor tertinggi dengan jumlah item pertanyaan, sehingga untuk variabel kepuasan kerja guru skor tertinggi adalah 5 x $14=70$. Sedangkan untuk skor harapan terendah dengan cara mengalikan skor terendah dengan jumlah item, dan skor terendah dalam instrumen yaitu 1. Jadi skor terendah untuk variabel lingkungan kerja adalah 1 x $14=14$. Berdasarkan hasil perhitungan di atas dapat kita tentukan interval antar kelas yang menggambarkan kinerja guru, yaitu: sangat tinggi, tinggi, sedang, rendah dan sangat rendah.

Cara untuk menghitung panjang kelas interval adalah skor tertinggi dikurangi skor terendah ditambah 1 dan hasilnya dibagi 5. Jadi interval antar kelas untuk variabel lingkungan kerja guru adalah sebagai berikut: ((70 - 14) $+1): 5=11,4($ dibulatkan jadi 4$)$. 
Tabel 4.7: Deskripsi Kinerja Guru

\begin{tabular}{|c|l|l|r|r|}
\hline No. & \multicolumn{1}{|c|}{ Klasifikasi } & Interval & Frekuensi & Persentase \\
\hline 1 & Sangat tinggi & $58-70$ & 58 & $58 \%$ \\
\hline 2 & Tinggi & $47-57$ & 38 & $38 \%$ \\
\hline 3 & sedang & $36-46$ & 4 & $4 \%$ \\
\hline 4 & Rendah & $25-35$ & 0 & $0 \%$ \\
\hline 5 & Sangat rendah & $14-24$ & 0 & $0 \%$ \\
\hline \multicolumn{3}{|c|}{ Jumlah } & 100 & $100 \%$ \\
\hline
\end{tabular}

Berdasarkan tabel 4.5 dapat dijelaskan bahwa sebanyak 58 responden (58\%) berada dalam kategori mempunyai ke kinerja yang sangat tinggi, dan sisanya 38 responden (38\%) berada dalam kategori tinggi dan 4 responden (4\%)dalam kategori sedang. Melalui hasil perhitungan di atas bisa diambil kesimpulan bahwa kinerja guru Madrasah Aliyah di Pulau Bawean dalam kondisi yang baik, hal ini bisa dilihat dari kecenderungan responden berada di kategori sangat tinggi.

Distribusi di atas dapat digambarkan dalam bentuk diagram sebagai berikut:

Gambar 4.4: Diagram Kinerja Guru Persentase Kinerja Guru

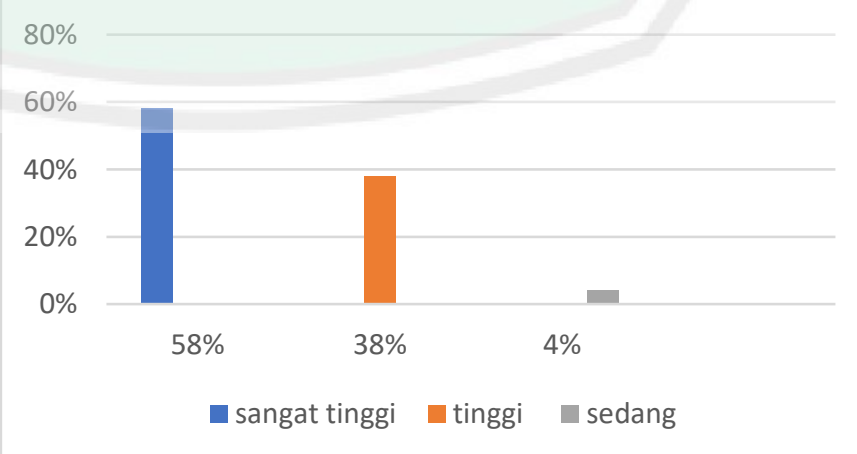


Sedangkan persentase tabulasi jawaban dari variabel kinerja guru dapat dilihat pada tabel berikut ini:

Tabel 4.8:

Tabulasi Hasil Jawaban Kuesioner Kinerja Guru

\begin{tabular}{|c|r|r|r|r|r|r|r|r|r|r|}
\hline Indikator & \multicolumn{2}{|c|}{ Skor 1 } & \multicolumn{2}{c|}{ Skor 2 } & \multicolumn{2}{c|}{ Skor 3 } & \multicolumn{2}{c|}{ Skor 4 } & \multicolumn{2}{c|}{ Skor 5 } \\
\hline & F & \% & F & \% & F & \% & F & \% & F & \% \\
\hline Q1 & 2 & $2 \%$ & 1 & $1 \%$ & 20 & $20 \%$ & 47 & $47 \%$ & 30 & $30 \%$ \\
\hline Q2 & 0 & $0 \%$ & 0 & $0 \%$ & 19 & $19 \%$ & 47 & $47 \%$ & 34 & $34 \%$ \\
\hline Q3 & 0 & $0 \%$ & 0 & $0 \%$ & 12 & $12 \%$ & 45 & $45 \%$ & 43 & $43 \%$ \\
\hline Q4 & 0 & $0 \%$ & 0 & $0 \%$ & 10 & $10 \%$ & 44 & $44 \%$ & 46 & $46 \%$ \\
\hline Q5 & 0 & $0 \%$ & 0 & $0 \%$ & 15 & $15 \%$ & 43 & $43 \%$ & 42 & $42 \%$ \\
\hline Q6 & 0 & $0 \%$ & 0 & $0 \%$ & 3 & $3 \%$ & 45 & $45 \%$ & 52 & $52 \%$ \\
\hline Q7 & 0 & $0 \%$ & 0 & $0 \%$ & 11 & $11 \%$ & 54 & $54 \%$ & 35 & $35 \%$ \\
\hline Q8 & 0 & $0 \%$ & 0 & $0 \%$ & 10 & $10 \%$ & 61 & $61 \%$ & 29 & $29 \%$ \\
\hline Q9 & 0 & $0 \%$ & 0 & $0 \%$ & 0 & $0 \%$ & 62 & $62 \%$ & 38 & $38 \%$ \\
\hline Q10 & 0 & $0 \%$ & 0 & $0 \%$ & 0 & $0 \%$ & 39 & $39 \%$ & 61 & $61 \%$ \\
\hline Q11 & 0 & $0 \%$ & 2 & $2 \%$ & 8 & $8 \%$ & 52 & $52 \%$ & 38 & $38 \%$ \\
\hline Q12 & 0 & $0 \%$ & 0 & $0 \%$ & 4 & $4 \%$ & 66 & $66 \%$ & 30 & $30 \%$ \\
\hline Q11 & 0 & $0 \%$ & 0 & $0 \%$ & 9 & $9 \%$ & 57 & $57 \%$ & 34 & $34 \%$ \\
\hline Q12 & 0 & $0 \%$ & 0 & $0 \%$ & 4 & $4 \%$ & 68 & $68 \%$ & 28 & $28 \%$ \\
\hline
\end{tabular}

Berdasarkan tabel di atas, maka dapat dijelaskan tanggapan responden terhadap kuesioner variabel kinerja guru Madrasah Aliyah di Pulau Bawean sebagai berikut:

a) Pertanyaan nomor 1, tanggapan dari 100 guru, sebanyak 30 guru (30\%) mengatakan sangat setuju bahwa mereka membuat RPP sesuai karakter siswa, sebanyak 47 guru (47\%) mengatakan setuju, 20 responden $(20 \%)$ mengatakan kurang setuju, 1 orang responden (1\%) mengatakan tidak setuju dan 2 responden (2\%) mengatakan sangat tidak setuju.

b) Pertanyaan nomor 2, tanggapan dari 100 guru, sebanyak 34 guru (34\%) mengatakan sangat setuju bahwa mereka menyusun RPP 
secara runut, logis dan kontekstual, sebanyak 47 guru $(47 \%)$ mengatakan setuju dan 19 guru (19\%) mengatakan kurang setuju.

c) Pertanyaan nomor 3, tanggapan dari 100 guru, sebanyak 43 guru (43\%) mengatakan sangat setuju bahwa mereka menyusun kegiatan pembelajaran sesuai kebutuhan siswa, sebanyak 45 guru (45\%) mengatakan setuju dan 12 guru (12\%) mengatakan kurang setuju

d) Pertanyaan nomor 4, jawaban dari 100 guru, 46 guru (46\%) menyatakan sangat setuju bahwa mereka membuat media pembelajaran sesuai dengan materi dan sumber pelajaran, sebanyak 44 guru (44\%) mengatakan setuju dan 10 (10\%) guru mengatakan kurang setuju.

e) Pertanyaan nomor 5, tanggapan dari 100 guru, sebanyak 42 guru (42\%) mengatakan sangat setuju bahwa mereka memulai pembelajaran dengan efektif, sebanyak 43 guru (43\%) mengatakan setuju, 15 responden (15\%) mengatakan kurang setuju.

f) Pertanyaan nomor 6, tanggapan dari 100 guru, sebanyak 52 guru (52\%) mengatakan sangat setuju bahwa mereka menguasai materi yang diajarkan, sebanyak 45 guru (45\%) mengatakan setuju dan 3 guru (3\%) mengatakan kurang setuju.

g) Pertanyaan nomor 7, tanggapan dari 100 guru, sebanyak 35 guru (35\%) mengatakan sangat setuju bahwa mereka menggunakan strategi pembelajaran yang menarik, sebanyak 54 guru (54\%) mengatakan setuju dan 11 guru (11\%) mengatakan kurang setuju 
h) Pertanyaan nomor 8, jawaban dari 100 guru, 29 guru (29\%) menyatakan sangat setuju bahwa mereka memanfaatkan media dalam pembelajaran, sebanyak 61 guru (61\%) mengatakan setuju dan $10(10 \%)$ guru mengatakan kurang setuju.

i) Pertanyaan nomor 9, tanggapan dari 100 guru, sebanyak 38 guru (38\%) mengatakan sangat setuju bahwa mereka mendukung dan menerima inisiatif dari siswa, dan sebanyak 62 guru (62\%) mengatakan setuju.

j) Pertanyaan nomor 10, tanggapan dari 100 guru, sebanyak 61 guru (61\%) mengatakan sangat setuju bahwa menggunakan bahasa yang mudah dipahami siswa dalam mengajar, dan sebanyak 39 guru (47\%) mengatakan setuju .

k) Pertanyaan nomor 11, tanggapan dari 100 guru, sebanyak 38 guru (43\%) mengatakan sangat setuju bahwa mereka mengaitkan materi dengan materi berikutnya, sebanyak 52 guru (52\%) mengatakan setuju dan 8 guru (8\%) mengatakan kurang setuju

1) Pertanyaan nomor 12, jawaban dari 100 guru, 30 guru (30\%) menyatakan sangat setuju bahwa mereka merancang alat evaluasi, sebanyak 66 guru (66\%) mengatakan setuju dan 4 (10\%) guru mengatakan kurang setuju.

m) Pertanyaan nomor 13, tanggapan dari 100 guru, sebanyak 34 guru (34\%) mengatakan sangat setuju bahwa mereka menggunakan beberapa metode penilaian untuk memantau kemajuan siswa, 
sebanyak 57 guru (57\%) mengatakan setuju dan 9 guru (9\%) mengatakan kurang setuju

n) Pertanyaan nomor 14, jawaban dari 100 guru, 28 guru (28\%) menyatakan sangat setuju bahwa mereka memanfaatkan hasil evaluasi pembelajaran, sebanyak 68 guru (68\%) mengatakan setuju dan $4(4 \%)$ guru mengatakan kurang setuju.

\section{B. Uji Prasyarat Regresi}

Sebelum melakukan pengujian hipotesis, dilakukan pengujian prasyarat asumsi klasik. Pengujian asumsi klasik pada penelitian ini meliputi: uji normalitas, uji linieritas dan uji multikolinieritas.

\section{Uji Normalitas}

Uji normalitas dilakukan untuk mengetahui normal apa tidaknya suatu distribusi data normal atau tidaknya, sehingga jawaban dari responden bisa dinyatakan mewakili seluruh populasi. Jika distribusi data tidak normal, maka kelompok data tersebut tidak dapat dilakukan uji hipotesis.

Berdasarkan grafik hasil uji normalitas, data tersebar di sekitar garis diagonal dan bentuk histogram, dengan demikian model regresi memenuhi asumsi normalitas dan layak dipakai untuk memprediksi kinerja guru berdasarkan masukan variabel lingkungan kerja, motivasi kerja dan kepuasan kerja, hasil uji One-Sampel Kolmogorov-Smirnov menyatakan nilai Asymp. Sig. (2-tailed) yang > 0,05 sehingga bisa dikatakan keempat variabel tersebut 
berdistribusi normal. berikut ini tabel uji One-Sample Kolmogorov-Smirnov Test:

Tabel 4.9:

Hasil Uji Normalitas

\begin{tabular}{|l|c|}
\hline \multicolumn{1}{|c|}{ Variabel } & Asymp. Sig \\
\hline Lingkungan Kerja & 0.195 \\
\hline Motivasi Kerja & 0.846 \\
\hline Kepuasan Kerja & 0.085 \\
\hline Kinerja Guru & 0.970 \\
\hline
\end{tabular}

Berdasarkan hasil uji normalitas diketahui bahwa nilai Asymp. Sig. (2tailed) variabel lingkungan kerja adalah 0,195, nilai Asymp. Sig. (2-tailed) variabel Motivasi kerja 0,846, nilai Asymp. Sig. (2-tailed) variabel kepuasan kerja 0,085, dan nilai Asymp. Sig. (2-tailed) variabel kinerja guru 0,970 karena nilai Asymp. Sig. (2-tailed) >0,05 maka keempat variabel tersebut berdistribusi normal.

\section{Uji Linieritas}

Hasil uji coba linierilitas data dalam penelitian ini diketahui bahwa nilai signifikansi variabel lingkungan kerja terhadap kinerja guru sebesar 0.17 dan variabel motivasi kerja sebesar 0.058 dan variabel kepuasan kerja sebesar 0.053. Dengan demikian, maka dapat dinyatakan bahwa nilai signifikansi dari semua variabel lebih besar dari 0,05.

Sedangkan Hasil uji coba linierilitas data dalam penelitian ini diketahui bahwa nilai signifikansi variabel lingkungan kerja terhadap kepuasan kerja guru sebesar 0.051 dan variabel motivasi kerja sebesar 0.09. Dengan demikian, maka dapat dinyatakan bahwa nilai signifikansi dari semua variabel lebih besar dari 0,05 . 
Tabel 4.10: Hasil Uji Linearitas

\begin{tabular}{|c|c|c|c|c|c|}
\hline No. & Variabel & Signifikansi & Alpha & Kondisi & kesimpulan \\
\hline 1 & $\mathrm{Kg} * \mathrm{Lk}$ & 0.17 & 0.05 & $\mathrm{~S}>\mathrm{A}$ & Linear \\
\hline 2 & $\mathrm{Kg} * \mathrm{Mk}$ & 0.053 & & & \\
\hline 3 & $\mathrm{Kg} * \mathrm{Kk}$ & 0.053 & & & \\
\hline 4 & $\mathrm{Kk} * \mathrm{Lk}$ & 0.051 & & & \\
\hline 5 & $\mathrm{Kk} * \mathrm{Mk}$ & 0.09 & & & \\
\hline
\end{tabular}

\section{Uji Multikolinieritas}

Tujuan Uji multikolinieritas adalah menguji apakah model regresi ditemukan adanya korelasi antar variabel bebas (independent variable). Model regresi yang baik seharusnya tidak terjadi korelasi di antara variabel

Tabel 4.11:

Hasil Uji Multikolinieritas

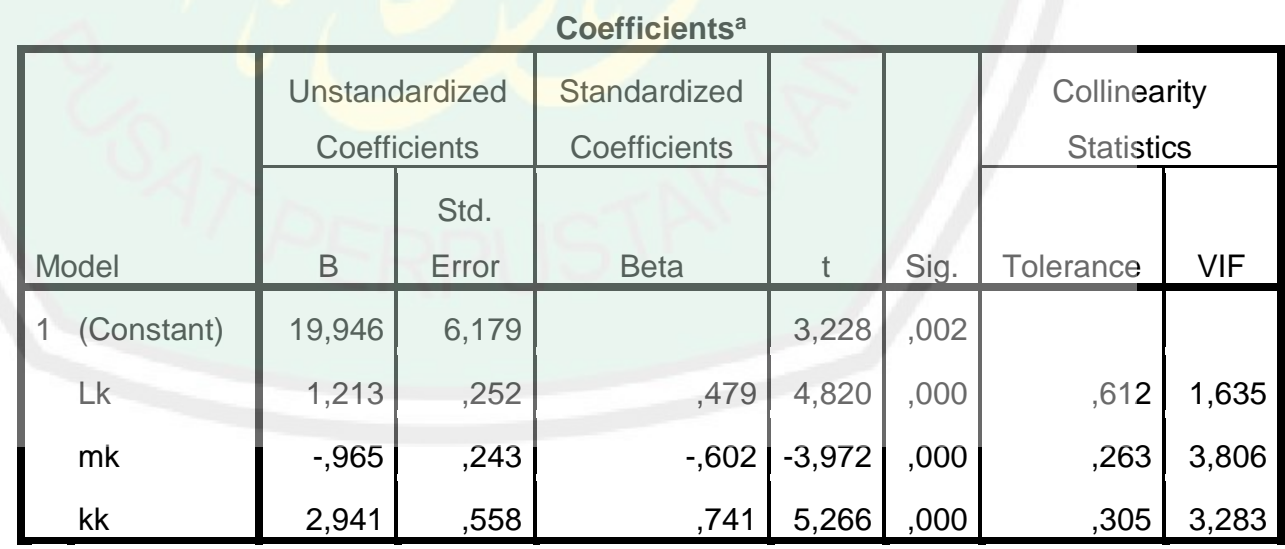

a. Dependent Variable: kg 


\begin{tabular}{|c|c|c|c|c|c|c|c|}
\hline \multirow[b]{2}{*}{ Model } & \multicolumn{2}{|c|}{$\begin{array}{c}\text { Unstandardized } \\
\text { Coefficients } \\
\end{array}$} & \multirow{2}{*}{$\begin{array}{c}\text { Standardized } \\
\text { Coefficients } \\
\text { Beta }\end{array}$} & \multirow[b]{2}{*}{$\mathrm{t}$} & \multirow[b]{2}{*}{ Sig. } & \multicolumn{2}{|c|}{ Collinearity Statistics } \\
\hline & $\mathrm{B}$ & Error & & & & Tolerance & VIF \\
\hline 1 (Constant) & 1,972 & 1,106 & & 1,783 & ,078 & & \\
\hline Lk & ,020 & ,046 & ,032 & ,443 & ,659 & ,613 & 1,631 \\
\hline Mk & ,329 & ,029 & ,814 & 11,371 & ,000 & ,613 & 1,631 \\
\hline
\end{tabular}

a. Dependent Variable: kk

Hasil uji coba multikolinieritas sebagaimana dalam tabel di atas, maka besaran nilai VIF untuk variabel lingkungan kerja terhadap kinerja adalah 1,635 dan nilai toleransi sebesar 0,612 . Sedangkan untuk variabel motivasi kerja terhadap kinerja maka akan terlihat besaran nilai VIF sebesar 3,806 dan nilai toleransi adalah 0,263. Sedangkan untuk variabel motivasi kerja terhadap kinerja maka akan terlihat besaran nilai VIF sebesar 3,283 dan nilai toleransi adalah 0,305. Hasil uji tersebut mengindikasikan bahwa nilai VIF mendekati 1 untuk semua variabel bebas. Demikian pula dengan nilai tolerance yang mendekati 1 untuk semua variabel bebas. Dengan demikian, maka model regresi dalam penelitian ini tidak terdapat problem multikolinieritas antar variabel bebas dan layak digunakan sebagai model regresi.

\section{Pengujian Hipotesis}

Setelah data melalui tahap penyajian deskriptif dan tahap uji prasyarat maka selanjutnya dilakukan pengujian hipotesis. pengujian hipotesis dalam penelitian ini menggunakan metode analisis jalur.

Pengujian hipotesis ini bertujuan untuk mengetahui ada atau tidaknya pengaruh langsung variabel lingkungan kerja, dan motivasi kerja terhadap 
kinerja guru dan pengaruh tidak langsung kedua variabel tersebut terhadap kinerja guru melalui kepuasan kerja. Dalam pengujian hipotesis penelitian ini penulis menggunakan multiple regression analisys dengan menggunakan bantuan program SPSS (Statistical Product and Service Solutions) 23 for Windows.

Hipotesis yang diuji dalam penelitian ini adalah hipotesis $\left(\mathrm{H}_{0}\right)$ yang menyatakan tidak ada pengaruh lingkungan kerja terhadap kepuasan kerja guru Madrasah Aliyah di Pulau Bawean, tidak ada pengaruh motivasi kerja terhadap kepuasan kerja guru Madrasah Aliyah di Pulau Bawean, tidak ada pengaruh lingkungan terhadap kinerja guru Madrasah Aliyah di Pulau Bawean, tidak ada pengaruh motivasi kerja terhadap kinerja guru Madrasah Aliyah di Pulau Bawean, tidak ada pengaruh kepuasan kerja terhadap kinerja guru Madrasah Aliyah di Pulau Bawean, tidak ada pengaruh tidak langsung lingkungan kerja dengan kinerja guru melalui kepuasan kerja guru dan tidak ada pengaruh tidak langsung motivasi kerja dengan kinerja guru melalui kepuasan kerja guru

Sedangkan uji hipotesis alternatif $\left(\mathrm{H}_{1}\right)$ yang menyatakan ada pengaruh lingkungan kerja terhadap kepuasan kerja guru Madrasah Aliyah di Pulau Bawean, ada pengaruh motivasi kerja terhadap kepuasan kerja guru Madrasah Aliyah di Pulau Bawean, ada pengaruh lingkungan terhadap kinerja guru Madrasah Aliyah di Pulau Bawean, ada pengaruh motivasi kerja terhadap kinerja guru Madrasah Aliyah di Pulau Bawean, ada pengaruh kepuasan kerja terhadap kinerja guru Madrasah Aliyah di Pulau Bawean, ada pengaruh tidak langsung lingkungan kerja dengan kinerja guru melalui kepuasan kerja guru dan ada 
pengaruh tidak langsung motivasi kerja dengan kinerja guru melalui kepuasan kerja guru.

Uji hipotesis dilakukan dengan membandingkan probabilitas yang didapat dengan taraf signifikansi 0,05 dengan cara pengambilan keputusan apabila probabilitas yang diperoleh $>0,05$ maka $\mathrm{H}_{0}$ diterima dan sebaliknya apabila probabilitas $<0,05$ maka $\mathrm{H}_{1}$ yang diterima.

\section{Uji Regresi Linier Secara Parsial}

Uji regresi linier secara parsial dimaksudkan untuk mengetahui hubungan antara masing-masing variabel bebas (independent variabel) yang dalam hal ini adalah pengaruh lingkungan kerja terhadap kepuasan kerja guru dan pengaruh motivasi kerja terhadap terhadap kepuasan kerja guru, pengaruh lingkungan kerja terhadap kinerja guru dan pengaruh motivasi kerja terhadap terhadap kinerja guru, serta pengaruh kepuasan kerja terhadap kinerja guru. Dari uji regresi linear secara parsial ini maka diperoleh hasil analisis sebagai berikut :

1. Linier Berganda

Tabel 4.12: Hasil Uji Lineir Secara Parsial

\begin{tabular}{|c|c|c|c|c|}
\hline No & $\begin{array}{l}\text { Hipotesis Nol } \\
\text { (Ho) dan } \\
\text { Hipotesis } \\
\text { Alternatif }\left(\mathbf{H}_{1}\right)\end{array}$ & Data & Nilai & Kesimpulan \\
\hline 1 & $\begin{array}{c}\mathrm{H}_{1} \text { : } \\
\text { lingkukin baik } \\
\text { kerja, maka } \\
\text { akan } \\
\text { semakin } \\
\text { tinggi } \\
\text { kepuasan } \\
\text { kerja guru }\end{array}$ & $\begin{array}{l}\mathrm{T}_{\text {hitung }} \quad= \\
2,050 \\
\mathrm{~T}_{\text {tabel }}(100 ; \\
0,05)= \\
1,983 \\
\text { Probabilitas } \\
(\text { Sig. })=0,043\end{array}$ & $\begin{array}{l}\text { Prob < } \\
0,05 \\
\mathrm{~T}_{\text {hitung }} \\
>\mathrm{T}_{\text {tabel }}\end{array}$ & $\begin{array}{l}\mathrm{H}_{0} \text { ditolak } \\
\mathrm{H}_{1} \text { diterima }\end{array}$ \\
\hline
\end{tabular}




\begin{tabular}{|c|c|c|c|c|}
\hline & \begin{tabular}{ll}
$\mathrm{H}_{0}:$ & \multicolumn{1}{c}{ semakin } \\
& buruk \\
& lingkungan \\
& kerja, maka \\
akan & \\
semakin & tinggi \\
kepuasan \\
kerja guru
\end{tabular} & & & \\
\hline 2 & $\begin{aligned} \mathrm{H}_{1} \text { : } & \text { semakin } \\
& \text { tinggi } \\
& \text { motivasi } \\
& \text { kerja, maka } \\
& \text { akan } \\
& \text { semakin } \\
& \text { tinggi } \\
& \text { kepuasan } \\
& \text { kerja guru } \\
\mathrm{H}_{0}: & \quad \text { semakin } \\
& \text { rendah } \\
& \text { motivasi } \\
& \text { kerja, maka } \\
& \text { akan } \\
& \text { semakin } \\
& \text { rendah } \\
& \text { kepuasan } \\
& \text { kerja guru }\end{aligned}$ & $\begin{array}{l}\mathrm{T}_{\text {hitung }}= \\
11,371 \\
\mathrm{~T}_{\text {tabel }}(100 ; \\
0,05)= \\
1,983 \\
\text { Probabilitas } \\
\text { (Sig.) }=0,000\end{array}$ & $\begin{array}{l}\text { Prob < } \\
0,05 \\
\mathrm{~T}_{\text {hitung }} \\
>\mathrm{T}_{\text {tabel }}\end{array}$ & $\begin{array}{l}\mathrm{H}_{0} \text { ditolak } \\
\mathrm{H}_{1} \text { diterima }\end{array}$ \\
\hline 3 & $\begin{array}{c}\mathrm{H}_{1} \text { : } \text { semakin baik } \\
\text { lingkungan } \\
\text { kerja, maka } \\
\text { akan } \\
\text { semakin } \\
\text { tinggi } \\
\quad \text { kinerja guru } \\
\mathrm{H}_{0} \text { : semakin } \\
\quad \text { buruk } \\
\quad \text { lingkungan } \\
\text { kerja, maka } \\
\text { akan } \\
\text { semakin } \\
\text { rendah } \\
\text { kinerja guru }\end{array}$ & $\begin{array}{l}\mathrm{T}_{\text {hitung }} \quad= \\
4,820 \\
\mathrm{~T}_{\text {tabel }}(100 ; \\
0,05)= \\
1,983 \\
\text { Probabilitas } \\
(\text { Sig. })=0,000\end{array}$ & $\begin{array}{l}\text { Prob < } \\
0,05 \\
\mathrm{~T}_{\text {hitung }} \\
>\mathrm{T}_{\text {tabel }}\end{array}$ & $\begin{array}{l}\mathrm{H}_{0} \text { ditolak } \\
\mathrm{H}_{1} \text { diterima }\end{array}$ \\
\hline 4 & $\begin{array}{l}\mathrm{H}_{1}: \text { semakin } \\
\quad \text { tinggi } \\
\text { motivasi } \\
\text { kerja, maka }\end{array}$ & $\begin{array}{l}\mathrm{T}_{\text {hitung }}= \\
3,972\end{array}$ & $\begin{array}{l}\text { Prob < } \\
0,05 \\
\mathrm{~T}_{\text {hitung }} \\
>\mathrm{T}_{\text {tabel }}\end{array}$ & $\begin{array}{l}\mathrm{H}_{0} \text { ditolak } \\
\mathrm{H}_{1} \text { diterima }\end{array}$ \\
\hline
\end{tabular}




\begin{tabular}{|c|c|c|c|c|}
\hline & $\begin{array}{l}\text { akan } \\
\text { semakin } \\
\text { tinggi } \\
\text { kinerja guru } \\
\mathrm{H}_{0} \text { : } \text { semakin } \\
\quad \text { rendah } \\
\text { motivasi } \\
\text { kerja, maka } \\
\text { akan } \\
\text { semakin } \\
\text { rendah } \\
\text { kinerja guru }\end{array}$ & $\begin{array}{l}T_{\text {tabel }}(100 ; \\
0,05)= \\
1,983 \\
\text { Probabilitas } \\
(\text { Sig. })=0,000\end{array}$ & & \\
\hline 5 & $\begin{array}{l}\mathrm{H}_{1} \text { : } \text { semakin } \\
\text { tinggi } \\
\text { kepuasan } \\
\text { kerja guru, } \\
\text { maka akan } \\
\text { semakin } \\
\text { tinggi } \\
\text { kinerja guru } \\
\mathrm{H}_{0}: \quad \text { semakin } \\
\text { rendah } \\
\text { kepuasan } \\
\text { kerja guru, } \\
\text { maka akan } \\
\text { semakin } \\
\text { rendah } \\
\text { kinerja guru }\end{array}$ & $\begin{array}{l}\mathrm{T}_{\text {hitung }} \quad= \\
5,266 \\
\mathrm{~T}_{\text {tabel }}(100 ; \\
0,05)= \\
1,983 \\
\text { Probabilitas } \\
(\text { Sig. })=0,000\end{array}$ & $\begin{array}{l}\text { Prob < } \\
0,05 \\
\mathrm{~T}_{\text {hitung }} \\
>\mathrm{T}_{\text {tabel }}\end{array}$ & $\begin{array}{l}\mathrm{H}_{0} \text { ditolak } \\
\mathrm{H}_{1} \text { diterima }\end{array}$ \\
\hline
\end{tabular}

Berdasarkan tabel di atas, maka pengujian hipotesis nol yang pertama ditolak berdasar nilai signifikansi t yang didapat dalam variabel lingkungan kerja adalah 0,043 sehingga nilai tersebut bisa dinyatakan lebih kecil dari probabilitas $\alpha$ yang telah ditetapkan yaitu 0,05. Dengan demikian, nilai Sig.t $0,043<0,05$ sehingga menunjukan adanya penolakan terhadap $\mathrm{H}_{0}$ dan penerimaan terhadap $\mathrm{H}_{1}$. Penerimaan $\mathrm{H}_{1}$ tersebut memberi arti bahwa lingkungan kerja berpengaruh terhadap kepuasan kerja guru Madrasah Aliyah di Pulau Bawean. 
Hasil uji hipotesis yang kedua yang menunjukkan adanya penerimaan terhadap $\mathrm{H}_{1}$. Nilai signifikansi untuk variabel motivasi kerja sebesar 0,000 sehingga bisa dinyatakan bahwa nilai tersebut lebih kecil dari probabilitas $\alpha$ yang telah ditetapkan yang dalam hal ini yaitu 0,05 . Dengan demikian, nilai Sig.t $0,000<0,05$ sehingga menunjukan adanya penerimaan terhadap $\mathrm{H}_{1}$ dan penolakan terhadap $\mathrm{H}_{0}$ dan menyatakan bahwa motivasi kerja berpengaruh terhadap kepuasan kerja guru Madrasah Aliyah di Pulau Bawean.

Lebih jelasnya mengenai uji hipotesis secara parsial untuk hipotesis pertama dan kedua lihat tabel berikut ini :

\begin{tabular}{|c|c|c|c|c|c|}
\hline \multirow[b]{2}{*}{ Model } & \multicolumn{2}{|c|}{$\begin{array}{c}\text { Unstandardized } \\
\text { Coefficients }\end{array}$} & $\begin{array}{l}\text { Standardized } \\
\text { Coefficients }\end{array}$ & \multirow[b]{2}{*}{$\mathrm{T}$} & \multirow[b]{2}{*}{ Sig. } \\
\hline & B & Std. Error & Beta & & \\
\hline 1 (Constant) & 1,972 & 1,106 & & 1,783 & ,078 \\
\hline$x 1$ &, 120 & ,04 &, $1<$ & 2,050 & ,043 \\
\hline$x 2$ & ,329 & ,029 & ,8 & 11,371 & ,000 \\
\hline
\end{tabular}

a. Dependent Variable: $z$

Tabel di atas menjelaskan bahwa persamaan regresi diperoleh dari rumusan berikut :

$Z=a+b_{1} X_{1}+b_{2} X_{2}+b_{3} X_{3}$

Kepuasan Kerja Guru $\left(X_{3}\right)=1.972+0.120\left(\mathrm{X}_{1}\right)+0.329\left(\mathrm{X}_{2}\right)$.

Dalam persamaan regresi tersebut, standar kesalahan yang didapat sebesar 1.106 untuk beta nol. Sedangkan standar error persamaan regresi variabel lingkungan kerja adalah 0.040, variabel motivasi kerja sebesar 0,029, Adapun nilai signifikansi t test variabel lingkungan kerja adalah 2.050 dengan 
nilai Sig sebesar 0,043, dan variabel motivasi kerja sebesar 11.371 dengan nilai Sig sebesar 0,000. Nilai signifikansi $t$ tersebut menunjukkan bahwa nilai signifikansi variabel Lingkungan kerja lebih kecil dari nilai probabilitas yang ditetapkan sebesar 0,05 dan nilai signifikansi variabel motivasi kerja lebih kecil dari nilai probabilitas yang ditetapkan. Dengan demikian dapat disimpulkan bahwa lingkungan kerja secara parsial berpengaruh terhadap kepuasan kerja guru, dan mortivasi kerja secara parsial berpengaruh terhadap kepuasan kerja guru Madrasah Aliyah di Pulau Bawean.

Sedangkan Hasil uji hipotesis yang ketiga yang menunjukkan adanya penerimaan terhadap $\mathrm{H}_{1}$. Nilai signifikansi untuk variabel lingkungan kerja sebesar 0,000 sehingga bisa dinyatakan bahwa nilai tersebut lebih kecil dari probabilitas $\alpha$ yang telah ditetapkan yang dalam hal ini yaitu 0,05 . Dengan demikian, nilai Sig.t 0,000 < 0,05 sehingga menunjukan adanya penerimaan terhadap $\mathrm{H}_{1}$ dan penolakan terhadap $\mathrm{H}_{0}$ dan menyatakan bahwa motivasi kerja berpengaruh terhadap kinerja guru Madrasah Aliyah di Pulau Bawean.

Hasil uji hipotesis yang keempat yang menunjukkan adanya penerimaan terhadap $\mathrm{H}_{1}$. Nilai signifikansi untuk variabel motivasi kerja sebesar 0,000 sehingga bisa dinyatakan bahwa nilai tersebut lebih kecil dari probabilitas $\alpha$ yang telah ditetapkan yang dalam hal ini yaitu 0,05 . Dengan demikian, nilai Sig.t 0,000 $<0,05$ sehingga menunjukan adanya penerimaan terhadap $\mathrm{H}_{1}$ dan penolakan terhadap $\mathrm{H}_{0}$ dan menyatakan bahwa motivasi kerja berpengaruh terhadap kinerja guru Madrasah Aliyah di Pulau Bawean. 
Hasil uji hipotesis yang kedua yang menunjukkan adanya penerimaan terhadap $\mathrm{H}_{1}$. Nilai signifikansi untuk variabel kepuasan kerja sebesar 0,000 sehingga bisa dinyatakan bahwa nilai tersebut lebih kecil dari probabilitas $\alpha$ yang telah ditetapkan yang dalam hal ini yaitu 0,05 . Dengan demikian, nilai Sig.t $0,000<0,05$ sehingga menunjukan adanya penerimaan terhadap $\mathrm{H}_{1}$ dan penolakan terhadap $\mathrm{H}_{0}$ dan menyatakan bahwa motivasi kerja berpengaruh terhadap kinerja guru Madrasah Aliyah di Pulau Bawean.

Lebih jelasnya mengenai uji hipotesis secara parsial untuk hipotesis ketiga, keempat dan kelima lihat tabel berikut ini :

\begin{tabular}{|c|r|r|r|r|r|}
\hline & Unstandardized Coefficients & Standardized Coefficients & & \\
\cline { 2 - 5 } Model & B & Std. Error & Beta & t & Sig. \\
\hline 1 (Constant) & 19,946 & 6,179 & & 3,228 &, 002 \\
x1 & 1,213 &, 252 &, 479 & 4,820 &, 000 \\
x2 &, 965 &, 243 &, 602 & 3,972 &, 000 \\
Z & 2,941 &, 558 &, 741 & 5,266 &, 000 \\
\hline
\end{tabular}

a. Dependent Variable: y

Tabel di atas menjelaskan bahwa persamaan regresi diperoleh dari rumusan berikut :

$Z=a+b_{1} X_{1}+b_{2} X_{2}+b_{3 Z}$

Kepuasan Kerja Guru $\left(X_{3}\right)=19.946+1.213\left(\mathrm{X}_{1}\right)+0.965\left(\mathrm{X}_{2}\right)+2.941(\mathrm{Z})$

Dalam persamaan regresi tersebut, standar kesalahan yang didapat sebesar 6.179 untuk beta nol. Sedangkan standar error persamaan regresi variabel lingkungan kerja adalah 0.252 , variabel motivasi kerja sebesar 0,243 
dan kepuasan kerja sebesar 0,558, Adapun nilai signifikansi t test variabel lingkungan kerja adalah 4.820 dengan nilai Sig sebesar 0,000, variabel motivasi kerja sebesar 3.972 dengan nilai Sig sebesar 0,000 dan variabel kepuasan kerja sebesar 5.266 dengan nilai Sig sebesar 0,000. Nilai signifikansi $t$ tersebut menunjukkan bahwa nilai signifikansi variabel lingkungan kerja lebih kecil dari nilai probabilitas yang ditetapkan sebesar 0,05 dan nilai signifikansi variabel motivasi kerja lebih kecil dari nilai probabilitas yang ditetapkan begitu juga dengan variabel kepuasan kerja lebih kecil daripada probabilitas yang ditetapkan.. Dengan demikian dapat disimpulkan bahwa lingkungan kerja secara parsial berpengaruh terhadap kinerja guru, dan mortivasi kerja secara parsial berpengaruh terhadap kinerja guru Madrasah Aliyah di Pulau Bawean, begitu juga mortivasi kerja secara parsial berpengaruh terhadap kinerja guru Madrasah Aliyah di Pulau Bawean

2. linear sederhana

\begin{tabular}{|c|c|c|c|c|}
\hline No. & $\begin{array}{c}\text { Hipotesis Nol } \\
\text { (Ho) dan } \\
\text { Hipotesis } \\
\text { Alternatif }\left(\mathrm{H}_{1}\right)\end{array}$ & Data & Nilai & Kesimpulan \\
\hline 1 & $\begin{array}{c}\mathrm{H}_{1}: \text { semakin } \\
\text { baik } \\
\text { lingkungan } \\
\text { kerja, maka } \\
\text { akan } \\
\text { semakin } \\
\text { tinggi } \\
\text { kepuasan } \\
\text { kerja guru } \\
\mathrm{H}_{0}: \text { semakin } \\
\text { buruk } \\
\text { lingkungan }\end{array}$ & $\begin{array}{l}\text { Thitung = } \\
6,318 \\
\text { Ttabel }(100 ; \\
0,05)= \\
1,983 \\
\text { Probabilitas } \\
(\text { Sig. })=0,000\end{array}$ & $\begin{array}{l}\text { Prob < } \\
0,05 \\
\mathrm{~T}_{\text {hitung }} \\
>\mathrm{T}_{\text {tabel }}\end{array}$ & $\begin{array}{l}\mathrm{H}_{0} \text { ditolak } \\
\mathrm{H}_{1} \text { diterima }\end{array}$ \\
\hline
\end{tabular}




\begin{tabular}{|c|c|c|c|c|}
\hline & $\begin{array}{l}\text { kerja, maka } \\
\text { akan } \\
\text { semakin } \\
\text { tinggi } \\
\text { kepuasan } \\
\text { kerja guru }\end{array}$ & & & \\
\hline 2 & $\begin{aligned} \mathrm{H}_{1} \text { :semakin } & \text { tinggi } \\
& \text { motivasi } \\
& \text { kerja, maka } \\
& \text { akan } \\
& \text { semakin } \\
& \text { tinggi } \\
& \text { kepuasan } \\
& \text { kerja guru } \\
\mathrm{H}_{0}: & \quad \text { semakin } \\
& \text { rendah } \\
& \text { motivasi } \\
& \text { kerja, maka } \\
& \text { akan } \\
& \text { semakin } \\
& \text { rendah } \\
& \text { kepuasan } \\
& \text { kerja guru }\end{aligned}$ & $\begin{array}{l}T_{\text {hitung }}= \\
14,937 \\
\mathrm{~T}_{\text {tabel }}(100 ; \\
0,05)= \\
1,983 \\
\text { Probabilitas } \\
(\text { Sig. })=0,000\end{array}$ & $\begin{array}{l}\text { Prob < } \\
0,05 \\
\mathrm{~T}_{\text {hitung }} \\
>\mathrm{T}_{\text {tabel }}\end{array}$ & $\begin{array}{l}\mathrm{H}_{0} \text { ditolak } \\
\mathrm{H}_{1} \text { diterima }\end{array}$ \\
\hline 3 & $\begin{array}{l}\mathrm{H}_{1} \text { :semakin } \\
\text { baik } \\
\text { lingkungan } \\
\text { kerja, maka } \\
\text { akan } \\
\quad \text { semakin } \\
\quad \text { tinggi } \\
\quad \text { kinerja guru } \\
\mathrm{H}_{0} \text { : } \quad \text { semakin } \\
\quad \text { buruk } \\
\text { lingkungan } \\
\text { kerja, maka } \\
\text { akan } \\
\text { semakin } \\
\text { rendah } \\
\text { kinerja guru }\end{array}$ & $\begin{array}{l}\mathrm{T}_{\text {hitung }} \quad= \\
5,763 \\
\mathrm{~T}_{\text {tabel }}(100 ; \\
0,05)= \\
1,983 \\
\text { Probabilitas } \\
\text { (Sig.) }=0,000\end{array}$ & $\begin{array}{l}\text { Prob < } \\
0,05 \\
\mathrm{~T}_{\text {hitung }} \\
>\mathrm{T}_{\text {tabel }}\end{array}$ & $\begin{array}{l}\mathrm{H}_{0} \text { ditolak } \\
\mathrm{H}_{1} \text { diterima }\end{array}$ \\
\hline 4 & $\begin{array}{l}\mathrm{H}_{1}: \text { semakin } \\
\quad \text { tinggi } \\
\text { motivasi } \\
\text { kerja, maka } \\
\text { akan } \\
\text { semakin }\end{array}$ & $\begin{array}{l}\mathrm{T}_{\text {hitung }} \quad= \\
3,272 \\
\mathrm{~T}_{\text {tabel }}(100 ; \\
0,05)= \\
1,983\end{array}$ & $\begin{array}{l}\text { Prob < } \\
0,05 \\
\mathrm{~T}_{\text {hitung }} \\
>\mathrm{T}_{\text {tabel }}\end{array}$ & $\begin{array}{l}\mathrm{H}_{0} \text { ditolak } \\
\mathrm{H}_{1} \text { diterima }\end{array}$ \\
\hline
\end{tabular}




\begin{tabular}{|c|c|c|c|c|}
\hline & $\begin{array}{l}\text { tinggi } \\
\text { kinerja guru } \\
\mathrm{H}_{0}: \quad \text { semakin } \\
\quad \text { rendah } \\
\text { motivasi } \\
\quad \text { kerja, maka } \\
\text { akan } \\
\text { semakin } \\
\text { rendah } \\
\text { kinerja guru }\end{array}$ & $\begin{array}{l}\text { Probabilitas } \\
(\text { Sig. })=0,001\end{array}$ & & \\
\hline 5 & $\begin{array}{c}\mathrm{H}_{1} \text { :semakin } \\
\text { tinggi } \\
\text { kepuasan } \\
\text { kerja guru, } \\
\text { maka akan } \\
\text { semakin } \\
\text { tinggi } \\
\text { kinerja guru } \\
\mathrm{H}_{0}: \quad \text { semakin } \\
\text { rendah } \\
\text { kepuasan } \\
\text { kerja guru, } \\
\text { maka akan } \\
\text { semakin } \\
\text { rendah } \\
\text { kinerja guru }\end{array}$ & $\begin{array}{l}\mathrm{T}_{\text {hitung }} \quad= \\
5,672 \\
\mathrm{~T}_{\text {tabel }}(100 ; \\
0,05)= \\
1,983 \\
\text { Probabilitas } \\
\text { (Sig.) }=0,000\end{array}$ & $\begin{array}{l}\text { Prob < } \\
0,05 \\
\mathrm{~T}_{\text {hitung }} \\
>\mathrm{T}_{\text {tabel }}\end{array}$ & $\begin{array}{l}\mathrm{H}_{0} \text { ditolak } \\
\mathrm{H}_{1} \text { diterima }\end{array}$ \\
\hline
\end{tabular}

Berdasarkan tabel di atas, maka pengujian hipotesis nol yang pertama ditolak berdasar nilai signifikansi t yang didapat dalam variabel lingkungan kerja adalah 0,000 sehingga nilai tersebut bisa dinyatakan lebih kecil dari probabilitas $\alpha$ yang telah ditetapkan yaitu 0,05. Dengan demikian, nilai Sig.t $0,000<0,05$ sehingga menunjukan adanya penolakan terhadap $\mathrm{H}_{0}$ dan penerimaan terhadap $\mathrm{H}_{1}$. Penerimaan $\mathrm{H}_{1}$ tersebut memberi arti bahwa lingkungan kerja berpengaruh terhadap kepuasan kerja guru Madrasah Aliyah di Pulau Bawean. 
Hasil uji hipotesis yang kedua yang menunjukkan adanya penerimaan terhadap $\mathrm{H}_{1}$. Nilai signifikansi untuk variabel motivasi kerja sebesar 0,000 sehingga bisa dinyatakan bahwa nilai tersebut lebih kecil dari probabilitas $\alpha$ yang telah ditetapkan yang dalam hal ini yaitu 0,05 . Dengan demikian, nilai Sig.t $0,000<0,05$ sehingga menunjukan adanya penerimaan terhadap $\mathrm{H}_{1}$ dan penolakan terhadap $\mathrm{H}_{0}$ dan menyatakan bahwa motivasi kerja berpengaruh terhadap kepuasan kerja guru Madrasah Aliyah di Pulau Bawean.

Sedangkan Hasil uji hipotesis yang ketiga yang menunjukkan adanya penerimaan terhadap $\mathrm{H}_{1}$. Nilai signifikansi untuk variabel lingkungan kerja sebesar 0,000 sehingga bisa dinyatakan bahwa nilai tersebut lebih kecil dari probabilitas $\alpha$ yang telah ditetapkan yang dalam hal ini yaitu 0,05 . Dengan demikian, nilai Sig.t 0,000 <0,05 sehingga menunjukan adanya penerimaan terhadap $\mathrm{H}_{1}$ dan penolakan terhadap $\mathrm{H}_{0}$ dan menyatakan bahwa motivasi kerja berpengaruh terhadap kinerja guru Madrasah Aliyah di Pulau Bawean.

Hasil uji hipotesis yang keempat yang menunjukkan adanya penerimaan terhadap $\mathrm{H}_{1}$. Nilai signifikansi untuk variabel motivasi kerja sebesar 0,001 sehingga bisa dinyatakan bahwa nilai tersebut lebih kecil dari probabilitas $\alpha$ yang telah ditetapkan yang dalam hal ini yaitu 0,05 . Dengan demikian, nilai Sig.t $0,001<0,05$ sehingga menunjukan adanya penerimaan terhadap $\mathrm{H}_{1}$ dan penolakan terhadap $\mathrm{H}_{0}$ dan menyatakan bahwa motivasi kerja berpengaruh terhadap kinerja guru Madrasah Aliyah di Pulau Bawean.

Hasil uji hipotesis yang kedua yang menunjukkan adanya penerimaan terhadap $\mathrm{H}_{1}$. Nilai signifikansi untuk variabel kepuasan kerja sebesar 0,000 
sehingga bisa dinyatakan bahwa nilai tersebut lebih kecil dari probabilitas $\alpha$ yang telah ditetapkan yang dalam hal ini yaitu 0,05 . Dengan demikian, nilai Sig.t $0,000<0,05$ sehingga menunjukan adanya penerimaan terhadap $\mathrm{H}_{1}$ dan penolakan terhadap $\mathrm{H}_{0}$ dan menyatakan bahwa motivasi kerja berpengaruh terhadap kinerja guru Madrasah Aliyah di Pulau Bawean.

\section{Uji Regresi Linier Secara Simultan}

Uji regresi linier secara simultan dimaksudkan untuk mengetahui pengaruh semua variabel bebas terhadap variabel intervening dan terikat. Dalam hal ini pengaruh lingkungan kerja, motivasi kerja terhadap kepuasan kerja guru Madrasah Aliyah di Pulau Bawean dan pengaruh lingkungan kerja, motivasi kerja dan kepuasan kerja guru terhadap kinerja guru Madrasah Aliyah di Pulau Bawean . Untuk lebih jelasnya, berikut dipaparkan hasil uji regresi linier berganda secara simultan.

Tabel 4.13: Hasil Uji Lineir Secara Simultan

\begin{tabular}{|c|c|c|c|c|}
\hline No & $\begin{array}{l}\text { Hipotesis Nol } \\
\left(\mathbf{H}_{0}\right) \text { dan } \\
\text { Hipotesis } \\
\text { Alternatif }\left(\mathbf{H}_{1}\right)\end{array}$ & Data & Nilai & Kesimpulan \\
\hline 1 & $\begin{array}{l}\mathrm{H}_{0} \text { : Tidak ada } \\
\text { pengaruh positif } \\
\text { dan signifikan } \\
\text { secara simultan } \\
\text { lingkungan } \\
\text { kerja, motivasi } \\
\text { kerja terhadap } \\
\text { kepuasan guru. } \\
\mathrm{H}_{1} \text { : ada pengaruh } \\
\text { positif dan } \\
\text { signifikan } \\
\text { secara simultan } \\
\text { lingkungan }\end{array}$ & $\begin{array}{l}F_{\text {hitung }}= \\
110,738 \\
\text { Ftabel }(3 ; \\
82 ; 0,05)= \\
3,09 \\
\text { Probabili } \\
\text { tas (Sig.) } \\
=0,000\end{array}$ & $\begin{array}{l}\text { Probabilitas< } \\
0,05 \\
\text { F Hitung }>\text { F } \\
\text { Tabel }\end{array}$ & $\begin{array}{l}\mathrm{H}_{0} \text { ditolak } \\
\mathrm{H}_{1} \text { diterima }\end{array}$ \\
\hline
\end{tabular}




\begin{tabular}{|c|c|c|c|}
\hline $\begin{array}{l}\text { kerja, motivasi } \\
\text { kerja terhadap } \\
\text { kepuasan guru }\end{array}$ & & & \\
\hline $\begin{array}{l}\mathrm{H}_{0} \text { : Tidak ada } \\
\text { pengaruh positif } \\
\text { dan signifikan } \\
\text { secara simultan } \\
\text { lingkungan } \\
\text { kerja, motivasi } \\
\text { kerja dan } \\
\text { kepuasan guru } \\
\text { terhadap kinerja } \\
\text { guru. } \\
\mathrm{H}_{1} \text { : Tidak ada } \\
\text { pengaruh positif } \\
\text { dan signifikan } \\
\text { secara simultan } \\
\text { lingkungan } \\
\text { kerja, motivasi } \\
\text { kerja dan } \\
\text { kepuasan guru } \\
\text { terhadap kinerja } \\
\text { guru. }\end{array}$ & $\begin{array}{l}F_{\text {hitung }}= \\
103,417 \\
\text { Ftabel }(3 ; \\
82 ; 0,05)= \\
3,09 \\
\text { Probabili } \\
\text { tas (Sig.) } \\
=0,000\end{array}$ & $\begin{array}{l}\text { Probabilitas< } \\
0,05 \\
\text { F Hitung }>\text { F } \\
\text { Tabel }\end{array}$ & $\begin{array}{l}\mathrm{H}_{0} \text { ditolak } \\
\mathrm{H}_{1} \text { diterima }\end{array}$ \\
\hline
\end{tabular}

Hasil pengujian hipotesis yang pertama secara simultan dalam penelitian ini menunjukkan bahwa nilai signifikansi uji serempak (uji F) sebesar 0,000. Dengan demikian maka nilai signifikansi F lebih kecil dari probabilitas $\alpha$ yang ditetapkan. Dengan demikian, nilai Sig.F $0,000<0,05$ sehingga menunjukan adanya penolakan terhadap $\mathrm{H}_{0}$ dan penerimaan terhadap $\mathrm{H}_{1}$ maka dinyatakan bahwa lingkungan dan motivasi kerja secara simultan berpengaruh terhadap kepuasan kerja guru Madrasah Aliyah di Pulau Bawean.

Hasil pengujian hipotesis yang kedua secara simultan dalam penelitian ini menunjukkan bahwa nilai signifikansi uji serempak (uji F) sebesar 0,000. Dengan demikian maka nilai signifikansi $\mathrm{F}$ lebih kecil dari probabilitas $\alpha$ 
yang ditetapkan. Dengan demikian, nilai Sig.F $0,000<0,05$ sehingga menunjukan adanya penolakan terhadap $\mathrm{H}_{0}$ dan penerimaan terhadap $\mathrm{H}_{1}$ maka dinyatakan bahwa lingkungan dan motivasi kerja serta kepuasan kerja guru secara simultan berpengaruh terhadap kinerja guru Madrasah Aliyah di Pulau Bawean

Lebih jelasnya mengenai hasil uji hipotesis secara simultan lihat tabel berikut:

\begin{tabular}{|c|c|c|c|c|c|c|}
\hline \multicolumn{2}{|c|}{ Model } & $\begin{array}{l}\text { Sum of } \\
\text { Squares }\end{array}$ & df & $\begin{array}{l}\text { Mean } \\
\text { Square }\end{array}$ & $\mathrm{F}$ & Sig. \\
\hline \multirow[t]{3}{*}{1} & $\begin{array}{l}\text { Regressio } \\
n\end{array}$ & 186,207 & 2 & 93,103 & 110,738 &, $000^{\mathrm{b}}$ \\
\hline & Residual & 81,553 & 97 & ,841 & & \\
\hline & Total & 267,760 & 99 & & & \\
\hline
\end{tabular}

a. Dependent Variable: Z

b. Predictors: (Constant), X1, X2

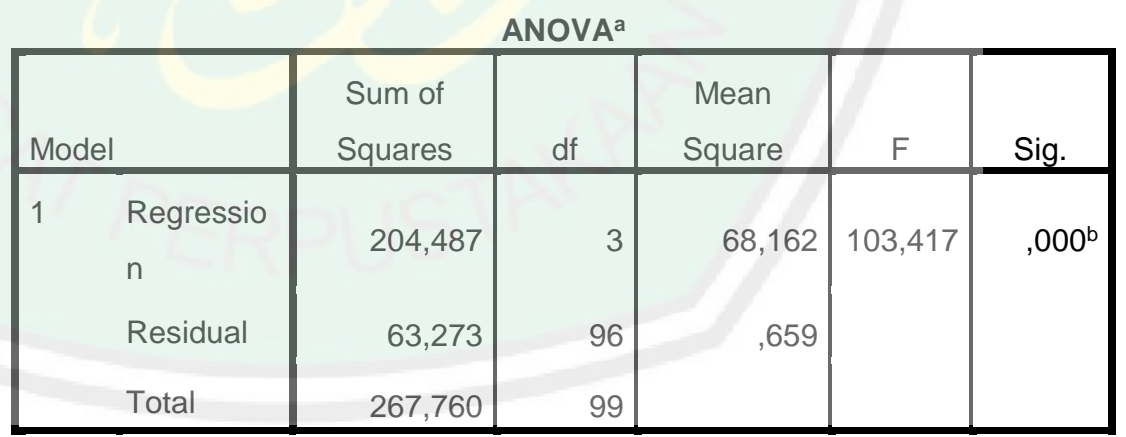

a. Dependent Variable: $Y$

b. Predictors: (Constant), X2, Z, X1 
Adapun kuatnya hubungan antara kedua prediktor dengan variabel kepuasan kerja adalah sebagaimana tabel berikut ini:

Model Summary

\begin{tabular}{|l|r|r|r|c|}
\hline Model & $\mathrm{R}$ & $\mathrm{R}$ Square & \multicolumn{1}{c|}{$\begin{array}{c}\text { Adjusted R } \\
\text { Square }\end{array}$} & $\begin{array}{c}\text { Std. Error of the } \\
\text { Estimate }\end{array}$ \\
\hline 1 &, $834^{\mathrm{a}}$ &, 695 &, 689 &, 91693 \\
\hline
\end{tabular}

a. Predictors: (Constant), X1, X2

Hasil analisis korelasi sebagaimana tabel di atas menjelaskan adanya output regresi yang menunjukkan pengaruh lingkungan kerja dan motivasi kerja terhadap kepuasan kerja guru diperoleh nilai R Square sebesar 0,695. Angka tersebut menunjukkan variasi nilai kepuasan kerja guru yang bisa dijelaskan oleh persamaan regresi yang diperoleh adalah sebesar 69,5\% sedangkan sisa 30,5\% dipengaruhi oleh variabel lain di luar persamaan model regresi yang diperoleh.

Adapun kuatnya hubungan antara ketiga prediktor dengan variabel kinerja guru adalah sebagaimana tabel berikut ini:

\begin{tabular}{|c|c|c|c|c|}
\hline & & & Model Summary \\
Model & $\mathrm{R}$ & $\mathrm{R}$ Square & $\begin{array}{c}\text { Adjusted R } \\
\text { Square }\end{array}$ & $\begin{array}{c}\text { Std. Error of the } \\
\text { Estimate }\end{array}$ \\
\hline 1 &, $648^{\mathrm{a}}$ &, 421 &, 402 & 5,04277 \\
\hline
\end{tabular}

a. Predictors: (Constant), z, x1, x2

Hasil analisis korelasi sebagaimana tabel di atas menjelaskan adanya output regresi yang menunjukkan pengaruh lingkungan kerja dan motivasi kerja terhadap kepuasan kerja guru diperoleh nilai R Square sebesar 0,421. Angka tersebut menunjukkan variasi nilai kinerja guru yang bisa dijelaskan 
oleh persamaan regresi yang diperoleh adalah sebesar $42,1 \%$ sedangkan sisa $58,9 \%$ dipengaruhi oleh variabel lain di luar persamaan model regresi yang diperoleh.

\section{Menghitung Koefisien jalur I}

Uji regresi linier di sini bertujuan untuk mengetahui hubungan antara masing-masing variabel bebas (independent variabel) yang dalam hal ini adalah lingkungan kerja dan motivasi kerja terhadap kepuasan kerja (variabel intervening) dan sumbangsih dari variabel $\mathrm{X}_{1}$ dan $\mathrm{X}_{2}$ terhadap Z. Dari uji hipotesis maka diperoleh hasil analisis sebagai berikut :

\begin{tabular}{|l|c|r|r|r|}
\hline Model & R & R Square & Adjusted R Square & Std. Error of the Estimate \\
\hline 1 &, $834^{\mathrm{a}}$ &, 695 &, 689 &, 91693 \\
\hline
\end{tabular}

a. Predictors: (Constant), x2, x1

\begin{tabular}{|c|c|c|c|c|c|}
\hline \multirow[b]{2}{*}{ Model } & \multicolumn{2}{|c|}{$\begin{array}{c}\text { Unstandardized } \\
\text { Coefficients }\end{array}$} & \multirow{2}{*}{$\begin{array}{c}\begin{array}{c}\text { Standardized } \\
\text { Coefficients }\end{array} \\
\text { Beta }\end{array}$} & \multirow[b]{2}{*}{ 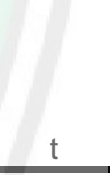 } & \multirow[b]{2}{*}{ Sig. } \\
\hline & B & Std. Error & & & \\
\hline 1 (Constant) & 1,972 & 1,106 & & 1,783 & ,078 \\
\hline$x 1$ &, 120 & ,04 &, 146 & 2,050 & ,043 \\
\hline$x 2$ & ,329 & & & & ,000, \\
\hline
\end{tabular}

a. Dependent Variable: $z$

Dari hasil analisis di atas diperoleh hasil bahwa nilai signifikansi dari kedua variabel yaitu $X_{1}=0,043$ dan $X_{2}=0,00$ dan kedua hasil signifikansi tersebut lebih kecil daripada 0,05. Jadi dapat diambil kesimpulan dari kedua variabel tersebut, baik $X_{1}$ maupun $X_{2}$ berpengaruh signifikan terhadap variabel Z. Sementara untuk nilai $e_{1}=\sqrt{ }(1-0,695)=0,305$, dari hasil tersebut maka dapat digambarkan diagram jalur 1 sebagai berikut: 
Gambar 4.5: Diagram Jalur 1

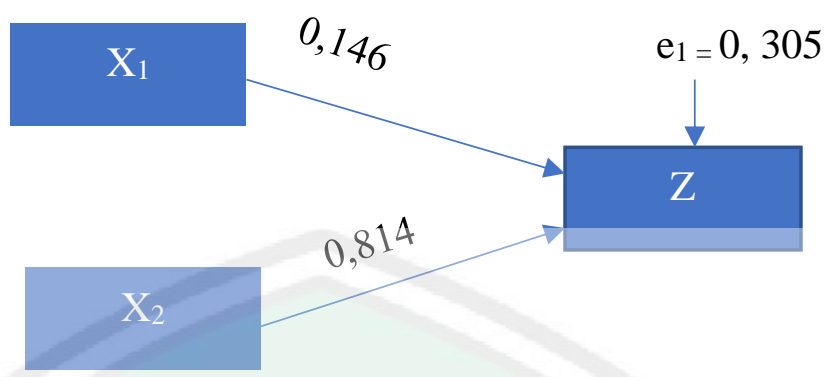

\section{Menghitung Koefisien jalur II}

Uji regresi linier di sini bertujuan untuk mengetahui hubungan antara masing-masing variabel bebas (independent variabel) yang dalam hal ini adalah lingkungan kerja dan motivasi kerja dan kepuasan kerja (variabel intervening) terhadap kinerja guru (dependent variabel) dan sumbangsih dari variabel $\mathrm{X}_{1}, \mathrm{X}_{2}$ dan $\mathrm{Z}$ terhadap $\mathrm{Y}$. Dari uji hipotesis maka diperoleh hasil analisis sebagai berikut :

\begin{tabular}{|c|c|c|c|c|}
\hline & & & & \\
Model & $R$ & $R$ Square & Adjusted R Square & $\begin{array}{c}\text { Std. Error of the } \\
\text { Estimate }\end{array}$ \\
\hline 1 &, $648^{\mathrm{a}}$ &, 421 &, 402 & 5,04277 \\
\hline
\end{tabular}

a. Predictors: (Constant), $\mathrm{z}, \mathrm{x} 1, \mathrm{x} 2$

Coefficients $^{a}$

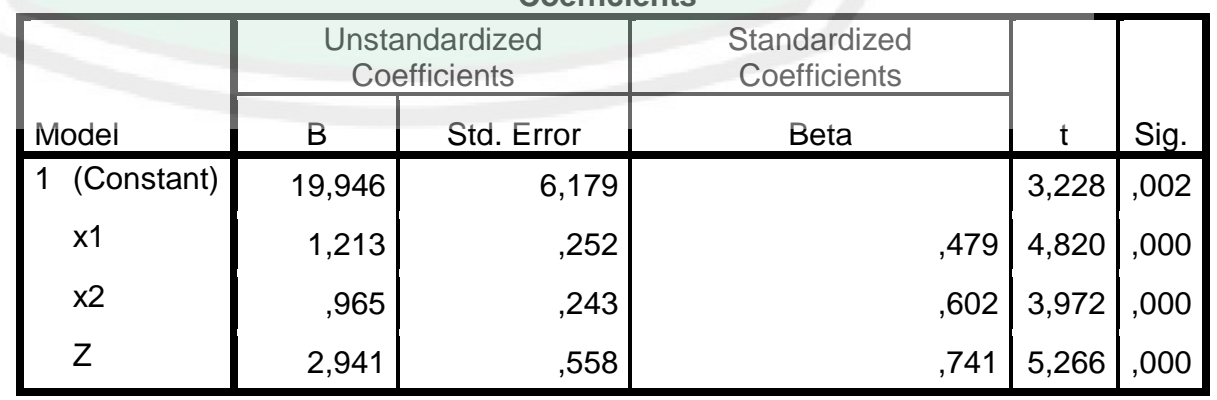


Dari hasil analisis di atas diperoleh hasil bahwa nilai signifikansi dari kedua variabel yaitu $X_{1}=0,000 X_{2}=0,000$ dan $Z=0,000$ dan ketiga hasil signifikansi tersebut lebih kecil daripada 0,05. Jadi dapat diambil kesimpulan dari kedua variabel tersebut, baik $\mathrm{X}_{1} \mathrm{X}_{2}$ maupun $\mathrm{Z}$ berpengaruh signifikan terhadap variabel Y. Besarnya nilai R Square yang terdapat pada Model Summary adalah sebesar 0,421 . Sementara untuk nilai $e_{2}=\sqrt{ }(1-0,421)=$ 0,761, dari hasil tersebut maka dapat digambarkan diagram jalur 2 sebagai berikut:

\section{Gambar 4.5: Diagram Jalur 2}

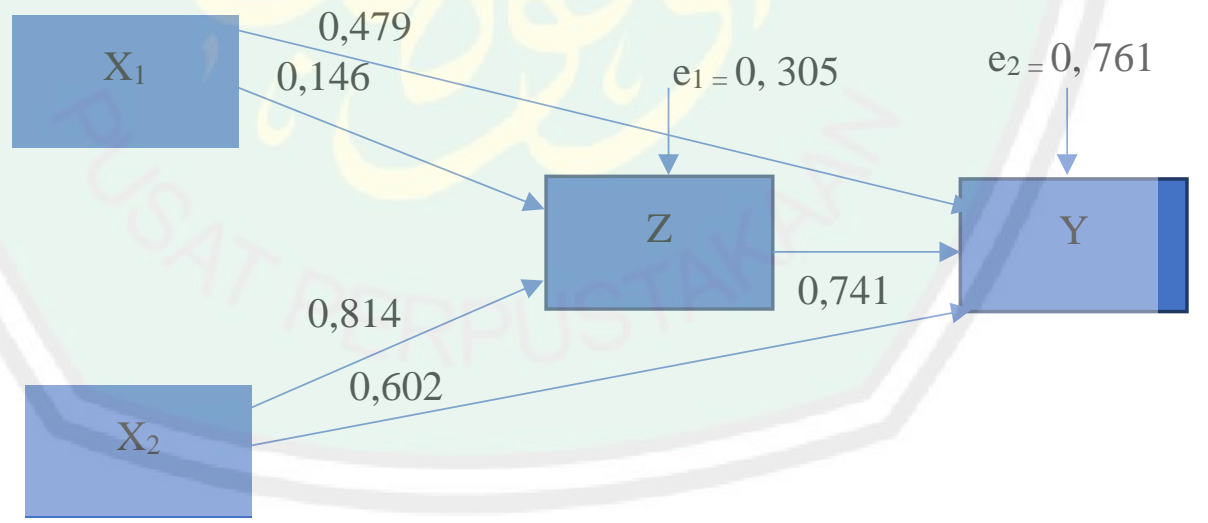

\section{Pengujian Pengaruh Tidak Langsung Antar Variabel}

Pengujian pengaruh tidak langsung pada penelitian ini menggunakan perkalian antara nilai beta $\mathrm{X}_{1}$ terhadap $\mathrm{Z}$ dengan nilai beta $\mathrm{Z}$ terhadap $\mathrm{Y}$, maka besar pengaruh tidak langsung variabel lingkungan kerja terhadap kinerja 
guru melalui kepuasan kerja yaitu: $0,146 \times 0,741=0,108$. Maka pengaruh total yang diberikan lingkungan kerja terhadap kinerja guru adalah: nilai pengaruh tidak langsung ditambah dengan nilai pengaruh langsung: $0,108+$ $0,479=0,587$. Jadi nilai pengaruh total variabel lingkungan kerja terhadap kinerja sebesar 0,587. karena hasil pengaruh tidak langsung lebih besar dari pada pengaruh langsung maka kepuasan kerja bisa menjadi full mediasi lingkungan kerja terhadap kinerja guru.

Sedangkan untuk pengaruh tidak langsung untuk variabel motivasi kerja juga menggunakan perkalian antara nilai beta $\mathrm{X}_{2}$ terhadap $\mathrm{Z}$ dengan nilai beta $\mathrm{Z}$ terhadap $\mathrm{Y}$, maka besar pengaruh tidak langsung variabel motivasi kerja terhadap kinerja guru melalui kepuasan kerja yaitu: 0, $814 \mathrm{x}$ $0,741=0,603$. Maka pengaruh total yang diberikan motivasi kerja terhadap kinerja guru adalah: nilai pengaruh tidak langsung ditambah dengan nilai pengaruh langsung: $0,603+0,602=1,205$. Jadi nilai pengaruh total variabel motivasi kerja terhadap kinerja sebesar 1,205. karena hasil pengaruh tidak langsung lebih besar dari pada pengaruh langsung maka kepuasan kerja bisa menjadi full mediasi motivasi kerja terhadap kinerja guru. 


\section{BAB V}

\section{PEMBAHASAN}

\section{A. Pengaruh Lingkungan Kerja Terhadap Kepuasan Kerja}

Sesuai dengan ulasan hasil analisis di atas diperoleh hasil bahwa lingkungan kerja berpengaruh terhadap kepuasan kerja. Jadi bisa disimulkan bahwa semakin baik lingkungan kerja maka akan semakin tinggi kepuasan kerja guru.

Penelitian ini sejalan dengan penelitian yang telah dilakukan Fajar Mayasari yang mengatakan ada pengaruh yang signifikan dari lingkungan kerja terhadap kepuasan kerja ${ }^{89}$. Hal ini juga diperkuat oleh penelitian yang dilakukan oleh Dewi Purnama Sari yang menjelaskan bahwa lingkungan kerja mempunyai penngaruh yang positif terhadap terbentuknya kepuasan kerja. ${ }^{90}$

Lingkungan kerja adalah tempat guru berinteraksi dan beraktivitas dalam kesehariannya, oleh karena itu guru tidak bisa lepas dari pengaruh erat lingkungan sekitar. kondisi lingkungan dikatakan baik apabila manusia dapat melaksanakan kegiatan secara optimal, sehat, aman, dan nyaman. Kesesuaian lingkungan kerja dapat memberikan kepuasan kerja tersendiri bagi guru. Lingkungan Kerja dapat mempengaruhi kepuasan kerja hal ini dikarenakan kepuasan kerja adalah faktor eksternal yang sangat dibutuhkan agar

\footnotetext{
${ }^{89}$ Fajar Maya Sari, Pengaruh Kompetensi Dan Lingkungan Kerja Terhadap Kepuasan Kerja Dan Kinerja Guru Di SD Negeri Kecamatan Gondang Mojokerto. DIE, Jurnal Ilmu Ekonomi \& Manajemen April 2013, Vol. 9 No.2. Hlm. 150

90 Dewi Purnama Sari, Pengaruh Lingkungan Kerja Dan Disiplin Kerja Terhadap Kepuasan Kerja Guru Sekolah Menengah Kejuruan (Smk) Swasta Sekecamatan Pondok Aren. jurnal saintika unpam vol. 1, no. 1, juli 2018, ISSN 2621-7856
} 
kenyamanan guru dalam mengajar bisa tercapai, baik lingkungan fisik maupun lingkungan nonfisik. Lingkungan kerja fisik sangat dibutuhkan oleh guru untuk memperoleh kenyamanan dalam segala proses yang ada disekolah yang nantinya akan berdampak pada proses belajar mengajar yang baik. Sedangkan lingkungan non fisik lebih ke arah hubungan sosial yang ada di sekolah, yakni hubungan antara atasan dan guru, antar guru dan juga antar guru dnan karyawan.

Faktor ini menjadi sangat penting karena berpengaruh pada perasaan dan kondisi batin yang dirasakan oleh para guru dalam kesehariannya di sekolah. Jika faktor non fisik ini bisa tercapai maka akan tercapai keharmonisan dalam lingkungan sekolah yang akan berdampak pada meningkatnya rasa puas dan nyaman dari guru akan pekerjaannya.

Menurut Handoko, Kepuasan kerja adalah cerminan dari perasaan individu pada pekerjaannya, yang bisa dilihat dari sikap positif individu tersebut pada pekerjaan dan segala sesuatu yang ada di lngkungannya. ${ }^{91}$ S. Schulze, mengatakan bahwa kepuasan kerja juga dipengaruhi oleh faktor demografi. salah satu diantaranya lingkungan sekitar , etnik grup dan gender. ${ }^{92}$ Lingkungan kerja yang baik dapat menciptakan kenyamanan dan menjadi fajtor pendukung terciptanya rasa semangat dan meningkatnya kinerja guru.

\footnotetext{
91 Handoko, Hani. 2000. Manajemen Personalia dan Sumber Daya Manusia, edisi kedua.Yogyakarta : BPFE-Yogyakarta.

92 S. Schulze, (2006), Journal,.Departemen of Further Teacher Education School of Education, University of South Africa Pretoria.Factors Influencing the Job Satisfaction of Academics in Higher Education.Unisa Press ISSN 1011-3487
} 


\section{B. Pengaruh Motivasi Kerja Terhadap Kepuasan Kerja Guru}

Sesuai dengan ulasan hasil analisis di atas diperoleh hasil bahwa motivasi kerja berpengaruh terhadap kepuasan kerja guru, dan ini sesuai dengan teoriteori yang telah dijelaskan sebelumnya. Semakin tinggi Motivasi kerja guru maka akan semakin tinggi kepuasan kerja guru Madrasah Aliyah di Pulau Bawean.

Hal ini sejalan dengan penelitian yang dilakukan oleh Sorni Paskah Deli yang menjelaskan bahwa, kepuasan kerja mempunyai pengaruh positif dalam pembentukan kinerja yang baik, baik secara parsial maupn secara jamak. ${ }^{93} \mathrm{Ni}$ made Nurcahyani juga mengatakan dalam penelitiannya bahwa ada pengaruh yang positif dan signfikan antara motivasi kerja terhada kinerja guru. ${ }^{94}$

Motivasi diberikan untuk menjaga semangat kerja yang diharapkan akan berdampak pada terlaksanakan pekerjaan secara optimal. Motivasi diberikan agar pegawai terdorong untuk melakukan tugasnya dengan rasa tanpa adanya paksaan, sehingga berdampak pada pencapaian kinerja yang tinggi. ${ }^{95}$

Motivasi kerja bagi guru sangat mempengaruhi keinginan guru dalam melakukan pekerjaannya di sekolah. Motivasi ini bisa berasal dari dalam diri guru sendiri maupun dari luar. Kesungguhan dan kedisipinan guru dalam mengajar akan membuat guru memberikan yang terbaik dalam melaksanakan tugas dan guru akan terdorong untuk menjadi lebih baik lagi dan bekerja secara

\footnotetext{
${ }^{93}$ Sorni Paskah Deli, Hubungan Kepemimpinan dan Motivasi Kerja Dengan Kepuasan Kerja, Badan Penelitian dan Pengembangan ,Kementerian Dalam Negeri.

${ }^{94}$ Ini Made Nurcahyani dan I Gusti Ayu Dewi Adnyani, Pengaruh Kompensasi Dan Motivasi Terhadap Kinerja Karyawan Dengan Kepuasan Kerja Sebagai Variabel Intervening. E Jurnal Manajemen Unud, 5, 2016. ISSN 2302-8912

95 Engkoswara, Aan Komariah, Administrasi Pendidikan, (Alfabeta: Bandung, 2012),Hlm 201
} 
maksimal yang nantinya akan mendorong pada upaya pemenuhan kepuasan dan keinginan. Jika guru merasa puasa maka guru akan bekerja dengan semangat.

Kreitner dan Kinicki dalam Wibowo, memfokus pada mengidentifikasi faktor internal seperti naluri, kebutuhan, kepuasan dan karakteristik kerja yang memberikan daya pada motivasi pekerja. dari penjelasan di atas dapat dikatakan bahwa kepuasan kerja dipengaruhi oleh motivasi kerja. ${ }^{96}$

\section{Pengaruh Lingkungan Kerja Terhadap Kinerja Guru}

Hasil analisis di atas diperoleh hasil bahwa Lingkungan kerja berpengaruh terhadap kinerja guru, dan ini sesuai dengan teori-teori yang telah dijelaskan sebelumnya. Semakin baik Lingkungan kerja guru maka akan semakin tinggi kinerja guru Madrasah Aliyah di Pulau Bawean.

Hal ini sesuai dengan penilitian Anita Anggreini Batubara yang mengatakan bahwa antara lingkungan kerja dengan kinerja guru mempunyai pengaruh antar variabel, da pengaruh kedua variabel ini merupakan pengaruh yang kuat. ${ }^{97}$ Emmanuel Majekodunmi Ajala, juga menjelaskan bahwa lingkungan kerja mempunyai pengaruh signifikan terhadap kinerja guru. ${ }^{98}$ Ahmad Zarkasyi dalam penelitiannya juga menjelaskan bahwa Lingkungan kerja mempunyai pengaruh terhadap kualitas kerja guru, semakin baik kualitas

\footnotetext{
${ }^{96}$ Wibowo. Manajemen Kinerja. (Jakarta: Rajawali Pers.2013),hlm 111

${ }^{97}$ Anita Anggreini Batubara ,pengaruh lingkungan kerja, kompensasi dan komitmen terhadap kinerja guru MAN di medan (Malang: PPS Universitas Islam Negeri Malang 2016): Tesis tidak diterbitkan

98 Emmanuel Majekodunmi Ajala, The Infuence of workplace environment on workers welfare, performance and proctivity, the african Symposium: An online journal of the african educational Research network, university of ibadan. Volume 12, No. 1, June 2012
} 
lingkungan kerja maka akan semakin baik pula kinerja guru. ${ }^{99}$ Hal ini juga diperkuat oleh penelitian yang dilakukan oleh aung wahyudi dkk, yang mengatakan bahwa lingkungan kerja mempunyai pengaruh yang signifikan terhadap kinerja. 100

Lingkungan kerja adalah tempat beraktivitas dan berinteraksi guru setiap harinya. Lingkungan kerja yang baik dapat mendorong guru untuk bekerja secara optimal. Lingkungan kerja dapat mempengaruhi kinerja guru. Jika lingkungan kerja baik maka kinerja guru juga akan meningkat.

Lingkungan kerja juga berhubungan dengan komunikasi antara bawahan dan atasannya. Lingkungan kerja juga merupakan kehidupan sosial, psikologi, dan fisik dalam lembaga. Lingkungan kerja sebagai tempat bekerja yang merupakan segala sesuatu yang berada di sekitar para pekerja/ karyawan/ pegawai pada saat mereka bekerja tentulah sangat berpengaruh kepada kinerja mereka Lingkungan kerja, baik yang bersifat fisik seperti lingkungan yang langsung kepada guru (kursi, meja, dan sebagainya) dan lingkungan perantara (temperatur, sirkulasi udara, kebisingan, tata warna, bau, keamanan, dan sebagainya), maupun lingkungan yang non fisik atau semua keadaan yang terjadi yang berkaitan dengan hubungan kerja, baik hubungan dengan atasan maupun hubungan dengan sesama rekan kerja atau hubungan kerja dengan bawahan, sangat menentukan kinerja

\footnotetext{
${ }^{99}$ Ahmad Zarkasyi, Pengaruh Lingkungan Kerja Dan Kompetensi Sosial Terhadap Kinerja Kepala Sekolah Tingkat Menengah Atas Se-Kota Lumajang.

100 AgungWahyu dkk, Pengaruh Lingkungan kerja, Kompensasi danKomitmen organisasi terhadap Kepuasan karyawan Di Rs "X".'Kerja Jurnal Riset Manajemen Sains Indonesia (JRMSI) | Vol. 4, No. 1, 2013
} 
Hal ini sesuai dengan penelitian Barry Render \& Jay Heizer menjelaskan bahwa, lingkungan kerja merupakan lingkungan fisik yang berhubungan dengan tempat karyawan bekerja dan dapat mempengaruhi kinerja, keamanan dan mutu kehidupan kerja mereka. Lingkungan kerja yang baik akan memberikan rasa aman dan membuat karyawan bekerja secara optimal yang akan berdampak pada kinerja pegawai akan tinggi. ${ }^{101}$

\section{Pengaruh Motivasi Kerja Terhadap Kinerja Guru}

Sesuai dengan ulasan hasil analisis di bab iv diperoleh hasil bahwa Motivasi kerja berpengaruh terhadap kinerja guru, dan ini sesuai dengan teoriteori yang telah dijelaskan sebelumnya. Semakin tinggi motivasi kerja guru maka akan semakin tinggi kinerja guru Madrasah Aliyah di Pulau Bawean.

Penelitian ini sejalan dengan penelitian yang dialakukan oleh Fayruzah Elfaradis yang mengatakan bahwa Motivasi kerja berpengaruh terhadap kinerja guru, hal ini juga di perkuat oleh penelitian yang dilakukan Kristian yang mengatakan bahwa motivasi mempunyai pengaruh yang kuat terhadap sikap mengajar dosen. ${ }^{102}$

Rokhila dan Susetyo dalam penelitiannya juga menjelaskan bahwa antara Motivasi kerja dan kinerja mempunyai hubungan yang signifikan. ${ }^{103}$ Ni Made Nur cahyani menjelaskan bahwa motivasi kerja mempunyai pengaruh yang

\footnotetext{
${ }^{101}$ Barry, Render dan Jay Heizer. Prinsip-prinsip Manajemen Operasi :Operations Management. (Jakarta : Salemba Empat. 2001.) hlm 239

${ }^{102}$ Fayruzah El-Faradis, Pengaruh Kompetensi Manajerial Kepala Sekolah dan Motivasi Kerja terhadap Kinerja Guru di Tarbiyatul Muallimin Al-Islamiyah (TMI) Putri Al-Amien Prenduan Sumenep Madura. (Malang: PPS Universitas Islam Negeri Malang 2016): Tesis tidak diterbitkan ${ }^{103}$ Rokhilah dan Susetyo Darmanto, pengaruh kompetensi, motivasi dan lingkungan kerja terhadap kinerja penyuluh lapangan program keluarga berencana (plkb) di kabupaten pemalang, Media ekonomi dan Manajemen, Vol. 29 No. 1 Januari 2014.
} 
signifikan terhadap kinerja guru, semakin tinggi kepuasan kerja maka akan mendorong kaaryawan untuk meningkatan prestasi yang akan berdampak pada peningkatan kinerja. ${ }^{104}$

Setiap orang mempunyai faktor internal tersendiri yang bisa mempengaruhi perilakunya sehari-hari. salah satu faktor internal tersebut adalah motivasi yang mampu menggerakkan seseorang untuk melakukan pekerjaannya.

Motivasi kerja sendiri bisa berasal dari dalam diri maupun dari luar. Motivasi disini tidak hanya mengenai gaji maupun faktor ekonomi saja, namun juga bisa berasal dari faktor psikologi guru itu sendiri, Motivasi ini bisa berupa kebanggaan dan kecintaan guru dalam melakukan pekerjaan.

Menurut Eko Supraptono, beberapa hal yang bisa mempengaruhi kinerja guru diantaranya: kepemimpinan kepala sekolah, budaya sekolah,motivasi kerja guru, dan komitmen guru. ${ }^{105}$

\section{E. Pengaruh Kepuasan Kerja Terhadap Kinerja Guru}

Hasil analisis di atas diperoleh hasil bahwa Kepuasan kerja berpengaruh terhadap kinerja guru, dan ini sesuai dengan teori-teori yang telah dijelaskan sebelumnya. Semakin tinggi motivasi kerja guru maka akan semakin tinggi kinerja guru Madrasah Aliyah di Pulau Bawean.

\footnotetext{
104 I Gusti Ayu Dewi Adnyani, Pengaruh Kompensasi Dan Motivasi Terhadap Kinerja Karyawan Dengan Kepuasan Kerja Sebagai Variabel Intervening. E Jurnal Manajemen Unud, 5, 2016. ISSN 2302-8912

105 Eko Supraptono, (2008), Analisis Pengaruh Factor Kepemimpinan Partisipatif Kepala Sekolah, Budaya Sekolah, Manajemen Perubahan, Motivasi Kerja Guru, dan Komitmen Guru Terhadap Kinerja Guru dan Mutu Pembelajaran di SMA NegeriKabupaten Lebak, Banten, Disertasi Program Doktor Ilmu Manajemen Pascasarjana Universitas Pasundan Bandung.
} 
Hal ini sejalan dengan penelitian yang dilakukan oleh penelitian yang dilakukan oleh Fajar Mayasari, yanng mengatakan bahwa, kepuasan kerja mempunyai pengaruh yang signifikan terhadap kinerja guru, hal ini juga diperkuat oleh peilitian yang dilakukan oleh Koesmono yang mengatakan hal yang serupa. ${ }^{106}$ Ferdy Ardiansyah dan Sylvia Diana Purba dalam penelitiannya juga menjelaskan bahwa antara kepuasan kerja dan kinerja saling berengaruh secara signifikan. ${ }^{107}$

Kepuasan kerja merupakan perasaan nyaman dan senang yang dirasakan oleh guru yang ditunjukkan dengan perilaku positif (kinerja meningkat) karena adanya pemenuhan kebutuhan. Kepuasan kerja mempunyai perananan penting dalam peningkatan kinerja guru karena kepuasaan kerja akan mendorong guru untuk mencapai keamtangan psikologis dan juga aktualisasi guru yang akan berdampak denngan rajinnya guru dan tingkat kehadiran yang tinggi di sekolah dan nantinya akan menciptakan prestasi kerja.

Sebagaimana menurut Robbins, pekerja yang tercapai kepuasan kerjanya akan merasa bahagia dan akan menjadi pekerja yang produktif. ${ }^{108}$ Sedangkan Rivai dan Fawzi, menjelaskan bahwa kinerja selalu berhubungan dengan kepuasan kerja dan tingkat imbalan dan sifat-sifat individu. Kepuasan kerja merupakan luapan perasaan seorang guru terhadap pekerjaannya tentang sejauh

\footnotetext{
${ }^{106}$ Fajar Maya Sari, Pengaruh Kompetensi Dan Lingkungan Kerja Terhadap Kepuasan Kerja Dan Kinerja Guru Di SD Negeri Kecamatan Gondang Mojokerto. DIE, Jurnal Ilmu Ekonomi \& Manajemen April 2013, Vol. 9 No.2.

${ }^{107}$ Ferdy Ardiansyah dan Sylvia Diana Purba, Pengaruh kepuasan Kerja ,Lingkungan Kerja Terhadap Kinerja Guru Dengan Motivasi Karir Sebagai Variabel Moderasi Dan kepuasan Karir sebagai Variabel Mediasi Pada YP IPPI. DeReMa Jurnal Manajemen Mei 2015, Vol.10 No.. 10 108 Robbins Stephen P., Judge Timothy AOrganization Behavior, terjemahan, (Salemba Empat, Jakarta.2009), hlm 237
} 
mana pekerjaannya mampu memuaskan kebutuhannya. ${ }^{109}$ Guru yang kepuasan kerjanya terpenuhi akan berdampak pada meningkatnya kinerja.

\section{F. Pengaruh Tidak Langsung Lingkungan Kerja Terhadap Kinerja Guru}

\section{Melalui Kepuasan Kerja}

Berdasarkan hasil analisa Pengujian pengaruh tidak langsung pada penelitian ini, menjelaskan bahwa lingkungan kerja bisa mempengaruhi kinerja, apabila lingkungan kerja mempunyai kualitas yang baik, nyaman dan menyenangkan tentua akan menambah rasa puas pada diri seorang guru, dan hal ini akan memicu semangat guru dalam mengajar yang anntinya akan mempunyai dampak pada peningkatan kinerja guru.

Dari hasil analisa tersebut bisa dikatakan ada hubungan tidak langsung antara variabel lingkungan kerja dengan kinerja guru melalui kepuasan kerja, namun dengan angka yang relatif kecil bila dibandingkan dengan hubungan langsung antara kedua variabel tersebut.

Lingkungan kerja yang baik akan memberikan kenyamanan terhadap guru dalam melaksanakan proses belajar mengajar, dan akan berdampak pada terpenuhinya kepuasaan kerja guru, seperti yang di jelaskan, S. Schulze, bahwa kepuasan kerja juga dipengaruhi oleh lingkungan sekitar. ${ }^{110}$ Kepuasan kerja mempunyai perananan penting dalam peningkatan kinerja guru karena

\footnotetext{
${ }^{109}$ Veithzal Rivai, Ahmad Fawzi Moh Basri, Performance Appraisal, (PT. Raja Grafindo Persada Jakarta 2013) hlm 16-17

${ }^{110}$ S. Schulze, (2006), Journal,.Departemen of Further Teacher Education School of Education, University of South Africa Pretoria.Factors Influencing the Job Satisfaction of Academics in Higher Education.Unisa Press ISSN 1011-3487
} 
kepuasaan kerja akan mendorong guru untuk mencapai kematangan psikologis dan juga aktualisasi guru yang akan berdampak dengan rajinnya guru dan tingkat kehadiran yang tinggi di sekolah dan nantinya akan meningkatkan kinerja guru.

Hal ini sesuai dengan penelitian terdahulu yang telah dilakukan oleh Hesti Ruscahyono $^{111}$ yang menyebutkan hasil yang sama. Namun jika kepuasan kerja terpenuhi maka akan bertambah dengan meningkatnya kinerja guru hal ini terlihat dari besar pengaruh total yang telah diberikan oleh lingkungan kerja terhadap kinerja guru. Hal serupa juga disebutkan oleh Bayu Kurniawan dalam penelitiannya bahwa kepuasan kerja sebagai variabel yang memoderasi menguatkan pengaruh lingkungan kerja terhadap kinerja guru SMK N 1 Pati. ${ }^{112}$

G. Pengaruh Tidak Langsung Motivasi Kerja Terhadap Kinerja Guru Melalui Kepuasan Kerja

Berdasarkan hasil analisa Pengujian pengaruh tidak langsung pada penelitian ini, menjelaskan bahwa terdapat pengaruh tidak langsung motivasi kerja terhadap kinerja guru melalui kepuasan kerja. Dorongan yang berasal dalam diri guru sendiri mempunyai pengaruh yang besar dalam keberhasilan pembelajaran, guru yang mempunyai motivasi yang baik akan mendorong siswa untuk aktif dan ikut dalam proses belajar mengajar. Hal ini tentu akan mempengaruhi rasa puas pada diri guru sendiri akan pekerjaannya, dengan berjalannya proses belajar mengajar yang baik tentu akan berdampak pada peningkatan kinerja guru itu sendiri.

\footnotetext{
${ }^{111}$ Hesti Ruscahyono, pengaruh locus of control lingkungan kerja terhadap kinerja guru smkn 4 klaten dengan variabel kepuasan kerja sebagai intervening, aktual edisi februari 2014. Vol.1 no. 2 ${ }^{112}$ Bayu Kurniawan, kepuasan kerja memoderasi pengaruh lingkungan kerja dan kepemimpinan kepala sekolah terhadap kinerja guru smk negeri 1 pati, Bingkai Manajemen 2017
} 
Motivasi dapat diartikan sebagai keadaan atau tindakan yang mendorong guru untuk melakukan tugasnya semaksimal mungkin. Guru yang memiliki motivasi yang rendah akan cenderung untuk menampilkan perasaan tidak nyaman dan tidak senang terhadap pekerjaannya, tentunya akan berdampak pada kinerja guru yang rendah.

Motivasi setiap guru dalam melaksanakan tugasnya berbeda-beda harus dipahami dari segi kebutuhan manusia karena pada hakekatnya setiap guru memiliki motivasi yang berbeda-beda dalam bekerja. Pimpinan memiliki kewajiban untuk selalu memotivasi guru agar meningkatkan kinerjanya.

Motivasi kerja bagi guru sangat mempengaruhi keinginan guru dalam melakukan pekerjaannya di sekolah. Motivasi ini bisa berasal dari dalam diri guru sendiri maupun dari luar. Kesungguhan dan kedisipinan guru dalam mengajar akan membuat guru memberikan yang terbaik dalam melaksanakan tugas dan guru akan terdorong untuk menjadi lebih baik lagi dan bekerja secara maksimal yang nantinya akan mendorong pada upaya pemenuhan kepuasan dan keinginan. Jika guru merasa puas maka guru akan bekerja dengan semangat, dan akan berdampak pada peningkatan kinerja guru.

Hal ini sesuai dengan teori-teori yang telah dijelaskan diawal yang menyebutkan hasil yang sama dan diperkuat oleh penelitian yang dilakukan M.

Kharis Fadlillah yang mengatakan bahwa motivasi kerja mempunyai pengaruh tidak langsung terhadap kinerja guru melalu kepuasan kerja. ${ }^{113}$ Dan diperkuat

\footnotetext{
${ }^{113}$ M. Kharis Fadillah, Pengaruh Keefektifan kepemimpinan, Budaya Organisasi, Motivasi Kerja, Komitmen Organisasi Dan Kepuasan Kerja Terhadap Kinerja Guru Madrasah Aliyah Negeri Di Malang Raya. (Malang: PPS Universitas Islam Negeri Malang 2016): Disertasi tidak diterbitkan
} 
oleh penelitian Ni Made Nurcahyani yang menjelaskan bahwa motivasi berpengaruh positif dan signifikan terhadap kepuasan kerja, motivasi berpengaruh positif dan signifikan terhadap kinerja karyawan, kepuasan kerja berpengaruh positif dan signifikan terhadap kinerja karyawan dan kepuasan kerja memediasi pengaruh motivasi terhadap kinerja karyawan. ${ }^{114}$

\footnotetext{
${ }^{114}$ I Gusti Ayu Dewi Adnyani, Pengaruh Kompensasi Dan Motivasi Terhadap Kinerja Karyawan Dengan Kepuasan Kerja Sebagai Variabel Intervening. E Jurnal Manajemen Unud, 5, 2016. ISSN 2302-8912
} 


\section{BAB VI \\ PENUTUP}

\section{A. Kesimpulan}

Berdasarkan hasil analisis dan pembahasan hasil penelitian, maka dapat disimpulkan sebagai berikut :

1. Ada pengaruh positif dan signifikan antara lingkungan kerja dengan kepuasan kerja guru madrasah aliyah di pulau Bawean. Semakin baik lingkungan kerja maka akan semakin tinggi pula kepuasan kerja guru madrasah aliyah di pulau Bawean.

2. Ada pengaruh positif dan signifikan antara motivasi kerja dengan kepuasan kerja guru madrasah aliyah di pulau Bawean. Semakin tinggi motivasi kerja guru maka akan semakin tinggi pula kepuasan kerja guru madrasah aliyah di pulau Bawean.

3. Ada pengaruh positif dan signifikan antara lingkungan kerja dengan kinerja guru madrasah aliyah di pulau Bawean. Semakin baik lingkungan kerja maka akan semakin tinggi pula kinerja guru madrasah aliyah di pulau Bawean.

4. ada pengaruh positif dan signifikan antara motivasi kerja dengan kinerja guru madrasah aliyah di pulau Bawean. Semakin tinggi motivasi kerja guru maka akan semakin tinggi pula kinerja guru madrasah aliyah di pulau Bawean.

5. Ada pengaruh positif dan signifikan antara kepuasan kerja guru dengan kinerja guru madrasah aliyah di pulau bawean. Semakin tinggi kepuasan kerja guru maka akan semakin tinggi pula kinerja guru madrasah aliyah di Pulau Bawean. 
6. Ada pengaruh tidak langsung antara lingkungan kerja dengan kinerja guru melalui kepuasan kerja guru madrasah aliyah di pulau Bawean.

7. ada pengaruh tidak langsung antara lingkungan kerja dengan kinerja guru melalui kepuasan kerja guru madrasah aliyah di pulau Bawean.

\section{B. Implikasi Teoritis dan Praktik}

Berdasarkan analisis data dan pembahasan, maka dapat dikemukakan implikasi teoritis, hasil penelitian yang mengungkapkan pengaruh lingkungan kerja, motivasi kerja terhadap kepuasan kerja dan dampaknya pada kinerja guru madrasah aliyah di pulau Bawean. Dari dua variabel bebas, satu variabel intervening dan satu variabel terikat dan tujuh hipotesis yang dikemukakan membuktikan adanya pengaruh positif dan signifikan dari semua variabel.

Karena lingkungan kerja, motivasi kerja , dan kepuasan kerja guru sangat mempengaruhi kinerja guru, maka diperlukan adanya pemberian pelayanan yang baik kepada guru. Dari berbagai teori yang melandasi penelitian ini menyatakan apabila ketiga variabel yakni variabel lingkungan kerja, motivasi kerja, dan kepuasan kerja guru terpenuhi dengan baik maka akan berdampak pada adanya kinerja guru yang baik bahkan akan terus meningkat.

Berdasarkan Hasil dari penelitian ini mempunyai beberapa implikasi praktik. Pertama, Dengan diterimanya hipotesis yang ada diharapkan lembaga lebih memperhatikan masalah lingkungan dan kepuasan kerja guru dalam rangka meningkatkan kinerja guru dan tentunya dengan dorongan motivasi baik dari lembaga maupun dari kepala madrasah. 
Kedua, dengan terciptanya lingkungan kerja yang baik, kepuasan kerja yang tinggi, motivasi kerja yang tinggi maka pencapaian kinerja guru yang baik akan tercapai. namun hal ini tidak lepas dari peranan kepala madrasah dalam memperhatikan tanggung jawabnya dan juga tanggung jawab bawahannya, dengan adanya perhatian dari kepala madrasah diharapkan kinerja guru akan terus terjaga dan meningkat. 


\section{DAFTAR PUSTAKA}

Adnyani, I Gusti Ayu Dewi .2016. Pengaruh Kompensasi Dan Motivasi Terhadap Kinerja Karyawan Dengan Kepuasan Kerja Sebagai Variabel Intervening. E Jurnal Manajemen Unud, 5, 2016. ISSN 2302-8912

Ardiansyah, Ferdy dan Sylvia Diana Purba. 2015. Pengaruh kepuasan Kerja ,Lingkungan Kerja Terhadap Kinerja Guru Dengan Motivasi Karir Sebagai Variabel Moderasi Dan kepuasan Karir sebagai Variabel Mediasi Pada YP IPPI. DeReMa Jurnal Manajemen Mei 2015, Vol.10 No. 10

As’ad, Moh. 1999. Psikologi Industri Yogyakarta: Liberty

Badan Standar Nasional Pendidikan (BSNP). 2012. pedoman pelaksanaan penilaian kinerja guru, kementerian dan kebudayaan RI

Bahler, Patricia. 2004. Alpha Teach Your Self; Management skills dalam 24 jam. Penerjemah Sugeng Haryanto dkk, Jakarta: Prenada media gruop

Barnawi \& Mohammad Arifin. 2011. Instrumen Pembinaan, Peningkatan, \& penilaian Kinerja Guru Profesional, Bandung: Alfabeta

Barnawi \& Mohammad Arifin. 2012. Kinerja guru profesional. Yogyakarta: ArRuzz media

Barry, Render dan Jay Heizer. 2001. Prinsip-prinsip Manajemen Operasi :Operations Management. Jakarta : Salemba Empat

Batubara, Anita Anggreini. 2016. pengaruh lingkungan kerja, kompensasi dan komitmen terhadap kinerja guru MAN di medan. Malang: PPS Universitas Islam Negeri Malang Tesis tidak diterbitkan

Bestiana, Rsita 2012 hubungan kepuasan kerja, motivasi dan komitmen normatif dengan kinerja guru smpn 1 rantau selatan - labuhan batu. jurnal tabularasa

Brahmasari Ida Ayu dan Agus Suprayetno,2008. Pengaruh Motivasi Kerja, Kepemimpinan dan Budaya Organisasi, Terhadap Kepuasan Kerja Karyawan serta Dampaknya pada Kinerja Perusahaan (Studi kasus pada PT. Pei Hai International Wiratama Indonesia) jurnal manajemen dan kewirausahaan, vol.10, no. 2, september 2008: 124-135

Brahmasari, Ida Ayu. 2004. pengaruh variabel budaya perusahaan terhadap komitmen karyawan dan kinerja perusahaan kelompok penerbitan Pers jawa pos , disertasi Surabaya: Universitas Airlangga Surabaya

C. Ostroff, 1992.The relationship between satisfiction, attitudes, and performance: an organizational level. analysis journal of appliyed psychology,77(6) 
D.C. Mc Clelland. 1961. The Achieving Society, New Jersey: Princeton, D Van Nostrand

Departemen Agama RI, Al-Hidayah: Al-Quran Tafsir Per kata Tajwid Kode Angka Banten:Kalim

Dessler Gary. 1997. Manajemen Sumber Daya Manusia. Jakarta: PT. Prenhallindo

Dizgah. Morad Razaiei et al, 2012, Realetionship between job satisfaction and empoyee job performance in guilan Public sector, Jurnal of Basic and Applied Scientific Research 2(2) 1735- 1741, ISSN 2090-4304

El-Faradis Fayruzah. 2016. Pengaruh Kompetensi Manajerial Kepala Sekolah dan Motivasi Kerja terhadap Kinerja Guru di Tarbiyatul Muallimin AlIslamiyah (TMI) Putri Al-Amien Prenduan Sumenep Madura. (Malang: PPS Universitas Islam Negeri Malang 2016): Tesis tidak diterbitkan

Emmanuel Majekodunmi Ajala, 2012. The Infuence of workplace environment on workers welfare, performance and proctivity, the african Symposium: An online journal of the african educational Research network, university of ibadan. Volume 12, No. 1, June 2012

Engkoswara, Aan Komariah. 2012. Administrasi Pendidikan. Alfabeta: Bandung

Fadillah M. Kharis. 2016., Pengaruh Keefektifan kepemimpinan, Budaya Organisasi, Motivasi Kerja, Komitmen Organisasi Dan Kepuasan Kerja Terhadap Kinerja Guru Madrasah Aliyah Negeri Di Malang Raya. (Malang: PPS Universitas Islam Negeri Malang 2016): Disertasi tidak diterbitkan

Firmansyah. Farid.2008. Pengaruh lingkungan kerja, kompensasi dan kepemimpinan, terhadap kepuasan kerja guru dan karyawan di SMA Wachid Hasyim Surabaya, Tadris. 94 Volume 3. Nomor 1. 2008 Hlm. 95

Galton, Maurice dan Brian Simon, 1994. Progress and Performance in The Primary Classroom, (London: Roultledge dan Kegan Paul

Gibson, James L, et. all. 1985, "Organisasi: Perilaku Struktur Proses”, Jilid 1, Edisi Kelima, , Jakarta: Erlangga

Handoko, Hani. 2000. Manajemen Personalia dan Sumber Daya Manusia, edisi kedua.Yogyakarta : BPFE-Yogyakarta.

Hasan, M. Iqbal. 2002. Metode Peneltian dan Aplikasinya Jakarta: Ghalian Indonesia,

Kasiram , Moh.. 2008. Metodelogi Penelitian Kualitatif-Kuantitatif . Malang: Uin Malang Press 
Kompas.com Oline. Rata-rata Hasil Uji Kompetensi guru Masih Rendah, (jumat, 12 Maret 2012) di akses pada tanggal 12 desember 2017. Tersedia

Kompri. 2015. Manajemen Pendidikan: Komponen-komponen elementer Kemajuan Sekolah.Yogyakarta:Ar-Ruzz Media

Kristian, Pengaruh Metode Mengajar dan Motivasi Berprestasi terhadap Perolehan Ilmu Ukur Tanah Mahasiswa FPTK IKIP. (Malang: PPs IKIP Malang, 1995), tesis tidak dipublikasikan

Kumar, Jalaja., Rao, B. D. 2007. Job Satisfaction of Teacher. New Delhi Sachin Printers.

Kurniawan, Bayu. 2017 kepuasan kerja memoderasi pengaruh lingkungan kerja dan kepemimpinan kepala sekolah terhadap kinerja guru smk negeri 1 pati, Bingkai Manajemen

Mangkunegara, Anwar Prabu. 2005. Evaluasi Kinerja. Bandung : Refika Aditama

Masrukhin dan Waridin, 2006. pengaruh motivasi kerja, kepuasan kerja, budaya organisasi dan kepemimpinan terhadap kinerja pegawa, jurnal ekonomi \& bisnis , vol 7, No.2

Moekijat. 1995. Tata Laksana Kantor. Bandung : Alumni

Moh As'ad.1995. Psikologi Industri. Liberty : Yogyakarta

Muhaimin, , 2003. Wacana Pengembangan Pendidikan Islam, Yogyakarta: Pustaka Pelajar

Muwahid Shulhan, Gaya Kepemimpinan Kepala Madrasah Dalam Meningkatkan Kinerja Guru, (Disertasi UIN MALANG.2012

Ni Made Nurcahyani dan I Gusti Ayu Dewi Adnyani, Pengaruh Kompensasi Dan Motivasi Terhadap Kinerja Karyawan Dengan Kepuasan Kerja Sebagai Variabel Intervening. E Jurnal Manajemen Unud, 5, 2016. ISSN 2302-8912

Nisfiannoor, Muhammad. 2009. Pendekatan Statistika Modern Untuk Ilmu Sosial .Jakarta: Salemba Humanika

Nitiseminto, S. Alex. 1992. Manajemen Personalia. Jakarta : Ghalia Indonesia

Nitisemito, Alex S.2002. Manajemen Personalia, Jakarta: Ghalaia Indonesia

Pandji. Anoraga, 1998. Psikologi Kerja. Jakarta.: Rineka Cipta 
Prasetya, Agni, Pengaruh Lingkungan Kerja dan kepuasan kerja terhadap kinerja guru pada SMP Pasundan 6 Bandung dan SMK Pasundan 3 Bandung. Universitas Komputer Indonesia

Riduwan, skala pengukuran variabel-variabel penelitian (Bandung: Alfabeta, 2008

Robbins Stephen P., Judge Timothy A.2009. Organization Behavior, terjemahan Jakarta :Salemba Empat

Robbins, P. Stephen, 2001, "Perilaku Organisasi: Konsep, Kontroversi, Aplikasi”, Jilid 1, Edisi Kedelapan, Jakarta, :PT Prenhallindo

Rokhilah dan Susetyo Darmanto, 2014. pengaruh kompetensi, motivasi dan lingkungan kerja terhadap kinerja penyuluh lapangan program keluarga berencana ( $\mathrm{plkb}$ ) di kabupaten pemalang, Media ekonomi dan Manajemen, Vol. 29 No. 1 Januari 2014.

Ruscahyono, Hesthi. 2014. pengaruh locus of control dan lingkungan kerja terhadap kinerja guru smkn 4 klaten dengan kepuasan kerja sebagai intervening, Aktual edisi Pebruari 2014. Vol.1. No.2

S. Schulze, (2006), Journal,.Departemen of Further Teacher Education School of Education, University of South Africa Pretoria.Factors Influencing the Job Satisfaction of Academics in Higher Education.Unisa Press ISSN 10113487

Sari, Dewi Purnama.2018. Pengaruh Lingkungan Kerja Dan Disiplin Kerja Terhadap Kepuasan Kerja Guru Sekolah Menengah Kejuruan (Smk) Swasta Sekecamatan Pondok Aren. jurnal saintika unpam vol. 1, no. 1, juli 2018, ISSN 2621-7856

Sari, Fajar Maya,2013. Pengaruh Kompetensi Dan Lingkungan Kerja Terhadap Kepuasan Kerja Dan Kinerja Guru Di SD Negeri Kecamatan Gondang Mojokerto. DIE, Jurnal Ilmu Ekonomi \& Manajemen April 2013, Vol. 9 No.2

Sedarmayanti, 2001. Sumberdaya Manusia dan Produktivitas kerja. Jakarta: Ilham Jaya

Siagian, Sondang P. 2002, Kiat Meningkatkan Produktivitas Kerja, Jakarta: Rineka Jaya

Siregar, Edi. 2011. kinerja individual dan sistem kompensasi finansial terhadap kepuasan kerja, Jurnal Pendidikan Penabur - No.16/Tahun ke-10/Juni 2011

Sorni Paskah Deli, Hubungan Kepemimpinan dan Motivasi Kerja Dengan Kepuasan Kerja, Badan Penelitian dan Pengembangan ,Kementerian Dalam Negeri. 
Sudarmanto, R. Gunawan, 2008, Analisis Regresi Linier Ganda dengan SPSS. Yogyakarta: Graha Ilmu

Sudijono, Anas. 2003.pengantar statistik Pendidikan.Jakarta : Raja Grafindo Persada

Suharsimi Arikunto, 2006. Prosedur penelitian: Suatu Pendekatan Praktek . Jakarta: Rineka cipta

Supraptono, Eko. 2008. Analisis Pengaruh Factor Kepemimpinan Partisipatif Kepala Sekolah, Budaya Sekolah, Manajemen Perubahan, Motivasi Kerja Guru, dan Komitmen Guru Terhadap Kinerja Guru dan Mutu Pembelajaran di SMA NegeriKabupaten Lebak, Banten, Disertasi Program Doktor Ilmu Manajemen Pascasarjana Universitas Pasundan Bandung.

Suprihanto, John, 2003, Perilaku Organisasional,Yogyakarta: Sekolah Tinggi Ilmu Ekonomi YKPN

Surya, M. 2004. Psikologi Pembelajaran dan Pengajaran. Bandung, Pustaka Bani Quraisy

Sutrisno, Edy.2009, “Manajemen Sumber Daya Manusia”, Jakarta: Kencana,

Sutrisno.2008. Manajemen Sumber Daya Manusia.Jakarta: Kencana Prenata Media Group

The Liang Gie.1992. Efisiensi Kerja Bagi Pembangunan Negara. Jakarta :Erlangga.

The United Nationals educational, Scientific and curtural organization, education development indeks, (UNESCO, 2013)

Undang-undang Tentang Guru dan Dosen (Undang-Undang Republik Indonesia No. 14 Tahun 2005 serta UU No.20 Tahun 2003 Tentang SISDIKNAS), Bandung: Penerbit Citra Umbara, 2006

Veithzal Rivai, Ahmad Fawzi Moh Basri, 2013. Performance Appraisal, PT. Raja Grafindo Persada Jakarta

Wahyu, Agung dkk. 2013. Pengaruh Lingkungan kerja, Kompensasi danKomitmen organisasi terhadap Kepuasan karyawan Di Rs "X".'Kerja Jurnal Riset Manajemen Sains Indonesia (JRMSI)| Vol. 4, No. 1

Wibowo.2013. Manajemen Kinerja. Jakarta: Rajawali Pers

Zain Riduan, 2017. pengaruh kompensasi dan kepuasan kerja terhadap kinerja dosen di fakultas ilmu tarbiyah dan keguruan uin sunan kalijaga 
yogyakarta. Manageria: Jurnal Manajemen Pendidikan Islam Volume 2, Nomor 1, Mei 2017/1438

Zarkasy, Ahmad .2013. Pengaruh Lingkungan Kerja Dan Kompetensi Sosial Terhadap Kinerja Kepala Sekolah Tingkat Menengah Atas Se-Kota Lumajang. Tesis. Malang: Program Pasca Sarjana Manajemen Pendidikan Islam, Universitas Islam Negeri Maulana Maling Ibrahim. 


\section{Lampiran 1 Angket Penelitian}

\section{Pengantar Instrumen Penelitian}

Kepada

Yth: Bapak /Ibu guru di tempat..

Assalamu'alaikum Wr. Wb.

Bersama ini kami sampaikan bahwa dalam rangka penyelesaian penyusunan Tesis dengan judul : "Analisis Pengaruh Lingkungan kerja Dan Motivasi Kerja Terhadap Kepuasan Kerja Guru Dan Dampaknya Pada Kinerja Guru" pada Program Studi Manajemen Pendidikan Islam Sekolah Pascasarjana Universitas Islam Negeri Maulana Malik Ibrahim Malang, peneliti bermaksud mengumpulkan data dari bapak / ibu sekalian. Untuk memperlancar maksud tersebut, dengan ini disampaikan instrumen penelitian dengan harapan dapat meluangkan sebagian waktunya guna menjawab angket yang kami ajukan. Besar harapan kami kiranya Bapak/ Ibu bersedia mengisi kuesioner ini dengan sejujur-jujurnya dan tanpa paksaan dari pihak manapun.

Atas perhatian dan kesediaannya, kami ucapkan terima kasih. Wassalamu'alaikum Wr. Wb. 


\section{PANDUAN PENGISIAN ANGKET}

1. Jawablah setiap pertanyaan ini sesuai dengan pendapat Bapak/ Ibu/Saudara sejujur-jujurnya dan perlu diketahui bahwa jawaban dari kuesioner ini tidak berhubungan dengan benar atau salah.

2. Bapak/ibu guru diminta untuk memilih salah satu pilihan jawaban dengan cara memberi tanda $(\sqrt{ })$ pada jawaban di dalam kotak yang menurut bapak/ibu paling tepat. Pertanyaan/pernyataan berikut ini berkaitan dengan pengaruh lingkungan kerja, motivasi kerja, kompensasi kepuasan , dan kinerja guru. Berikan jawaban sesuai dengan apa adanya yang bapak/ibu ketahui dan rasakan dengan kategori pilihan jawaban sebagai berikut:

\begin{tabular}{|l|}
\hline 5: sangat setuju dengan pertanyaan/pernyataan tersebut \\
\hline 4: setuju dengan pertanyaan/pernyataan tersebut \\
\hline 3: kurang setuju dengan pertanyaan/pernyataan tersebut \\
\hline 2: tidak setuju dengan pertanyaan/pernyataan tersebut \\
\hline 1: sangat tidak setuju dengan pertanyaan/pernyataan tersebut \\
\hline
\end{tabular}




\begin{tabular}{|c|c|c|c|c|c|c|}
\hline No. & Pernyataan & 5 & 4 & 3 & 2 & 1 \\
\hline 1 & $\begin{array}{l}\text { Ruangan tempat Anda bekerja } \\
\text { kebersihan dan kerapiannya } \\
\text { selalu terjaga }\end{array}$ & & & & & \\
\hline 2 & $\begin{array}{l}\text { Tidak ada suara bising dan } \\
\text { bau yang tidak sedap, yang } \\
\text { dapat } \\
\text { konsentrasi mengajar Anda }\end{array}$ & & & & & \\
\hline 3 & $\begin{array}{l}\text { Sekolah mempunyai petugas } \\
\text { keamanan yang siap setiap } \\
\text { saat menjaga keamanan }\end{array}$ & & & & & \\
\hline 4 & $\begin{array}{l}\text { Pimpinan sering memberikan } \\
\text { pengarahan, keyakinan dan } \\
\text { perhatian serta terjalin } \\
\text { komunikasi yang baik dengan } \\
\text { bawahan }\end{array}$ & & & & & \\
\hline 5 & $\begin{array}{l}\text { Terjalin komunikasi yang } \\
\text { baik antar sesama guru, dan } \\
\text { saling memberikan dukungan } \\
\text { moril antar guru }\end{array}$ & & & & & \\
\hline 6 & $\begin{array}{l}\text { Terjalin komunikasi yang } \\
\text { baik antar guru dan karyawan }\end{array}$ & & & & & \\
\hline 7 & $\begin{array}{l}\text { Anda akan menyelesaikan } \\
\text { tugas dengan baik untuk } \\
\text { meraih prestasi kerja yang } \\
\text { baik. }\end{array}$ & & & & & \\
\hline 8 & $\begin{array}{l}\text { Anda bekerja dengan baik } \\
\text { karena ada figure yang bisa } \\
\text { Anda jadikan panutan }\end{array}$ & & & & & \\
\hline 9 & $\begin{array}{l}\text { Anda berpikir realistis dalam } \\
\text { mencapai tujuan }\end{array}$ & & & & & \\
\hline 10 & $\begin{array}{l}\text { Hal yang Anda kerjakan } \\
\text { diikuti oleh rekan kerja yang } \\
\text { lain }\end{array}$ & & & & & \\
\hline 11 & $\begin{array}{l}\text { Anda melaksanakan dengan } \\
\text { penuh tanggung jawab }\end{array}$ & & & & & \\
\hline 12 & $\begin{array}{l}\text { Anda memberikan saran } \\
\text { kepada teman Anda , dan } \\
\text { saran Anda diikuti oleh rekan } \\
\text { kerja Anda }\end{array}$ & & & & & \\
\hline 13 & $\begin{array}{l}\text { Anda menjaga image } \text { Anda } \\
\text { sebagai guru agar bisa } \\
\text { diterima oleh orang lain }\end{array}$ & & & & & \\
\hline
\end{tabular}




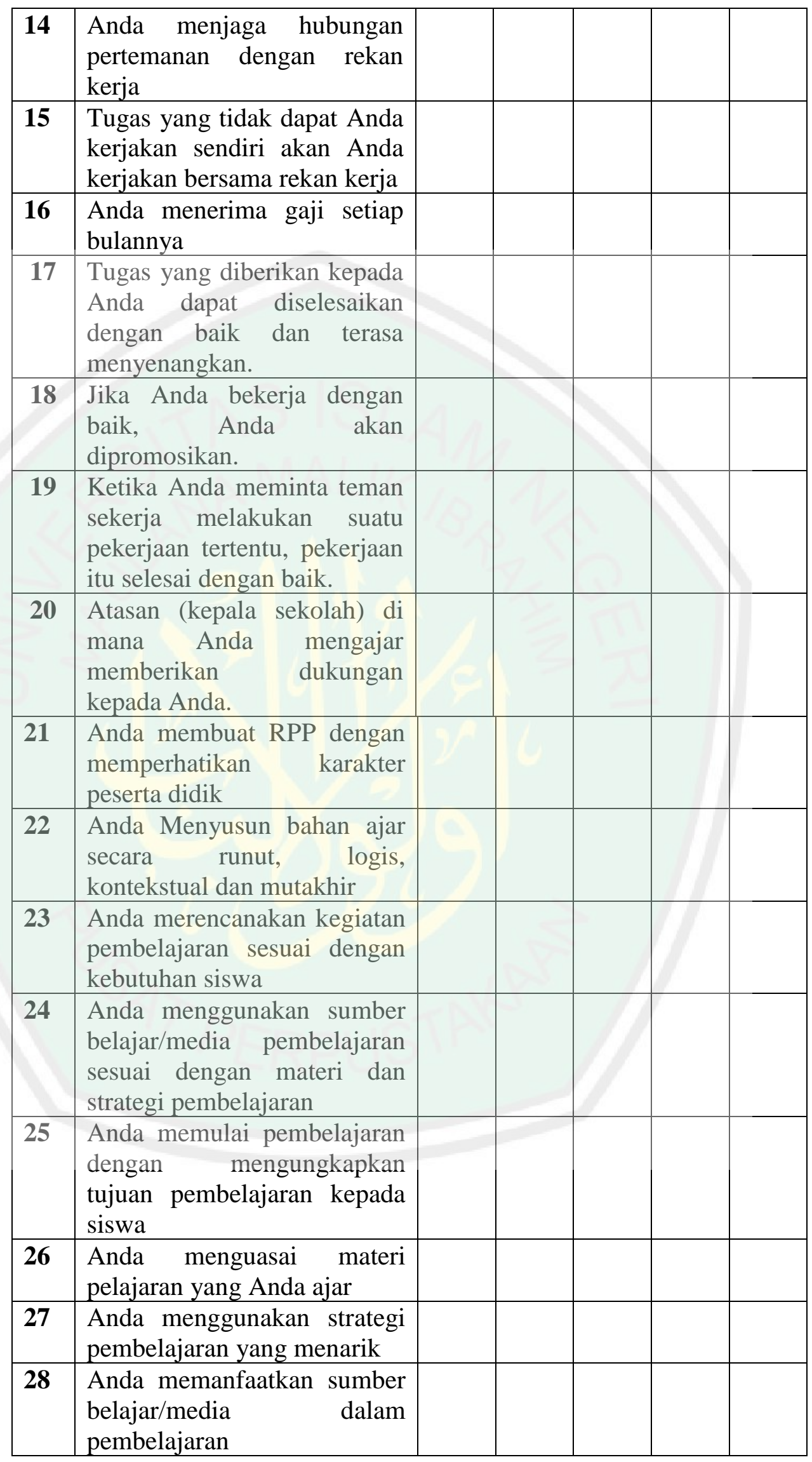




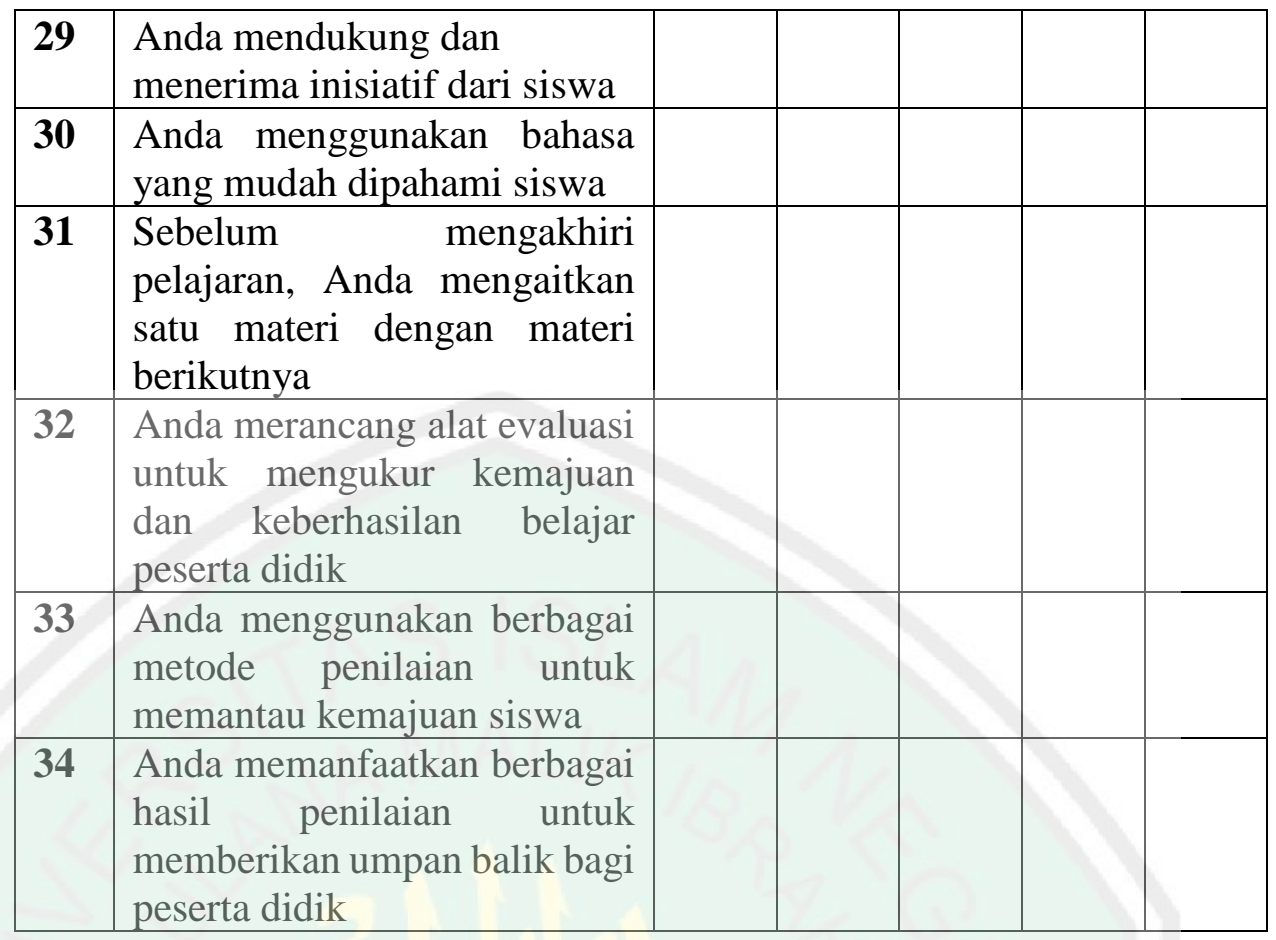




\section{Lampiran 2 Data uji Coba Angket}

Hasil Uji Coba Angket: Lingkungan Kerja

\begin{tabular}{|c|c|c|c|c|c|c|c|}
\hline No. & Item 1 & Item 2 & Item 3 & Item 4 & Item 5 & Item 6 & Total \\
\hline 1 & 4 & 4 & 4 & 4 & 4 & 4 & 24 \\
\hline 2 & 5 & 4 & 5 & 5 & 5 & 5 & 29 \\
\hline 3 & 4 & 3 & 4 & 4 & 5 & 5 & 25 \\
\hline 4 & 4 & 4 & 4 & 4 & 4 & 5 & 25 \\
\hline 5 & 5 & 4 & 5 & 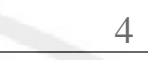 & 4 & 4 & 26 \\
\hline 6 & 4 & 4 & 4 & 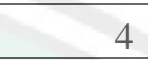 & 4 & 4 & 24 \\
\hline 7 & 5 & 4 & 4 & 4 & 4 & 3 & 24 \\
\hline 8 & 4 & 4 & 4 & 4 & 4 & 4 & 24 \\
\hline 9 & 5 & 5 & 4 & 4 & 5 & 5 & 28 \\
\hline 10 & 5 & 5 & 4 & 4 & 5 & 5 & 28 \\
\hline 11 & 4 & 3 & 4 & 5 & 5 & 5 & 26 \\
\hline 12 & 5 & 5 & 5 & 4 & 4 & 4 & 27 \\
\hline 13 & 3 & 4 & 2 & 5 & 4 & 5 & 23 \\
\hline 14 & 5 & 5 & 5 & 4 & 4 & 4 & 27 \\
\hline 15 & 5 & 5 & 3 & 5 & 5 & 4 & 27 \\
\hline 16 & 4 & 4 & 4 & 4 & 3 & 4 & 23 \\
\hline 17 & 3 & 4 & 3 & 4 & 4 & 4 & 22 \\
\hline 18 & 5 & 4 & 5 & 5 & 5 & 5 & 29 \\
\hline 19 & 4 & 4 & 4 & 5 & 5 & 5 & 27 \\
\hline 20 & 5 & 5 & 5 & 5 & 5 & 5 & 30 \\
\hline 21 & 4 & 3 & 4 & 5 & 5 & 4 & 25 \\
\hline 22 & 5 & 5 & 5 & 5 & 5 & 4 & 29 \\
\hline 23 & 5 & 5 & 5 & 4 & 4 & 4 & 27 \\
\hline 24 & 4 & 4 & 4 & 4 & 4 & 4 & 24 \\
\hline 25 & 4 & 4 & 4 & 5 & 5 & 4 & 26 \\
\hline 26 & 4 & 5 & 4 & 4 & 5 & 4 & 26 \\
\hline 27 & 4 & 4 & 4 & 5 & 5 & 5 & 27 \\
\hline 28 & 4 & 4 & 3 & 4 & 4 & 4 & 23 \\
\hline 29 & 4 & 4 & 5 & 5 & 5 & 5 & 28 \\
\hline 30 & 5 & 5 & 5 & 3 & 5 & 4 & 27 \\
\hline
\end{tabular}


Hasil Uji Coba Angket: Motivasi Kerja

\begin{tabular}{|c|c|c|c|c|c|c|c|c|c|c|c|}
\hline $\begin{array}{l}\mathrm{N} \\
\mathrm{O} .\end{array}$ & $\begin{array}{c}\text { Item } \\
1 \\
\end{array}$ & $\begin{array}{c}\text { Item } \\
2 \\
\end{array}$ & $\begin{array}{c}\text { Item } \\
3 \\
\end{array}$ & $\begin{array}{c}\text { Item } \\
4 \\
\end{array}$ & $\begin{array}{c}\text { Item } \\
5 \\
\end{array}$ & $\begin{array}{c}\text { Item } \\
6 \\
\end{array}$ & $\begin{array}{c}\text { Item } \\
7 \\
\end{array}$ & $\begin{array}{c}\text { Item } \\
8 \\
\end{array}$ & $\begin{array}{c}\text { Item } \\
9 \\
\end{array}$ & $\begin{array}{c}\text { Item } \\
10 \\
\end{array}$ & $\begin{array}{c}\text { Tot } \\
\text { al }\end{array}$ \\
\hline 1 & 5 & 5 & 5 & 4 & 5 & 4 & 5 & 5 & 4 & 4 & 46 \\
\hline 2 & 5 & 5 & 5 & 4 & 5 & 4 & 5 & 5 & 5 & 5 & 48 \\
\hline 3 & 4 & 4 & 5 & 3 & 4 & 4 & 4 & 5 & 5 & 5 & 43 \\
\hline 4 & 5 & 5 & 5 & 4 & 5 & 5 & 4 & 5 & 5 & 5 & 48 \\
\hline 5 & 4 & 3 & 4 & 3 & 4 & 3 & 4 & 5 & 4 & 4 & 38 \\
\hline 6 & 4 & 4 & 4 & 4 & 4 & 4 & 4 & 4 & 4 & 4 & 40 \\
\hline 7 & 4 & 4 & 4 & 4 & 4 & 4 & 4 & 4 & 4 & 4 & 40 \\
\hline 8 & 4 & 4 & 3 & 3 & 4 & 4 & 5 & 4 & 4 & 5 & 40 \\
\hline 9 & 5 & 5 & 4 & 3 & 4 & 3 & 4 & 4 & 4 & 5 & 41 \\
\hline 10 & 5 & 4 & 4 & 4 & 4 & 4 & 4 & 5 & 4 & 4 & 42 \\
\hline 11 & 5 & 5 & 5 & 4 & 4 & 4 & 4 & 5 & 5 & 3 & 44 \\
\hline 12 & 4 & 5 & 4 & 3 & 5 & 4 & 3 & 5 & 4 & 5 & 42 \\
\hline 13 & 4 & 4 & 4 & 3 & 4 & 4 & 3 & 5 & 4 & 3 & 38 \\
\hline 14 & 5 & 5 & 5 & 4 & 4 & 5 & 5 & 5 & 5 & 5 & 48 \\
\hline 15 & 5 & 4 & 4 & 3 & 4 & 4 & 4 & 4 & 4 & 4 & 40 \\
\hline 16 & 5 & 5 & 4 & 4 & 4 & 4 & 4 & 4 & 5 & 5 & 44 \\
\hline 17 & 3 & 3 & 4 & 3 & 3 & 4 & 3 & 4 & 4 & 4 & 35 \\
\hline 18 & 5 & 5 & 5 & 5 & 5 & 5 & 5 & 5 & 4 & 5 & 49 \\
\hline 19 & 4 & 3 & 5 & 4 & 5 & 5 & 4 & 5 & 5 & 5 & 45 \\
\hline 20 & 5 & 5 & 5 & 4 & 5 & 4 & 5 & 5 & 5 & 5 & 48 \\
\hline 21 & 4 & 4 & 4 & 3 & 4 & 5 & 4 & 4 & 4 & 4 & 40 \\
\hline 22 & 5 & 3 & 5 & 4 & 5 & 4 & 3 & 5 & 4 & 5 & 43 \\
\hline 23 & 4 & 4 & 5 & 4 & 4 & 4 & 4 & 4 & 4 & 4 & 41 \\
\hline 24 & 4 & 4 & 4 & 4 & 4 & 4 & 4 & 4 & 4 & 4 & 40 \\
\hline 25 & 5 & 5 & 5 & 4 & 5 & 4 & 4 & 5 & 5 & 5 & 47 \\
\hline 26 & 4 & 4 & 4 & 4 & 4 & 4 & 4 & 4 & 5 & 5 & 42 \\
\hline 27 & 4 & 4 & 5 & 4 & 5 & 5 & 5 & 5 & 4 & 4 & 45 \\
\hline 28 & 4 & 4 & 2 & 3 & 5 & 3 & 3 & 5 & 4 & 4 & 37 \\
\hline 29 & 4 & 4 & 4 & 3 & 4 & 4 & 3 & 4 & 3 & 5 & 38 \\
\hline 30 & 4 & 4 & 4 & 4 & 4 & 4 & 4 & 4 & 5 & 5 & 42 \\
\hline
\end{tabular}


Hasil Uji Coba Angket: Kepuasan Kerja

\begin{tabular}{|c|c|c|c|c|c|}
\hline No. & Item 1 & Item 2 & Item 3 & Item 4 & Total \\
\hline 1 & 4 & 4 & 4 & 4 & 16 \\
\hline 2 & 5 & 5 & 5 & 5 & 20 \\
\hline 3 & 4 & 3 & 3 & 4 & 14 \\
\hline 4 & 5 & 5 & 5 & 5 & 20 \\
\hline 5 & 3 & 3 & 3 & 4 & 13 \\
\hline 6 & 4 & 4 & 4 & 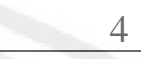 & 16 \\
\hline 7 & 4 & 4 & 4 & 5 & 17 \\
\hline 8 & 3 & 2 & 4 & 5 & 14 \\
\hline 9 & 4 & 3 & 3 & 5 & 15 \\
\hline 10 & 4 & 3 & 4 & 4 & 15 \\
\hline 11 & 5 & 4 & 4 & 5 & 18 \\
\hline 12 & 5 & 4 & 3 & 4 & 16 \\
\hline 13 & 5 & 3 & 3 & 5 & 16 \\
\hline 14 & 5 & 4 & 3 & 3 & 15 \\
\hline 15 & 4 & 3 & 4 & 4 & 15 \\
\hline 16 & 5 & 4 & 5 & 4 & 18 \\
\hline 17 & 3 & 4 & 3 & 4 & 14 \\
\hline 18 & 5 & 5 & 5 & 5 & 20 \\
\hline 19 & 4 & 3 & 4 & 4 & 15 \\
\hline 20 & 5 & 5 & 5 & 5 & 20 \\
\hline 21 & 4 & 3 & 3 & e & 14 \\
\hline 22 & 5 & 5 & 5 & 5 & 20 \\
\hline 23 & 4 & 5 & 5 & 4 & 18 \\
\hline 24 & 4 & 4 & 4 & 4 & 16 \\
\hline 25 & 5 & 4 & 4 & 5 & 18 \\
\hline 26 & 4 & 4 & 4 & 4 & 16 \\
\hline 27 & 5 & 4 & 4 & 4 & 17 \\
\hline 28 & 4 & 3 & 4 & 4 & 15 \\
\hline 29 & 4 & 4 & 4 & 4 & 16 \\
\hline 30 & 4 & 5 & 5 & 4 & 18 \\
\hline
\end{tabular}




\section{Hasil Uji Coba Angket: Kinerja Guru}

\begin{tabular}{|c|c|c|c|c|c|c|c|c|c|c|c|c|c|c|c|}
\hline $\begin{array}{l}\mathrm{N} \\
\mathrm{o} .\end{array}$ & $\begin{array}{c}\text { Ite } \\
\mathrm{m} \\
1\end{array}$ & $\begin{array}{c}\text { Ite } \\
\mathrm{m} \\
2\end{array}$ & $\begin{array}{c}\text { Ite } \\
\text { m } \\
3\end{array}$ & $\begin{array}{c}\text { Ite } \\
\mathrm{m} \\
4 \\
\end{array}$ & $\begin{array}{c}\text { Ite } \\
\mathrm{m} \\
5\end{array}$ & $\begin{array}{c}\text { Ite } \\
\mathrm{m} \\
6\end{array}$ & $\begin{array}{l}\text { Ite } \\
\mathrm{m} \\
7 \\
\end{array}$ & $\begin{array}{c}\text { Ite } \\
\text { m } \\
8\end{array}$ & $\begin{array}{r}\text { Ite } \\
\text { m } \\
9 \\
\end{array}$ & $\begin{array}{r}\text { Ite } \\
\mathrm{m} \\
10 \\
\end{array}$ & $\begin{array}{r}\text { Ite } \\
\mathrm{m} \\
11 \\
\end{array}$ & $\begin{array}{r}\text { Ite } \\
\mathrm{m} \\
12 \\
\end{array}$ & $\begin{array}{r}\text { Ite } \\
\mathrm{m} \\
13 \\
\end{array}$ & $\begin{array}{r}\text { Ite } \\
\mathrm{m} \\
15 \\
\end{array}$ & $\begin{array}{l}\text { To } \\
\text { tal }\end{array}$ \\
\hline 1 & 4 & 4 & 4 & 4 & 4 & 4 & 4 & 4 & 4 & 4 & 4 & 4 & 4 & 4 & 56 \\
\hline 2 & 5 & 5 & 5 & 5 & 5 & 5 & 5 & 5 & 5 & 5 & 5 & 5 & 5 & 5 & 70 \\
\hline 3 & 4 & 4 & 4 & 5 & 4 & 4 & 4 & 4 & 4 & 4 & 4 & 4 & 5 & 5 & 59 \\
\hline 4 & 5 & 5 & 5 & 5 & 5 & 4 & 4 & 4 & 5 & 4 & 4 & 4 & 5 & 5 & 64 \\
\hline 5 & 4 & 4 & 4 & 4 & 4 & 4 & 4 & 4 & 4 & 4 & 4 & 4 & 3 & 4 & 55 \\
\hline 6 & 4 & 4 & 4 & 4 & 4 & 4 & 4 & 4 & 4 & 4 & 4 & 4 & 4 & 4 & 56 \\
\hline 7 & 5 & 5 & 4 & 4 & 4 & 3 & 4 & 4 & 4 & 4 & 4 & 4 & 4 & 4 & 57 \\
\hline 8 & 4 & 4 & 4 & 5 & 4 & 4 & 4 & 4 & 4 & 5 & 4 & 4 & 5 & 4 & 59 \\
\hline 9 & 3 & 4 & 5 & 3 & 4 & 5 & 4 & 3 & 4 & 4 & 3 & 4 & 4 & 4 & 54 \\
\hline $\begin{array}{l}1 \\
0 \\
\end{array}$ & 4 & 4 & 4 & 4 & 4 & 4 & 4 & 4 & 4 & 4 & 4 & 4 & 4 & 4 & 56 \\
\hline $\begin{array}{l}1 \\
1 \\
\end{array}$ & 4 & 4 & 4 & 4 & 4 & 4 & 4 & 4 & 4 & 4 & 3 & 3 & 4 & 4 & 54 \\
\hline $\begin{array}{l}1 \\
2 \\
\end{array}$ & 4 & 3 & 5 & 5 & 4 & 4 & 4 & 5 & 5 & 4 & 4 & 4 & 4 & 4 & 59 \\
\hline $\begin{array}{l}1 \\
3 \\
\end{array}$ & 5 & 4 & 4 & 4 & 4 & 4 & 4 & 4 & 4 & 4 & 4 & 5 & 5 & 4 & 59 \\
\hline $\begin{array}{l}1 \\
4 \\
\end{array}$ & 3 & 5 & 5 & 4 & 3 & 5 & 4 & 5 & 5 & 4 & 3 & 5 & 5 & 5 & 61 \\
\hline $\begin{array}{l}1 \\
5 \\
\end{array}$ & 4 & 4 & 4 & 4 & 4 & 4 & 4 & 4 & 4 & 4 & 4 & 4 & 4 & 4 & 56 \\
\hline $\begin{array}{l}1 \\
6\end{array}$ & 4 & 4 & 4 & 3 & 4 & 4 & 4 & 4 & 4 & 5 & 4 & 3 & 4 & 4 & 55 \\
\hline $\begin{array}{l}1 \\
7\end{array}$ & 3 & 3 & 3 & 5 & 4 & 4 & 3 & 3 & 4 & 3 & 3 & 3 & 3 & 3 & 47 \\
\hline $\begin{array}{l}1 \\
8 \\
\end{array}$ & 5 & 5 & 5 & 5 & 5 & 5 & 5 & 5 & 5 & 5 & 5 & 5 & 5 & 5 & 70 \\
\hline $\begin{array}{l}1 \\
9 \\
\end{array}$ & 5 & 4 & 3 & 4 & 5 & 4 & 4 & 5 & 5 & 5 & 4 & 5 & 4 & 4 & 61 \\
\hline $\begin{array}{l}2 \\
0\end{array}$ & 5 & 5 & 5 & 5 & 5 & 5 & 5 & 5 & 5 & 5 & 5 & 5 & 5 & 5 & 70 \\
\hline $\begin{array}{l}2 \\
1 \\
\end{array}$ & 3 & 4 & 5 & 5 & 4 & 4 & 4 & 5 & 4 & 4 & 4 & 4 & 4 & 4 & 58 \\
\hline $\begin{array}{l}2 \\
2 \\
\end{array}$ & 5 & 5 & 5 & 5 & 5 & 5 & 5 & 5 & 5 & 5 & 4 & 4 & 4 & 5 & 67 \\
\hline $\begin{array}{l}2 \\
3 \\
\end{array}$ & 4 & 4 & 4 & 4 & 4 & 4 & 4 & 4 & 4 & 4 & 4 & 4 & 4 & 4 & 56 \\
\hline $\begin{array}{l}2 \\
4 \\
\end{array}$ & 4 & 4 & 4 & 4 & 4 & 4 & 4 & 4 & 4 & 4 & 4 & 4 & 4 & 4 & 56 \\
\hline $\begin{array}{l}2 \\
5 \\
\end{array}$ & 4 & 5 & 4 & 4 & 5 & 4 & 5 & 5 & 5 & 5 & 5 & 5 & 5 & 5 & 66 \\
\hline $\begin{array}{l}2 \\
6 \\
\end{array}$ & 4 & 4 & 4 & 4 & 4 & 4 & 4 & 4 & 4 & 4 & 4 & 4 & 4 & 4 & 56 \\
\hline $\begin{array}{l}2 \\
7 \\
\end{array}$ & 4 & 4 & 4 & 4 & 4 & 4 & 4 & 4 & 4 & 4 & 4 & 4 & 4 & 4 & 56 \\
\hline $\begin{array}{l}2 \\
8 \\
\end{array}$ & 4 & 4 & 4 & 4 & 4 & 4 & 4 & 4 & 4 & 4 & 4 & 3 & 4 & 4 & 55 \\
\hline $\begin{array}{l}2 \\
9 \\
\end{array}$ & 4 & 4 & 3 & 5 & 4 & 4 & 4 & 4 & 4 & 4 & 4 & 4 & 4 & 4 & 56 \\
\hline $\begin{array}{l}3 \\
0\end{array}$ & 4 & 4 & 4 & 4 & 4 & 4 & 4 & 4 & 4 & 4 & 4 & 4 & 4 & 4 & 56 \\
\hline
\end{tabular}




\section{Lampiran 3 Uji Coba Normalitas Dan Lineiritas Angket}

\section{$\mathbf{X}_{1}, \mathbf{X}_{2}$ Terhadap Z}

One-Sample Kolmogorov-Smirnov Test

\begin{tabular}{|ll|r|}
\hline & & \multicolumn{1}{|c|}{ z } \\
\hline Normal Parameters & a,b & Mean \\
& Std. Deviation &, 0000000 \\
Most Extreme Differences & 1,34439491 \\
& Absolute &, 112 \\
& Positive &, 083 \\
& Negative &,- 112 \\
Test Statistic & &, 112 \\
Asymp. Sig. (2-tailed) & &, 200 \\
\hline
\end{tabular}

nilai signifikansi 0,200 dan lebih besar 0,05 maka data terdistribusi normal

ANOVA Table

\begin{tabular}{|ll|r|r|r|r|r|}
\hline & \multicolumn{1}{c}{$\begin{array}{c}\text { Sum of } \\
\text { Squares }\end{array}$} & Df & \multicolumn{1}{c|}{$\begin{array}{c}\text { Mean } \\
\text { Square }\end{array}$} & \multicolumn{1}{c|}{ F } & \multicolumn{1}{c|}{ Sig. } \\
\hline Groups & (Combined) & 63,188 & 8 & 7,899 & 2,662 &, 034 \\
& $\begin{array}{l}\text { Linearity } \\
\text { Deviation from } \\
\text { Linearity }\end{array}$ & 37,805 & 7 & 5,401 & 1,820 &, 136 \\
\hline Within Groups & 62,312 & 21 & 2,967 & & \\
\hline Total & 125,500 & 29 & & & \\
\hline
\end{tabular}

ANOVA Table

\begin{tabular}{|c|c|c|c|c|c|c|}
\hline & & $\begin{array}{l}\text { Sum of } \\
\text { Squares }\end{array}$ & Df & $\begin{array}{c}\text { Mean } \\
\text { Square }\end{array}$ & $\mathrm{F}$ & Sig. \\
\hline \multirow{3}{*}{$\begin{array}{c}z^{*} \text { x2 } \\
\text { Between } \\
\text { Groups }\end{array}$} & (Combined) & 64,167 & 12 & 5,347 & 1,482 &, 223 \\
\hline & Linearity & 52,111 & 1 & 52,111 & 14,444 & 001 \\
\hline & $\begin{array}{l}\text { Deviation from } \\
\text { Linearity }\end{array}$ & 12,056 & 11 & 1,096 & ,304 & ,975 \\
\hline \multicolumn{2}{|c|}{ Within Groups } & 61,333 & 17 & 3,608 & & \\
\hline \multicolumn{2}{|l|}{ Total } & 125,500 & 29 & & & \\
\hline
\end{tabular}

nilai signifikansi lebih besar dari 0,05 maka $\mathrm{X}_{1}, \mathrm{X}_{2}$. linier terhadap $\mathrm{Z}$ 


\section{$\mathbf{X}_{1}, \mathbf{X}_{2}$ Terhadap $\mathbf{Y}$}

\begin{tabular}{|ll|r|}
\multicolumn{2}{c}{ One-Sample Kolmogorov-Smirnov Test } \\
\hline Normal Parameters & \multicolumn{1}{|c|}{ y } & 30 \\
& Mean &, 0000000 \\
Nost Extreme Differences & Std. Deviation & 3,36763288 \\
& Absolute &, 121 \\
& Positive &, 121 \\
& Negative &,- 107 \\
Test Statistic & &, 121 \\
Asymp. Sig. (2-tailed) & &, 200 \\
\hline
\end{tabular}

nilai signifikansi 0,200 dan lebih besar 0,05 maka data terdistribusi normal

ANOVA Table

\begin{tabular}{|c|c|c|c|c|c|c|c|}
\hline & & & $\begin{array}{l}\text { Sum of } \\
\text { Squares }\end{array}$ & df & $\begin{array}{l}\text { Mean } \\
\text { Square }\end{array}$ & $\mathrm{F}$ & Sig. \\
\hline \multirow{5}{*}{$y^{*} x 1$} & & (Combined) & 668,260 & 8 & 83,532 & 10,058 & ,000 \\
\hline & Groups & Linearity & 294,031 & 1 & 294,031 & 35,404 & ,000 \\
\hline & & $\begin{array}{l}\text { Deviation from } \\
\text { Linearity }\end{array}$ & 374,228 & 7 & 53,461 & 1,737 &, 170 \\
\hline & Within Groups & & 174,407 & 21 & 8,305 & & \\
\hline & Total & & 842,667 & 29 & & & \\
\hline
\end{tabular}

ANOVA Table

\begin{tabular}{|c|c|c|c|c|c|c|c|}
\hline & & & $\begin{array}{l}\text { Sum of } \\
\text { Squares }\end{array}$ & Df & $\begin{array}{l}\text { Mean } \\
\text { Square }\end{array}$ & $\mathrm{F}$ & Sig. \\
\hline \multirow{5}{*}{$y^{*} x 2$} & Between & (Combined) & 711,500 & 12 & 59,292 & 7,685 & ,000 \\
\hline & \multirow[t]{2}{*}{ Groups } & Linearity & 457,568 & 1 & 457,568 & 59,304 &, 000 \\
\hline & & $\begin{array}{l}\text { Deviation from } \\
\text { Linearity }\end{array}$ & 253,932 & 11 & 23,085 & 2,992 & ,210 \\
\hline & \multicolumn{2}{|c|}{ Within Groups } & 131,167 & 17 & 7,716 & & \\
\hline & \multicolumn{2}{|l|}{ Total } & 842,667 & 29 & & & \\
\hline
\end{tabular}

nilai signifikansi lebih besar dari 0,05 maka $\mathrm{X}_{1}, \mathrm{X}_{2}$. linier terhadap $\mathrm{Z}$ 


\section{Z Terhadap Y}

One-Sample Kolmogorov-Smirnov Test

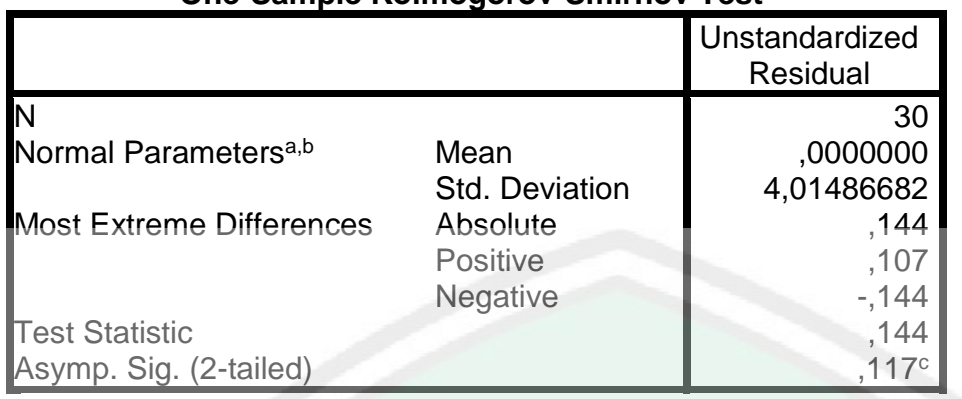

nilai signifikansi 0,200 dan lebih besar 0,05 maka data terdistribusi normal

ANOVA Table

\begin{tabular}{|c|c|c|c|c|c|c|c|}
\hline & & & $\begin{array}{l}\text { Sum of } \\
\text { Squares }\end{array}$ & Df & $\begin{array}{c}\text { Mean } \\
\text { Square }\end{array}$ & $\mathrm{F}$ & Sig. \\
\hline \multirow[t]{5}{*}{$y^{*} z$} & \multirow{3}{*}{$\begin{array}{l}\text { Between } \\
\text { Groups }\end{array}$} & (Combined) & 555,726 & 6 & 92,621 & 7,424 &, 000 \\
\hline & & Linearity & 375,211 & 1 & 375,211 & 30,075 &, 000 \\
\hline & & $\begin{array}{l}\text { Deviation from } \\
\text { Linearity }\end{array}$ & 180,515 & 5 & 36,103 & 2,894 & ,360 \\
\hline & \multicolumn{2}{|c|}{ Within Groups } & 286,940 & 23 & 12,476 & & \\
\hline & \multicolumn{2}{|l|}{ Total } & 842,667 & 29 & & & \\
\hline
\end{tabular}

nilai signifikansi lebih besar dari 0,05 maka Zlinier terhadap Y 


\section{Lampiran 4 Uji validitas dan reliabilitas}

\section{Item Lingkungan kerja}

\begin{tabular}{|c|c|c|c|c|c|c|c|c|}
\hline \multicolumn{9}{|c|}{ Correlations } \\
\hline & & $\begin{array}{c}\text { VAR00 } \\
001\end{array}$ & \begin{tabular}{|c|} 
VAR00 \\
002
\end{tabular} & \begin{tabular}{|c|} 
VAR00 \\
003
\end{tabular} & $\begin{array}{c}\text { VAR00 } \\
004\end{array}$ & $\begin{array}{l}\text { VAR00 } \\
005\end{array}$ & $\begin{array}{l}\text { VAR00 } \\
006\end{array}$ & $\begin{array}{c}\text { TOTA } \\
\mathrm{L}\end{array}$ \\
\hline \multirow[t]{3}{*}{$\begin{array}{l}\text { VAR00 } \\
001\end{array}$} & $\begin{array}{l}\text { Pearson } \\
\text { Correlation }\end{array}$ & 1 &, $576^{\star *}$ &, $688^{* *}$ &,- 104 & ,245 &,- 104 &, $721^{* *}$ \\
\hline & Sig. (2-tailed) & &, 001 &, 000 &, 584 & , 192 & ,584 &, 000 \\
\hline & $\mathrm{N}$ & 30 & 30 & 30 & 30 & 30 & 30 & 30 \\
\hline \multirow[t]{3}{*}{$\begin{array}{l}\text { VAR00 } \\
002\end{array}$} & $\begin{array}{l}\text { Pearson } \\
\text { Correlation }\end{array}$ &, $576^{* *}$ & 1 & ,283 &,- 254 & ,048 &,- 155 &, $472^{* *}$ \\
\hline & Sig. (2-tailed) & ,001 & & , 130 &, 175 & ,801 & ,413 & ,008 \\
\hline & $\mathrm{N}$ & 30 & 30 & 30 & 30 & 30 & 30 & 30 \\
\hline \multirow[t]{3}{*}{$\begin{array}{l}\text { VAR00 } \\
003\end{array}$} & $\begin{array}{l}\text { Pearson } \\
\text { Correlation }\end{array}$ &, $688^{* *}$ & ,283 & 1 &,- 069 & & ,014 & \\
\hline & Sig. (2-tailed) &, 000 & , 130 & & ,716 & ,285 & ,942 &, 000 \\
\hline & $\mathrm{N}$ & 30 & 30 & 30 & 30 & 30 & 30 & 30 \\
\hline \multirow[t]{3}{*}{$\begin{array}{l}\text { VAR00 } \\
004\end{array}$} & $\begin{array}{l}\text { Pearson } \\
\text { Correlation }\end{array}$ &,- 104 &,- 254 &,- 069 & 1 &, $488^{* *}$ & & ,384* \\
\hline & Sig. (2-tailed) &, 584 & ,175 & ,716 & & ,006 & ,014 & ,036 \\
\hline & $\mathrm{N}$ & 30 & 30 & 30 & 30 & 30 & 30 & 30 \\
\hline \multirow[t]{3}{*}{$\begin{array}{l}\text { VAR00 } \\
005\end{array}$} & $\begin{array}{l}\text { Pearson } \\
\text { Correlation }\end{array}$ & ,245 & ,048 & ,202 & & 1 & &, $688^{* *}$ \\
\hline & Sig. (2-tailed) & , 192 & ,801 & ,285 &, 006 & & ,006 &, 000 \\
\hline & $\mathrm{N}$ & 30 & 30 & 30 & 30 & 30 & 30 & 30 \\
\hline \multirow[t]{3}{*}{$\begin{array}{l}\text { VAR00 } \\
006\end{array}$} & $\begin{array}{l}\text { Pearson } \\
\text { Correlation }\end{array}$ &,- 104 &,- 155 &, 014 &, $442^{*}$ & & 1 & \\
\hline & Sig. (2-tailed) &, 584 & ,413 &, 942 &, 014 & ,006 & & ,014 \\
\hline & $\mathrm{N}$ & 30 & 30 & 30 & 30 & 30 & 30 & 30 \\
\hline \multirow[t]{3}{*}{ TOTAL } & $\begin{array}{l}\text { Pearson } \\
\text { Correlation }\end{array}$ &, $721^{* *}$ &, $472^{* \star}$ &, $681^{\star *}$ &, $384^{*}$ &, $688^{* *}$ & ,443* & 1 \\
\hline & Sig. (2-tailed) & ,000 & ,008 & ,000 & ,036 & ,000 & ,014 & \\
\hline & $\mathrm{N}$ & 30 & 30 & 30 & 30 & 30 & 30 & 30 \\
\hline
\end{tabular}

**. Correlation is significant at the 0.01 level (2-tailed).

*. Correlation is significant at the 0.05 level (2-tailed). 


\section{Reliability}

\begin{tabular}{|c|c|c|c|}
\hline \multicolumn{4}{|c|}{ Case Processing Summary } \\
\hline & & $\mathrm{N}$ & $\%$ \\
\hline Cases & Valid & 30 & 100,0 \\
\hline & Excluded $^{\mathrm{a}}$ & 0 & 0 \\
\hline & Total & 30 & 100,0 \\
\hline
\end{tabular}

a. Listwise deletion based on all variables in the procedure.

Reliability Statistics

\begin{tabular}{|r|r|}
\hline Cronbach's Alpha & N of Items \\
\hline, 582 & 6 \\
\hline
\end{tabular}

Item-Total Statistics

\begin{tabular}{|lr|r|r|r|}
\hline & $\begin{array}{r}\text { Scale Mean if Item } \\
\text { Deleted }\end{array}$ & $\begin{array}{c}\text { Scale Variance if } \\
\text { Item Deleted }\end{array}$ & $\begin{array}{c}\text { Corrected Item- } \\
\text { Total Correlation }\end{array}$ & $\begin{array}{c}\text { Cronbach's Alpha } \\
\text { if Item Deleted }\end{array}$ \\
\hline VAR00001 & 21,6333 & 2,930 &, 525 &, 441 \\
VAR00002 & 21,7667 & 3,564 &, 194 &, 590 \\
VAR00003 & 21,8333 & 2,833 &, 407 &, 493 \\
VAR00004 & 21,6333 & 3,826 &, 128 &, 608 \\
VAR00005 & 21,5000 & 3,086 &, 497 &, 462 \\
VAR00006 & 21,6333 & 3,689 &, 195 &, 584 \\
\hline
\end{tabular}


motivasi kerja

Correlations

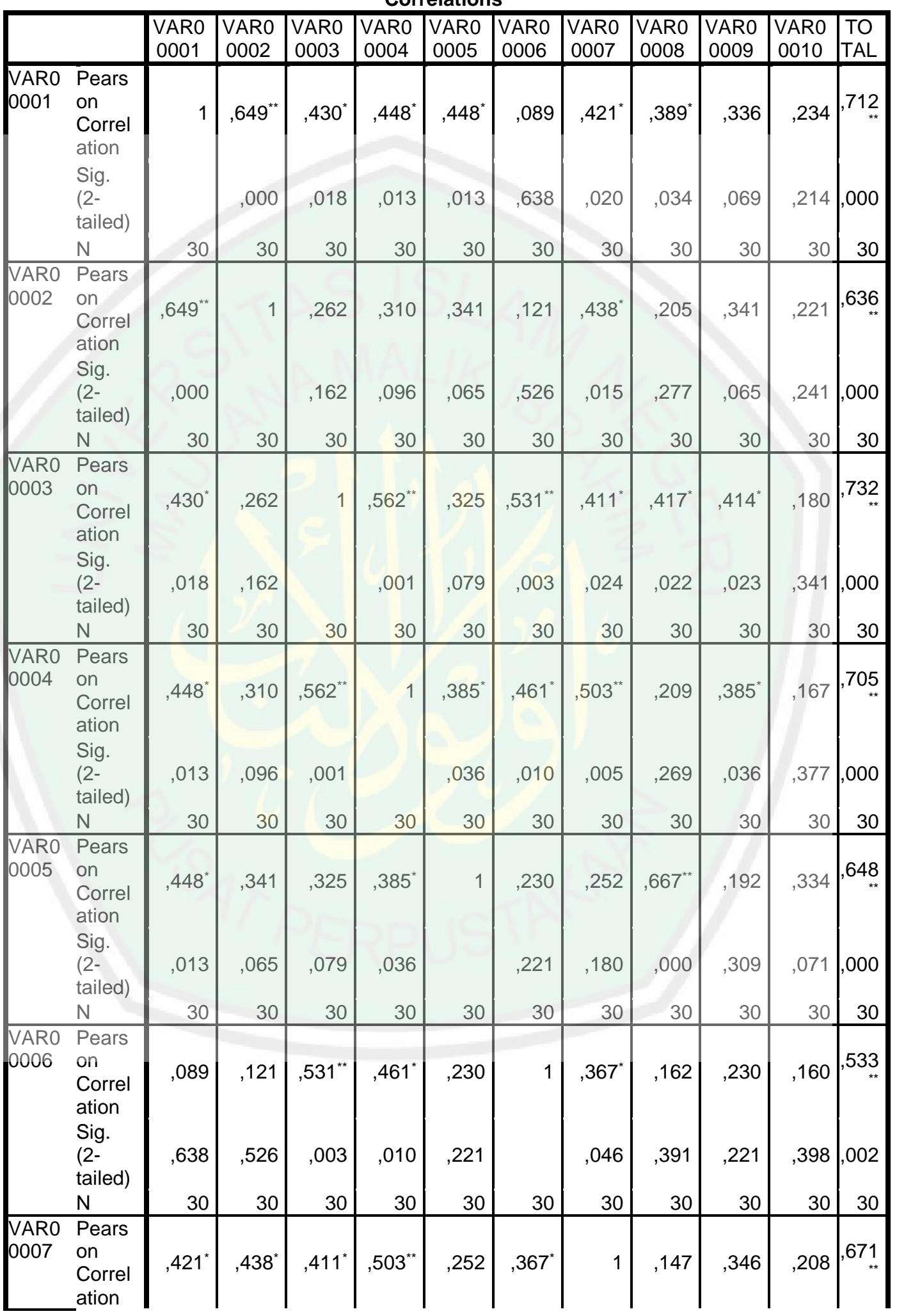




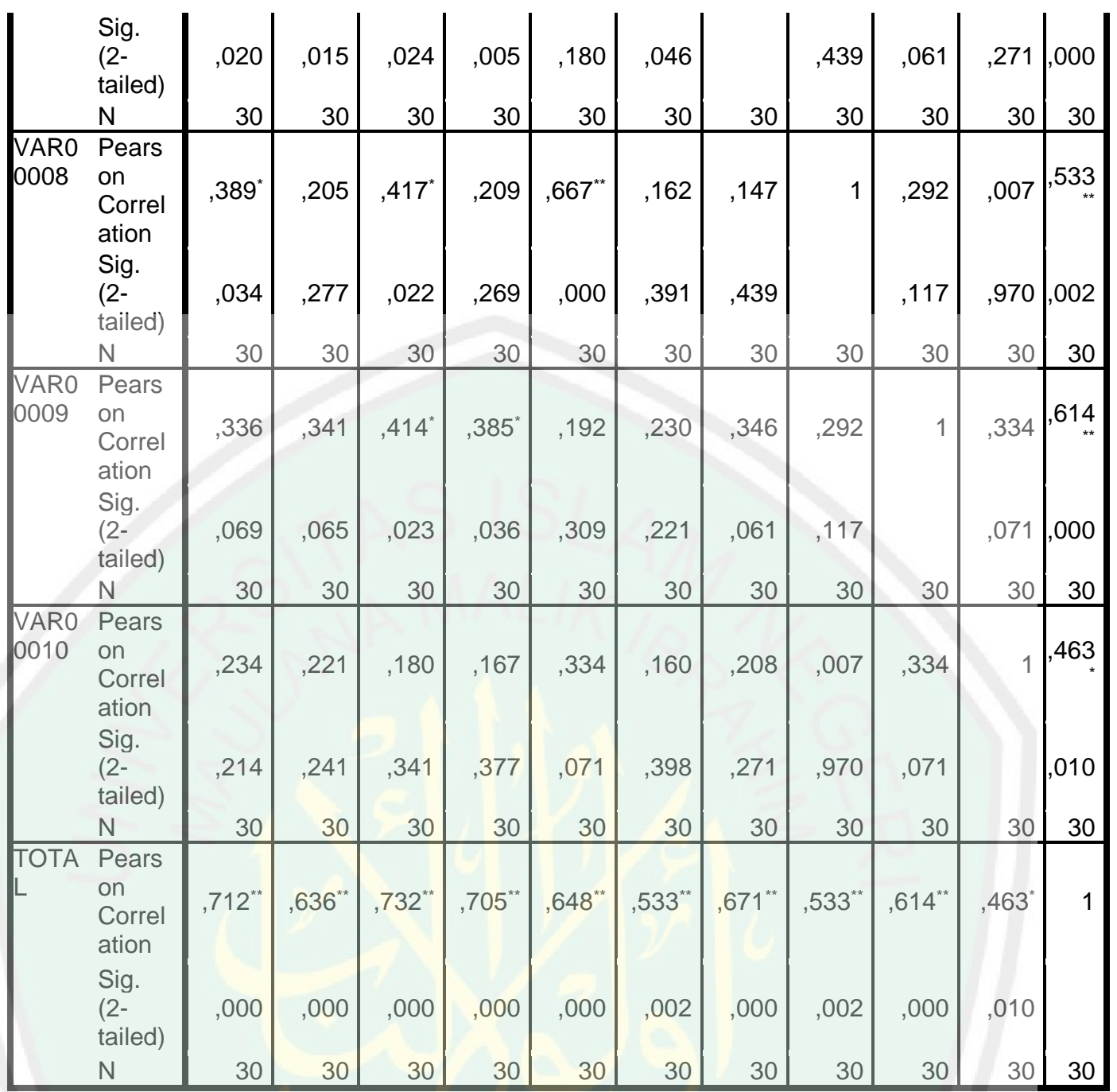

**. Correlation is significant at the 0.01 level (2-tailed).

*. Correlation is significant at the 0.05 level (2-tailed).

\section{Reliability}

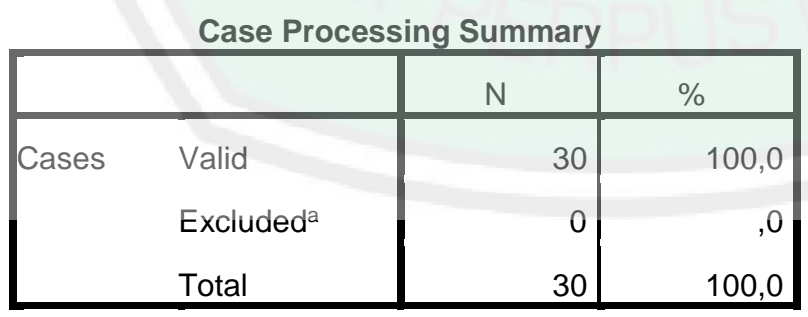

a. Listwise deletion based on all variables in the procedure.

Reliability Statistics

Cronbach's Alpha $\quad \mathrm{N}$ of Items 


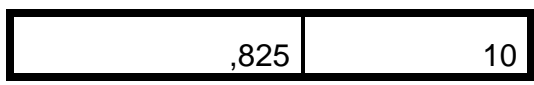

Item-Total Statistics

\begin{tabular}{|l|r|r|r|r|}
\hline & $\begin{array}{r}\text { Scale Mean if Item } \\
\text { Deleted }\end{array}$ & $\begin{array}{c}\text { Scale Variance if } \\
\text { Item Deleted }\end{array}$ & $\begin{array}{c}\text { Corrected Item- } \\
\text { Total Correlation }\end{array}$ & $\begin{array}{c}\text { Cronbach's Alpha } \\
\text { if Item Deleted }\end{array}$ \\
\hline VAR00001 & 38,0667 & 11,237 &, 625 &, 799 \\
VAR00002 & 38,2333 &, 508 &, 811 \\
VAR00003 & 38,1333 & 11,151 &, 623 &, 797 \\
VAR00004 & 38,8000 & 10,533 &, 618 &, 800 \\
VAR00005 & 38,1333 & 11,338 &, 550 &, 806 \\
VAR00006 & 38,3667 & 11,568 &, 416 &, 819 \\
VAR00007 & 38,4333 & 12,033 &, 553 &, 805 \\
VAR00008 & 37,9000 & 11,013 &, 426 &, 818 \\
VAR00009 & 38,1333 & 12,162 &, 510 &, 810 \\
VAR00010 & 38,0000 & 11,706 &, 315 &, 830 \\
\hline
\end{tabular}




\section{kepuasan kerja}

\begin{tabular}{|c|c|c|c|c|c|c|}
\hline \multicolumn{7}{|c|}{ Correlations } \\
\hline & & VAR00001 & VAR00002 & VAR00003 & VAR00004 & total \\
\hline \multirow[t]{3}{*}{ VAR00001 } & Pearson Correlation & 1 &, $530^{\star *}$ & ,356 & ,291 &, $725^{* *}$ \\
\hline & Sig. (2-tailed) & &, 003 & ,053 & ,119 &, 000 \\
\hline & $\mathrm{N}$ & 30 & 30 & 30 & 30 & 30 \\
\hline \multirow[t]{3}{*}{ VAR00002 } & Pearson Correlation &, $530^{\star \star}$ & 1 &, $680^{* \star}$ &, 180 &, $850^{\star \star}$ \\
\hline & Sig. (2-tailed) &, 003 & &, 000 & ,342 &, 000 \\
\hline & $\mathrm{N}$ & 30 & 30 & 30 & 30 & 30 \\
\hline \multirow[t]{3}{*}{ VAR00003 } & Pearson Correlation & ,356 &, $680^{* *}$ & 1 & ,340 & $826^{* *}$ \\
\hline & Sig. (2-tailed) & ,053 &, 000 & & ,066 &, 000 \\
\hline & $\mathrm{N}$ & 30 & 30 & 30 & 30 & 30 \\
\hline \multirow[t]{3}{*}{ VAR00004 } & Pearson Correlation & ,291 & , 180 & ,340 & 1 &, $546^{* *}$ \\
\hline & Sig. (2-tailed) & ,119 & ,342 & ,066 & & ,002 \\
\hline & $\mathrm{N}$ & 30 & 30 & 30 & 30 & 30 \\
\hline \multirow[t]{3}{*}{ total } & Pearson Correlation &, $725^{\star *}$ & ,850** &, $826^{\star *}$ &, $546^{* *}$ & 1 \\
\hline & Sig. (2-tailed) &, 000 &, 000 &, 000 &, 002 & \\
\hline & $\mathrm{N}$ & 30 & 30 & 30 & 30 & 30 \\
\hline
\end{tabular}

. Correlation is significant at the 0.01 level (2-tailed).

\section{Reliability}

\begin{tabular}{|c|c|c|c|}
\hline & & $\mathrm{N}$ & $\%$ \\
\hline \multirow[t]{3}{*}{ Cases } & Valid & 30 & 100,0 \\
\hline & Excluded $^{a}$ & 0 & ,0 \\
\hline & Total & 30 & 100,0 \\
\hline
\end{tabular}

a. Listwise deletion based on all variables in the procedure.

\section{Reliability Statistics}

\begin{tabular}{|r|l|}
\hline Cronbach's Alpha & N of Items \\
\hline, 734 & \\
\hline
\end{tabular}

\begin{tabular}{|l|r|r|r|r|}
\hline & $\begin{array}{c}\text { Scale Mean if Item } \\
\text { Deleted }\end{array}$ & $\begin{array}{c}\text { Scale Variance if } \\
\text { Item Deleted }\end{array}$ & $\begin{array}{c}\text { Corrected Item- } \\
\text { Total Correlation }\end{array}$ & $\begin{array}{c}\text { Cronbach's Alpha } \\
\text { if Item Deleted }\end{array}$ \\
\hline VAR00001 & 12,2000 & 2,786 &, 514 &, 681 \\
VAR00002 & 12,6333 & 2,102 &, 654 &, 590 \\
VAR00003 & 12,5000 & 2,328 &, 639 &, 601 \\
VAR00004 & 12,1667 & 3,385 &, 320 &, 770 \\
\hline
\end{tabular}


kinerja guru

Correlations

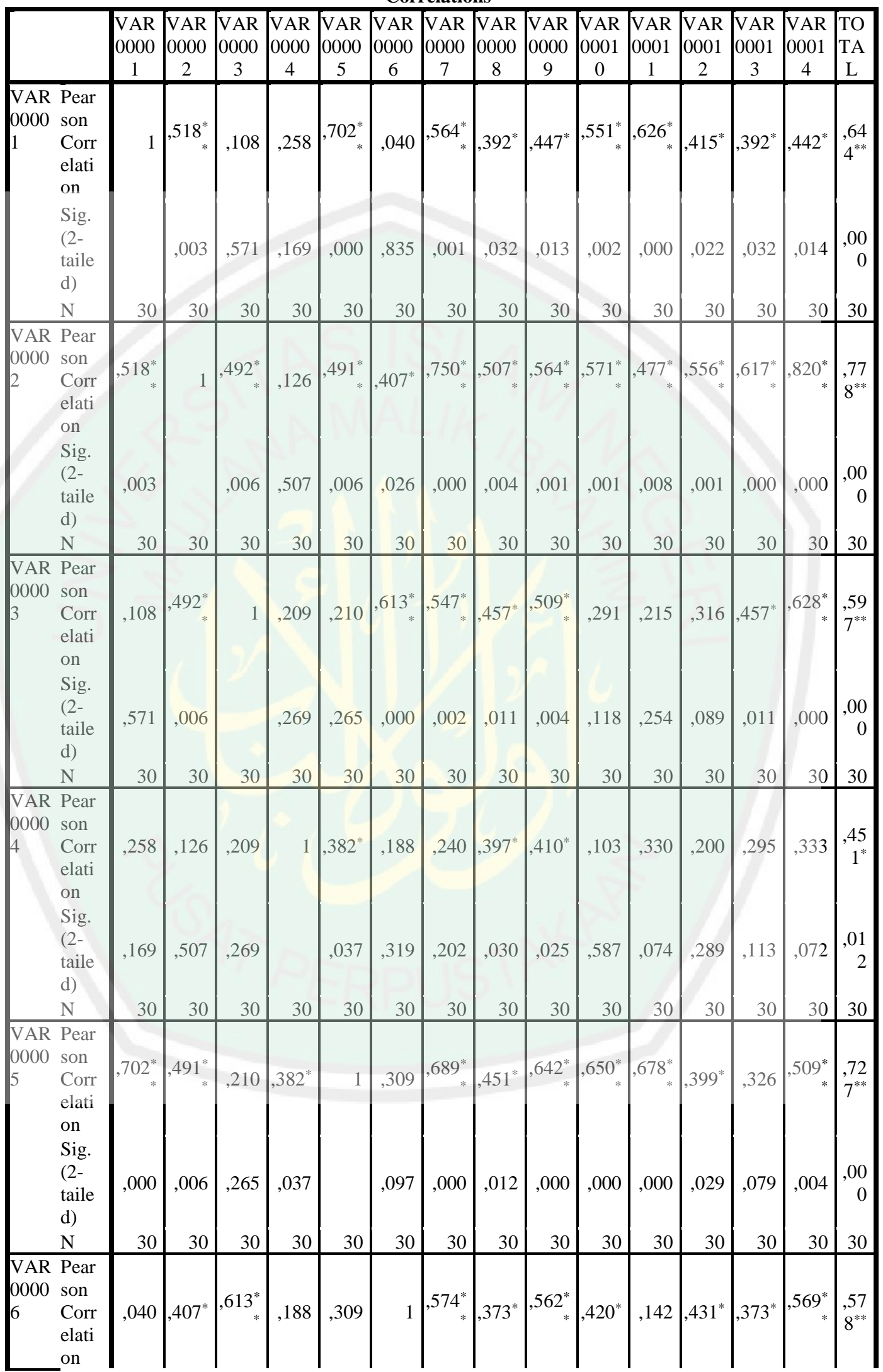




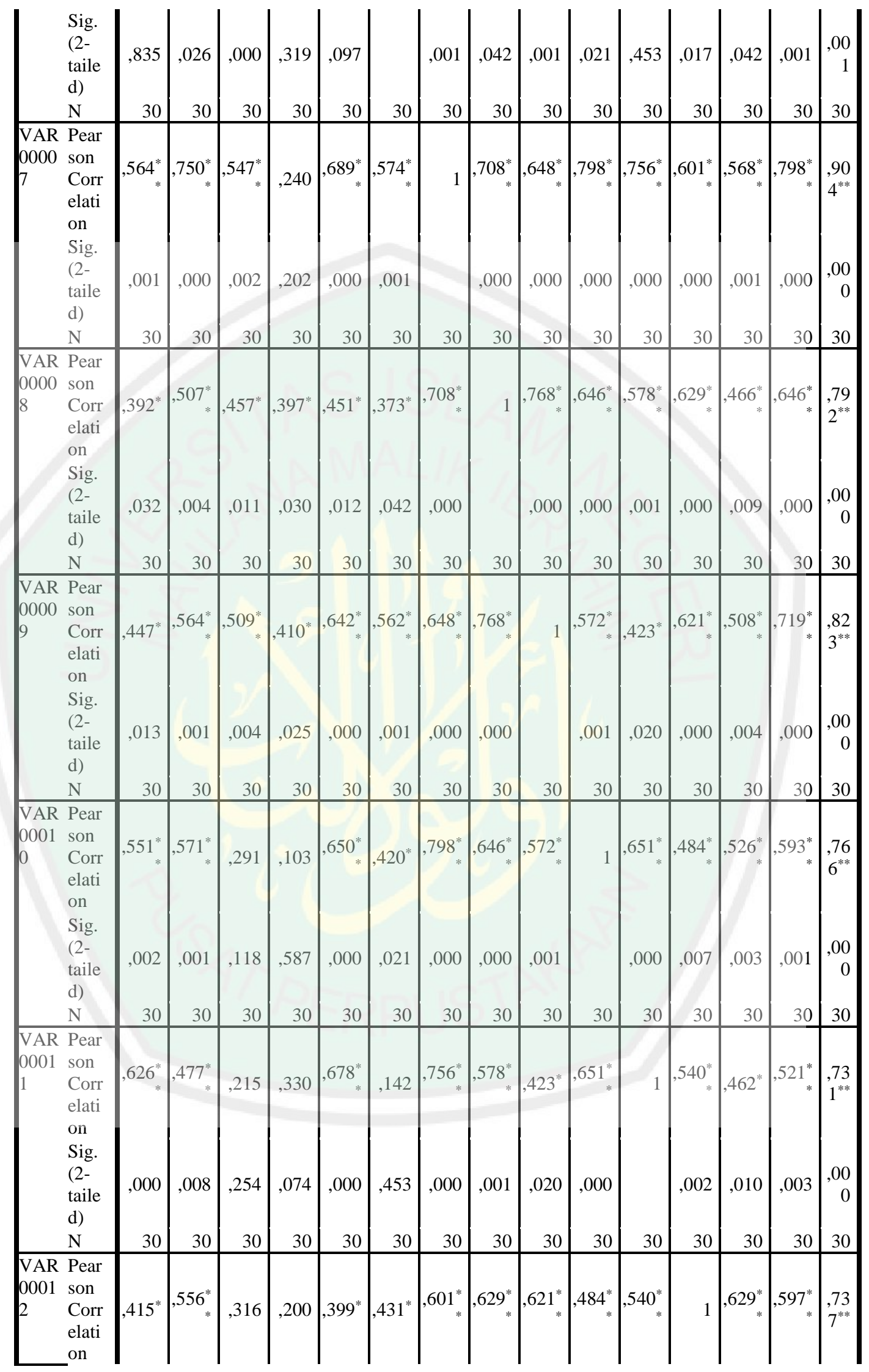




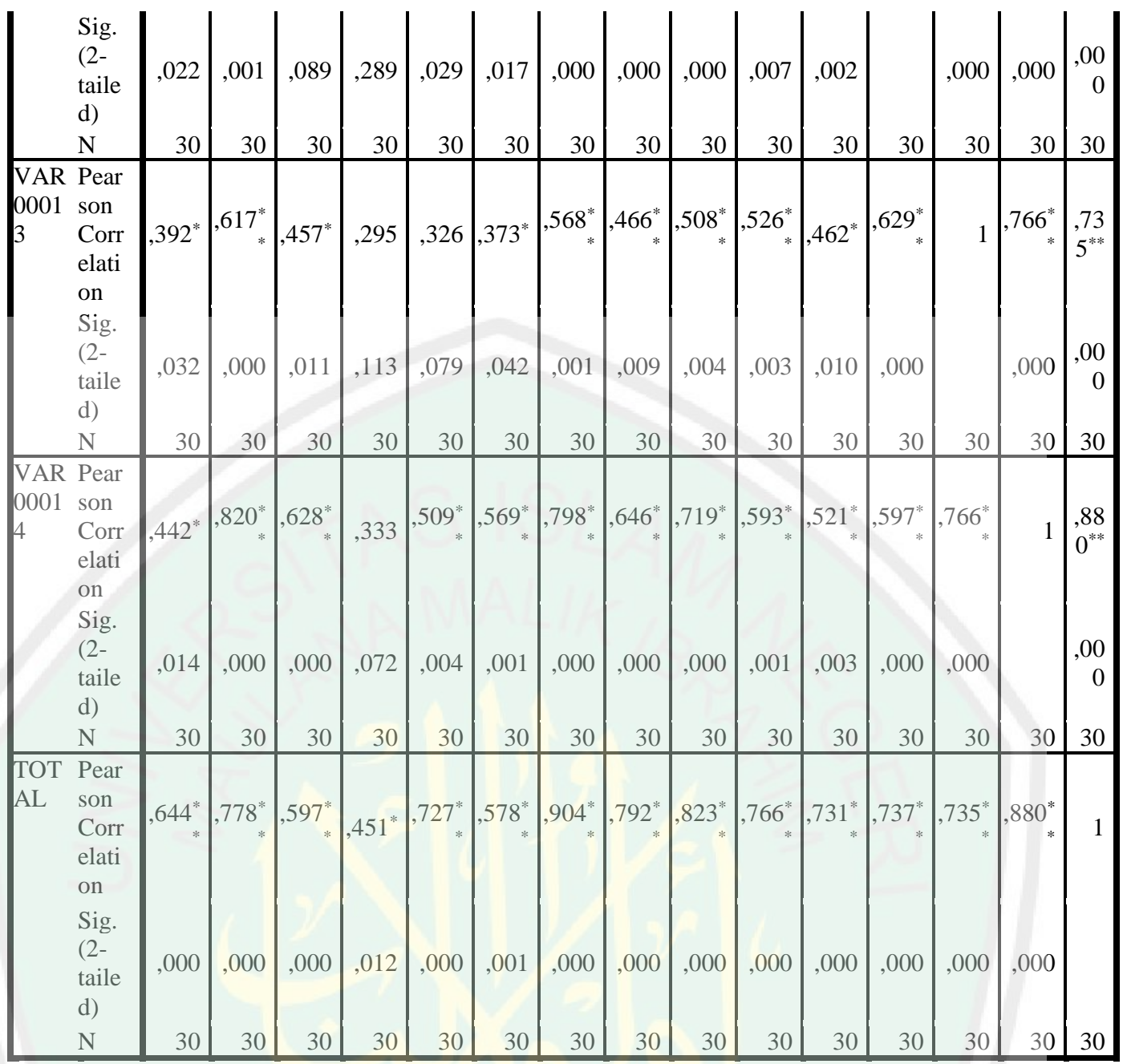

**. Correlation is significant at the 0.01 level (2-tailed).

*. Correlation is significant at the 0.05 level (2-tailed).

\section{Reliability}

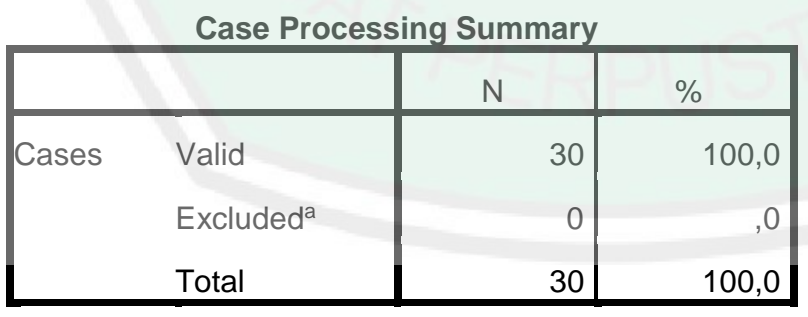

a. Listwise deletion based on all variables in the procedure.

Reliability Statistics

\begin{tabular}{|r|r|}
\hline Cronbach's Alpha & N of Items \\
\hline, 926 & 14 \\
\hline
\end{tabular}


Item-Total Statistics

\begin{tabular}{|l|r|r|r|r|}
\hline & $\begin{array}{r}\text { Scale Mean if Item } \\
\text { Deleted }\end{array}$ & $\begin{array}{c}\text { Scale Variance if } \\
\text { Item Deleted }\end{array}$ & $\begin{array}{c}\text { Corrected Item- } \\
\text { Total Correlation }\end{array}$ & $\begin{array}{c}\text { Cronbach's Alpha } \\
\text { if Item Deleted }\end{array}$ \\
\hline VAR00001 & 54,5333 & 25,085 &, 568 &, 924 \\
VAR00002 & 54,4667 &, 732 &, 918 \\
VAR00003 & 54,4667 & 24,740 &, 517 &, 926 \\
VAR00004 & 54,3667 & 25,499 &, 356 &, 931 \\
VAR00005 & 54,4667 & 26,516 &, 680 &, 920 \\
VAR00006 & 54,5000 & 25,499 &, 517 &, 925 \\
VAR00007 & 54,5333 & 26,397 &, 887 \\
VAR00008 & 54,4333 & 25,016 &, 747 &, 915 \\
VAR00009 & 54,3667 & 24,530 &, 792 &, 917 \\
VAR00010 & 54,4333 & 25,137 &, 917 \\
VAR00011 & 54,6667 & 25,151 &, 630 \\
VAR00012 & 54,5667 & 25,195 &, 919 \\
VAR00013 & 54,4333 & 24,599 &, 679 &, 920 \\
VAR00014 & 54,4333 & 24,875 &, 681 &, 920 \\
& & 24,530 &, 856 &, 920 \\
\hline
\end{tabular}


Lampiran 5: Data Penelitian

\begin{tabular}{|c|c|c|c|c|c|}
\hline LK1 & LK2 & LK3 & LK4 & LK5 & LK6 \\
\hline 5 & 5 & 1 & 5 & 4 & 5 \\
\hline 5 & 5 & 1 & 5 & 4 & 4 \\
\hline 5 & 5 & 1 & 5 & 5 & 5 \\
\hline 5 & 5 & 1 & 5 & 5 & 5 \\
\hline 5 & 5 & 1 & 4 & 4 & 5 \\
\hline 4 & 5 & -2 & 4 & 5 & 5 \\
\hline 5 & 5 & 5 & 5 & 5 & 5 \\
\hline 5 & 5 & 1 & 5 & 5 & 5 \\
\hline 5 & 4 & 1 & 4 & 5 & 5 \\
\hline 5 & 5 & 1 & 5 & 5 & 5 \\
\hline 5 & 5 & 1 & 4 & 5 & 5 \\
\hline 5 & 5 & 4 & 5 & 5 & 5 \\
\hline 4 & 5 & 4 & 4 & 5 & 5 \\
\hline 5 & 5 & 5 & 5 & 5 & 5 \\
\hline 5 & 5 & 4 & 5 & 5 & 4 \\
\hline 5 & 5 & 4 & 5 & 5 & 5 \\
\hline 5 & 5 & 4 & 5 & 5 & 5 \\
\hline 5 & 5 & 4 & 5 & 5 & 5 \\
\hline 5 & 5 & 4 & 5 & 5 & 5 \\
\hline 5 & 5 & 4 & 5 & 5 & 5 \\
\hline 5 & 5 & 4 & 5 & 5 & 5 \\
\hline 5 & 5 & 4 & 5 & 5 & 5 \\
\hline 5 & 5 & 4 & 5 & 5 & 5 \\
\hline 5 & 5 & 4 & 5 & 5 & 5 \\
\hline 5 & 5 & 4 & 5 & 5 & 5 \\
\hline 5 & 5 & 4 & 5 & 5 & 5 \\
\hline 5 & 5 & 5 & 5 & 5 & 5 \\
\hline 4 & 4 & 4 & 4 & 4 & 4 \\
\hline 5 & 5 & 5 & 4 & 5 & 5 \\
\hline 4 & 3 & 5 & 5 & 5 & 5 \\
\hline 4 & 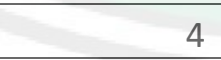 & 4 & 4 & 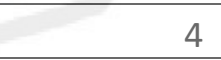 & 4 \\
\hline 4 & 4 & 4 & 4 & 4 & 4 \\
\hline 5 & 5 & 5 & 5 & 5 & 5 \\
\hline 5 & 5 & 5 & 5 & 5 & 5 \\
\hline 5 & 5 & 5 & 5 & 5 & 5 \\
\hline 4 & 3 & 5 & 3 & 5 & 5 \\
\hline 4 & 4 & 5 & 5 & 5 & 5 \\
\hline 4 & 4 & 5 & 4 & 5 & 5 \\
\hline 4 & 4 & 5 & 5 & 5 & 5 \\
\hline 5 & 4 & 4 & 4 & 5 & 5 \\
\hline
\end{tabular}




\begin{tabular}{|c|c|c|c|c|c|}
\hline 5 & 5 & 5 & 5 & 5 & 5 \\
\hline 4 & 4 & 4 & 4 & 4 & 4 \\
\hline 5 & 5 & 5 & 4 & 5 & 5 \\
\hline 4 & 3 & 5 & 5 & 5 & 5 \\
\hline 4 & 4 & 4 & 4 & 4 & 4 \\
\hline 4 & 4 & 4 & 4 & 4 & 4 \\
\hline 5 & 5 & 5 & 5 & 5 & 5 \\
\hline 5 & 5 & 5 & 5 & 5 & 5 \\
\hline 5 & 5 & 5 & 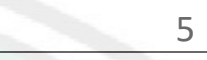 & 5 & 5 \\
\hline 4 & 3 & 5 & 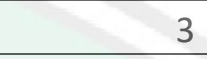 & 5 & 5 \\
\hline 4 & 4 & 5 & 5 & 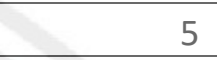 & 5 \\
\hline 4 & 4 & 5 & 4 & 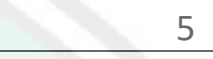 & 5 \\
\hline 4 & 4 & 5 & 5 & 5 & 5 \\
\hline 5 & 4 & 4 & 4 & 5 & 5 \\
\hline 5 & 5 & 5 & 5 & 5 & 5 \\
\hline 4 & 4 & 4 & 4 & 4 & 4 \\
\hline 5 & 5 & 5 & 4 & 5 & 5 \\
\hline 4 & 3 & 5 & 5 & 5 & 5 \\
\hline 4 & 4 & 4 & 4 & 4 & 4 \\
\hline 4 & 4 & 4 & 4 & 4 & 4 \\
\hline 5 & 5 & 5 & 5 & 5 & 5 \\
\hline 5 & 5 & 5 & 5 & 5 & 5 \\
\hline 5 & 5 & 5 & 5 & 5 & 5 \\
\hline 5 & 5 & 5 & 4 & 5 & 5 \\
\hline 4 & 5 & 4 & 3 & 5 & 5 \\
\hline 4 & 4 & 4 & 3 & 4 & 4 \\
\hline 5 & 5 & 4 & 3 & 5 & 5 \\
\hline 4 & 5 & 4 & 3 & 4 & 4 \\
\hline 5 & 5 & 5 & 5 & 5 & 5 \\
\hline 4 & 5 & 4 & 3 & 4 & 4 \\
\hline 4 & 5 & 4 & 3 & 4 & 4 \\
\hline 4 & 4 & 5 & 4 & 4 & 4 \\
\hline 5 & 5 & 5 & 3 & $\square$ & 5 \\
\hline 5 & 5 & 5 & 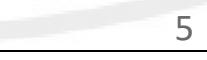 & 5 & 5 \\
\hline 4 & 5 & 4 & 4 & 4 & 4 \\
\hline 3 & 3 & 3 & 3 & 4 & 3 \\
\hline 5 & 5 & 5 & 4 & 5 & 5 \\
\hline 5 & 5 & 5 & 4 & 5 & 5 \\
\hline 5 & 5 & 5 & 4 & 5 & 5 \\
\hline 4 & 5 & 4 & 3 & 5 & 5 \\
\hline 4 & 4 & 4 & 3 & 4 & 4 \\
\hline 5 & 5 & 4 & 3 & 5 & 5 \\
\hline
\end{tabular}




\begin{tabular}{|r|r|r|r|r|r|}
\hline 4 & 5 & 4 & 3 & 4 & 4 \\
\hline 5 & 5 & 5 & 5 & 5 & 5 \\
\hline 4 & 5 & 4 & 3 & 4 & 4 \\
\hline 4 & 5 & 4 & 3 & 4 & 4 \\
\hline 4 & 4 & 5 & 4 & 4 & 4 \\
\hline 5 & 5 & 5 & 3 & 5 & 5 \\
\hline 5 & 5 & 5 & 5 & 5 & 5 \\
\hline 4 & 5 & 4 & 4 & 4 & 4 \\
\hline 3 & 3 & 3 & 3 & 4 & 3 \\
\hline 5 & 5 & 5 & 4 & 5 & 5 \\
\hline 4 & 4 & 4 & 4 & 4 & 4 \\
\hline 5 & 4 & 5 & 5 & 5 & 5 \\
\hline 4 & 3 & 4 & 4 & 5 & 5 \\
\hline 4 & 4 & 4 & 4 & 4 & 5 \\
\hline 5 & 4 & 5 & 4 & 4 & 4 \\
\hline 4 & 4 & 4 & 4 & 4 & 4 \\
\hline 5 & 4 & 4 & 4 & 4 & 3 \\
\hline 4 & 4 & 4 & 4 & 4 & 4 \\
\hline
\end{tabular}




\begin{tabular}{|c|c|c|c|c|c|c|c|c|c|}
\hline MK1 & MK2 & MK3 & MK4 & MK5 & MK6 & MK7 & MK8 & МК9 & MK 10 \\
\hline 4 & 3 & 4 & 4 & 4 & 5 & 4 & 5 & 5 & 5 \\
\hline 4 & 3 & 4 & 4 & 4 & 5 & 4 & 5 & 5 & 5 \\
\hline 4 & 2 & 4 & 4 & 4 & 5 & 4 & 5 & 5 & 5 \\
\hline 4 & 2 & 5 & 4 & 4 & 4 & 4 & 5 & 4 & 5 \\
\hline 5 & 1 & 4 & 4 & 4 & 5 & 5 & 5 & 5 & 5 \\
\hline 4 & 4 & 4 & 4 & 4 & 5 & 4 & 5 & 5 & 5 \\
\hline 5 & 5 & 5 & 5 & 5 & 5 & 3 & 2 & 5 & 5 \\
\hline 5 & 4 & 4 & 5 & 4 & 5 & 4 & 5 & 5 & 5 \\
\hline 4 & 3 & 4 & 4 & 3 & 4 & 4 & 4 & 5 & 5 \\
\hline 5 & 4 & 4 & 3 & 3 & 5 & 4 & 5 & 5 & 5 \\
\hline 4 & 3 & 4 & 4 & 3 & 4 & 4 & 5 & 5 & 5 \\
\hline 5 & 4 & 4 & 5 & 4 & 5 & 4 & 3 & 5 & 5 \\
\hline 4 & 4 & 4 & 4 & 4 & 5 & 4 & 5 & 5 & 5 \\
\hline 5 & 5 & 5 & 5 & 5 & 5 & 3 & 2 & 5 & 5 \\
\hline 5 & 5 & 5 & 5 & 5 & 5 & 4 & 5 & 5 & 4 \\
\hline 5 & 5 & 4 & 5 & 4 & 5 & 4 & 5 & 5 & 5 \\
\hline 5 & 5 & 4 & 5 & 4 & 5 & 4 & 5 & 5 & 5 \\
\hline 5 & 5 & 4 & 5 & 4 & 5 & 4 & 5 & 5 & 5 \\
\hline 5 & 4 & 5 & 4 & 5 & 5 & 4 & 5 & 5 & 5 \\
\hline 5 & 5 & 5 & 4 & 5 & 5 & 4 & 5 & 5 & 4 \\
\hline 5 & 5 & 4 & 5 & 4 & 5 & 4 & 5 & 5 & 5 \\
\hline 5 & 5 & 5 & 5 & 4 & 5 & 5 & 5 & 5 & 4 \\
\hline 5 & 4 & 5 & 5 & 4 & 5 & 4 & 5 & 5 & 5 \\
\hline 5 & 4 & 4 & 5 & 4 & 5 & 4 & 5 & 5 & 4 \\
\hline 5 & 5 & 4 & 5 & 4 & 5 & 4 & 5 & 5 & 5 \\
\hline 5 & 4 & 5 & 5 & 5 & 5 & 4 & 5 & 5 & 4 \\
\hline 5 & 5 & 4 & 5 & 5 & 5 & 5 & 5 & 5 & 5 \\
\hline 4 & 4 & 4 & 4 & 4 & 5 & 4 & 5 & 5 & 5 \\
\hline 4 & 5 & 4 & 4 & 5 & 5 & 5 & 5 & 5 & 5 \\
\hline 5 & 4 & 4 & 4 & 4 & 5 & 4 & 4 & 5 & 4 \\
\hline 4 & 3 & 4 & 4 & 3 & 4 & 3 & 4 & 4 & 4 \\
\hline 4 & 4 & 3 & 4 & 3 & 4 & 3 & 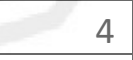 & 4 & 4 \\
\hline 4 & 4 & 5 & 5 & 4 & 4 & 4 & 5 & 5 & 5 \\
\hline 5 & 5 & 5 & 5 & 5 & 5 & 5 & 5 & 5 & 5 \\
\hline 5 & 4 & 5 & 5 & 5 & 5 & 5 & 5 & 5 & 5 \\
\hline 5 & 4 & 4 & 5 & 4 & 5 & 4 & 4 & 5 & 5 \\
\hline 5 & 4 & 4 & 4 & 3 & 4 & 4 & 4 & 5 & 5 \\
\hline 4 & 4 & 4 & 4 & 4 & 4 & 5 & 5 & 5 & 4 \\
\hline 5 & 4 & 4 & 4 & 4 & 5 & 4 & 5 & 5 & 5 \\
\hline 5 & 5 & 5 & 5 & 5 & 5 & 5 & 5 & 5 & 4 \\
\hline 5 & 5 & 4 & 5 & 5 & 5 & 5 & 5 & 5 & 5 \\
\hline
\end{tabular}




\begin{tabular}{|c|c|c|c|c|c|c|c|c|c|}
\hline 4 & 4 & 4 & 4 & 4 & 5 & 4 & 5 & 5 & 5 \\
\hline 4 & 5 & 4 & 4 & 5 & 5 & 5 & 5 & 5 & 5 \\
\hline 5 & 4 & 4 & 4 & 4 & 5 & 4 & 4 & 5 & 4 \\
\hline 4 & 3 & 4 & 4 & 3 & 4 & 3 & 4 & 4 & 4 \\
\hline 4 & 4 & 3 & 4 & 3 & 4 & 3 & 4 & 4 & 4 \\
\hline 4 & 4 & 5 & 5 & 4 & 4 & 4 & 5 & 5 & 5 \\
\hline 5 & 5 & 5 & 5 & 5 & 5 & 5 & 5 & 5 & 5 \\
\hline 5 & 4 & 5 & 5 & 5 & 5 & 5 & 5 & 5 & 5 \\
\hline 5 & 4 & 4 & 5 & 4 & 5 & 4 & 4 & 5 & 5 \\
\hline 5 & 4 & 4 & 4 & 3 & 4 & 4 & 4 & 5 & 5 \\
\hline 4 & 4 & 4 & 4 & 4 & 4 & 5 & 5 & 5 & 4 \\
\hline 5 & 4 & 4 & 4 & 4 & 5 & 4 & 5 & 5 & 5 \\
\hline 5 & 5 & 5 & 5 & 5 & 5 & 5 & 5 & 5 & 4 \\
\hline 5 & 5 & 4 & 5 & 5 & 5 & 5 & 5 & 5 & 5 \\
\hline 4 & 4 & 4 & 4 & 4 & 5 & 4 & 5 & 5 & 5 \\
\hline 4 & 5 & 4 & 4 & 5 & 5 & 5 & 5 & 5 & 5 \\
\hline 5 & 4 & 4 & 4 & 4 & 5 & 4 & 4 & 5 & 4 \\
\hline 4 & 3 & 4 & 4 & 3 & 4 & 3 & 4 & 4 & 4 \\
\hline 4 & 4 & 3 & 4 & 3 & 4 & 3 & 4 & 4 & 4 \\
\hline 4 & 4 & 5 & 5 & 4 & 4 & 4 & 5 & 5 & 5 \\
\hline 5 & 5 & 5 & 5 & 5 & 5 & 5 & 5 & 5 & 5 \\
\hline 5 & 4 & 5 & 5 & 5 & 5 & 5 & 5 & 5 & 5 \\
\hline 5 & 5 & 5 & 5 & 5 & 5 & 5 & 5 & 5 & 5 \\
\hline 5 & 5 & 5 & 5 & 5 & 5 & 5 & 5 & 5 & 4 \\
\hline 4 & 4 & 4 & 4 & 4 & 4 & 4 & 4 & 4 & 4 \\
\hline 4 & 4 & 4 & 4 & 4 & 4 & 4 & 4 & 4 & 4 \\
\hline 4 & 4 & 4 & 4 & 4 & 4 & 4 & 4 & 4 & 4 \\
\hline 5 & 5 & 5 & 5 & 5 & 5 & 5 & 5 & 5 & 5 \\
\hline 4 & 4 & 4 & 4 & 4 & 4 & 4 & 4 & 4 & 4 \\
\hline 5 & 5 & 5 & 5 & 5 & 5 & 5 & 5 & 5 & 5 \\
\hline 5 & 5 & 5 & 5 & 5 & 5 & 5 & 5 & 5 & 5 \\
\hline 5 & 5 & 3 & 5 & 5 & 5 & 5 & 5 & 5 & 5 \\
\hline 5 & 5 & 5 & 5 & 5 & 5 & 5 & 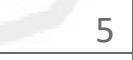 & 5 & 5 \\
\hline 5 & 5 & 5 & 5 & 5 & 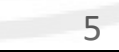 & 5 & 5 & 5 & 5 \\
\hline 4 & 4 & 4 & 4 & 4 & 4 & 4 & 4 & 4 & 4 \\
\hline 5 & 5 & 5 & 5 & 5 & 5 & 5 & 5 & 5 & 5 \\
\hline 5 & 5 & 5 & 5 & 5 & 5 & 5 & 5 & 5 & 5 \\
\hline 5 & 5 & 5 & 5 & 5 & 5 & 5 & 5 & 5 & 5 \\
\hline 5 & 5 & 5 & 5 & 5 & 5 & 5 & 5 & 5 & 4 \\
\hline 4 & 4 & 4 & 4 & 4 & 4 & 4 & 4 & 4 & 4 \\
\hline 4 & 4 & 4 & 4 & 4 & 4 & 4 & 4 & 4 & 4 \\
\hline 4 & 4 & 4 & 4 & 4 & 4 & 4 & 4 & 4 & 4 \\
\hline
\end{tabular}




\begin{tabular}{|r|r|r|r|r|r|r|r|r|r|}
\hline 5 & 5 & 5 & 5 & 5 & 5 & 5 & 5 & 5 & 5 \\
\hline 4 & 4 & 4 & 4 & 4 & 4 & 4 & 4 & 4 & 4 \\
\hline 5 & 5 & 5 & 5 & 5 & 5 & 5 & 5 & 5 & 5 \\
\hline 5 & 5 & 5 & 5 & 5 & 5 & 5 & 5 & 5 & 5 \\
\hline 5 & 5 & 3 & 5 & 5 & 5 & 5 & 5 & 5 & 5 \\
\hline 5 & 5 & 5 & 5 & 5 & 5 & 5 & 5 & 5 & 5 \\
\hline 5 & 5 & 5 & 5 & 5 & 5 & 5 & 5 & 5 & 5 \\
\hline 4 & 4 & 4 & 4 & 4 & 4 & 4 & 4 & 4 & 4 \\
\hline 5 & 5 & 5 & 5 & 5 & 5 & 5 & 5 & 5 & 5 \\
\hline 5 & 5 & 4 & 5 & 4 & 5 & 4 & 5 & 5 & 4 \\
\hline 5 & 5 & 5 & 5 & 4 & 5 & 4 & 5 & 5 & 5 \\
\hline 4 & 4 & 3 & 5 & 3 & 4 & 4 & 4 & 5 & 5 \\
\hline 5 & 5 & 5 & 5 & 4 & 5 & 5 & 4 & 5 & 5 \\
\hline 4 & 3 & 3 & 4 & 3 & 4 & 3 & 4 & 5 & 4 \\
\hline 4 & 4 & 4 & 4 & 4 & 4 & 4 & 4 & 4 & 4 \\
\hline 4 & 4 & 4 & 4 & 4 & 4 & 4 & 4 & 4 & 4 \\
\hline 4 & 4 & 4 & 3 & 3 & 4 & 4 & 5 & 4 & 4 \\
\hline
\end{tabular}




\begin{tabular}{|c|c|c|c|}
\hline KK1 & KK2 & KK3 & KK4 \\
\hline 5 & 4 & 3 & 5 \\
\hline 5 & 4 & 3 & 5 \\
\hline 5 & 4 & 1 & 5 \\
\hline 5 & 4 & 1 & 4 \\
\hline 5 & 4 & 1 & 4 \\
\hline 5 & 4 & 4 & 5 \\
\hline 5 & 5 & 3 & 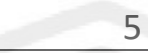 \\
\hline 5 & 4 & 3 & 5 \\
\hline 5 & 4 & 3 & 4 \\
\hline 5 & 5 & 3 & 4 \\
\hline 5 & 4 & 3 & 4 \\
\hline 4 & 4 & 4 & 4 \\
\hline 5 & 4 & 4 & 5 \\
\hline 5 & 5 & 3 & 5 \\
\hline 4 & 5 & 4 & 5 \\
\hline 4 & 5 & 4 & 5 \\
\hline 4 & 5 & 4 & 5 \\
\hline 4 & 5 & 4 & 5 \\
\hline 4 & 5 & 4 & 5 \\
\hline 4 & 5 & 4 & 5 \\
\hline 4 & 5 & 4 & 5 \\
\hline 4 & 5 & 4 & 5 \\
\hline 4 & 5 & 4 & 5 \\
\hline 4 & 5 & 4 & 5 \\
\hline 4 & 5 & 4 & 5 \\
\hline 4 & 5 & 4 & 5 \\
\hline 5 & 5 & 3 & 5 \\
\hline 5 & 5 & 4 & 5 \\
\hline 5 & 5 & 4 & 5 \\
\hline 4 & 4 & 4 & 4 \\
\hline 4 & 4 & 3 & 4 \\
\hline 4 & 4 & 3 & 4 \\
\hline 5 & 4 & wan & 5 \\
\hline 5 & 5 & 5 & 5 \\
\hline 5 & 5 & 5 & 5 \\
\hline 5 & 5 & 3 & 4 \\
\hline 5 & 4 & 3 & 4 \\
\hline 4 & 4 & 3 & 4 \\
\hline 5 & 4 & 4 & 4 \\
\hline 4 & 5 & 5 & 5 \\
\hline 5 & 5 & 3 & 5 \\
\hline
\end{tabular}




\begin{tabular}{|c|c|c|c|}
\hline 5 & 5 & 4 & 5 \\
\hline 5 & 5 & 4 & 5 \\
\hline 4 & 4 & 4 & 4 \\
\hline 4 & 4 & 3 & 4 \\
\hline 4 & 4 & 3 & 4 \\
\hline 5 & 4 & 4 & 5 \\
\hline 5 & 5 & 5 & 5 \\
\hline 5 & 5 & 5 & 5 \\
\hline 5 & 5 & 3 & 4 \\
\hline 5 & 4 & 3 & 4 \\
\hline 4 & 4 & 3 & 4 \\
\hline 5 & 4 & 4 & 4 \\
\hline 4 & 5 & 5 & 5 \\
\hline 5 & 5 & 3 & 5 \\
\hline 5 & 5 & 4 & 5 \\
\hline 5 & 5 & 4 & 5 \\
\hline 4 & 4 & 4 & 4 \\
\hline 4 & 4 & 3 & 4 \\
\hline 4 & 4 & 3 & 4 \\
\hline 5 & 4 & 4 & 5 \\
\hline 5 & 5 & 5 & 5 \\
\hline 5 & 5 & 5 & 5 \\
\hline 5 & 5 & 5 & 4 \\
\hline 5 & 5 & 5 & 3 \\
\hline 4 & 4 & 4 & 3 \\
\hline 4 & 4 & 4 & 3 \\
\hline 5 & 4 & 4 & 3 \\
\hline 5 & 5 & 5 & 3 \\
\hline 5 & 4 & 4 & 3 \\
\hline 5 & 5 & 5 & 4 \\
\hline 5 & 5 & 5 & 4 \\
\hline 5 & 5 & 5 & 3 \\
\hline 5 & 5 & 5 & 4 \\
\hline 5 & 5 & 5 & 4 \\
\hline 4 & 4 & 4 & 3 \\
\hline 5 & 5 & 5 & 2 \\
\hline 5 & 5 & 5 & 2 \\
\hline 5 & 5 & 5 & 4 \\
\hline 5 & 5 & 5 & 3 \\
\hline 4 & 4 & 4 & 3 \\
\hline 4 & 4 & 4 & 3 \\
\hline 5 & 4 & 4 & 3 \\
\hline
\end{tabular}




\begin{tabular}{|r|r|r|r|}
\hline 5 & 5 & 5 & 3 \\
\hline 5 & 4 & 4 & 3 \\
\hline 5 & 5 & 5 & 4 \\
\hline 5 & 5 & 5 & 4 \\
\hline 5 & 5 & 5 & 3 \\
\hline 5 & 5 & 5 & 4 \\
\hline 5 & 5 & 5 & 4 \\
\hline 4 & 4 & 4 & 3 \\
\hline 5 & 5 & 5 & 2 \\
\hline 4 & 4 & 4 & 4 \\
\hline 5 & 5 & 5 & 5 \\
\hline 5 & 4 & 3 & 4 \\
\hline 5 & 5 & 5 & 5 \\
\hline 4 & 3 & 3 & 4 \\
\hline 4 & 4 & 4 & 4 \\
\hline 4 & 4 & 4 & 5 \\
\hline 5 & 3 & 2 & 5 \\
\hline
\end{tabular}




\begin{tabular}{|c|c|c|c|c|c|c|c|c|c|c|c|c|c|}
\hline $\begin{array}{l}\text { KG } \\
1 \\
\end{array}$ & $\begin{array}{l}\text { KG } \\
2\end{array}$ & $\begin{array}{l}\text { KG } \\
3\end{array}$ & $\begin{array}{l}\text { KG } \\
4 \\
\end{array}$ & $\begin{array}{l}\text { KG } \\
5 \\
\end{array}$ & $\begin{array}{l}\text { KG } \\
6 \\
\end{array}$ & $\begin{array}{l}\text { KG } \\
7 \\
\end{array}$ & \begin{tabular}{|l|}
$K G$ \\
8 \\
\end{tabular} & $\begin{array}{l}\text { KG } \\
9 \\
\end{array}$ & $\begin{array}{l}\text { KG1 } \\
0\end{array}$ & \begin{tabular}{|l|} 
KG1 \\
1 \\
\end{tabular} & $\begin{array}{l}\text { KG1 } \\
2\end{array}$ & $\begin{array}{l}\text { KG1 } \\
3 \\
\end{array}$ & $\begin{array}{l}\text { KG1 } \\
4 \\
\end{array}$ \\
\hline 5 & 5 & 4 & 4 & 5 & 5 & 5 & 5 & 4 & 5 & 4 & 5 & 4 & 4 \\
\hline 5 & 4 & 5 & 4 & 5 & 5 & 4 & 4 & 4 & 5 & 4 & 4 & 5 & 4 \\
\hline 4 & 4 & 5 & 5 & 5 & 5 & 4 & 4 & 4 & 5 & 4 & 5 & 4 & 4 \\
\hline 5 & 4 & 4 & 4 & 5 & 5 & 5 & 4 & 4 & 5 & 4 & 4 & 5 & 4 \\
\hline 4 & 4 & 5 & 5 & 5 & 5 & 5 & 4 & 4 & 5 & 4 & 4 & 4 & 4 \\
\hline 4 & 4 & 4 & 4 & 4 & 4 & 4 & 4 & 5 & 5 & 5 & 5 & 5 & 5 \\
\hline 5 & 4 & 5 & 5 & 5 & 5 & 5 & 5 & 5 & 5 & 5 & 5 & 5 & 5 \\
\hline 4 & 4 & 4 & 4 & 5 & 5 & 4 & 4 & 4 & 5 & 4 & 5 & 4 & 4 \\
\hline 4 & 4 & 5 & 5 & 5 & 5 & 4 & 4 & 4 & 5 & 4 & 4 & 4 & 4 \\
\hline 4 & 4 & 5 & 4 & 4 & 5 & 4 & 4 & 4 & 5 & 4 & 4 & 4 & 4 \\
\hline 4 & 4 & 4 & 4 & 5 & 5 & 4 & 4 & 4 & 5 & 4 & 4 & 4 & 4 \\
\hline 4 & 5 & 4 & 5 & 5 & 4 & 5 & 5 & 4 & 4 & 5 & 5 & 5 & 5 \\
\hline 4 & 4 & 4 & 4 & 4 & 4 & 4 & 4 & 5 & 5 & 5 & 5 & 5 & 5 \\
\hline 5 & 4 & 5 & 5 & 5 & 5 & 5 & 5 & 5 & 5 & 5 & 5 & 5 & 5 \\
\hline 5 & 5 & 5 & 5 & 5 & 5 & 5 & 4 & 5 & 5 & 5 & 4 & 5 & 5 \\
\hline 5 & 5 & 5 & 5 & 5 & 5 & 5 & 4 & 5 & 5 & 5 & 4 & 5 & 5 \\
\hline 5 & 5 & 5 & 5 & 5 & 5 & 5 & 4 & 5 & 5 & 5 & 4 & 5 & 5 \\
\hline 5 & 5 & 5 & 5 & 5 & 5 & 5 & 4 & 5 & 5 & 5 & 4 & 5 & 5 \\
\hline 5 & 5 & 5 & 5 & 5 & 5 & 5 & 5 & 5 & 5 & 5 & 4 & 5 & 5 \\
\hline 5 & 5 & 5 & 5 & 5 & 5 & 5 & 4 & 5 & 5 & 4 & 5 & 5 & 5 \\
\hline 5 & 5 & 5 & 5 & 5 & 5 & 4 & 5 & 5 & 5 & 5 & 4 & 5 & 5 \\
\hline 5 & 5 & 5 & 5 & 5 & 5 & 5 & 4 & 5 & 5 & 5 & 4 & 5 & 5 \\
\hline 5 & 5 & 5 & 5 & 5 & 5 & 5 & 4 & 5 & 5 & 5 & 4 & 5 & 5 \\
\hline 5 & 5 & 5 & 5 & 5 & 5 & 5 & 5 & 4 & 5 & 5 & 4 & 5 & 5 \\
\hline 5 & 5 & 5 & 5 & 5 & 5 & 5 & 4 & 5 & 5 & 5 & 4 & 5 & 5 \\
\hline 4 & 5 & 5 & 5 & 5 & 5 & 5 & 4 & 4 & 5 & 4 & 5 & 5 & 5 \\
\hline 5 & 5 & 5 & 5 & 5 & 5 & 5 & 5 & 5 & 5 & 5 & 4 & 4 & 4 \\
\hline 4 & 5 & 5 & 5 & 4 & 4 & 5 & 4 & 5 & 5 & 4 & 5 & 5 & 4 \\
\hline 5 & 5 & 5 & 5 & 5 & 5 & 5 & 5 & 5 & 5 & 5 & 5 & 5 & 5 \\
\hline 4 & 4 & 4 & 4 & 4 & 4 & 4 & 4 & 4 & 4 & 4 & 4 & 4 & 4 \\
\hline 4 & 4 & 4 & 4 & 4 & 4 & 4 & 4 & 4 & 4 & 4 & 4 & 4 & 4 \\
\hline 4 & 4 & 4 & 4 & 4 & 4 & 4 & 4 & 4 & 4 & 4 & 4 & 4 & 4 \\
\hline 5 & 4 & 5 & 5 & 5 & 4 & 4 & 5 & 5 & 5 & 4 & 5 & 5 & 5 \\
\hline 4 & 5 & 5 & 5 & 4 & 5 & 5 & 5 & 4 & 5 & 5 & 5 & 4 & 4 \\
\hline 4 & 5 & 5 & 5 & 4 & 5 & 5 & 5 & 4 & 5 & 5 & 5 & 4 & 4 \\
\hline 5 & 5 & 5 & 5 & 5 & 5 & 4 & 4 & 4 & 5 & 5 & 4 & 4 & 4 \\
\hline 4 & 4 & 4 & 4 & 5 & 4 & 4 & 4 & 4 & 4 & 5 & 4 & 4 & 4 \\
\hline 4 & 4 & 4 & 4 & 4 & 4 & 4 & 4 & 4 & 4 & 4 & 4 & 3 & 4 \\
\hline 4 & 4 & 4 & 4 & 4 & 4 & 4 & 4 & 4 & 4 & 4 & 4 & 4 & 4 \\
\hline 4 & 4 & 5 & 5 & 5 & 5 & 5 & 5 & 5 & 5 & 5 & 5 & 4 & 4 \\
\hline
\end{tabular}




\begin{tabular}{|c|c|c|c|c|c|c|c|c|c|c|c|c|c|}
\hline 5 & 5 & 5 & 5 & 5 & 5 & 5 & 5 & 5 & 5 & 5 & 4 & 4 & 4 \\
\hline 4 & 5 & 5 & 5 & 4 & 4 & 5 & 4 & 5 & 5 & 4 & 5 & 5 & 4 \\
\hline 5 & 5 & 5 & 5 & 5 & 5 & 5 & 5 & 5 & 5 & 5 & 5 & 5 & 5 \\
\hline 4 & 4 & 4 & 4 & 4 & 4 & 4 & 4 & 4 & 4 & 4 & 4 & 4 & 4 \\
\hline 4 & 4 & 4 & 4 & 4 & 4 & 4 & 4 & 4 & 4 & 4 & 4 & 4 & 4 \\
\hline 4 & 4 & 4 & 4 & 4 & 4 & 4 & 4 & 4 & 4 & 4 & 4 & 4 & 4 \\
\hline 5 & 4 & 5 & 5 & 5 & 4 & 4 & 5 & 5 & 5 & 4 & 5 & 5 & 5 \\
\hline 4 & 5 & 5 & 5 & 4 & 5 & 5 & 5 & 4 & 5 & 5 & 5 & 4 & 4 \\
\hline 4 & 5 & 5 & 5 & 4 & 5 & 5 & 5 & 4 & 5 & 5 & 5 & 4 & 4 \\
\hline 5 & 5 & 5 & 5 & 5 & 5 & 4 & 4 & 4 & 5 & 5 & 4 & 4 & 4 \\
\hline 4 & 4 & 4 & 4 & 5 & 4 & 4 & 4 & 4 & 4 & 5 & 4 & 4 & 4 \\
\hline 4 & 4 & 4 & 4 & 4 & 4 & 4 & 4 & 4 & 4 & 4 & 4 & 3 & 4 \\
\hline 4 & 4 & 4 & 4 & 4 & 4 & 4 & 4 & 4 & 4 & 4 & 4 & 4 & 4 \\
\hline 4 & 4 & 5 & 5 & 5 & 5 & 5 & 5 & 5 & 5 & 5 & 5 & 4 & 4 \\
\hline 5 & 5 & 5 & 5 & 5 & 5 & 5 & 5 & 5 & 5 & 5 & 4 & 4 & 4 \\
\hline 4 & 5 & 5 & 5 & 4 & 4 & 5 & 4 & 5 & 5 & 4 & 5 & 5 & 4 \\
\hline 5 & 5 & 5 & 5 & 5 & 5 & 5 & 5 & 5 & 5 & 5 & 5 & 5 & 5 \\
\hline 4 & 4 & 4 & 4 & 4 & 4 & 4 & 4 & 4 & 4 & 4 & 4 & 4 & 4 \\
\hline 4 & 4 & 4 & 4 & 4 & 4 & 4 & 4 & 4 & 4 & 4 & 4 & 4 & 4 \\
\hline 4 & 4 & 4 & 4 & 4 & 4 & 4 & 4 & 4 & 4 & 4 & 4 & 4 & 4 \\
\hline 5 & 4 & 5 & 5 & 5 & 4 & 4 & 5 & 5 & 5 & 4 & 5 & 5 & 5 \\
\hline 4 & 5 & 5 & 5 & 4 & 5 & 5 & 5 & 4 & 5 & 5 & 5 & 4 & 4 \\
\hline 4 & 5 & 5 & 5 & 4 & 5 & 5 & 5 & 4 & 5 & 5 & 5 & 4 & 4 \\
\hline 4 & 4 & 4 & 4 & 4 & 4 & 4 & 4 & 4 & 4 & 4 & 4 & 4 & 4 \\
\hline 3 & 4 & 4 & 4 & 4 & 4 & 4 & 4 & 4 & 4 & 4 & 4 & 4 & 4 \\
\hline 3 & 4 & 4 & 4 & 4 & 4 & 4 & 4 & 4 & 4 & 3 & 4 & 3 & 4 \\
\hline 3 & 3 & 3 & 4 & 4 & 3 & 4 & 3 & 4 & 4 & 4 & 4 & 4 & 4 \\
\hline 3 & 3 & 4 & 4 & 3 & 4 & 3 & 4 & 4 & 4 & 4 & 4 & 4 & 4 \\
\hline 3 & 3 & 3 & 3 & 3 & 5 & 3 & 3 & 4 & 4 & 3 & 3 & 3 & 3 \\
\hline 3 & 3 & 3 & 3 & 3 & 5 & 3 & 3 & 4 & 5 & 4 & 4 & 4 & 4 \\
\hline 3 & 3 & 3 & 3 & 4 & 4 & 4 & 3 & 4 & 5 & 5 & 4 & 4 & 4 \\
\hline 4 & 4 & 4 & 4 & 5 & 4 & 4 & 5 & 5 & 5 & 5 & 5 & 5 & 5 \\
\hline 3 & 3 & 3 & 3 & 3 & 5 & 4 & 4 & 4 & 4 & 4 & 4 & 4 & 4 \\
\hline 4 & 4 & 4 & 4 & 4 & 5 & 4 & 5 & 5 & 5 & 4 & 4 & 4 & 4 \\
\hline 3 & 3 & 3 & 4 & 3 & 5 & 3 & 4 & 5 & 5 & 3 & 4 & 4 & 4 \\
\hline 3 & 3 & 4 & 3 & 3 & 4 & 3 & 3 & 4 & 4 & 3 & 3 & 3 & 3 \\
\hline 1 & 3 & 4 & 5 & 3 & 5 & 4 & 4 & 5 & 5 & 2 & 4 & 4 & 4 \\
\hline 2 & 3 & 4 & 4 & 3 & 4 & 3 & 4 & 4 & 4 & 4 & 4 & 4 & 4 \\
\hline 4 & 4 & 4 & 4 & 4 & 4 & 4 & 4 & 4 & 4 & 4 & 4 & 4 & 4 \\
\hline 3 & 4 & 4 & 4 & 4 & 4 & 4 & 4 & 4 & 4 & 4 & 4 & 4 & 4 \\
\hline 3 & 4 & 4 & 4 & 4 & 4 & 4 & 4 & 4 & 4 & 3 & 4 & 3 & 4 \\
\hline 3 & 3 & 3 & 4 & 4 & 3 & 4 & 3 & 4 & 4 & 4 & 4 & 4 & \\
\hline
\end{tabular}




\begin{tabular}{|l|l|l|l|r|r|r|r|r|r|r|r|r|r|}
\hline 3 & 3 & 4 & 4 & 3 & 4 & 3 & 4 & 4 & 4 & 4 & 4 & 4 & 4 \\
\hline 3 & 3 & 3 & 3 & 3 & 5 & 3 & 3 & 4 & 4 & 3 & 3 & 3 & 3 \\
\hline 3 & 3 & 3 & 3 & 3 & 5 & 3 & 3 & 4 & 5 & 4 & 4 & 4 & 4 \\
\hline 3 & 3 & 3 & 3 & 4 & 4 & 4 & 3 & 4 & 5 & 5 & 4 & 4 & 4 \\
\hline 4 & 4 & 4 & 4 & 5 & 4 & 4 & 5 & 5 & 5 & 5 & 5 & 5 & 5 \\
\hline 3 & 3 & 3 & 3 & 3 & 5 & 4 & 4 & 4 & 4 & 4 & 4 & 4 & 4 \\
\hline 4 & 4 & 4 & 4 & 4 & 5 & 4 & 5 & 5 & 5 & 4 & 4 & 4 & 4 \\
\hline 3 & 3 & 3 & 4 & 3 & 5 & 3 & 4 & 5 & 5 & 3 & 4 & 4 & 4 \\
\hline 3 & 3 & 4 & 3 & 3 & 4 & 3 & 3 & 4 & 4 & 3 & 3 & 3 & 3 \\
\hline 1 & 3 & 4 & 5 & 3 & 5 & 4 & 4 & 5 & 5 & 2 & 4 & 4 & 4 \\
\hline 4 & 4 & 4 & 4 & 4 & 4 & 4 & 4 & 4 & 4 & 4 & 4 & 4 & 4 \\
\hline 5 & 5 & 5 & 5 & 5 & 5 & 5 & 5 & 5 & 5 & 5 & 5 & 5 & 5 \\
\hline 4 & 4 & 4 & 5 & 4 & 4 & 4 & 4 & 4 & 4 & 4 & 4 & 5 & 5 \\
\hline 5 & 5 & 5 & 5 & 5 & 4 & 4 & 4 & 5 & 4 & 4 & 4 & 5 & 5 \\
\hline 4 & 4 & 4 & 4 & 4 & 4 & 4 & 4 & 4 & 4 & 4 & 4 & 3 & 4 \\
\hline 4 & 4 & 4 & 4 & 4 & 4 & 4 & 4 & 4 & 4 & 4 & 4 & 4 & 4 \\
\hline 5 & 5 & 4 & 4 & 4 & 3 & 4 & 4 & 4 & 4 & 4 & 4 & 4 & 4 \\
\hline 4 & 4 & 4 & 5 & 4 & 4 & 4 & 4 & 4 & 5 & 4 & 4 & 5 & 4 \\
\hline
\end{tabular}




\section{Lampiran 6 Uji Normalitas}

Ik

\begin{tabular}{|c|c|c|c|c|c|}
\hline & & Frequency & Percent & Valid Percent & $\begin{array}{c}\text { Cumulative } \\
\text { Percent }\end{array}$ \\
\hline \multirow[t]{10}{*}{ Valid } & 19,00 & 2 & 2,0 & 2,0 & 2,0 \\
\hline & 23,00 & 2 & 2,0 & 2,0 & 4,0 \\
\hline & 24,00 & 22 & 22,0 & 22,0 & 26,0 \\
\hline & 25,00 & 10 & 10,0 & 10,0 & 36,0 \\
\hline & 26,00 & 7 & 7,0 & 7,0 & 43,0 \\
\hline & 27,00 & 11 & 11,0 & 11,0 & 54,0 \\
\hline & 28,00 & 7 & 7,0 & 7,0 & 61,0 \\
\hline & 29,00 & 21 & 21,0 & 21,0 & 82,0 \\
\hline & 30,00 & 18 & 18,0 & 18,0 & 100,0 \\
\hline & Total & 100 & 100,0 & 100,0 & \\
\hline
\end{tabular}

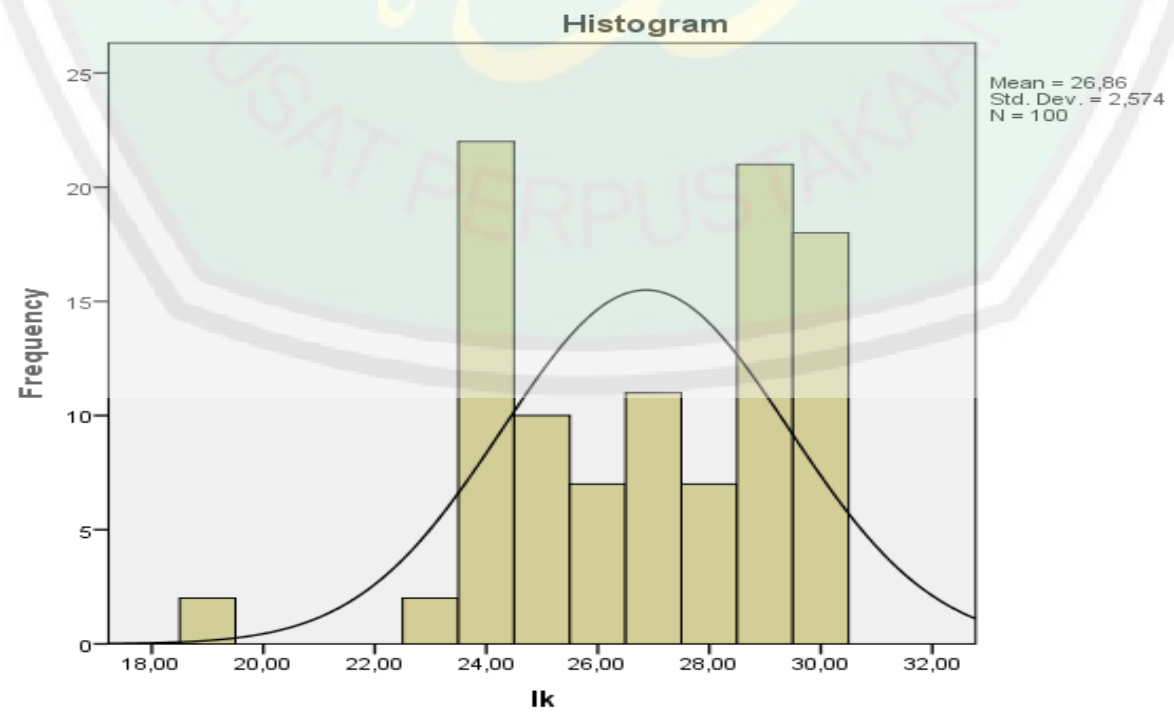


Tests of Normality

\begin{tabular}{|r|r|r|r|r|r|r|}
\hline \multicolumn{4}{|c|}{ Kolmogorov-Smirnov } & \multicolumn{3}{c|}{ Shapiro-Wilk } \\
\cline { 2 - 7 } & Statistic & df & \multicolumn{1}{|c|}{ Sig. } & Statistic & df & Sig. \\
\hline $\mathrm{kg}$ &, 149 & 100 &, 000 &, 942 & 100 &, 000 \\
\hline
\end{tabular}

\section{NPar Tests}

a. Based on availability of workspace memory.

One-Sample Kolmogorov-Smirnov Test

\begin{tabular}{|c|c|c|c|c|c|}
\hline & & Ik & $\mathrm{mk}$ & kk & $\mathrm{kg}$ \\
\hline N & & 100 & 100 & 100 & 100 \\
\hline \multirow[t]{2}{*}{ Normal Parameters ${ }^{a, b}$} & Mean & 26,8600 & 45,0200 & 17,3200 & 60,0300 \\
\hline & Std. Deviation & 2,57423 & 4,07004 & 1,64458 & 6,52339 \\
\hline \multirow[t]{3}{*}{ Most Extreme Differences } & Absolute & ,187 &, 147 & ,200 & , 149 \\
\hline & Positive & ,127 &, 111 & , 129 & ,142 \\
\hline & Negative &,- 187 &,- 147 &,- 200 &,- 149 \\
\hline Test Statistic & & ,187 & ,147 & 200 & 149 \\
\hline Asymp. Sig. (2-tailed) & &, $000^{c}$ &, $000^{c}$ &, $000^{c}$ &, $000^{\circ}$ \\
\hline
\end{tabular}
a. Test distribution is Normal.
b. Calculated from data. 
Lampiran 7 Uji Regresi Data Penelitian

Variables Entered/Removed ${ }^{a}$

\begin{tabular}{|l|l|l|l|}
\hline Model & \multicolumn{1}{|c|}{$\begin{array}{c}\text { Variables } \\
\text { Entered }\end{array}$} & $\begin{array}{c}\text { Variables } \\
\text { Removed }\end{array}$ & Method \\
\hline 1 & $\mathrm{X} 2, \mathrm{X} 1^{\mathrm{b}}$ & & Enter \\
\hline
\end{tabular}

Model Summary

\begin{tabular}{|r|r|r|r|c|}
\hline Model & $\mathrm{R}$ & $\mathrm{R}$ Square & \multicolumn{1}{c|}{$\begin{array}{c}\text { Adjusted } \mathrm{R} \\
\text { Square }\end{array}$} & $\begin{array}{c}\text { Std. Error of the } \\
\text { Estimate }\end{array}$ \\
\hline 1 &, $834^{\mathrm{a}}$ &, 695 &, 689 &, 91693 \\
\hline
\end{tabular}

a. Predictors: (Constant), X2, X1

ANOVA $^{a}$

\begin{tabular}{|r|r|r|r|r|r|}
\hline \multicolumn{1}{|l|}{ Model } & Sum of Squares & df & Mean Square & F & Sig. \\
\hline $1 \quad$ Regression & 186,207 & 2 & 93,103 & 110,738 &, $000^{\mathrm{b}}$ \\
Residual & 81,553 & 97 &, 841 & & \\
Total & 267,760 & 99 & & & \\
\hline
\end{tabular}

Coefficients $^{a}$

\begin{tabular}{|c|c|c|c|c|c|c|}
\hline \multirow[b]{2}{*}{ Mode } & & \multicolumn{2}{|c|}{ Unstandardized Coefficients } & \multirow{2}{*}{$\begin{array}{c}\begin{array}{c}\text { Standardized } \\
\text { Coefficients }\end{array} \\
\text { Beta }\end{array}$} & \multirow[b]{2}{*}{$\mathrm{t}$} & \multirow[b]{2}{*}{ Sig. } \\
\hline & & B & Std. Error & & & \\
\hline \multirow[t]{3}{*}{1} & (Constant) & 1,972 & 1,106 & & 1,783 & 078 \\
\hline & $\mathrm{X} 1$ &, 120 & ,04 & 0146 & 2,050 & ,043 \\
\hline & $\mathrm{X} 2$ & ,329 & ,029 & ,814 & 11,371 & ,000 \\
\hline
\end{tabular}

a. Dependent Variable: Z 


\section{Regression}

Model Summary

\begin{tabular}{|r|r|r|r|r|}
\hline Model & $\mathrm{R}$ & $\mathrm{R}$ Square & $\begin{array}{c}\text { Adjusted R } \\
\text { Square }\end{array}$ & $\begin{array}{c}\text { Std. Error of the } \\
\text { Estimate }\end{array}$ \\
\hline 1 &, $648^{\mathrm{a}}$ &, 421 &, 402 & 5,04277 \\
\hline
\end{tabular}

a. Predictors: (Constant), Z, X1, X2

ANOVA $^{a}$

\begin{tabular}{|c|c|c|c|c|c|c|}
\hline \multicolumn{2}{|c|}{ Model } & $\begin{array}{l}\text { Sum of } \\
\text { Squares }\end{array}$ & df & $\begin{array}{l}\text { Mean } \\
\text { Square }\end{array}$ & $\mathrm{F}$ & Sig. \\
\hline \multirow[t]{3}{*}{1} & Regression & 1771,675 & 3 & 590,558 & 23,223 &, $000^{b}$ \\
\hline & Residual & 2441,235 & 96 & 25,430 & & \\
\hline & Total & 4212,910 & 99 & & & \\
\hline
\end{tabular}

Dependent Variable: $Y$

b. Predictors: (Constant), Z, X1, X2

Coefficients $^{\mathrm{a}}$

\begin{tabular}{|c|c|c|c|c|c|c|}
\hline \multirow[b]{2}{*}{ Model } & & \multicolumn{2}{|c|}{ Unstandardized Coefficients } & \multirow{2}{*}{$\begin{array}{c}\text { Standardized } \\
\text { Coefficients } \\
\text { Beta }\end{array}$} & \multirow[b]{2}{*}{$\mathrm{t}$} & \multirow[b]{2}{*}{ Sig. } \\
\hline & & B & Std. Error & & & \\
\hline$(($ & (Constant) & 19,946 & 6,179 & & 3,228 & ,002 \\
\hline & $x 1$ & 1,213 & ,252 & ,479 & 4,820 &, 000 \\
\hline & $\mathrm{X} 2$ &,- 965 & ,243 &,- 602 & $-3,972$ & ,000 \\
\hline Z & Z & 2,941 &, 558 & ,741 & 5,266 & ,000 \\
\hline
\end{tabular}




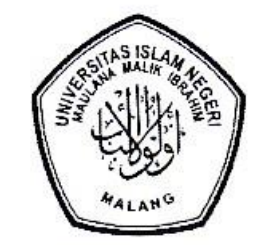

\section{KEMENTERIAN AGAMA REPUBLIK INDONESIA UNIVERSITAS ISLAM NEGERI MAULANA MALIK IBRAHIM MALANG PASCASARJANA}

Jalan Ir. Soekarno No. 34 Batu 65323, Telepon \& Faksimile (0341) 531133

Website: http://pasca.uin-malang.ac.id, Email: pps@uin-malang.ac.id

Nomor : B-029/Ps/HM.01/03/2018

07 Maret 2018

Hal : Permohonan Ijin Penelitian

Kepada

Yth. Kepala MA Hasan Jufri.

Di

Tempat

Assalamu'alaikum Wr.Wb

Berkenaan dengan tugas penulisan tesis bagi mahasiswa kami, maka dengan ini mohon kepada Bapak/Ibu untuk berkenan memberi ijin kepada mahasiswa di bawah ini melakukan penelitian pada lembaga yang Bapak/Ibu pimpin:
Nama
: Moh. Nasir
NIM
: 16710016
Program Studi
: Magister Manajemen Pendidikan Islam
Dosen Pembimbing
1. Dr. H. Munirul Abidin, M.Ag.
2. Dr. H. Abdul Basith, M.Si.
Judul Tesis
: Analisis Pengaruh Lingkungan Kerja dan Motivasi Kerja Terhadap Kepuasan Kerja Guru dan Dampaknya Pada Kinerja Guru Madrasah Aliyah di Pulau Bawean.

Demikian permohonan ini disampaikan, atas perkenan dan kerjasamanya disampaikan terima kasih

Wassalamu'alaikum $W r . W b$

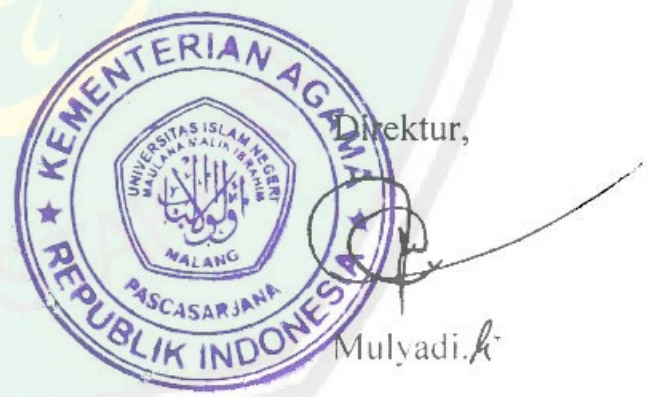




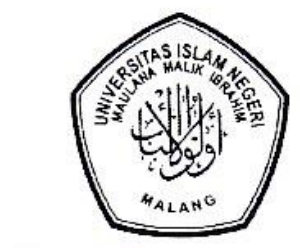

\section{KEMENTERIAN AGAMA REPUBLIK INDONESIA UNIVERSITAS ISLAM NEGERI MAULANA MALIK IBRAHIM MALANG PASCASARJANA}

Jalan Ir. Soekarno No. 34 Batu 65323, Telepon \& Faksimile (0341) 531133

Website: http://pasca.uin-malang.ac.id, Email: pps@uin-malang.ac.id

Nomor : B-029/Ps/HM.01/03/2018

07 Maret 2018

Hal : Permohonan Ijin Penelitian

Kepada

Yth. Kepala MA Miftahul Huda.

Di

Tempat

Assalamu'alaikum Wr.Wb

Berkenaan dengan tugas penulisan tesis bagi mahasiswa kami, maka dengan ini mohon kepada Bapak/Ibu untuk berkenan memberi ijin kepada mahasiswa di bawah ini melakukan penelitian pada lembaga yang Bapak/Ibu pimpin:

Nama

NIM

Moh. Nasir

Program Studi

16710016

Dosen Pembimbing

Magister Manajemen Pendidikan Islam

Judul Tesis

2. Dr. H. Abdul Basith, M.Si.

Analisis Pengaruh Lingkungan Kerja dan Motivasi Kerja Terhadap Kepuasan Kerja Guru dan Dampaknya Pada Kinerja

Guru Madrasah Aliyah di Pulau Bawean.

Demikian permohonan ini disampaikan, atas perkenan dan kerjasamanya disampaihan terima kasih

Wassalamu'alaikum Wr.Wb

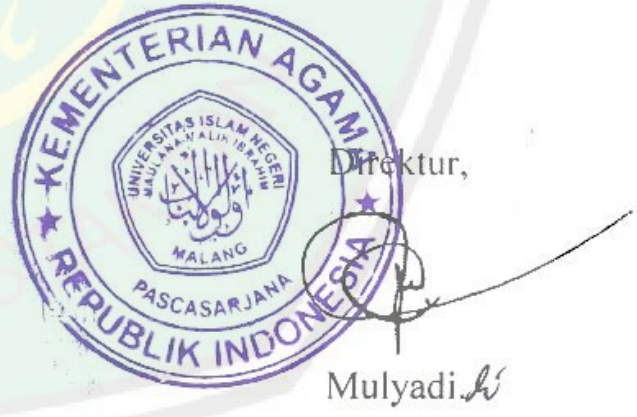




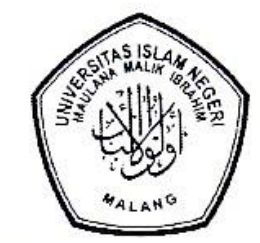

\section{KEMENTERIAN AGAMA REPUBLIK INDONESIA UNIVERSITAS ISLAM NEGERI MAULANA MALIK IBRAHIM MALANG PASCASARJANA}

Jalan Ir. Soekarno No. 34 Batu 65323, Telepon \& Faksimile (0341) 531133 Website: http://pasca.uin-malang.ac.id, Email: pps@uin-malang.ac.id

\section{Nomor : B-029/Ps/HM.01/03/2018 \\ Hal : Permohonan Ijin Penelitian}

07 Maret 2018

Kepada

Yth. Kepala MA Darussalam.

$\mathrm{Di}$

Tempat

\section{Assalamu'alaikum $\mathrm{Wr} . \mathrm{Wb}$}

Berkenaan dengan tugas penulisan tesis bagi mahasiswa kami, maka dengan ini mohon kepada Bapak/Ibu untuk berkenan memberi ijin kepada mahasiswa di bawah ini melakukan penelitian pada lembaga yang Bapak/Ibu pimpin:

Nama

Moh. Nasir

NIM 16710016

Program Studi

: Magister Manajemen Pendidikan Islam

Dosen Pembimbing

1. Dr. H. Munirul Abidin, M.Ag.

2. Dr. H. Abdul Basith, M.Si.

Judul Tesis

: Analisis Pengaruh Lingkungan Kerja dan Motivasi Kerja Terhadap Kepuasan Kerja Guru dan Dampaknya Pada Kinerja Guru Madrasah Aliyah di Pulau Bawean.

Demikian permohonan ini disampaikan, atas perkenan dan kerjasamanya disampaikan terima kasih

Wassalamu'alaikum $W r . W b$

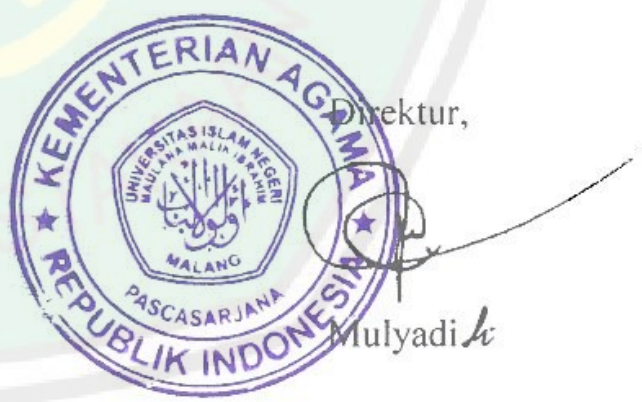




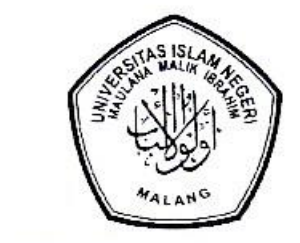

KEMENTERIAN AGAMA REPUBLIK INDONESIA

UNIVERSITAS ISLAM NEGERI MAULANA MALIK IBRAHIM MALANG

PASCASARJANA

Jalan Ir. Soekarno No. 34 Batu 65323, Telepon \& Fatimile (0. 11 , 5:11::

Website: http://pasca.uin-malang.ac.id, Email: ppsa uin-malang.ac.id

Nomor : B-029/Ps/HM.01/03/2018

07 Maret 2018

Hal : Permohonan Ijin Penelitian

Kepada

Yth. Kepala MA Umar Mas'ud.

$\mathrm{Di}$

Tempat

Assalamu'alaikum Wr.Wb

Berkenaan dengan tugas penulisan tesis bagi mahasiswa kami, maka dengan ini mohon kepada Bapak/Ibu untuk berkenan memberi ijin kepada mahasiswa di hawah ini melakukan penelitian pada lembaga yang Bapak/lbu pimpin:

Nama $\quad:$ Moh. Nasir

NIM : 16710016

Program Studi : Magister Manajemen Pendidikan Islam

Dosen Pembimbing : 1. Dr. H. Munirul Abidin, M.Ag.

2. Dr. H. Abdul Basith, M.Si.

Judul Tesis : Analisis Pengaruh Lingkungan Kerja dan Motivasi Kerja Terhadap Kepuasan Kerja Guru dan Dampaknya Pada Kinerja Guru Madrasah Aliyah di Pulau Bawean.

Demikian permohonan ini disampaikan, atas perkenan dan kerjasamanya disampaikan terima kasih

Wassalamu'alaikum Wr.Wb

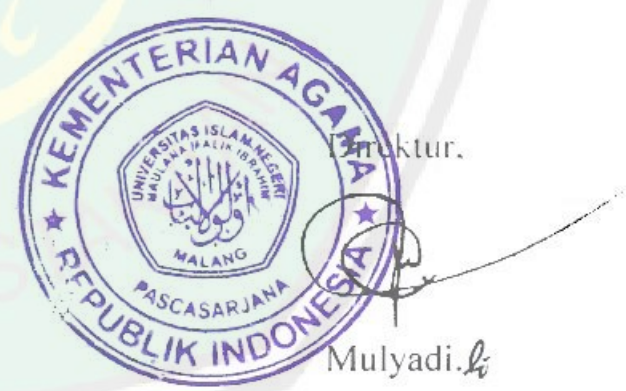




\section{YAYASAN PONDOK PESANTREN HASAN JUFRI MADRASAH ALIYAH HASAY JUFRI}

NSM : 131235250041 (Terakreditasi A) NPSN : 20500930

Program Studi: International Class Program - Ilmu Alam - Ilmu Sosial - Ilmu Agama

Alamat : Jl. Raya Kebunagung Lebak Sangkapura Bawean 61181 Telp. (0325) 421800

Email : mashasanjufri@gmail.com Website : www.hasanjufri.com

\section{SURAT KETERANGAN PENELITIAN}

Nomor : Ma.526/MA-HJ/PP.00.6/046/IV/2018

Yang bertandatangan di bawah ini Kepala MA Hasan Jufri Kebunagung Lebak Sangkapura Gresik, menerangkan bahwa :

Nama

: MOH. NASIR

NIM

$$
\text { : } 16710016
$$

Program Studi : Magister Manajemin Pendidikan Islam

Judul Tesis

: Analisis Pengaruh Linglungan Kerja dan Motivasi Kerja Terhadap Kepuasan Kerja Guru dan Dampaknya Pada Kinerja Guru Madrasah Aliyah di Pulau Bawean

Yang bersangkutan telah melakukan penelitian di MA Hasan Jufri Kebunagung Lebak Sangkapura Bawean Gresik.

Demikian surat keterangan ini dibuat agar dapat dipergunakan sebagaimana mestinya.

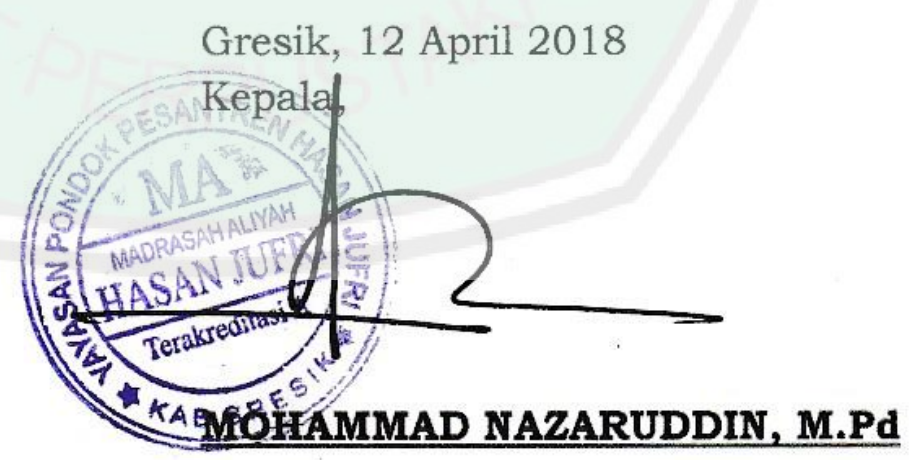




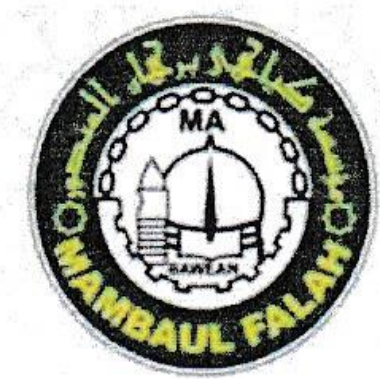

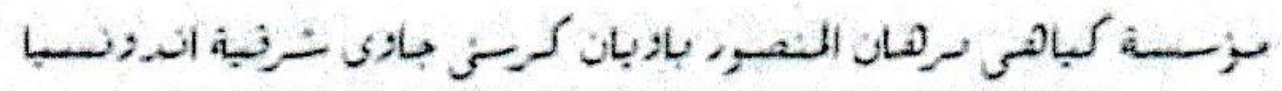
YAYASAN KYAI BURHAN AL-MANSUR MADRASAH ALIYAH "MAMBAUL FALAH" TERAKREDITASI A

NSM : 131235250049 - NPSN : 20580228

SK.MEN.KEH.NO. C-159.HT.03.02-TH.1993

Alamat: Tambilung Sukaoneng Kecamatan Tambak Bawean Kabupaten Gresik

Tolp. (0325) 421732, 411034, 411039 fax (0325) 411072 Jawn Timur Indonesia

\section{SURAT KETERANGAN}

Nomor : 0527/277 /SK.S/MA.MF/IV/2018

Yang bertanda tanda di bawah ini

$\mathrm{N}$ a m a

: ABDUL HARIS, S.Ag, MA

Alamat

: Tambilung Sukaoneng Kecamatan Tambak

Jabatan

: Kepala MA. Mambaul Falah Tambilung Tambak

Dengan ini menerangkan bahwa mahasiswi yang beridentitas :

Nama

: Moh. Nasir

NIM

: 16710016

Program Studi

: Magister Managemen Pendidikan Islam

Universitas

: Universitas Islam Negeri Maulana Malik Ibrahim

Malang

Telah selesai melakukan penelitian pada Guru MA. Mambaul Falah selama 2 (Dua) minggu, terhitung mulai tanggal 02 sampai dengan 14 April 2018 untuk memperoleh data dalam rangka penyusunan Tesis yang berjudul "Analisa Pengaruh Linkungan Kerja Dan Motivasi Kerja Terhadap Kepuasan Kerja Guru dan Dampaknya Pada Kinerja Guru Madrasah Aliyah di Pulua Bawean".

Demikian surat keterangan ini dibuat dan diberikan kepada yang bersangkutan untuk dipergunakan seperlunya.

BURHA

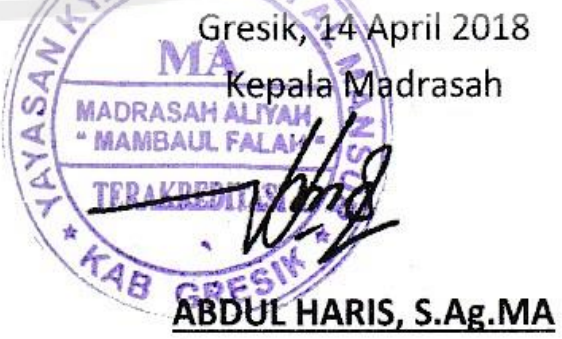




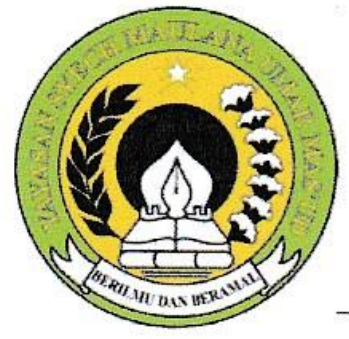

\section{YAYASAN SYECH MAUALANA UMAR MAS'UD MADRASAH ALIYAH "UMAR MAS'UD" NSM : 131235250040 (Terakreditasi B) NPSN : 20580246 \\ Alamat : Jl. Kawedanan No. 04 Sangkapura Bawean 61181 Telp. (0325) 424200 email : maummanur60@yahoo.com}

\section{SURAT KETERANGAN TELAH MELAKSANAKAN PENELITIAN \\ Nomor : 44/ Ket-05 / MA UMMA/IV/2018}

Yang bertanda tangan di bawah ini, Kepala Madrasah Aliyah Umar Mas’ud menerangkan bahwa :

Nama

Tempat Tanggal Lahir

NIM

Perguruan Tinggi

Program

Judul Skripsi
Moh. Nasir

Batam, 16 Juli 1993

16710016

Universitas Islam Negeri Maulana Malik Ibrahim

Magister Manajemen Pendidikan Islam

Analisis Pengaruh Lingkungan Kerja dan Motivasi Kerja

Terhadap Kepuasan Kerja Guru dan Dampaknya Pada Kinerja

Guru Madrasah Aliyah di Pulau Bawean

Mahasiswa tersebut di atas, telah melaksanakan Penelitian di Madrasah Aliyah Umar Mas'ud dari tanggal 2 April s/d 9 April 2018.

Demikian Surat Keterangan ini kami buat, untuk dipergunakan sebagaimana mestinya.

Sangkapura, 09 April 2018

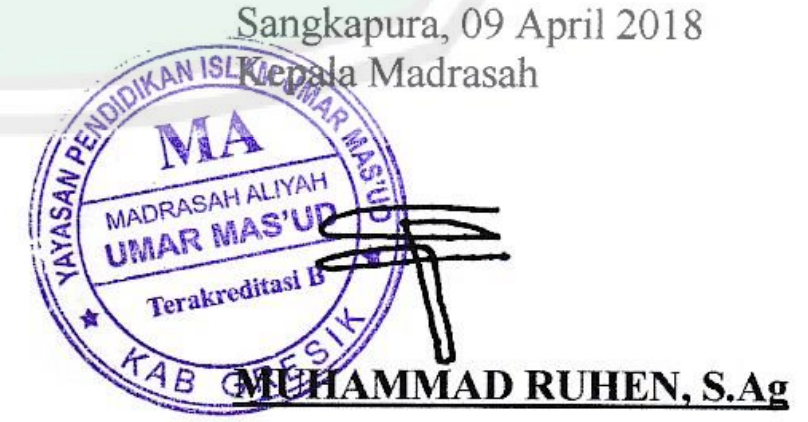




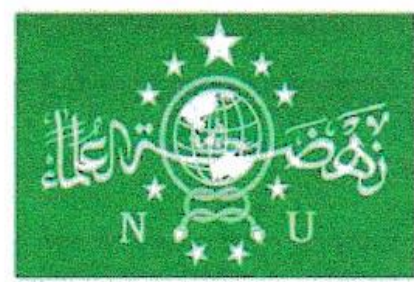

\section{LEMBAGA PENDIDIKAN MA'ARIF NU MADRASAH ALIYAH " MIFTAHUL HUDA " TAMBAK - GRESIK \\ BADAN HUKUM PERKUMPULAN NAHDLATUL ULAMA \\ NSM : 131235250051 \\ NPSN : 20580233 \\ "TERAKREDITASI " $\mathrm{B}$ "}

Alamat : JI. Raya Kepuhteluk No.01 Ds.Kepuhteluk Kec.Tambak Kab.Gresik 61182, No Telp (0325) 411588

\section{SURAT KETERANGAN}

Nomor : 046/10-516/MA.MIDA/ SK/IV/2018

Yang bertandatangan dibawah ini Kepala Madrasah Aliyah Miftahul Huda Kepuhteluk-TambakGresik menerangkan dengan sebenarnya :

Nama
NIM
Program Study
Judul Tesis

: Moh. Nasir

$: 16170016$

: Magister Manajemen Pendidikan Islam

: Analisis Pengaruh Lingkungan Kerja dan Motivasi Kerja Terhadap Kepuasan Kerja Guru dan Dampaknya pada Kinerja Guru Madrasah Aliyah di Pulau Bawean

Bahwa Mahasiswa tersebut diatas benar-benar telah melakukan dan menyelasaikan Penelitian di MA. Miftahul Huda Kepuhteluk -Tambak- Gresik.

Demikian surat keterangan ini dibuat dengan sebenarnya dan agar digunakan sebagaimana mestinya

Kepuhteluk, 17 April 2018

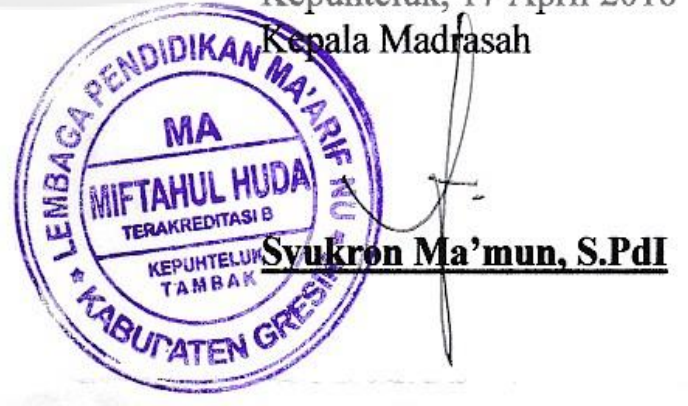

